EFFECTS OF EFFLUENTS FROM A COAL-FIRED, ELECTRIC-GENERATING

POWERPLANT ON LOCAL GROUND WATER NEAR HAYDEN, COLORADO

By Sherman R. Ellis and Phyllis G. Mann

U.S. GEOLOGICAL SURVEY

Water-Resources Investigations

Open-File Report 81-1196

Prepared for the

U.S. ENVIRONMENTAL PROTECTION AGENCY

Lakewood, Colorado

1982 
UNITED STATES DEPARTMENT OF THE INTERIOR

JAMES G. WATT, Secretary

GEOLOGICAL SURVEY

Dallas L. Peck, Director

For additional information write to:

Colorado District Chief U.S. Geological Survey, MS 415 Box 25046, Denver Federal Center Lakewood, CO 80225 


\section{CONTENTS}

Page

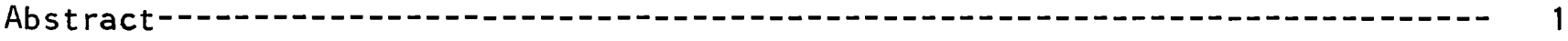

Introduction---------

Objectives---

Acknowl edgments---0-

Plant operation---0.-

Geohydrologic setting--

Data-collection network--

Ponds---1--

Wells---on-

Seeps---

Discharge weir--10-0 19

Streams---------

Ambient ground water---0

Hayden powerplant effluent----

Effects of boron----

Effects of effluents-

Ponds---1---on

Wells---on- 31

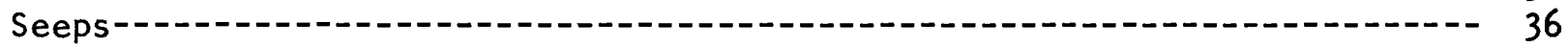

Discharge weir----1-

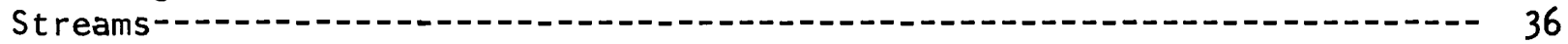

Ground-water movement and quantity--

Conclusions------

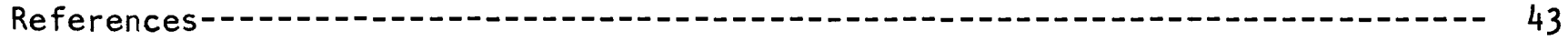

Systems of locating and numbering wells and springs---

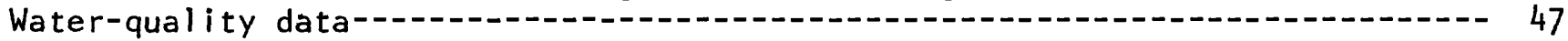

\section{LLUSTRATIONS}

Plates 1-7. Maps showing:

1. Location of ponds, wells, seeps, discharge weir, streams, and general features at the Hayden powerplant, Hayden, Colorado-- In pocket

2. Altitude of the top of the Lewis Shale at the Hayden powerplant, Hayden, Colorado-... In pocket

3. Water table at the Hayden powerplant, Hayden, Colorado, December 1978--... In pocket

4. Water table at the Hayden powerplant, Hayden, Colorado, June 1979- In pocket

5. Water table at the Hayden powerplant, Hayden, Colorado, October 1979

6. Water table and direction of ground-water flow at the Hayden powerplant, Hayden, Colorado, March 1979---- In pocket

7. Saturated thickness of the aquifer at the Hayden powerplant, Hayden, Colorado, March 1979-...- In pocket 


\section{CONTENTS}

Figure 1. Index map showing location of the Hayden powerplant and local features-.-...-

2. Schematic diagram showing preliminary water budget of the Hayden powerplant--

3-10. Graphs showing:

3. Monthly precipitation and evaporation at the Hayden powerplant--

4. Water-level fluctuations in the intermediate-quality and the evaporation ponds, October 1978 to January 1980-..

5. Water-level fluctuations in well is HS-3, HS-4, HS-5, HS-6, $\mathrm{HS}-7$, HS-9, FC-2, and FC-3-- 17

6. Water-level fluctuations in wells HS-14, HS-16, and HS-17---- 18

7. Values of specific conductance and boron for selected ponds-- 29

8. Values of specific conductance and boron for selected wells-- 32

9. Values of specific conductance and boron for selected wells-- 33

10. Values of specific conductance and boron for selected seeps-- 37

11. Diagram showing system of locating and numbering wells and springs- 45

TABLES

Page

Table 1. Water-quality standards for water use in Colorado-

2. Data on test wells drilled at the Hayden powerplant-16

3. Relative tolerance of plants to boron- 23

4. Permissible limits for concentrations of boron in several classes of irrigation water-... 23

5. Average concentrations of selected trace elements in water from ponds, seeps, streams, and the discharge weir and the percentages as compared to the concentrations of the same elements in the ambient ground water-... 25

6. Number of samples of water from ponds, seeps, streams, and the discharge weir analyzed for boron and manganese compared with the number of samples exceeding the Colorado Department of Health (1977b) standards for agricultural use of water-...

7. Average concentrations of selected trace elements in water from wells and the percentages as compared to concentrations of the same elements in the ambient ground water--

8. Number of water samples analyzed for boron and manganese compared with the number of samples exceeding Colorado Department of Health (1977b) standards for agricultural use of water from wells--.-.-- 


\section{METRIC CONVERSION FACTORS}

Inch-pound units used in this report may be converted to metric SI (International system) units by using the following conversion factors:

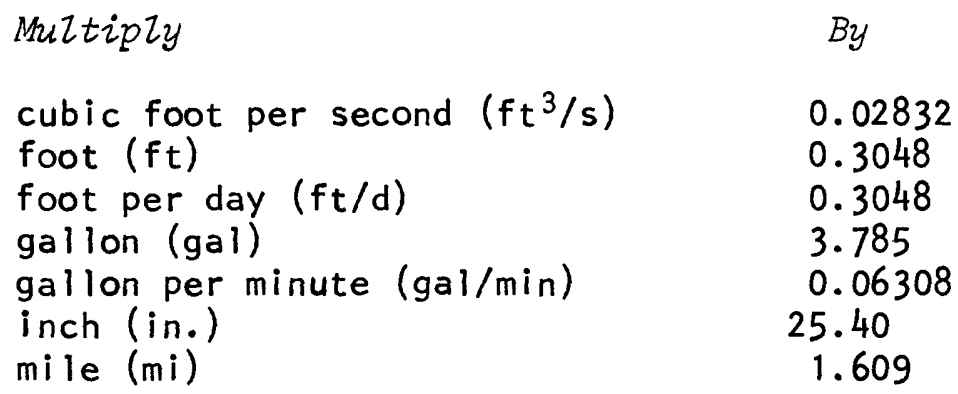

0.3048

gallon (gal)

3.785

0.06308

gallon per minute (gal/min)

inch (in.)

$\mathrm{mile}(\mathrm{mi})$

1.609

cubic meter per second meter

meter per day

liter

liter per second

millimeter

ki lometer

National Geodetic Vertical Datum of 1929 (NGVD of 1929): A geodetic datum derived from a general adjustment of the first-order level nets of both the United States and Canada, formerly called "Mean Sea Level." NGVD of 1929 is referred to as sea level in this report. 



\title{
EFFECTS OF EFFLUENTS FROM A COAL-FIRED, ELECTRIC-GENERATING POWERPLANT ON LOCAL GROUND WATER NEAR HAYDEN, COLORADO
}

By Sherman R. Ellis and Phyllis G. Mann

\begin{abstract}
Data were collected at the Hayden powerplant in northwest Colorado for about a year during 1978-79 to monitor the effects of effluent and raw-water storage ponds on the local ground water, Sage Creek, and the Yampa River. Ground water downgradient from the effluent ponds had average boron concentrations in excess of the Colorado Department of Health standard for agricultural use of water. The water from seeps located downgradient from the powerplant is probably the best indicator of downgradient water quality and had average concentrations of boron two times that of the Colorado Department of Health standard for agricultural use of water.
\end{abstract}

The Hayden powerplant uses seven principal ponds for the storage and disposal of effluents and raw water: An evaporation pond, an "intermediate-quality" pond, an "oil-skimmer" pond, a "high-quality" pond, two raw-water storage ponds, and a coal-pile runoff pond. Two theories may be used to explain the high boron content and high specific conductance of the water from wells and seeps downgradient from the evaporation, the intermediate-quality, the oil-skimmer, and the high-quality ponds. One theory is that all of the ponds are leaking; the other theory, suggested by Hayden powerplant personnel, is that a plume of ground water having high concentrations of boron and high values of specific conductance is responsible. This plume is the remnant of a plume resulting from the leakage of a fly-ash storage pond, which was converted to a raw-water storage pond in 1976 . The data support the theory that the ponds are leaking or a combination of leaking ponds and the vestigial plume theory. The theory that a vestigial plume is responsible for the high boron content and high specific conductance of the water cannot be refuted.

It is estimated that about one-fourth of the flow past a representative cross section downgradient from the evaporation pond is leakage from the pond, and about three-fourths of the flow past a representative cross section downgradient from the intermediate-quality, the oil-skimmer, and the high-quality ponds is leakage from these ponds. Estimates of the amount of leakage from the ponds are based on the assumption that the ponds are the only sources of water high in boron. 
Chemical analyses of water from wells and a ground-water discharge weir downgradient from the raw-water storage ponds indicate these ponds are leaking. The effect of this leakage is that the ground water downgradient from these ponds has a lower specific conductance and a lower boron concentration than the ambient ground water. The concentration of trace elements in the water from the wells and the discharge weir generally declined during the study, probably because of the decreasing effects of a plume from the raw-water pond previously used for fly-ash disposal.

The effluents from the Hayden powerplant lowered the specific conductance and the iron and manganese concentrations, increased boron concentration, and had little or no effect on the selenium concentration in Sage Creek. Sage Creek and the effluent from the Hayden powerplant had no discernible effect on the Yampa River because the volume of water in the Yampa River was so much greater than the volume of water in Sage Creek and the effluent from the powerplant.

\section{INTRODUCT ION}

As of December 31, 1978, Colorado had 4,067.5 megawatts of electricgenerating capacity. of this capacity, about 76 percent was generated by the combustion of coal. In Colorado, the use of coal for generating electricity is expected to increase in the future as supplies of oil and natural gas decrease.

Associated with coal-fired, electric-generating plants are various environmental concerns, including fly ash, emissions from boilers, and effluents. The effluents, which include brines from water concentrators, cooling-tower blowdown water, and water that has been in contact with fly or bottom ash, commonly contain large concentrations of certain chemical constituents, including boron (Phung and others, 1979; Holland and Jones, 1978; and M. A. Hardy, U.S. Geological Survey, written commun., 1980). Evaporation ponds commonly are used to dispose of effluents; however, the effects of these ponds on the local ground water are not fully understood. Such an understanding is essential for the design of adequate effluent-disposal facilities at coal-fired, electric-generating plants.

The Hayden powerplant, located near the town of Hayden in northwest Colorado (fig. 1), owned and operated by the Colorado-Ute Electric Association, Inc., was selected as a site to study the effects of a coal-fired, electric-generating plant on the local ground water. Prior to April 30, 1976, effluents from the Hayden powerplant were discharged into Sage Creek, a tributary to the Yampa River. On April 30, 1976, discharge of effluents into Sage Creek ceased and effluents then were discharged into an evaporation pond. Studies done as part of the Yampa River basin assessment (J. W. Warner, U.S. Geological Survey, oral commun., 1980) indicated that ground water is discharging to the Yampa River in this area. Any water seeping from these ponds could possibly affect the quality and quantity of the local ground water. Thus, the ground water eventually could affect the water quality of the Yampa River. 


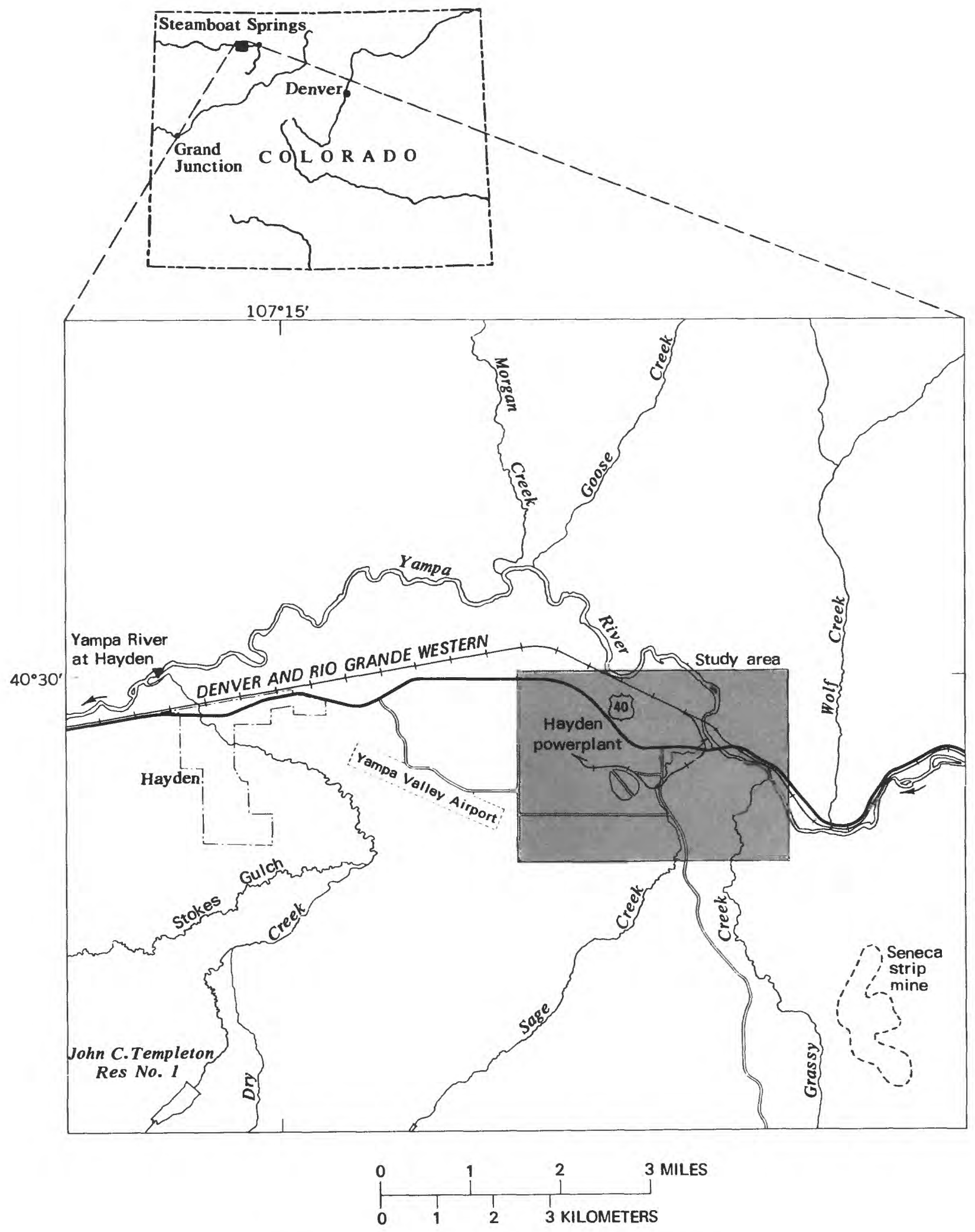

Figure 1.-- Hayden powerplant and local features. 


\section{Objectives}

This study, which began in August 1978, was conducted by the U.S. Geological Survey for the U.S. Environmental Protection Agency. The objectives of the study were to: (1) Determine the ambient ground-water quality near the powerplant; (2) document the quality and quantity of effluents from the powerplant; (3) document the effect of boron on the ground water; and (4) determine the effects of the powerplant effluents on ground-water quality, quantity, and movement. The data and interpretation of data in this report may assist local agency planners, powerplant personnel, and designers to evaluate the effects of a coal-fired, electricgenerating plant in semiarid areas with similar hydrology if the method of disposal of effluents is the same as the method used at the Hayden powerplant.

\section{Acknowledgments}

Appreciation is extended to Robert Heard, Environmental Field Supervisor, Hayden powerplant, for assistance in providing data on plant operations and in collecting data during the winter months. Colorado-Ute Electric Association, Inc., provided access to their property, permission to drill observation wells, and data on the plant site and land operation. F. R. Carpenter provided access to his property adjoining the Hayden powerplant and permission to drill observation wells on his property.

\section{PLANT OPERATION}

Construction of the Hayden powerplant began in April 1963. The first generator was placed in operation July 1, 1965, and a secolid generator was placed in operation September 1, 1976. The net generating capacity of the plant is about 450 megawatts. About 15 megawatts additional power is used in internal plant operations. About 5,000 tons of coal per day is supplied to the plant by the Seneca Mine (fig. 1), a strip mine located about $4 \mathrm{mi}$ to the southeast.

The Hayden powerplant obtains its water supply from the Yampa River and has water rights for about $30 \mathrm{ft}^{3} / \mathrm{s}$. The location. of the intake pumping station is shown on plate 1. Preliminary data supplied by the powerplant operators indicate that an average of $9 \mathrm{ft}^{3} / \mathrm{s}$ is diverted from the Yampa River. Prior to November 1978, a single water-storage pond (raw-water storage pond no. 1) was used. A second pond (raw-water storage pond no. 2), used as a fly-ash disposal pond from 1965 to December 1974, was cleared of fly ash, lined with a 5-ft layer of locally obtained clay, and placed in operation as a water-storage pond during November 1978.

Prior to April 30, 1976, the plant discharged effluent into Sage Creek. in order to cease discharging effluents into Sage Creek, four principal ponds were built to the north of the plant. The ponds included an evaporation, an "intermediate-quality," a "high-quality," and an "oil-skimmer" pond (pl . 1). Construction of the ponds was started in late 1975, and they were placed in operation in April 1976. These ponds were 1 ined with a 2-ft layer of locally obtained clay. 
Two runoff-retention ponds $(p l$. 1) were constructed to retain surface runoff from the plant. Runoff-retention pond no. 1, located in a natural gully, receives local runoff from the northwest part of the powerplant. Runoff-retention pond no. 2 receives runoff via a small canal from the west side of the powerplant, where a scrap storage yard is located. The ponds are usually dry from late summer through winter and contain water only during the spring or early summer when surface runoff is above average. The runoff may be from either rainfall or snowmelt.

A preliminary water budget obtained from the Hayden powerplant operators is depicted in figure 2. This budget is based on older measurements that could not be updated or verified during this study because the flow gages in the control center had been rendered inoperable by a water overflow. It is known that about $9 \mathrm{ft}^{3} / \mathrm{s}--$ not $6.28 \mathrm{ft}^{3} / \mathrm{s}--$ of water is being withdrawn from the Yampa River and that $0.07 \mathrm{ft}^{3} / \mathrm{s}$ of effluent is being discharged into the evaporation pond (Colorado-Ute Electric Association, Inc., oral commun., 1980). Although the budget is not up to date, the diagram approximates the relative flow rates of the water used in the powerplant.

A subsurface drainage system, formerly used to discharge effluent into Sage Creek, discharges ground water into Sage Creek. This system, referred to as the discharge weir in this report, is depicted on plate 1 as a 30-in. reinforced concrete pipe (RCP) drain ending in a discharge weir. Visual inspection of the system indicates that ground water seeps into the pipes and is present from a point opposite well HS-15 to the discharge weir at the mouth of the pipe. At present (1980), the only water discharged into the pipe system is ground water. The system probably is collecting water that has infiltrated from the raw-water storage ponds, the coal-storage and runoff-pond area, and local ground water.

An important part of the plant operation is the evaporation of wastewater from the evaporation pond. Two studies were conducted to determine the evaporation rates. The first study was conducted by a consulting firm before the pond became operational, and the second study was conducted by Hayden powerplant personnel in 1979. Both studies concluded that about $32 \mathrm{in}$. are evaporated each year; the average precipitation at Hayden is about $15 \mathrm{in.}$. per year, resulting in a net evaporation of about $17 \mathrm{in}$. per year (Hayden powerplant personnel, written commun., 1980). The studies also determined that most evaporation occurs from June through September, and little or no evaporation occurs during the remainder of the year (fig. 3) due to ice cover of the ponds.

\section{GEOHYDROLOGIC SETTING}

The Hayden powerplant is located on an alluvial terrace, which is approximately $100 \mathrm{ft}$ above the present flood plain of the Yampa River. This terrace, lowest of several alluvial terrace remnants which were formed by the downcutting of the Yampa River, extends about $4 \mathrm{mi}$ to the south of the plant. Underlying the alluvium terrace is the Lewis Shale of Late Cretaceous age, a relatively impermeable formation that inhibits ground-water movement ( $\mathrm{pl}$. 2). 


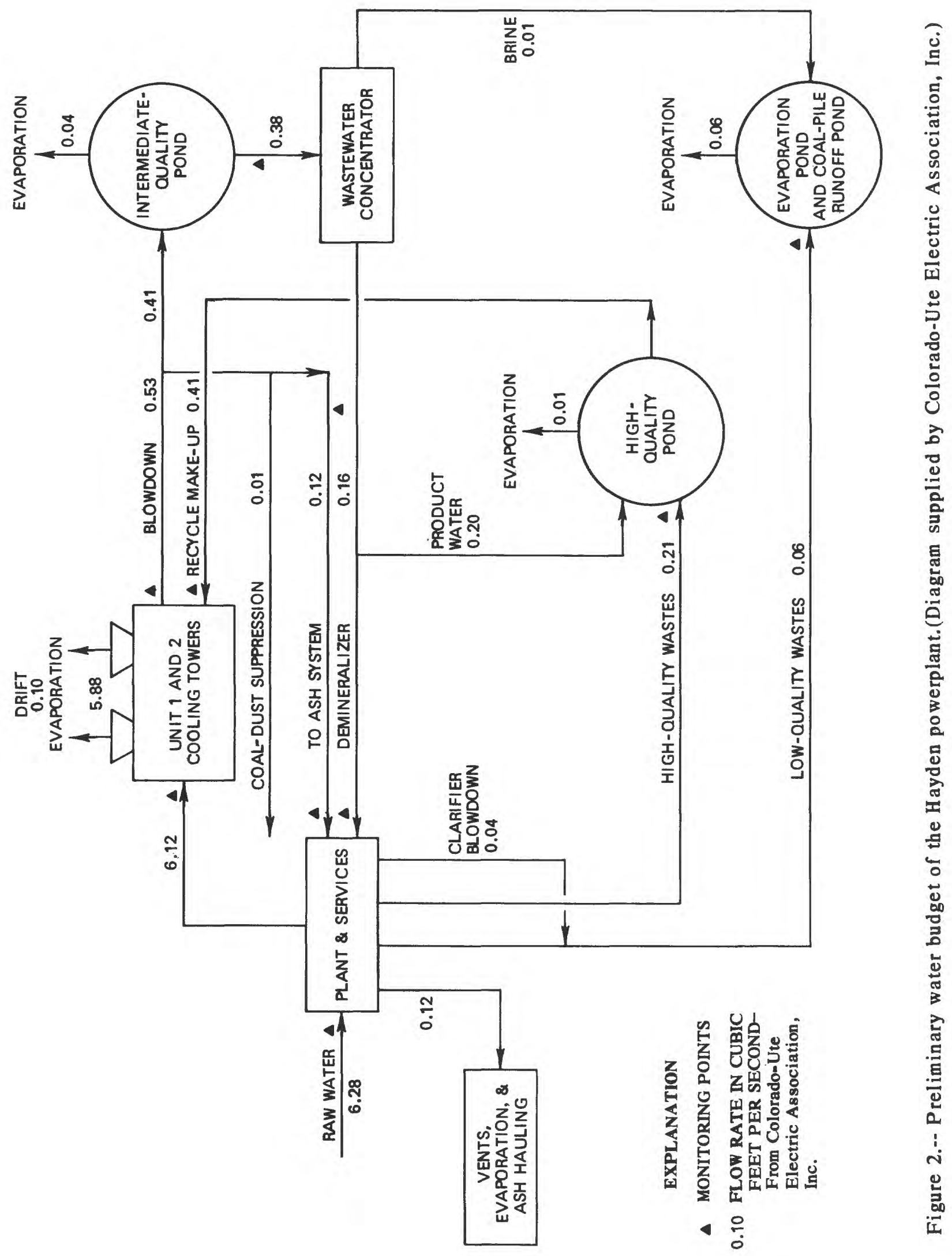




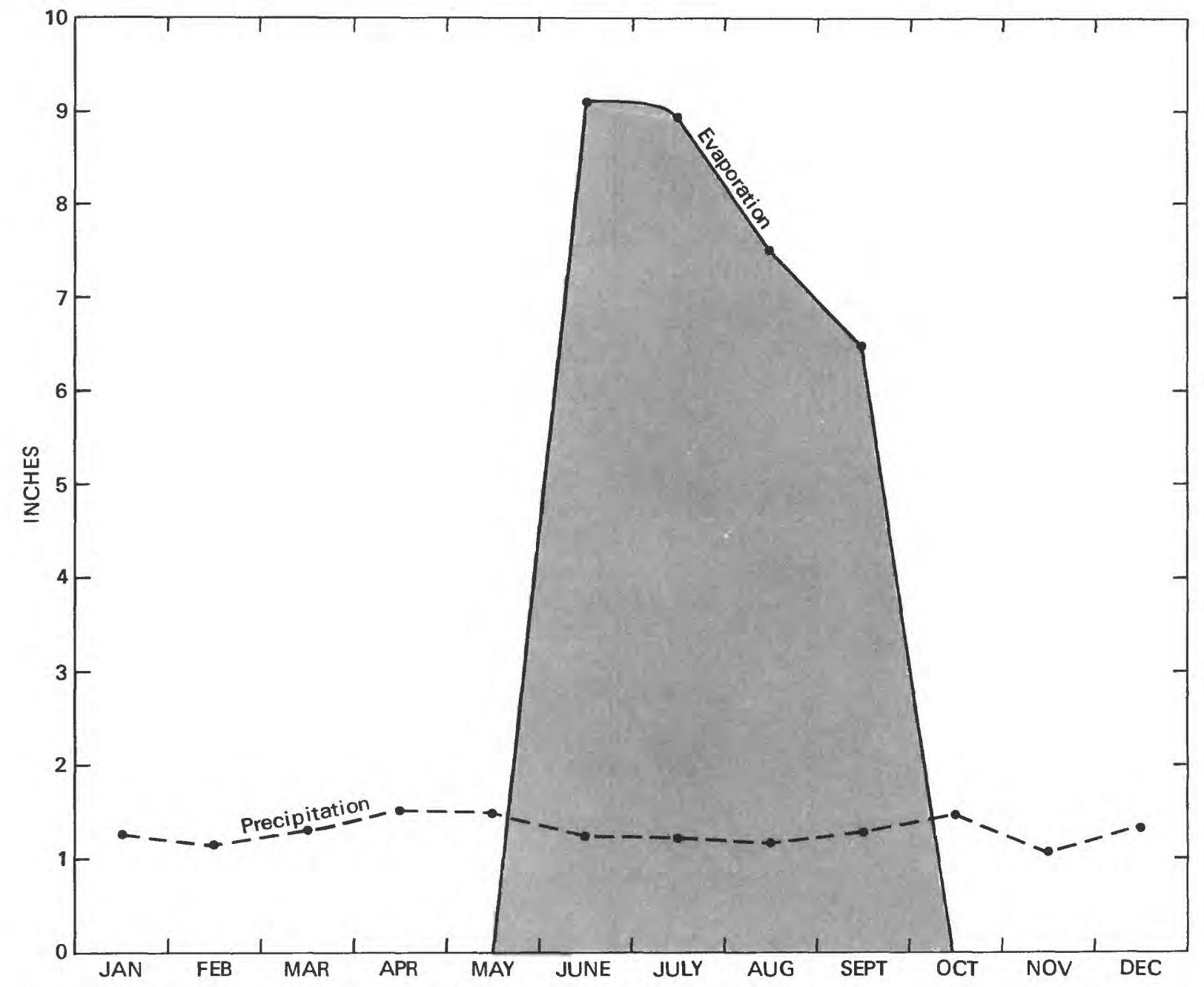

Figure 3.-- Monthly precipitation and evaporation at the Hayden powerplant. (From Colorado-Ute Electric Association, Inc.) 
The terrace deposit is about 27 to $49 \mathrm{ft}$ thick in the study area. The deposit is composed of alluvial sand and gravel and includes scattered thin layers of clay, caliche, and boulders. This alluvium supplies all of the well water because the Lewis Shale is not an aquifer in this area. Wells in the alluvium are used primarily for domestic purposes and yield less than $20 \mathrm{gal} / \mathrm{min}$.

Seeps (pl. 1) may issue from the base of the alluvium where the stream has cut down into the Lewis Shale. Several seeps are present along the north and east faces of the terrace within $300 \mathrm{ft}$ of the plant site. These seeps usually flow year round, but some go dry in late fall and winter. Information supplied by Hayden powerplant personnel and local residents indicates that the seeps were present prior to construction of the powerplant. However, residents claim that the discharge of the seeps has increased since the powerplant began storing effluents and Yampa River water in ponds.

\section{DATA-COLLECTION NETWORK}

\section{Ponds}

The Hayden powerplant uses seven principal ponds for the storage and disposal of effluents and raw water: The evaporation pond, the intermediate-quality pond, the oil-skimmer pond, the high-quality pond, raw-water storage ponds no. 1 and no. 2, and the coal-pile runoff pond. The evaporation pond is used for the storage of wastewater until it is evaporated. The evaporation pond receives wastewater from two sources--low-quality wastes from the powerplant and brine from the wastewater concentrator. The intermediate-quality pond receives blowdown water from the cooling towers and stores the water until it is recycled through the wastewater concentrator for reuse in the powerplant. The oil-skimmer pond is a small pond used to remove floating oil and grease from high-quality wastewater from the powerplant and high-quality water from the wastewater concentrator. The water from the oil-skimmer pond flows into the high-quality pond. The high-quality pond stores makeup water for use in cooling towers. The raw-water ponds store Yampa River water for use in the powerplant. The coal-pile runoff pond receives water only from precipitation and from runoff from the coal pile. The coal-pile runoff pond stores the water until it is evaporated. The location and interrelationship of these ponds are shown in figure 2 and on plate 1, except for the oil-skimmer pond, which is not shown in figure 2 .

Powerplant personnel make weekly measurements of stage in the evaporation, the intermediate-quality, and the high-quality ponds. The fluctuations in water levels in the intermediate-quality and the evaporation ponds from October 1978 to January 1980 are illustrated in figure 4. The oil-skimmer and the high-quality ponds are connected by an underground pipe and therefore are at the same elevation. The stage of the high-quality pond was not measured during the winter when the pond was frozen. Because the intermediate- and the high-quality ponds are at about the same elevation, water-level data on the high-quality pond are not presented here, but are available at the Hayden powerplant. 


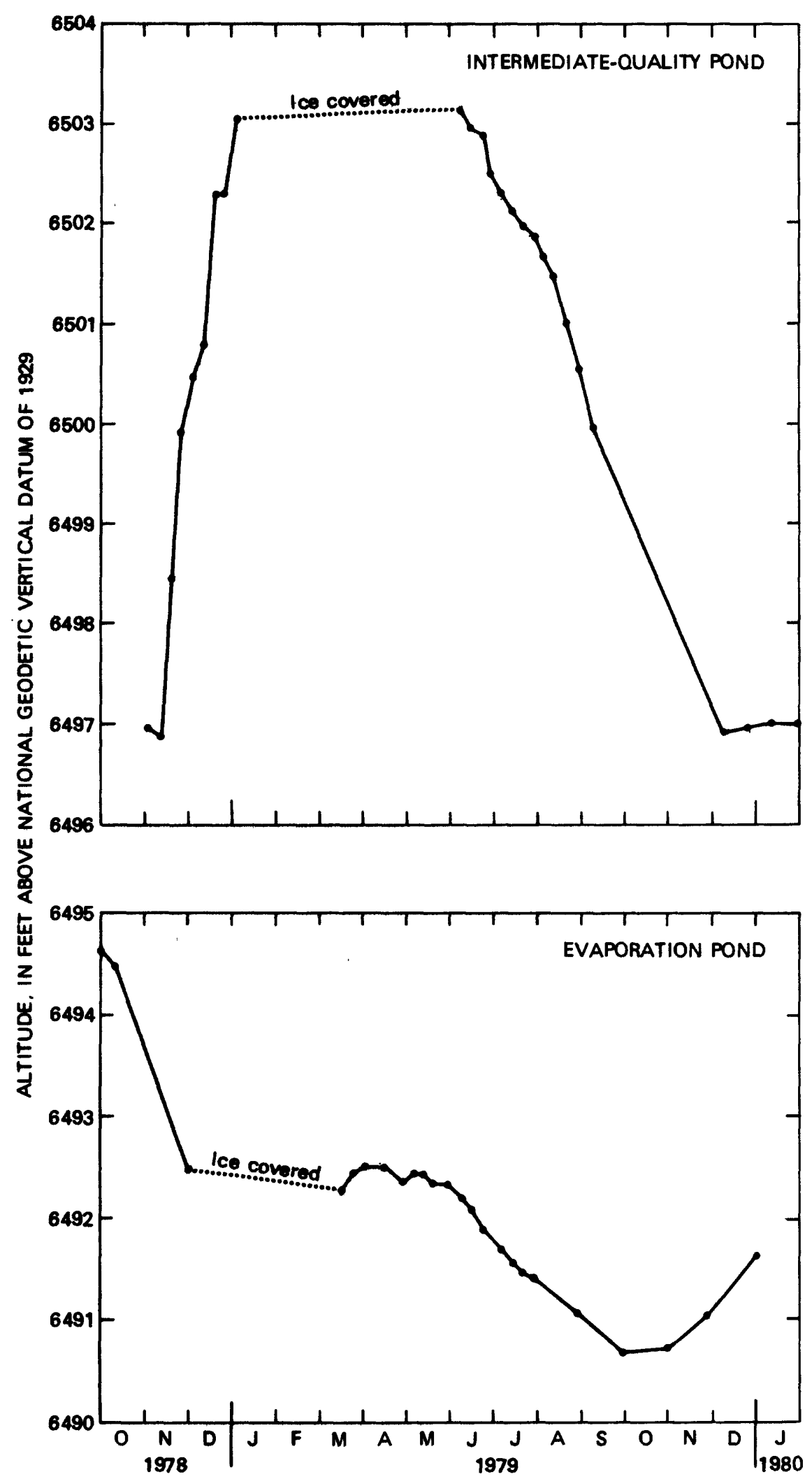

Figure 4.-- Water-level fluctuations in the intermediate-quality and the evaporation ponds, October 1978 to J anuary 1980 . 
Water-quality samples were collected quarterly from December 1978 through October 1979 from all ponds except raw-water storage pond no. 2, which has the same source of water as raw-water storage pond no. 1 . The initial samples were analyzed for a fairly complete set of trace elements and common constituents. The number of trace-element analyses was later reduced to include only those constituents whose concentrations tended to exceed the Colorado Department of Health (1977b) water-quality standards or were of local interest. The Colorado Department of Health (1977b) standards for uses of water are listed in table 1. The trace-element analyses subsequently performed included: Boron, iron, manganese, selenium, and zinc. Only two analyses for common constituents were made on water from the ponds. Results of all of the analyses are presented in the section on Water-Qual ity Data.

\section{Wells}

In order to determine any effects that effluents from the powerplant might have on the shallow ground water, 22 test wells were drilled near the plant ( $p l .1$ and table 2). Well HS-14 was drilled to provide information on the ambient ground water. Well HS-14 and one privately owned well completed in the alluvium, the Barnes well, were used as controls in the study. Well HS-14 and the Barnes well are not directly upgradient from the principal direction of natural ground-water flow beneath the plant, but lie to the west of the ground-water flow. Water in the wells is assumed to represent the ambient ground water because both wells receive water from the same alluvial fill as that upgradient from the powerplant. The other 21 wells were drilled downgradient from the plant and its storage ponds. The downgradient wells were used to monitor the effects of the plant and ponds on the quality and quantity of ground water.

Well HS-17 was found to have been drilled in an old spoils dump left over from plant construction. Although well HS-17 could not be used to monitor the effect of effluents from the plant, the analyses of water from the well did provide information on the influence of the dump on the local ground water. This well and the dump are not upgradient from any other monitoring well.

All 22 wells were drilled without fluids using a diesel hammer, reverse-air circulation Becker ${ }^{l}$ drill. Each well was drilled through the alluvium 0.5 to $2 \mathrm{ft}$ into the Lewis Shale. The wells then were cased with $3.25-i n$. outside diameter PVC pipe. The lower end of the casing was capped and the lowest 10 to $20 \mathrm{ft}$ perforated. The wells were backfilled with gravel from the same alluvium in which they were completed. Each well was then sealed with cement and capped to prevent contamination from surface water. Levels were run for each well to determine the altitude above sea level.

${ }^{1}$ The use of the brand name in this report is for identification purposes only and does not imply endorsement by the U.S. Geological Survey. 
Water levels in all wells except the Barnes well were monitored for a year, from December 1978 through November 1979. The Barnes well has no access for measurement. Water levels were measured monthly to identify changes due to seasonal fluctuations, such as recharge from snowmelt and rainfall, pumpage from the aquifer, and the effects of lower pond levels. The water-level measurements are shown in table 2, and the water-level fluctuations in selected wells are illustrated in figures 5 and 6 . Water-level contours at times of low-, medium-, and high-water levels are shown on plates 3,4 , and 5 . The water-level contours tend to follow the outline of the evaporation, the intermediate-quality, and the oil-skimmer ponds, indicating a high ground-water level under these ponds. The shape of the water-level contours indicates the ponds are leaking, resulting in the elevated ground-water levels near the ponds.

Ground-water-quality data were collected quarterly from the test wells from December 1978 to October 1979. In addition, the Barnes well was sampled in June and October. Data from the Barnes well supplemented data from well HS-14 by providing additional information on the ambient ground-water quality. The initial samples were analyzed for a comprehensive set of trace elements and common constituents. The number of subsequent trace-element analyses was reduced to include only those constituents which exceeded the Colorado Department of Health (1977b) standards (table 1) or were of local interest. The trace elements analyzed for subsequent samples were: Boron, iron, manganese, selenium, and zinc. Two analyses for common constituents were made on the water from all wells, except the Barnes well, which had one analysis for common constituents made on the water from the well. Results of all these analyses are presented in the Water-Quality Data section.

\section{Seeps}

Seeps are present in the terrace cut along the north and east sides of the Hayden powerplant ( 1.1$)$. Seeps occur for about three-quarters of a mile along the north face of the terrace. Eight representative seeps were chosen for waterquality sampling. All seeps except seep HS-8 are perennial. The seeps were developed by clearing the immediate area of vegetation, enlarging the outflow, and digging collection basins which were drained and allowed to refill prior to sampling. Estimates of flow were made prior to each sampling; these estimates were either visual or based on the time required to fill a given volume. The estimates may be in error because the seeps extend laterally.

Water-quality samples were collected from seeps HS-1 through HS-4 and the gravel-pit seep from January through October 1979 on a quarterly basis. Samples from seeps HS-5 through HS-7 were collected quarterly from March through 0ctober 1979, and samples from seep HS-8 were collected in March and June. Seep HS -8 was dry in October. The January samples were analyzed for nearly all trace elements, but subsequent analyses included only boron, iron, manganese, selenium, and zinc. The common constituents were analyzed during the January and March samplings and then discontinued. Results of the analyses and data on flow are presented in the Water-Quality Data section. 


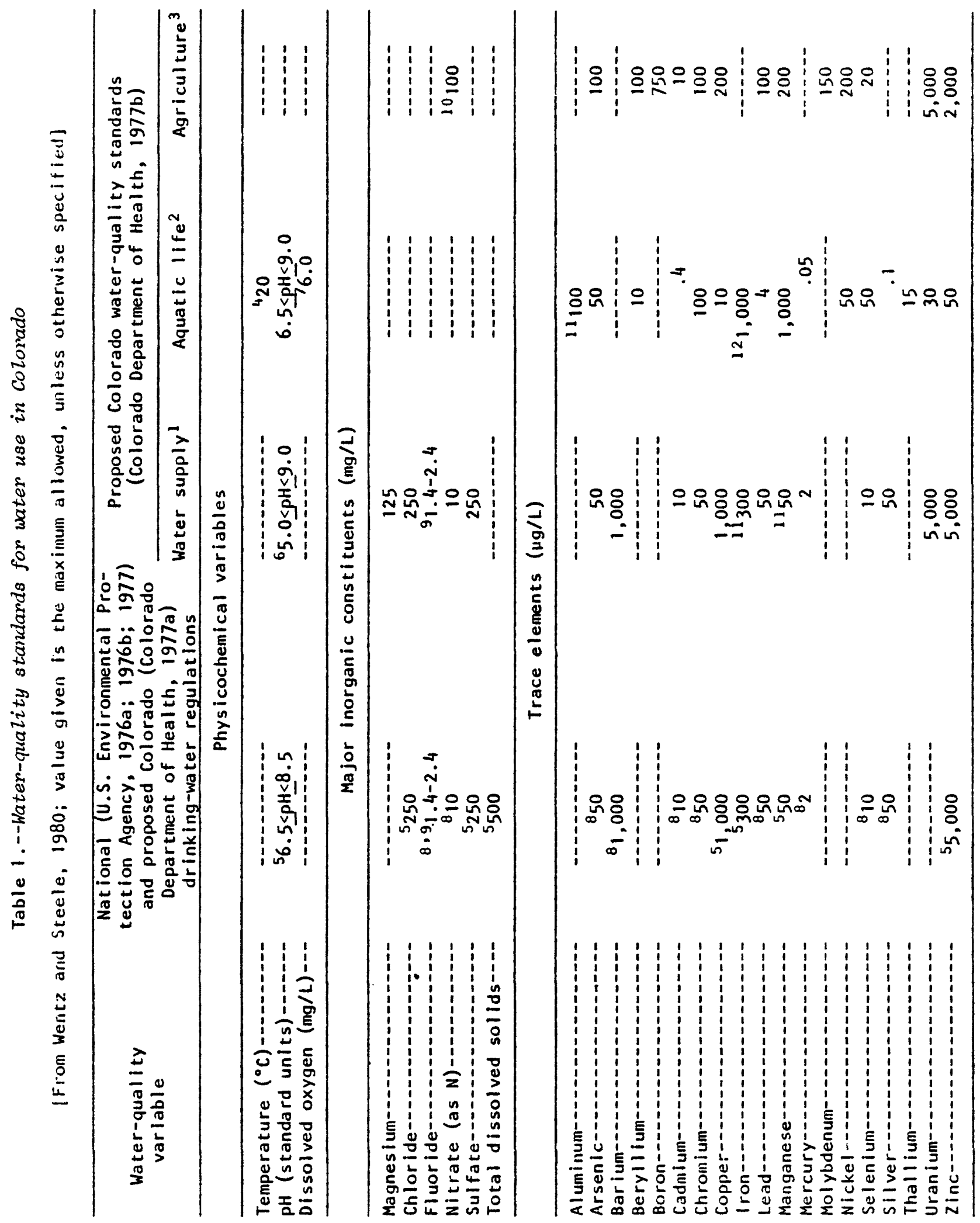




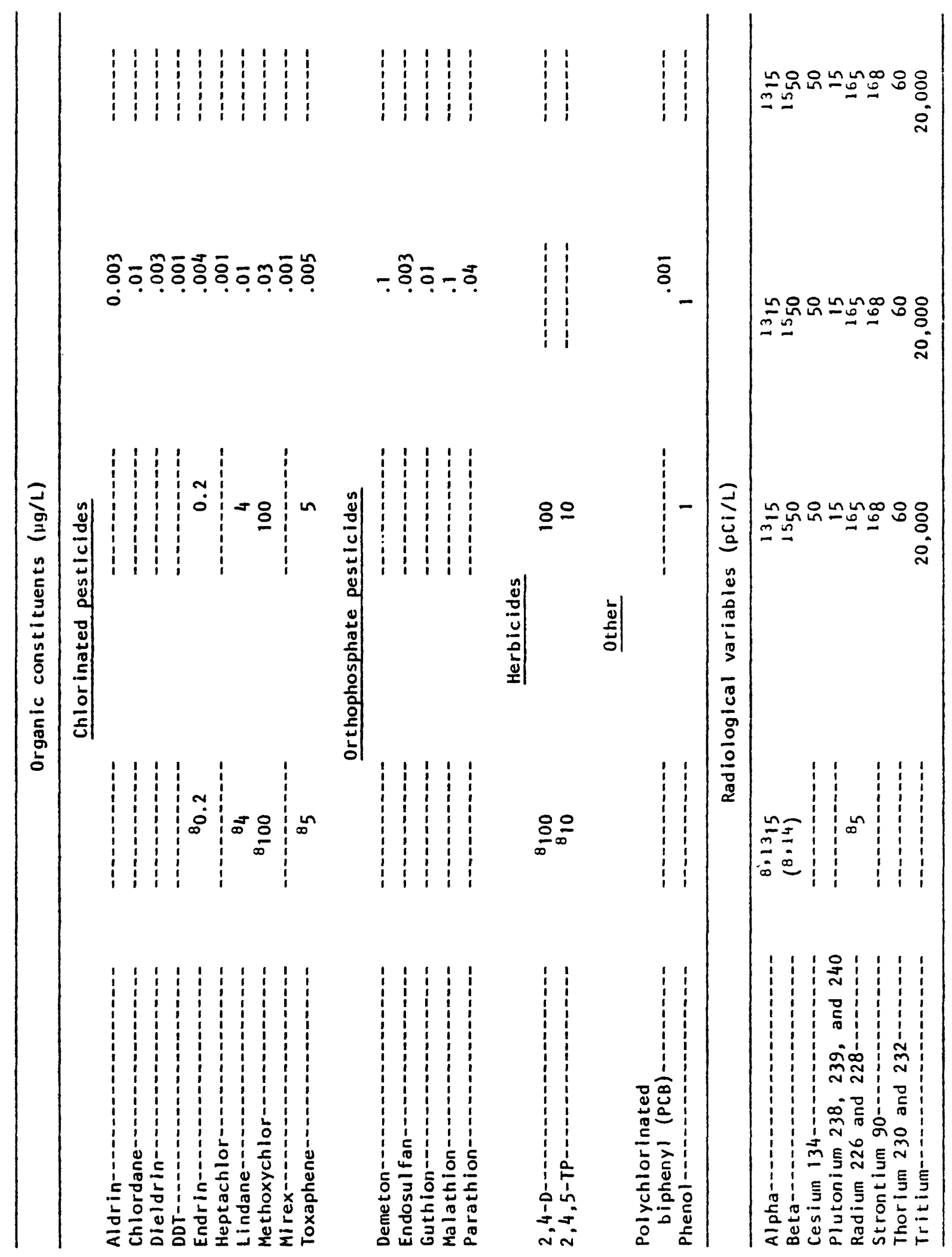




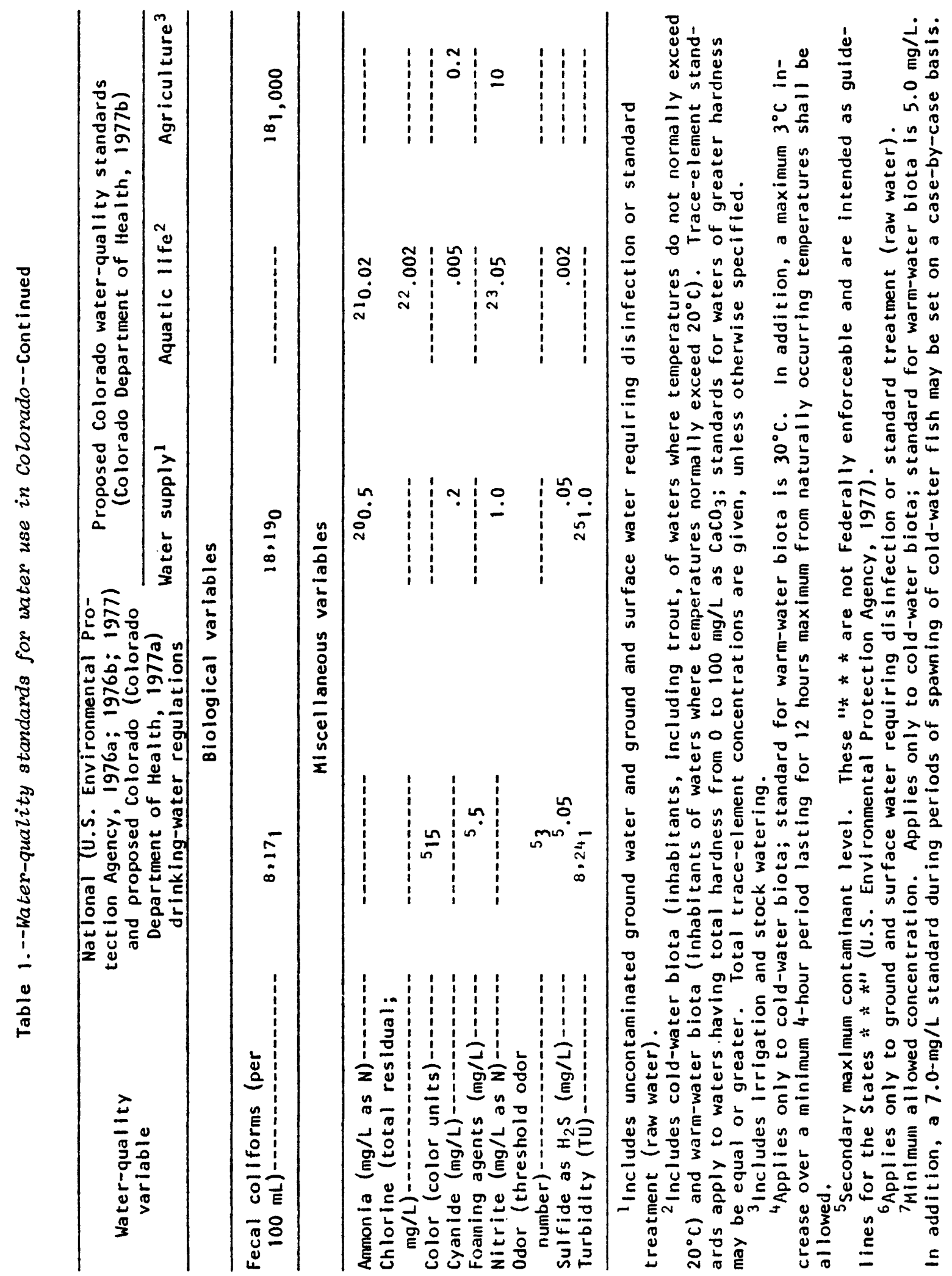




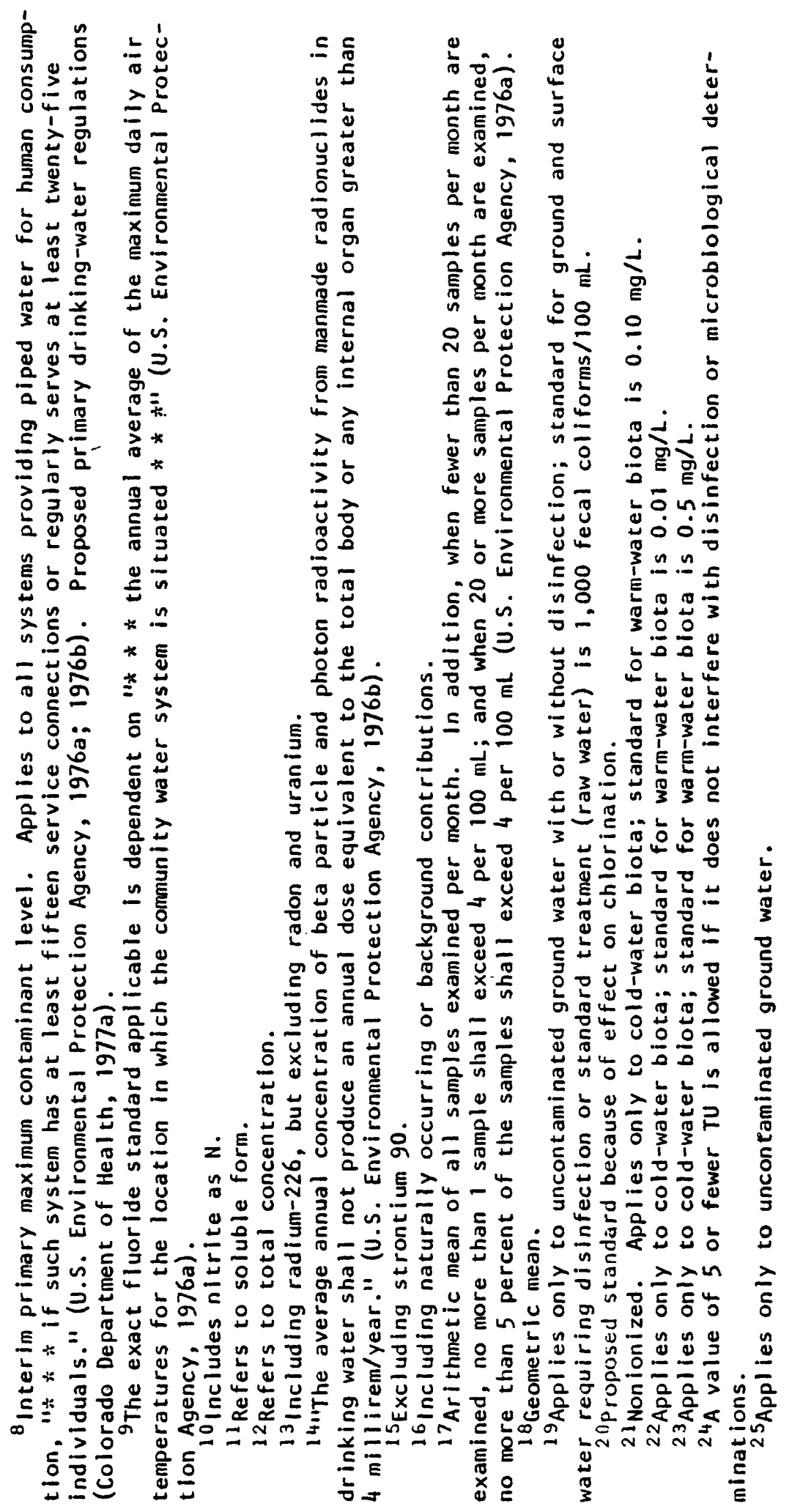




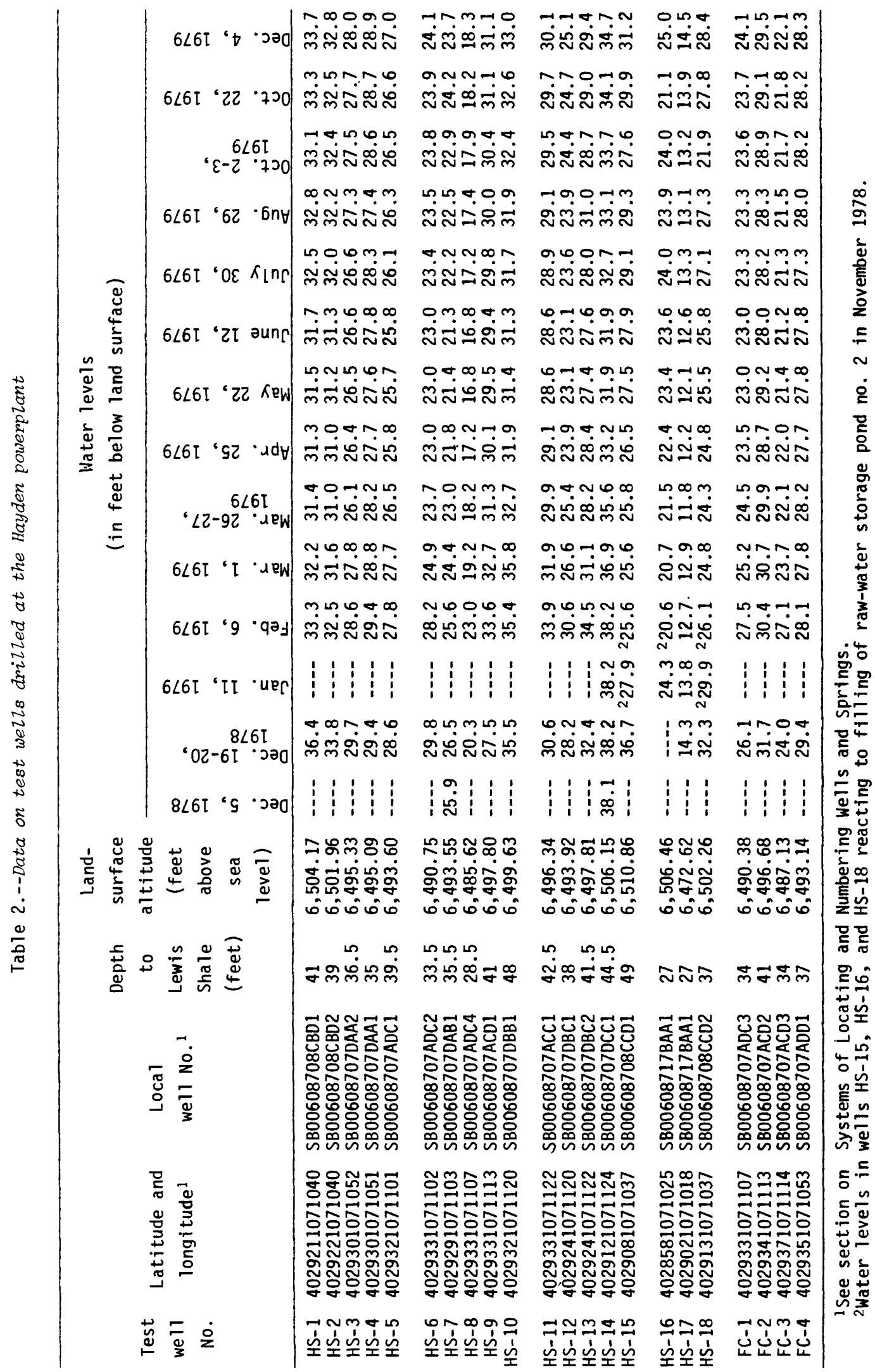



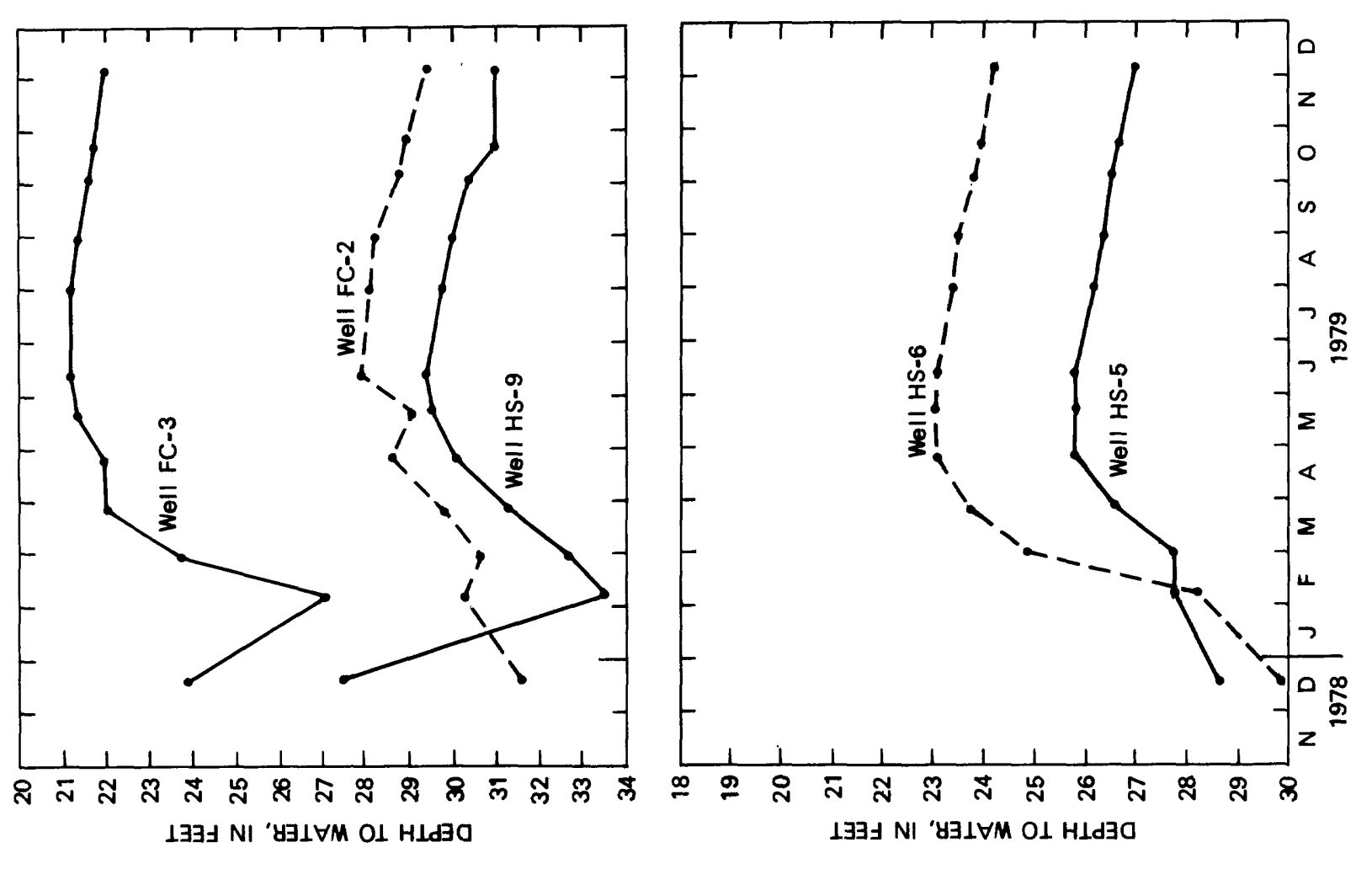

نُ

$1 \exists \exists y$ NI ' $8 \exists \perp \forall M$ OI HId $\exists O$
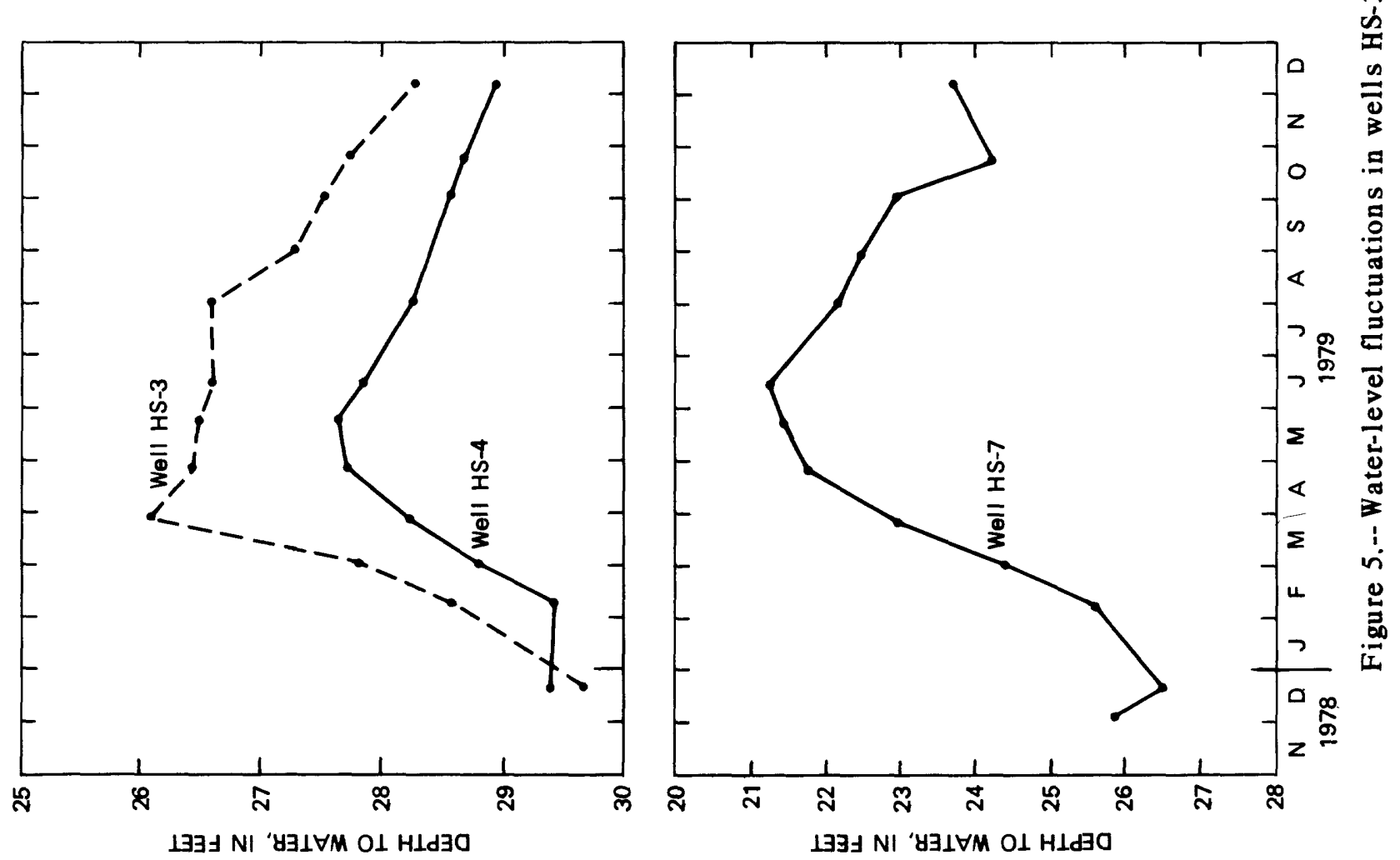

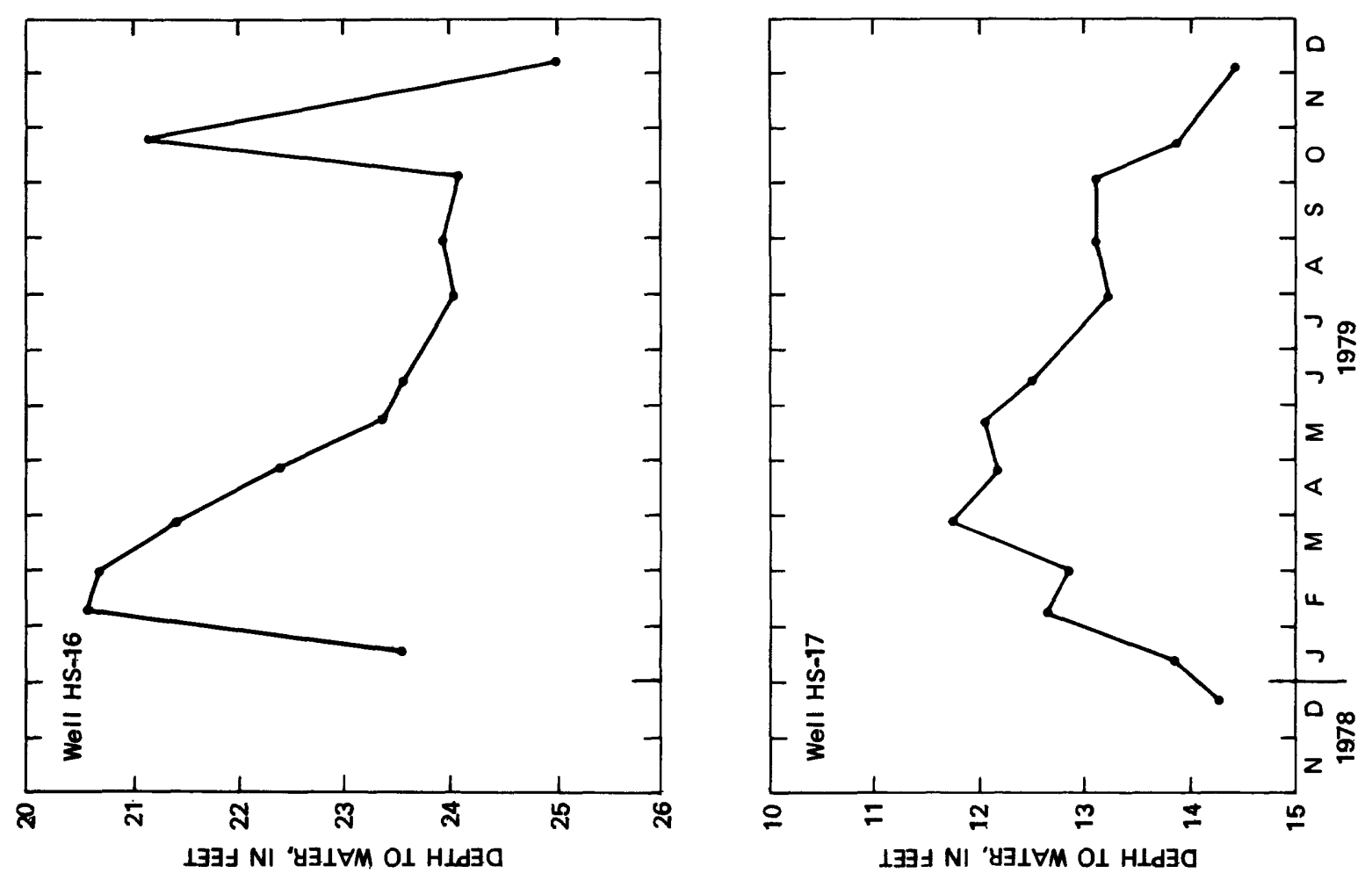

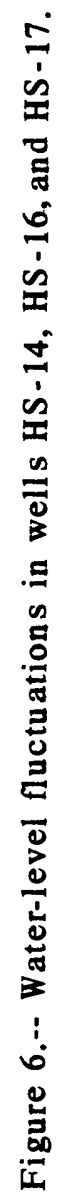

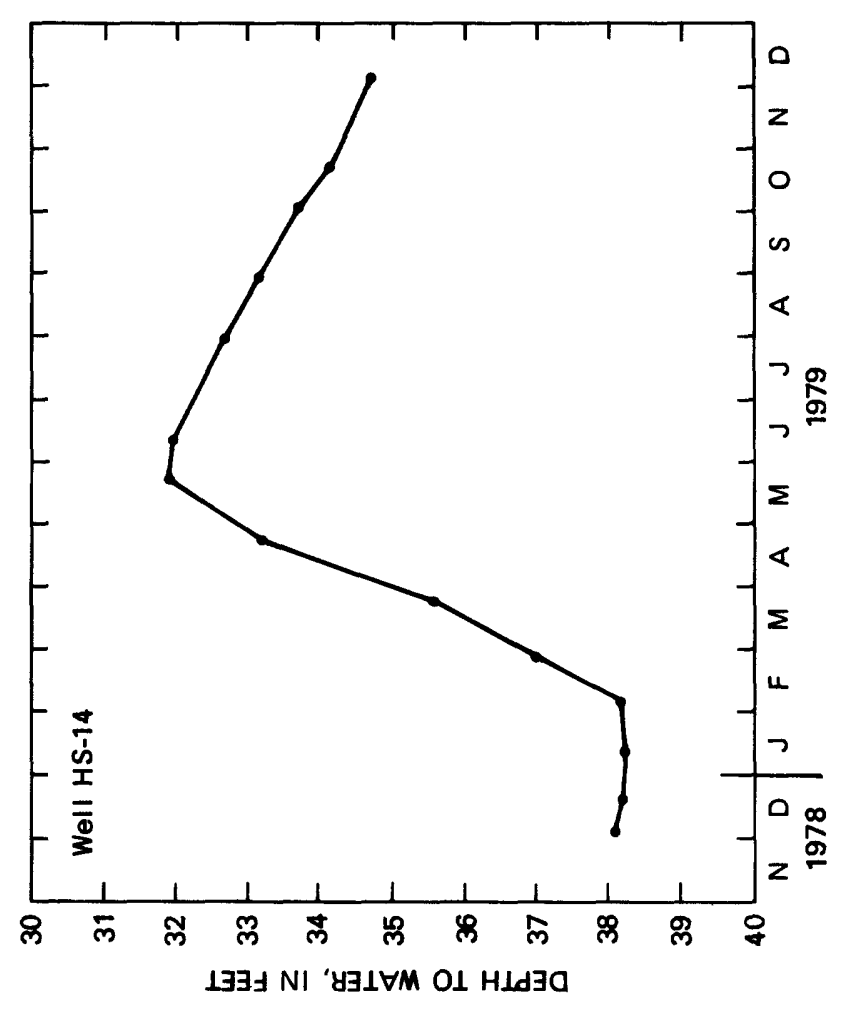




\section{Discharge Weir}

The discharge weir is a concrete box containing a $90^{\circ} \mathrm{V}$-notch weir used to measure the flow from the 30-in. RCP drain. The flow from the system, the largest single source of ground-water discharge in the area, is exceeded only by the combined flow from the springs along the lower (north) edge of the terrace. The average of four quarterly flow measurements made using the $V$-notch weir was about $0.40 \mathrm{ft}^{3} / \mathrm{s}$, varying seasonally from $0.26 \mathrm{ft}^{3} / \mathrm{s}$ in January to $0.82 \mathrm{ft} / \mathrm{s}$ in March. Water-quality samples were collected from January through 0ctober 1979 on a quarterly basis. The same general analysis schedule was used for samples taken from the discharge weir as was used for the wells and seeps. Results of the waterquality analyses and flow rates are presented in the Water-Quality Data section in this report.

\section{Streams}

Streams monitored in the Hayden powerplant study include the Yampa River near Hayden (U.S. Geological Survey streamflow-gaging station 09244410), Sage Creek above the Hayden powerplant, Sage Creek at U.S. Highway 40, and the Yampa River at Hayden, where one low-flow sample was collected. Sage Creek above the Hayden powerplant is an ephemeral stream, and the other streams are perennial. Flow rates for the Yampa River near Hayden were obtained from stage-discharge relations. Flow rates for Sage Creek above the Hayden powerplant were estimated using visual methods. Flow rates for Sage Creek at U.S. Highway 40 were estimated using the estimated flow of Sage Creek above the Hayden powerplant and estimates of inflows between the two sites. This method of estimating the flow for Sage Creek at U.S. Highway 40 was necessary because the site was located in backwater from the Yampa River. The same general scheme of water-quality sampling used for the wells and seeps was used for these surface-water sites. The results of the water-quality analyses and flow rates are presented in the Water-Quality Data section.

\section{AMBIENT GROUND WATER}

Data on the movement of the ambient ground water near the Hayden powerplant were sparse and insufficient. Most of the wells in the area are domestic and usually have no means of access for measuring the water level. Water levels are available only from drillers' logs and these levels are outdated. Surface topography is the main indicator of water movement and indicates that the ground water moves in a north-to-northwest direction, except near Sage Creek where it may flow northeast. Drillers' logs indicate that the maximum capacity of most wells is less than $20 \mathrm{gal} / \mathrm{min}$, and that the majority of the wells yield $10 \mathrm{gal} / \mathrm{min}$ or less.

Data on the quality of ground water near the plant were insufficient to define the ambient ground-water quality. Analyses of water sampled from well HS-14 indicated concentrations of nitrite plus nitrate larger than $10 \mathrm{mg} / \mathrm{L}$ (milligrams per liter). Well HS-14 is downgradient from a wheat field and may receive recharge from the field. Although well HS-14 is downgradient from the coal pile and the raw-water storage ponds, analyses of water from the well indicate that the quality of water is not influenced by water from either the coal pile or the raw-water 
storage ponds. Although the results of the analyses of other constituents probably are representative of the local ground water, a second control well--the Barnes well--was sampled in June and October for verification. The Barnes well (pl. 1) is a domestic well about $2 \mathrm{mi}$ southwest of the Hayden powerplant. According to the drillers' log, this well penetrates the Lewis Shale, but it is screened in and receives all of its water from the alluvium.

Data from well HS-14 and the Barnes well were averaged in an effort to define the ambient ground-water quality. The averages were: Boron, $220 \mu \mathrm{g} / \mathrm{L}$ (micrograms per liter); iron, $55 \mu \mathrm{g} / \mathrm{L}$; manganese, $35 \mu \mathrm{g} / \mathrm{L}$; selenium, $8 \mu \mathrm{g} / \mathrm{L}$; zinc, $40 \mu \mathrm{g} / \mathrm{L}$; and specific conductance, $1,050 \mu \mathrm{mhos} / \mathrm{cm}$ (micromhos per centimeter). These concentrations do not exceed the Colorado Department of Health (1977b) standards for agricultural use of water, except for a sample from well HS-14 that contained $15 \mu \mathrm{g} / \mathrm{L}$ of selenium. None of the concentrations exceeded the standards for drinking-water supply except for nitrite plus nitrate (which averaged $19 \mathrm{mg} / \mathrm{L}$ ) and one sample containing high selenium $(15 \mu \mathrm{g} / \mathrm{L})$. Data from well $\mathrm{HS}-14$ and the Barnes well are presented separately in the Water-Quality Data section.

Data on ambient ground-water quality were obtained from two additional sources and compared with the data from wells HS-14 and the Barnes well. The first source of data was a ground-water-quality study (R. S. Williams, U.S. Geological Survey, oral and written communs., 1981) in which 21 wells were sampled in the Grassy Creek valley, located about $1 \mathrm{mi}$ east of the Hayden powerplant (fig. 1). The aquifer system in Grassy Creek valley is about the same as that near the Hayden powerplant; the aquifer consists of alluvial terrace deposits underlain by a relatively impermeable shale. Williams sampled 21 wells and collected 78 samples of water for analysis of boron, manganese, selenium, and specific conductance. The average values for the 21 wells were: Boron, $140 \mu \mathrm{g} / \mathrm{L}$; manganese, $165 \mu \mathrm{g} / \mathrm{L}$; selenium, less than $1 \mu \mathrm{g} / \mathrm{L}$; and specific conductance, $1,470 \mu \mathrm{mhos} / \mathrm{cm}$. The highest values were: Boron, $440 \mu \mathrm{g} / \mathrm{L}$; manganese, 2,000 $\mathrm{gg} / \mathrm{L}$; selenium, $1 \mu \mathrm{g} / \mathrm{L}$; and specific conductance, $3,400 \mu \mathrm{mhos} / \mathrm{cm}$.

The second source of data on the quality of the ambient ground water was the computer data files of the U.S. Environmental Protection Agency and the U.S. Geological Survey. The area considered for retrieval of the data from the computer files was from south of U.S. Highway 40 to the southern boundary of the area shown in figure 1 and from longitude $107^{\circ} 05^{\prime} 00^{\prime \prime}$ to longitude $107^{\circ} 15^{\prime} 00^{\prime \prime}$. The computer data files had data on six wells not included in the Williams ground-water-quality or the Hayden powerplant studies. There was a variable number of analyses for each constituent. Boron was determined in three analyses; manganese, in six analyses; selenium, in six analyses; and specific conductance, in six analyses. The average values were: Boron, $141 \mu \mathrm{g} / \mathrm{L}$; manganese, $28 \mu \mathrm{g} / \mathrm{L}$; selenium, $5 \mu \mathrm{g} / \mathrm{L}$; and specific conductance, $1,500 \mu \mathrm{mhos} / \mathrm{cm}$. The highest values were: Boron, $284 \mu \mathrm{g} / \mathrm{L}$; manganese, $1,450 \mu \mathrm{g} / \mathrm{L}$; selenium, $7 \mu \mathrm{g} / \mathrm{L}$; and specific conductance, $2,950 \mu \mathrm{mhos} / \mathrm{cm}$.

An analysis of the data from the Williams ground-water-quality study and the computer data files indicates the data from well HS-14 and the Barnes well are an acceptable indicator of ambient ground-water quality in the area. None of the wells had analyses in which the boron exceeded the Colorado Department of Health (1977b) proposed water-quality standard of $750 \mu \mathrm{g} / \mathrm{L}$. 


\section{HAYDEN POWERPLANT EFFLUENT}

Although a sample of the low-quality wastes was not obtained, one sample of Hayden powerplant brine effluent disposed of in the evaporation pond was supplied by powerplant personnel. The brine effluent sample, taken from the wastewater concentrator ( $f \mathrm{ig} .2$ ), was highly colored and contained flocculate after filtration through a 0.45 -micron filter. An analysis indicated the following: Specific conductance, 75,000 umhos/cm; carbonate, $240 \mathrm{mg} / \mathrm{L}$; boron, $110,000 \mu \mathrm{g} / \mathrm{L}$; iron, $1,700 \mu \mathrm{g} / \mathrm{L}$; manganese, 37,000 $\mathrm{gg} / \mathrm{L}$; nickel, $300 \mu \mathrm{g} / \mathrm{L}$; selenium, $220 \mu \mathrm{g} / \mathrm{L}$; and $\mathrm{pH}$, 6.2. The analytical dilution factor for selenium was 25; therefore, the value for selenium may be in error, even though several aliquots were analyzed and the average value reported.

Because we were able to obtain only one sample from the wastewater concentrator and no samples from the low-quality wastes, it is not known if this sample truly represents the inflow into the evaporation pond. However, it is the only available indicator of effluent quality.

\section{EFFECTS OF BORON}

Boron is of concern because it is a byproduct of coal burning and may be introduced into the local ground water by effluents from the Hayden powerplant. Whereas boron is important as a plant nutrient but is toxic to plants in high concentrations, a discussion of the occurrence, movement, effects, and recommended maximum levels is relevant. This discussion will be useful in assessing the effects of boron when the water is used for agriculture.

Boron usually is reported in terms of the element boron, and no effort is made to differentiate the species present. At the $\mathrm{pH}$ of natural water--less than $\mathrm{pH}$ 8.7--the predominant species would be $\mathrm{H}_{3} \mathrm{BO}_{3}$ (aqueous) and to a lesser degree, $\mathrm{H}_{2} \mathrm{BO}_{3}$. At $\mathrm{pH} 8.2$ the ratio of $\mathrm{H}_{3} \mathrm{BO}_{3}$ (aqueous) to $\mathrm{H}_{2} \mathrm{BO}_{3}$ would be 10:1 (Hem, 1970). Boron has been identified in several complex mineral forms; colemanite and kernite are two which are found in evaporate deposits in California and Nevada. Boron also is found in simple forms--calcium, magnesium, and sodium borates. Organic forms of boron also have been identified; they are the result of micro-organisms and plants utilizing boron in their growth. The organic forms of boron usually are oxidized to the inorganic form when the micro-organisms and plants die (U.S. Department of Agriculture, 1957). Boron in natural water does not seem to conform to a simple solubility constant but is probably controlled by several factors that are not well understood (Hem, 1970).

Movement of boron in the soil column is a complex procedure, involving pH, soil type, and organic matter (U.S. Department of Agriculture, 1957). Boron is readily adsorbed onto clays and to a lesser degree onto silts. Little or no adsorption occurs on sand. The type of cation has little or no effect on the rate or amount of adsorption. An increase in pH will increase adsorption and a decrease will lower adsorption. The effects of $\mathrm{pH}$ are reversible; that is, an increase in $\mathrm{pH}$ will increase the amount of boron fixed in the soil, and if acid is used to lower the $\mathrm{pH}$, the amount of boron fixed in the soil will decrease. This reaction 
is rapid and appears to be continuous. Organic matter appears to decrease the amount of boron fixed in the soil and release more boron into the water column to be available for uptake for life forms (U.S. Department of Agriculture, 1957).

Crops such as sugar beets, alfalfa, and clover are affected by a deficiency of boron in the soil. Boron is a necessary nutrient in the growth of legumes, especially alfalfa. Fertilizers that contain boron have been applied to crops for many years. The main results of boron deficiency are reduced growth, cellular change, and finally death. It is difficult to determine the amount of boron needed for growth by various plants because only a small fraction of the boron in the soil is in a form available for plant growth. Boron, as measured in the available form, is needed in concentrations of $0.5 \mathrm{mg} / \mathrm{g}$ (milligrams per gram) for satisfactory growth of alfalfa, sugar beets, red clover, and sweet clover (U.S. Department of Agriculture, 1957).

Boron, although a vital nutrient in plant growth, is a toxic substance when excess quantities are present. The problem of boron toxicity first became prominent during World War 1 , when potash salts, usually purchased from Germany, were mined from Searles Lake in California. Application of this potash resulted in damage to potatoes and vegetables. Analyses of the potash indicated that it contained more than 11-percent boron. The potash was then refined, the boron removed, and the problem was solved. Symptoms of boron poisoning are yellowish-brown spots on leaves (U.S. Department of Agriculture, 1957).

The problem of boron poisoning is not confined only to the application of fertilizer, but also to the application of irrigation water. Several plants, notably beans and fruit trees, are sensitive to boron. Crops such as alfalfa, sugar beets, clovers, and carrots are among the most tolerant crops. The relative tolerance of plants to boron in irrigation water is listed in table 3 . The permissible limits of concentration of boron in several classes of water used for irrigation are shown in table 4. Irrigation water containing more than the recommended concentration of boron may not produce immediate harmful effects. Water containing as much as $2 \mathrm{mg} / \mathrm{L}$ of boron may be used on neutral and alkaline soils for some time without injury to sensitive plants. However, if the soils are acid, damage may occur rapidly [National Academy of Sciences and National Academy of Engineering, $1973(1974)]$.

In Colorado, the maximum permissible limit of $750 \mu \mathrm{g} / \mathrm{L}$ for boron has been established by the Colorado Department of Health (1977b) only for waters for agricultural use. Limits have not been established for water supply, aquatic life, or other uses.

Gastrointestinal and pulmonary disorders have been observed in lambs when the concentration of boron is unusually high in both the soil and water supplies. If large amounts of boron are ingested by humans, some serious toxic effects may be produced (Gough and others, 1979). More information is needed on the possible effects of boron before standards may be established for the permissible concentration of boron in water used for drinking and public supply. 
Table 3.--Relative tolerance of plants to boron

[In each group, the plants first named are the most tolerant and the last named are the least tolerant. From U.S. Department of Agriculture (1954)]

\begin{tabular}{lll}
\hline \multicolumn{1}{c}{ Tolerant } & \multicolumn{1}{c}{ Semitolerant } & \multicolumn{1}{c}{ Sensitive } \\
\hline Athel (Tamarix aphylla) & Sunflower (native) & Pecan \\
Asparagus & Potato & Black walnut \\
Palm (Phoenix canariensis) & Acala cotton & Persian (English) walnut \\
Date palm (P. dactylifera) & Pima cotton & Jerusalem-artichoke \\
Sugar beet & Tomato & Navy bean \\
Mangoes & Sweetpea & American elm \\
Garden beet & Radish & Plum \\
Alfalfa & Field pea & Pear \\
Gladiolus & Raggedrobin rose & Apple \\
Broadbean & Olive & Grape (Sultanina and Malaga) \\
& Barley & Kadota fig \\
Onion & Wheat & Persimmon \\
Turnip & Corn & Cherry \\
Cabbage & Milo & Peach \\
Lettuce & Oat & Apricot \\
Carrot & Zinnia & Thornless blackberry \\
& Pumpkin & Orange \\
& Bell pepper & Avocado \\
& Sweet potato & Grapefruit \\
& Lima bean & Lemon \\
\hline
\end{tabular}

Table 4.--Permissible limits for concentrations of boron in several classes of irrigation water

[Concentration of boron in mg/L. From U.S. Department of Agriculture (1954)]

\begin{tabular}{lccc}
\hline \multirow{2}{*}{$\begin{array}{c}\text { Class } \\
\text { of } \\
\text { water }\end{array}$} & \multicolumn{3}{c}{ For crops that are } \\
\cline { 2 - 4 } & Sensitive & Semitolerant & Tolerant \\
\hline Excellent- & Less than 0.33 & Less than 0.67 & Less than 1.0 \\
Good- & $0.33-0.67$ & $0.67-1.33$ & $1.0-2.0$ \\
Permissible- & $0.67-1.0$ & $1.33-2.0$ & $2.0-3.0$ \\
Doubtful- & $1.0-1.25$ & $2.0-2.5$ & $3.0-3.75$ \\
Unsuitable-- & More than 1.25 & More than 2.50 & More than 3.75 \\
\hline
\end{tabular}




\section{EFFECTS OF EFFLUENTS}

The effects of effluents from the Hayden powerplant on the local ground water are presented for five categories: Ponds, wells, seeps, the discharge weir, and streams. Data on the concentrations of trace elements in analyzed samples of water from the ponds, seeps, the discharge weir, and streams, and the number of samples which exceeded the Colorado Department of Health (1977b) standards for agricultural use of water are given in tables 5 and 6 . Trace-element data are given in tables 7 and 8.

\section{Ponds}

The ponds at the Hayden powerplant can be classified as either effluent (evaporation, intermediate-quality, oil-skimmer, and high-quality) or raw-water storage (raw-water storage ponds no. 1 and no. 2). Because the coal-pile runoff pond was dry during most of the study period due to evaporation, it was not considered to have a major effect on the ground water. The relationship of specific conductance and boron with time for water in selected ponds is shown in figure 7 .

The evaporation pond had the highest average specific conductance $(6,590$ $\mu \mathrm{mhos} / \mathrm{cm})$ and the highest average boron concentration $(4,800 \mu \mathrm{g} / \mathrm{L})$ of the five ponds sampled. Concentrations of these constituents varied greatly during the study. The october 1979 sample contained the largest values of specific conductance $(13,800 \mu \mathrm{mhos} / \mathrm{cm})$ and boron $(13,000 \mu \mathrm{g} / \mathrm{L})$. The December 1978 sample contained the smallest value of specific conductance $(1,850 \mu \mathrm{mhos} / \mathrm{cm})$ and the June 1979 sample contained the smallest concentration of boron $(530 \mu \mathrm{g} / \mathrm{L})$.

A large discrepancy was found between the concentrations of selenium in the effluent entering the evaporation pond and in the water in the pond. The effluent contained $220 \mathrm{\mu g} / \mathrm{L}$ of dissolved selenium (see page 21 for discussion of effluent sample), whereas the pond samples had a maximum concentration of $14 \mu \mathrm{g} / \mathrm{L}$ and averaged $6 \mu \mathrm{g} / \mathrm{L}$. The concentration of selenium in the pond decreased during the study. A sample of the bottom material from the evaporation pond analyzed for the following trace elements was found to contain: Boron, $560 \mu \mathrm{g} / \mathrm{g}$; copper, $35 \mu \mathrm{g} / \mathrm{g}$; manganese, $11 \mu \mathrm{g} / \mathrm{g}$; selenium, none detected; and silver, $4 \mu \mathrm{g} / \mathrm{g}$. The material was primarily fly ash, and material from the clay liner of the pond was not included. The analyses of the evaporation-pond water and the evaporation-pond bottom material (fly ash) did not indicate the presence of large amounts of selenium. The concentration of selenium in the downgradient wells was generally lower than in either the evaporation pond or the ambient ground water. Further study is needed to determine the fate of the selenium.

Seasonal evaporation, precipitation, and snowmelt will cause fluctuations in the quality of water in the evaporation pond. The water will probably reach its lowest annual concentration of constituents in early summer when runoff is greatest and reach its highest concentration in late summer. It is not possible to estimate the ultimate concentration of constituents in the evaporation pond, but the long-term trend is probably toward increasing concentration. 
Table 5.--Average concentrations of selected trace elements in water from ponds, seeps, streams, and the discharge weir and the percentages as compared to the concentrations of the same elements in the ambient ground water

[NS=not significant; NA=not applicable; concentrations in microgram per liter, $\mu \mathrm{g} / \mathrm{L}]$

\begin{tabular}{|c|c|c|c|c|c|c|c|c|}
\hline \multirow{3}{*}{ Site } & \multicolumn{8}{|c|}{ Trace elements } \\
\hline & \multicolumn{2}{|c|}{ Boron } & \multicolumn{2}{|c|}{ Selenium } & \multicolumn{2}{|c|}{ Manganese } & \multicolumn{2}{|c|}{ Iron } \\
\hline & $\mu g / L$ & Percent & $\mu g / L$ & Percent & $\mu g / L$ & Percent & $\mu \mathrm{g} / \mathrm{L}$ & Percent \\
\hline $\begin{array}{l}\text { Ambient ground water-- } \\
\text { Evaporation pond- } \\
\text { Intermediate-quality }\end{array}$ & $\begin{array}{r}220 \\
4,800\end{array}$ & $\begin{array}{r}100 \\
2,200\end{array}$ & $\begin{array}{l}8 \\
5\end{array}$ & $\begin{array}{r}100 \\
\text { NS }\end{array}$ & $\begin{array}{r}35 \\
420\end{array}$ & $\begin{array}{r}100 \\
1,200\end{array}$ & $\begin{array}{l}55 \\
33\end{array}$ & $\begin{array}{r}100 \\
60\end{array}$ \\
\hline $\begin{array}{l}\text { pil-skimmer pond- } \\
\text { High-quality pond- } \\
\text { Raw-water storage }\end{array}$ & $\begin{array}{l}1,800 \\
1,800 \\
1,300\end{array}$ & $\begin{array}{l}820 \\
820 \\
590\end{array}$ & $\begin{array}{l}3 \\
6 \\
3\end{array}$ & $\begin{array}{l}\text { NS } \\
\text { NS } \\
\text { NS }\end{array}$ & $\begin{array}{r}63 \\
120 \\
73\end{array}$ & $\begin{array}{l}180 \\
340 \\
210\end{array}$ & $\begin{array}{l}37 \\
30 \\
40\end{array}$ & $\begin{array}{l}67 \\
55 \\
73\end{array}$ \\
\hline pond no. 1 & 85 & 39 & 0 & NA & 30 & 86 & 230 & 420 \\
\hline $\begin{array}{l}\text { Sage Creek at } \\
\text { U.S. Highway 40-1- } \\
\text { Sage Creek above }\end{array}$ & 320 & NA & 57 & NA & 130 & NA & 100 & NA \\
\hline $\begin{array}{l}\text { Hayden powerplant--- } \\
\text { Discharge weir- }\end{array}$ & $\begin{array}{r}250 \\
1,600\end{array}$ & $\begin{array}{r}N A \\
730\end{array}$ & $\begin{array}{l}61 \\
13\end{array}$ & $\begin{array}{l}\text { NA } \\
\text { NA }\end{array}$ & $\begin{array}{l}740 \\
130\end{array}$ & $\begin{array}{r}N A \\
370\end{array}$ & 120 & NA \\
\hline $\begin{array}{l}\text { Gravel pit seep } \\
\text { Seep HS-1 } \\
\text { Seep HS-2 } \\
\text { Seep HS } 3- \\
\text { Seep HS-4 }\end{array}$ & $\begin{array}{l}1,200 \\
1,300 \\
1,400 \\
1,900 \\
1,800\end{array}$ & $\begin{array}{l}550 \\
590 \\
640 \\
860 \\
820\end{array}$ & $\begin{array}{l}2 \\
4 \\
6 \\
3 \\
6\end{array}$ & $\begin{array}{l}\text { NS } \\
\text { NS } \\
\text { NS } \\
\text { NS } \\
\text { NS }\end{array}$ & $\begin{array}{r}810 \\
12 \\
33 \\
33 \\
47\end{array}$ & $\begin{array}{r}2,300 \\
34 \\
94 \\
94 \\
130\end{array}$ & $\begin{array}{r}260 \\
70 \\
180 \\
130 \\
90\end{array}$ & $\begin{array}{l}470 \\
130 \\
330 \\
240 \\
160\end{array}$ \\
\hline $\begin{array}{l}\text { Seep HS-5- } \\
\text { Seep HS-6- } \\
\text { Seep HS-7 } \\
\text { Seep HS-8- }\end{array}$ & $\begin{array}{l}1,000 \\
1,600 \\
1,300 \\
1,300\end{array}$ & $\begin{array}{l}450 \\
730 \\
590 \\
590\end{array}$ & $\begin{array}{l}6 \\
2 \\
2 \\
4\end{array}$ & $\begin{array}{l}\text { NS } \\
\text { NS } \\
\text { NS } \\
\text { NS }\end{array}$ & $\begin{array}{l}5 \\
40 \\
15 \\
35\end{array}$ & $\begin{array}{r}14 \\
110 \\
43 \\
100\end{array}$ & $\begin{array}{l}5 \\
40 \\
40 \\
40\end{array}$ & $\begin{array}{r}9 \\
73 \\
73 \\
73\end{array}$ \\
\hline $\begin{array}{l}\text { Yampa River } \\
\text { near Hayden } \\
\text { Yampa River } \\
\text { at Hayden- }\end{array}$ & 72 & NA & 0 & NA & 40 & $\begin{array}{r}\text { NA } \\
-----\end{array}$ & 123 & NA \\
\hline
\end{tabular}


Table 6.-Number of samples of water from ponds, seeps, streams, and the discharge weir analyzed for boron and manganese compared with the number of scomples exceeding the Colorado Department of Health (1977b) standards for agricultural use of water

\begin{tabular}{|c|c|c|c|c|}
\hline \multirow[t]{2}{*}{ Site } & \multicolumn{2}{|c|}{ Number of samples } & \multicolumn{2}{|c|}{$\begin{array}{c}\text { Number of samples that exceeded } \\
\text { Colorado water-quality standards } \\
\text { for agricultural use }\end{array}$} \\
\hline & Doron & Manganese & Boron & Manganese \\
\hline $\begin{array}{l}\text { Evaporation pond- } \\
\text { Intermediate-quality pond-- } \\
\text { Oil-skimmer pond- } \\
\text { High-quality pond- } \\
\text { Raw-water storage pond } \\
\text { no. } 1 \text { - }\end{array}$ & $\begin{array}{l}4 \\
4 \\
4 \\
4\end{array}$ & $\begin{array}{l}3 \\
3 \\
3 \\
3\end{array}$ & $\begin{array}{l}3 \\
4 \\
4 \\
4\end{array}$ & $\begin{array}{l}2 \\
0 \\
0 \\
0\end{array}$ \\
\hline $\begin{array}{l}\text { Seep HS-1 } \\
\text { Seep HS-2 } \\
\text { Seep HS-3 } \\
\text { Seep HS-4 } \\
\text { Seep HS-5 }\end{array}$ & $\begin{array}{l}4 \\
4 \\
4 \\
4 \\
3\end{array}$ & $\begin{array}{l}3 \\
3 \\
3 \\
3 \\
2\end{array}$ & $\begin{array}{l}0 \\
4 \\
3 \\
3 \\
3\end{array}$ & $\begin{array}{l}0 \\
0 \\
0 \\
0 \\
0\end{array}$ \\
\hline $\begin{array}{l}\text { Seep HS-6 } \\
\text { Seep HS-7 } \\
\text { Seep HS-8 } \\
\text { Gravel-pit seep } \\
\text { Discharge weir }\end{array}$ & $\begin{array}{l}3 \\
3 \\
2 \\
4 \\
4\end{array}$ & $\begin{array}{l}2 \\
2 \\
2 \\
3 \\
3\end{array}$ & $\begin{array}{l}3 \\
2 \\
1 \\
4 \\
4\end{array}$ & $\begin{array}{l}0 \\
0 \\
0 \\
2 \\
1\end{array}$ \\
\hline $\begin{array}{l}\text { Sage Creek above Hayden---- } \\
\text { Sage Creek at } \\
\text { U.S. Highway 40 }\end{array}$ & 2 & 2 & 0 & 1 \\
\hline
\end{tabular}


Table 7.--Average concentrations of selected trace elements in water from wells and the percentages as compared to the concentrations of the same elements in the combient ground water

[NS=not significant; concentrations in microgram per liter, $\mu \mathrm{g} / \mathrm{L}$ ]

\begin{tabular}{|c|c|c|c|c|c|c|c|c|}
\hline \multirow{3}{*}{ Site } & \multicolumn{8}{|c|}{ Trace elements } \\
\hline & \multicolumn{2}{|c|}{ Boron } & \multicolumn{2}{|c|}{ Selenium } & \multicolumn{2}{|c|}{ Manganese } & \multicolumn{2}{|c|}{ Iron } \\
\hline & $\mu \mathrm{g} / \mathrm{L}$ & Percent & $\mu g / L$ & Percent & $\mu \mathrm{g} / \mathrm{L}$ & Percent & $\mu g / L$ & Percent \\
\hline $\begin{array}{l}\text { Ambient ground water-- } \\
\text { Well HS-1 } \\
\text { Well HS-2 } \\
\text { Well HS-3 } \\
\text { Well HS-4 }\end{array}$ & $\begin{array}{r}220 \\
960 \\
1,000 \\
1,200 \\
1,200\end{array}$ & $\begin{array}{l}100 \\
440 \\
450 \\
550 \\
550\end{array}$ & $\begin{array}{l}8 \\
4 \\
4 \\
1 \\
1\end{array}$ & $\begin{array}{r}100 \\
\text { NS } \\
\text { NS } \\
\text { NS } \\
\text { NS }\end{array}$ & $\begin{array}{r}35 \\
250 \\
500 \\
93 \\
360\end{array}$ & $\begin{array}{r}100 \\
710 \\
1,400 \\
270 \\
1,000\end{array}$ & $\begin{array}{l}55 \\
10 \\
13 \\
50 \\
40\end{array}$ & $\begin{array}{r}100 \\
18 \\
24 \\
91 \\
73\end{array}$ \\
\hline $\begin{array}{l}\text { Well HS-5 } \\
\text { Well HS-6 } \\
\text { Well HS-7 } \\
\text { Well HS-8 } \\
\text { Well HS-9 }\end{array}$ & $\begin{array}{l}1,500 \\
1,200 \\
1,100 \\
1,600 \\
1,700\end{array}$ & $\begin{array}{l}680 \\
550 \\
500 \\
730 \\
770\end{array}$ & $\begin{array}{l}2 \\
3 \\
4 \\
4 \\
5\end{array}$ & $\begin{array}{l}\text { NS } \\
\text { NS } \\
\text { NS } \\
\text { NS } \\
\text { NS }\end{array}$ & $\begin{array}{r}120 \\
370 \\
100 \\
290 \\
73\end{array}$ & $\begin{array}{r}340 \\
1,100 \\
290 \\
830 \\
210\end{array}$ & $\begin{array}{l}27 \\
27 \\
40 \\
10 \\
15\end{array}$ & $\begin{array}{l}49 \\
49 \\
73 \\
18 \\
27\end{array}$ \\
\hline $\begin{array}{l}\text { Well HS-10 } \\
\text { Well HS-11 } \\
\text { Well HS-12 } \\
\text { Well HS-13 } \\
\text { Well HS-15 }\end{array}$ & $\begin{array}{r}1,300 \\
1,000 \\
1,800 \\
1,600 \\
670\end{array}$ & $\begin{array}{l}590 \\
450 \\
820 \\
730 \\
300\end{array}$ & $\begin{array}{r}6 \\
5 \\
10 \\
10 \\
3\end{array}$ & $\begin{array}{l}\text { NS } \\
\text { NS } \\
\text { NS } \\
\text { NS } \\
\text { NS }\end{array}$ & $\begin{array}{l}37 \\
20 \\
67 \\
70 \\
40\end{array}$ & $\begin{array}{r}110 \\
57 \\
190 \\
200 \\
110\end{array}$ & $\begin{array}{r}13 \\
30 \\
23 \\
53 \\
150\end{array}$ & $\begin{array}{r}24 \\
55 \\
42 \\
96 \\
270\end{array}$ \\
\hline $\begin{array}{l}\text { Well HS-16 } \\
\text { Well HS-17 } \\
\text { Well HS-18 }\end{array}$ & $\begin{array}{r}2,700 \\
510 \\
960\end{array}$ & $\begin{array}{r}1,200 \\
230 \\
440\end{array}$ & $\begin{array}{r}12 \\
3 \\
4\end{array}$ & $\begin{array}{l}\text { NS } \\
\text { NS } \\
\text { NS }\end{array}$ & $\begin{array}{r}300 \\
1,400 \\
210\end{array}$ & $\begin{array}{r}860 \\
4,000 \\
600\end{array}$ & $\begin{array}{r}93 \\
600 \\
43\end{array}$ & $\begin{array}{r}170 \\
1,100 \\
78\end{array}$ \\
\hline $\begin{array}{l}\text { Well } F C-1 \\
\text { Well FC-2 } \\
\text { Well FC- } 3 \\
\text { Well FC-4 }\end{array}$ & $\begin{array}{l}1,700 \\
1,700 \\
1,800 \\
1,200\end{array}$ & $\begin{array}{l}770 \\
770 \\
820 \\
550\end{array}$ & $\begin{array}{l}3 \\
6 \\
6 \\
2\end{array}$ & $\begin{array}{l}\text { NS } \\
\text { NS } \\
\text { NS } \\
\text { NS }\end{array}$ & $\begin{array}{r}110 \\
50 \\
110 \\
30\end{array}$ & $\begin{array}{r}310 \\
140 \\
310 \\
86\end{array}$ & $\begin{array}{r}130 \\
17 \\
20 \\
17\end{array}$ & $\begin{array}{r}240 \\
31 \\
36 \\
31\end{array}$ \\
\hline
\end{tabular}


Table 8.--Number of water samples analyzed for boron and manganese compared with the number of samples exceeding Colorado Department of Health (1977b) for agricultural use of water from wells

\begin{tabular}{|c|c|c|c|c|}
\hline \multirow[t]{2}{*}{ Site } & \multicolumn{2}{|c|}{ Number of samples } & \multicolumn{2}{|c|}{$\begin{array}{c}\text { Number of samples that exceeded } \\
\text { Colorado water-quality standards } \\
\text { for agricultural use }\end{array}$} \\
\hline & & & Boron & Manganese \\
\hline $\begin{array}{l}\text { Well HS-1 } \\
\text { Well HS-2 } \\
\text { Well HS-3 } \\
\text { Well HS-4 } \\
\text { Well HS-5 }\end{array}$ & $\begin{array}{l}4 \\
4 \\
4 \\
4 \\
4\end{array}$ & $\begin{array}{l}3 \\
3 \\
3 \\
3 \\
3\end{array}$ & $\begin{array}{l}4 \\
4 \\
4 \\
4 \\
3\end{array}$ & $\begin{array}{l}1 \\
1 \\
0 \\
2 \\
0\end{array}$ \\
\hline $\begin{array}{l}\text { Well HS-6 } \\
\text { Well HS-7 } \\
\text { Well HS } 8 \\
\text { Well HS-9 } \\
\text { Well HS-10 }\end{array}$ & $\begin{array}{l}4 \\
4 \\
4 \\
4 \\
4\end{array}$ & $\begin{array}{l}3 \\
3 \\
3 \\
3 \\
3\end{array}$ & $\begin{array}{l}2 \\
2 \\
3 \\
4 \\
4\end{array}$ & $\begin{array}{l}2 \\
1 \\
1 \\
0 \\
0\end{array}$ \\
\hline $\begin{array}{l}\text { Well HS-11 } \\
\text { Well HS-12 } \\
\text { Well HS-13 } \\
\text { Well HS-14 } \\
\text { Well HS-15 }\end{array}$ & $\begin{array}{l}4 \\
4 \\
4 \\
4 \\
4\end{array}$ & $\begin{array}{l}3 \\
3 \\
3 \\
3 \\
3\end{array}$ & $\begin{array}{l}3 \\
4 \\
4 \\
0 \\
1\end{array}$ & $\begin{array}{l}0 \\
0 \\
0 \\
0 \\
0\end{array}$ \\
\hline $\begin{array}{l}\text { Well HS-16 } \\
\text { Well HS-17 } \\
\text { Well HS-18 }\end{array}$ & $\begin{array}{l}4 \\
4 \\
4\end{array}$ & $\begin{array}{l}3 \\
3 \\
3\end{array}$ & $\begin{array}{l}3 \\
0 \\
3\end{array}$ & $\begin{array}{l}1 \\
2 \\
1\end{array}$ \\
\hline $\begin{array}{l}\text { Well } \mathrm{FC}-1 \\
\text { Well } \mathrm{FC}-2 \\
\text { Well } \mathrm{FC}-3 \\
\text { Well } \mathrm{FC}-4 \\
\text { Barnes Well }\end{array}$ & $\begin{array}{l}4 \\
4 \\
4 \\
4 \\
2\end{array}$ & $\begin{array}{l}3 \\
3 \\
3 \\
3 \\
1\end{array}$ & $\begin{array}{l}3 \\
4 \\
4 \\
2 \\
0\end{array}$ & $\begin{array}{l}0 \\
0 \\
1 \\
0 \\
0\end{array}$ \\
\hline
\end{tabular}




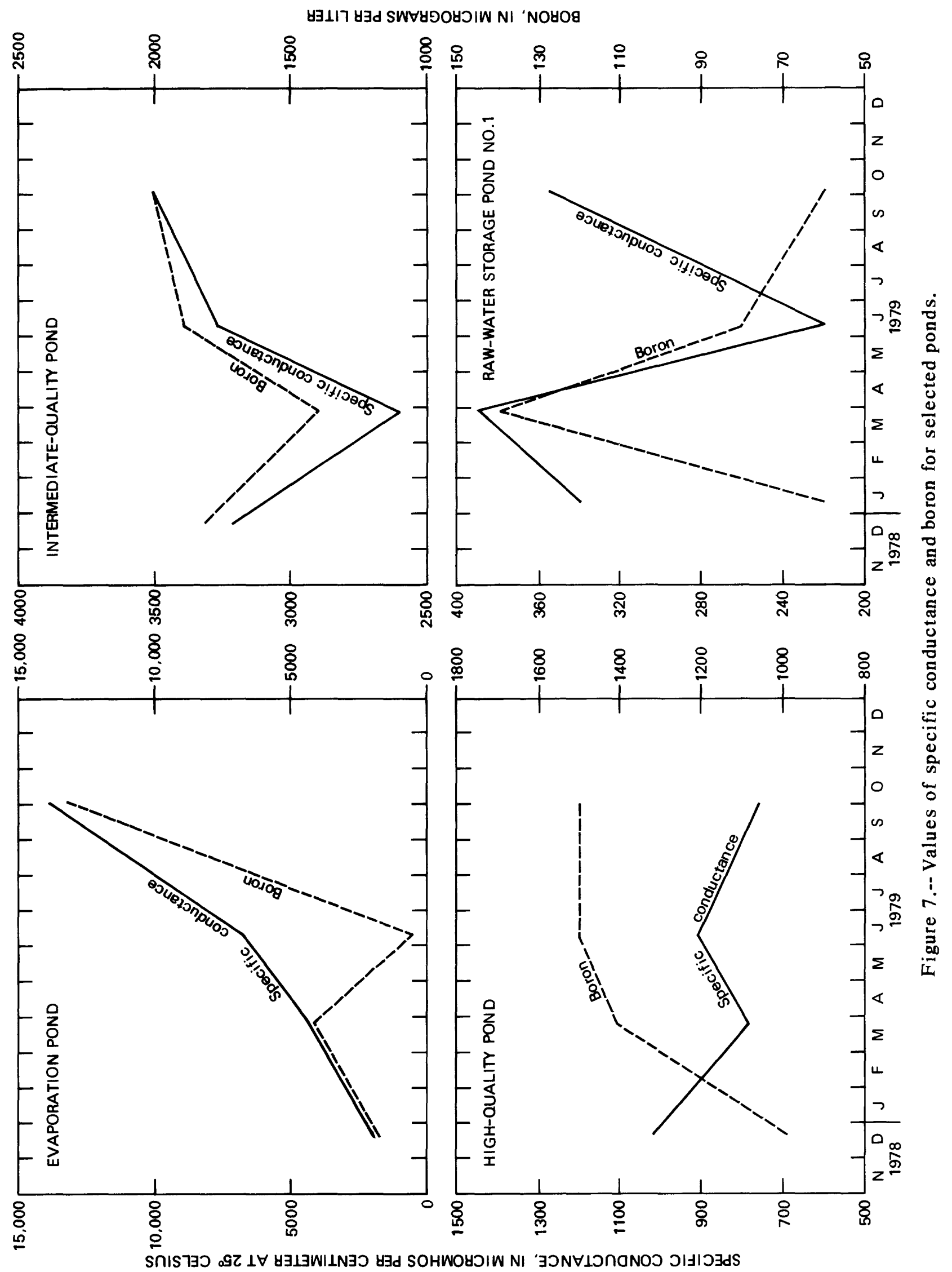


The intermediate-quality pond had the most consistent water quality of all the ponds sampled. The average specific conductance was $3,140 \mu \mathrm{mhos} / \mathrm{cm}$ and varied only by about $500 \mu$ mhos/cm during the study. The average boron concentration was $1,800 \mu \mathrm{g} / \mathrm{L}$. The quality of the pond was adequate for raising trout. of the trace elements sampled, only boron exceeded the recommended Colorado Department of Health (1977b) standard for agricultural use of water. Only two samples--one high in copper, the other high in zinc--exceeded the recommended Colorado Department of Health (1977b) standards for aquatic life.

The average specific conductance in the oil-skimmer pond (the smallest pond sampled) was $1,560 \mu \mathrm{mhos} / \mathrm{cm}$, and the average boron concentration was 1,800 $\mu \mathrm{g} / \mathrm{L}$. Boron was the only constituent that was in excess of the recommended Colorado Department of Health (1977b) standards for agricultural use of water. of particular interest was the October 1979 sample, which had a pH of 3.0; this value was verified by repeated measurements in the field and by analysis in the laboratory. The sample did not contain excessive amounts of any other analyzed constituent. The $\mathrm{pH}$ increased to about 6.0 the following day. It was subsequently determined that this increase was due to an incomplete construction modification resulting in demineralized wastes being periodically discharged into the high-quality pond via the oil-skimmer pond, resulting in severe $\mathrm{pH}$ fluctuations. The problem has since been corrected, according to Hayden powerplant personnel (written commun., 1981).

The high-quality pond had the best water quality of any of the ponds, as defined by the lowest values for specific conductance and boron. The average specific conductance of the pond water was $863 \mu \mathrm{mhos} / \mathrm{cm}$ and the average boron concentration was $1,400 \mu \mathrm{g} / \mathrm{L}$. The pond contained high-quality effluents from the wastewater concentrator and from high-quality wastes. The water quality was relatively constant, deviating only slightly about the mean; for example, the deviation about the mean for specific conductance was about $150 \mu \mathrm{mhos} / \mathrm{cm}$ and for boron was about $400 \mathrm{\mu g} / \mathrm{L}$. The October 1979 sample from this pond had the lowest pH--6.8--and was affected by the same factors that lowered the $\mathrm{pH}$ in the oil-skimmer pond. Large variations in water quality of the high-quality pond are not expected in the future unless there is a spill or the inflow is altered.

Raw-water storage pond no. 1 has about the same water quality as the Yampa River, its source. The water quality of the pond varies less than that of the stream because the larger storage capacity of the pond acts as a buffer. The average specific conductance of the pond was $326 \mu \mathrm{mhos} / \mathrm{cm}$ and the average concentration of boron was $85 \mu \mathrm{g} / \mathrm{L}$. The March 1979 sample from this pond had the highest concentration of boron--140 $\mu \mathrm{g} / \mathrm{L}--$ whereas the sample from the Yampa River had $60 \mu \mathrm{g} / \mathrm{L}$. The reason for the difference is not known. No sample contained any analyzed constituent in excess of the Colorado Department of Health (1977b) standards for agricultural use of water.

Raw-water storage pond no. 2 , which was used as a fly-ash disposal pond from September 1965 to late 1978, contained water of the same quality as raw-water storage pond no. 1 from December 1978 through October 1979. While pond no. 2 was being used as an ash-disposal pond, leakage probably resulted in a plume of leachate moving downgradient from the pond. The movement, extent, and quality of this plume are not known. The concentrations of boron and the specific conductance of water in the plume would have been higher than those in the ambient ground water, 
but their values are not known. The plume would have caused boron to be adsorbed onto the clays and silts in the aquifer. Desorption of boron from the aquifer could have resulted in higher than ambient concentrations of boron in the ground water after the plume was probably displaced by leakage from the pond in late 1978.

Hayden powerplant personnel (oral and written communs., 1980) stated that the plume of water which originated when raw-water storage pond no. 2 was used for fly-ash disposal is presently underlying the Hayden powerplant. They also stated that the values of specific conductance and concentrations of boron in the plume are about the same as the values of specific conductance and concentrations of boron in the evaporation, the intermediate-quality, the oil-skimmer, and the highquality ponds. While the rate of movement of this plume is not known, the Hayden powerplant personnel suggest that it may take years for the remnants of the plume to dissipate from the area of the Hayden powerplant.

The coal-pile runoff pond contains water only during periods of local runoff. Because it is dry most of the time, it was not sampled.

\section{Wells}

Wells were placed near the Hayden powerplant to monitor the effect of the ponds on the ground water. Wells HS-1 through HS-6 and FC-4 were used to monitor the effects of the evaporation pond; wells HS-8 through HS-13 were used to monitor the effects of the intermediate-quality, the oil-skimmer, and the high-quality ponds; wells HS-15 and HS-16 were used to monitor the effects of the raw-water storage ponds; and well HS-18 was used to monitor the effects of the coal pile and the coal-pile runoff pond. The same groupings of wells are used in the discussion of how the movement and quality of water are affected by the powerplant. The relationships of specific conductance and boron with time in selected wells are shown in figures 8 and 9 .

Analyses of the water from wells HS-1 through HS-6 and FC-4 downgradient from the evaporation pond determined the following water-quality parameters and their average values: Specific conductance, $1,220 \mu \mathrm{mhos} / \mathrm{cm}$; boron, 1,200 $\mu \mathrm{g} / \mathrm{L}$; iron, $26 \mu \mathrm{g} / \mathrm{L}$; manganese, $250 \mu \mathrm{g} / \mathrm{L}$; and selenium, $3 \mu \mathrm{g} / \mathrm{L}$. The concentrations of iron in water samples from wells HS-1 through $\mathrm{HS}-6$ and $\mathrm{FC}-4$ probably are not related to the concentrations of iron in the ambient ground water or the evaporation pond, but are related to the reduction-oxidation potential in ground water. In an oxidizing environment, iron ions will be precipitated; in a reducing environment, the ions can be leached from the surrounding soil or transported by the ground water. The concentrations of iron in the wells were lower than the Colorado Department of Health (1977b) agricultural water-use standard of $200 \mu \mathrm{g} / \mathrm{L}$ and generally declined during the study. The concentrations of manganese generally exceeded the wateruse standard of $200 \mathrm{\mu g} / \mathrm{L}$ during the initial samplings and then declined to values lower than the standard during subsequent samplings. The water sample in well FC-4 had the lowest average concentration of manganese--30 $\mu \mathrm{g} / \mathrm{L}$. 


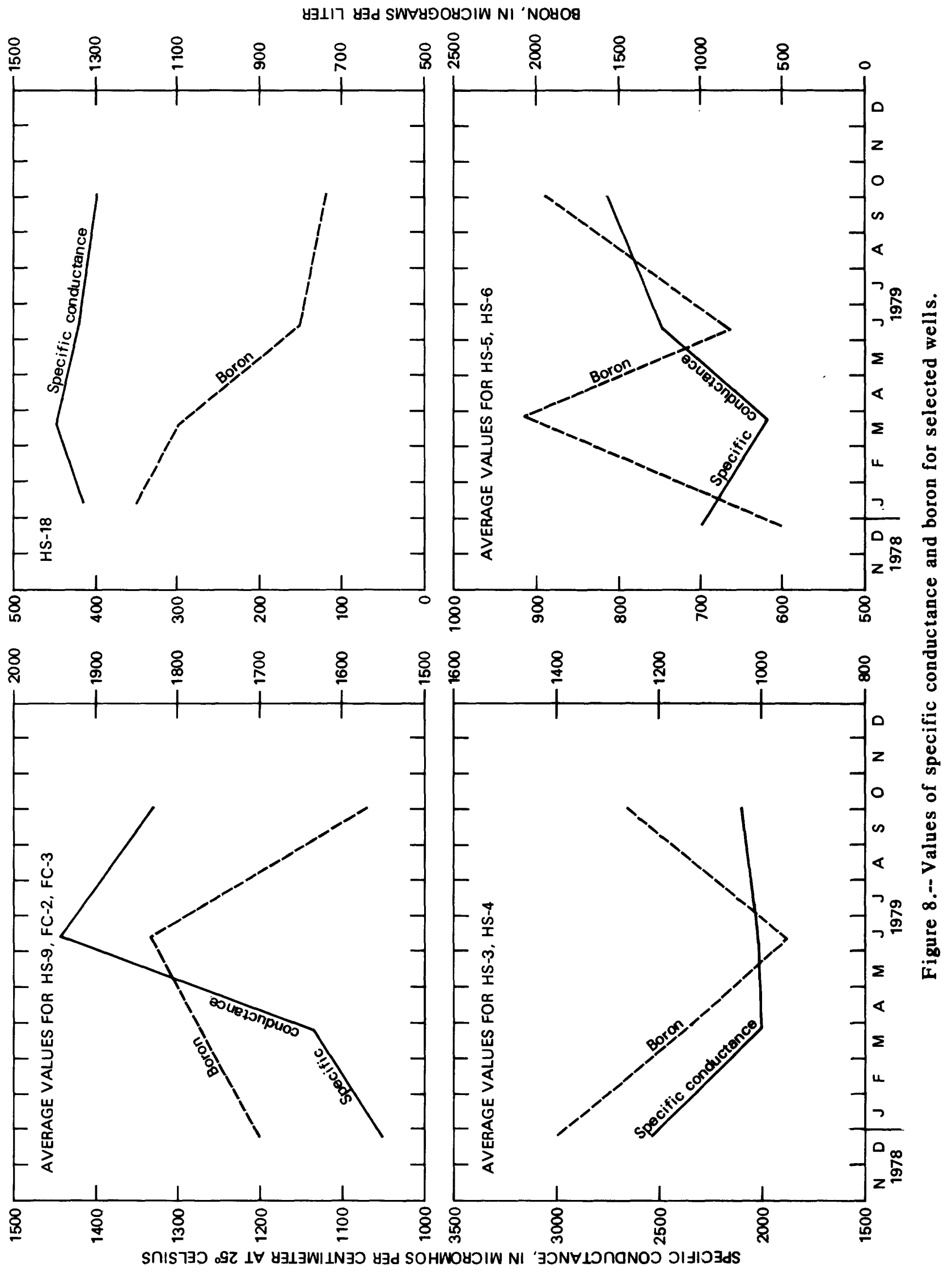




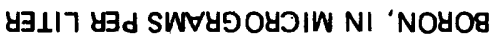
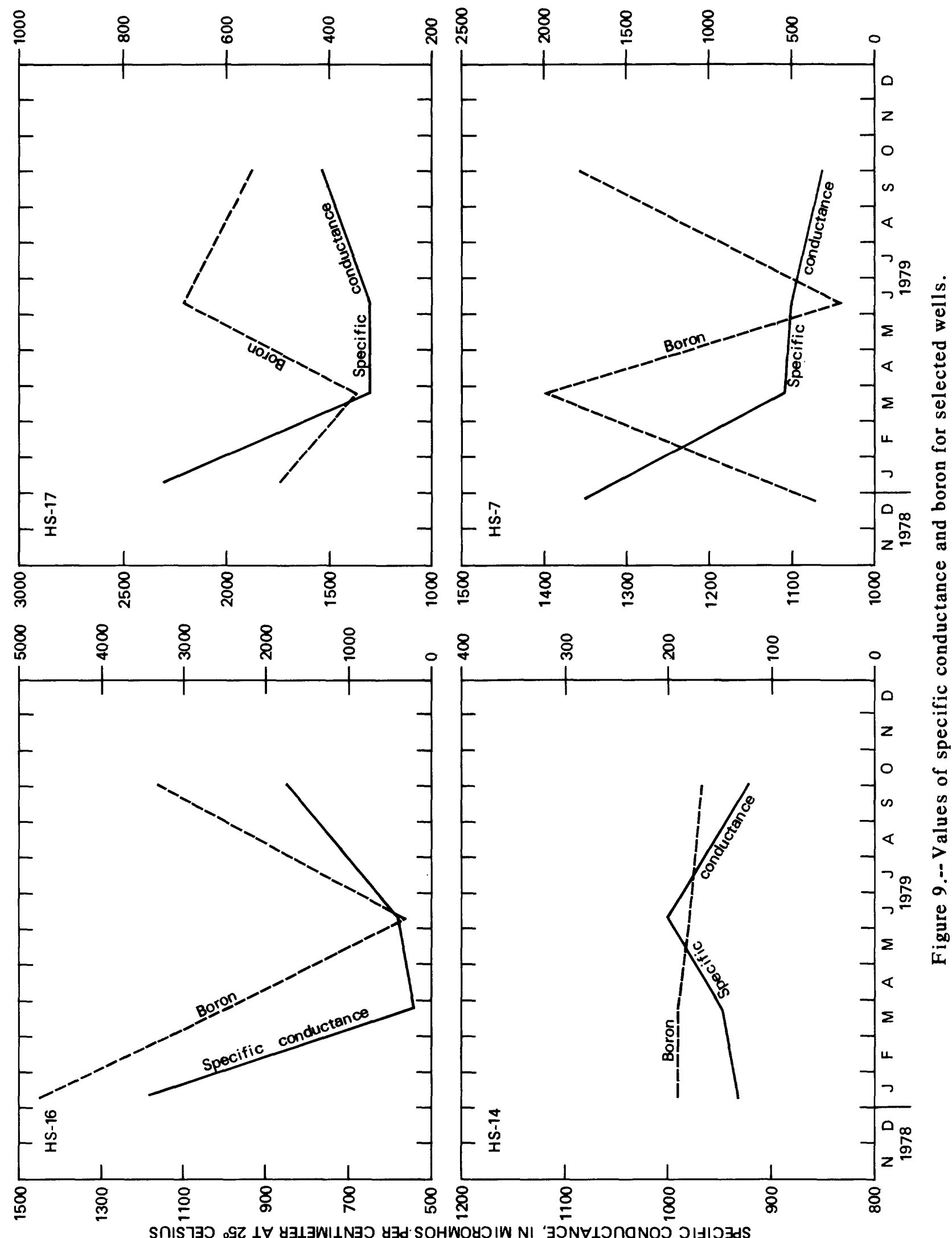
The ground-water-flow system in the area of the evaporation pond is not a simple system receiving water only from the pond and ambient ground water. This is evident by the values of specific conductance of the water in wells HS-5 and HS-6 and, to a lesser degree, in wells HS-1, HS-2, and FC-4. The values at times were lower than those of either the evaporation pond or the ambient ground water. These anomalous values probably are due to local ground-water recharge from rainfall, snowmelt, runoff from the plant, or leakage from the raw-water storage ponds.

Analyses of water samples from wells HS-8 through HS-13 and FC-1 through FC-3 downgradient from the intermediate-quality, the high-quality, and the oil-skimmer ponds determined the following water-quality parameters and their average values: Specific conductance, 1,170 $\mu \mathrm{mhos} / \mathrm{cm}$; boron, 1,600 $\mu \mathrm{g} / \mathrm{L}$; iron, $34 \mu \mathrm{g} / \mathrm{L}$; manganese, $92 \mu \mathrm{g} / \mathrm{L}$; and selenium, $6 \mu \mathrm{g} / \mathrm{L}$. All samples collected from wells HS-8 through HS13 and FC-1 through FC-3 contained boron in excess of the Colorado Department of Health (1977b) standards for agricultural use of water, except for the December 1978 samples from wells HS-8 and FC-1 and the June 1979 samples from well HS-11. The lower concentrations of boron in these samples probably were due to recharge resulting from snowmelt and rainfall runoff. Well HS-11 is downgradient from runoff-retention pond no. 2, and during the June 1979 sampling period the pond contained water. Wells $\mathrm{HS}-8$ and $\mathrm{FC}-1$ probably receive local recharge from runoffretention pond no. 1. Analyses of water samples from wells HS-8 through HS-13 and FC- 1 through FC-3 indicate that the intermediate-quality, the oil-skimmer, and the high-quality ponds were probably leaking. Boron concentrations in water from the wells were higher than in the ambient ground water and approached the concentrations of boron in the water from the ponds. The boron concentrations in the ground water downgradient from the intermediate-quality, the oil-skimmer, and the highquality ponds were therefore indicators the ponds were leaking.

Well HS-7 was drilled to monitor the effects of the evaporation, the intermediate-quality, the oil-skimmer, and the high-quality ponds. The average values of water-quality parameters for the water sample from well HS-7 were: Specific con-

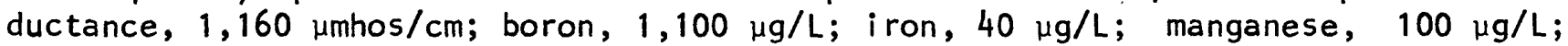
and selenium, $4 \mu \mathrm{g} / \mathrm{L}$. These results were compatible with the data on the wells monitoring the evaporation pond and the intermediate-quality, the oil-skimmer, and the high-quality ponds.

Wells HS-15 and HS-16 were drilled to monitor the effects of the raw-water storage ponds on the ground water. Raw-water storage pond no. 2 had been filled with fly ash prior to 1978, but was cleaned, reconditioned, and filled with Yampa River water prior to the January 1979 sampling. Before reconditioning, the pond probably recharged the alluvium penetrated by well HS-15 with water having a high specific conductance and a high boron concentration, possibly from the plume described previously. After the pond was filled with Yampa River water, infiltrate slowly leached boron from the soil, resulting in a lower boron level in the March, June, and October 1979 samples. This reduction in the concentration of boron in the water from well HS-15 will probably continue until the soil is in equilibrium with the raw water, which contains about $100 \mu \mathrm{g} / \mathrm{L}$ of boron. The Yampa River water infiltrating from the raw-water storage ponds also lowered the specific conductance of the water from well HS-15 to nearly that of the river water. 
Well HS-16 did not react as quickly to the change in source of recharge as did well HS-15, probably because the aquifer penetrated is less permeable. Only about $4 \mathrm{ft}$ of the aquifer is saturated, and this well yields less than 0.5 gal of water in 2 to 3 hours. The concentrations of boron in the water samples from well HS-16 have varied considerably, from $4,700 \mu \mathrm{g} / \mathrm{L}$ in January 1979 , to $300 \mu \mathrm{g} / \mathrm{L}$ in June 1979, and to $3,300 \mu \mathrm{g} / \mathrm{L}$ in October 1979. Probably the high level of boron in the January and October samples was due to seepage from the old fly-ash disposal pond or to boron being leached from the aquifer.

The concentrations of manganese in the water from well HS-16 generally decreased as the sampling progressed. The concentration of iron in the water sample from well HS-16 probably is related to a reduction-oxidation potential in the ground water, as explained in the section on wells HS-1 through HS-6 and FC-4. In the water from well HS-16, the average concentration of selenium $(12 \mu \mathrm{g} / \mathrm{L})$ was higher than that in any other wells sampled. One-half of the samples from well HS-16 exceeded the Colorado Department of Health (1977b) standards for agricultural use and drinking water.

Well HS-17 was drilled in a spoils pile where coal and materials remaining from plant construction were buried. At present (1980), coal is buried upgradient, west of the well. Average values of water-quality parameters for well HS-17 were: Specific conductance, $1,620 \mu \mathrm{mhos} / \mathrm{cm}$; boron, $520 \mu \mathrm{g} / \mathrm{L}$; iron, $600 \mu \mathrm{g} / \mathrm{L}$; manganese, $1,400 \mu \mathrm{g} / \mathrm{L}$; and selenium, $\mu \mathrm{g} / \mathrm{L}$. The water samples smelled of hydrogen sulfide $\left(\mathrm{H}_{2} \mathrm{~S}\right)$ which is an indication of reducing conditions in the well. The $\mathrm{H}_{2} \mathrm{~S}$ probably is derived from the decay of coal buried in the spoils pile. The pH of the water samples from this well remained constant at about $7.3--$ the lowest of any of the wells sampled. Well HS-17 probably is an indicator of the quality of ground water downgradient from the spoils pile and, therefore, cannot be used to define the ground-water quality in other areas.

Well HS-18 was drilled to monitor the effects of the coal pile and the coalpile runoff pond. Average values of selected water-quality parameters for well HS-18 were: Specific conductance, $420 \mu \mathrm{mhos} / \mathrm{cm}$; boron, $960 \mu \mathrm{g} / \mathrm{L}$; iron, $43 \mu \mathrm{g} / \mathrm{L}$; manganese, $210 \mu \mathrm{g} / \mathrm{L}$; and selenium, $4 \mu \mathrm{g} / \mathrm{L}$. The value for specific conductance and the boron concentration suggest that the well is receiving recharge from a water source low in specific conductance and high in boron concentration in relation to the ambient ground water. Two possible sources of this recharge are leakage from the raw-water storage ponds and the coal-runoff pond. Because the boron concentrations decreased as the sampling progressed, and because the coal-runoff pond is dry most of the time, the source of recharge was probably leakage from the rawwater storage ponds.

The concentrations of selenium in water from well HS-18 were lower than in the ambient ground water and about the same or less than in water from the rawwater storage ponds. Concentrations of iron were less than $100 \mu \mathrm{g} / \mathrm{L}$ and generally declined during the sampling period. The concentrations of manganese declined from $500 \mu \mathrm{g} / \mathrm{L}$ during the January 1979 sampling, were not detected in the March sampling, and increased to $140 \mu \mathrm{g} / \mathrm{L}$ in June. 
Seeps

Water from seeps HS-1 through HS-8 and the gravel-pit seep are indicators of the quality of the ground water downgradient from the Hayden powerplant. The combined average values of the water-quality parameters for seeps HS-1 through HS-8 were: Specific conductance, $943 \mu \mathrm{mhos} / \mathrm{cm}$; boron, $1,500 \mu \mathrm{g} / \mathrm{L}$; iron, $88 \mu \mathrm{g} / \mathrm{L}$; manganese, $28 \mu \mathrm{g} / \mathrm{L}$; and selenium, $4 \mu \mathrm{g} / \mathrm{L}$. The gravel-pit seep is discussed separately because it contains $\mathrm{H}_{2} \mathrm{~S}$, a reducing agent; therefore, the trace-element chemistry of the water from this seep differs from that of the other seeps, which do not contain $\mathrm{H}_{2} \mathrm{~S}$. The relationship of specific conductance and boron with time in selected seeps is shown in figure 10.

Water from the seeps varied in quality. Water from seep HS-5 had the lowest average boron concentration $(1,000 \mu \mathrm{g} / \mathrm{L})$, seep $\mathrm{HS}-3$ had the highest average boron concentration $(1,900 \mu \mathrm{g} / \mathrm{L})$, seep HS -5 had the lowest average manganese concentration $(5 \mu \mathrm{g} / \mathrm{L})$, and seep HS-4 had the highest average manganese concentration $(47 \mu \mathrm{g} / \mathrm{L})$. The average seep contained about seven times as much boron as did the ambient ground water. The average concentration of boron in the seeps is about two times the Colorado Department of Health (1977b) standard for agricultural use of water.

The gravel-pit seep smells of $\mathrm{H}_{2} \mathrm{~S}$ and locally is called a "sulfur spring." Two of the three samples from the seep contained manganese concentrations in excess of the 200- $\mathrm{g} / \mathrm{L}$ standard (Colorado Department of Health, 1977b) for agricultural use of water. The concentrations of other trace elements are lower than the standards.

\section{Discharge Weir}

The discharge weir is probably reacting to the leakage from the raw-water storage ponds. The values for specific conductance and concentrations of boron, iron, manganese, and selenium declined by at least one-half from the January 1979 to the October 1979 samplings. The January samples contained $20 \mu \mathrm{g} / \mathrm{L}$ of chromium, $15,000 \mu \mathrm{g} / \mathrm{L}$ of iron, $21 \mathrm{\mu g} / \mathrm{L}$ of nickel, $21 \mu \mathrm{g} / \mathrm{L}$ of selenium, and $60 \mu \mathrm{g} / \mathrm{L}$ of zinc, which were the highest concentrations from any sampling source in the study. The average values for the discharge weir were: Specific conductance, $900 \mu \mathrm{mhos} / \mathrm{cm}$; boron, 1,400 $\mathrm{g} / \mathrm{L}$; manganese, $130 \mu \mathrm{g} / \mathrm{L}$; and selenium, $13 \mu \mathrm{g} / \mathrm{L}$. An average value for iron is not relevant due to the large variation between the January to June 1979 sampling.

\section{Streams}

Sage Creek above the Hayden powerplant, the upper of the two sites located on Sage Creek, was sampled in March and June 1979 and was dry during the other sampling periods. Sage Creek at U.S. Highway 40, the lower site, was sampled in March, June, and October 1979. Sage Creek at the upper site had a higher specific conductance than the lower site, averaging 3,300 $\mu$ mhos $/ \mathrm{cm}$ versus $1,680 \mu \mathrm{mhos} / \mathrm{cm}$; higher manganese, $740 \mu \mathrm{g} / \mathrm{L}$ versus $140 \mu \mathrm{g} / \mathrm{L}$; lower boron, $240 \mu \mathrm{g} / \mathrm{L}$ versus $320 \mu \mathrm{g} / \mathrm{L}$; 


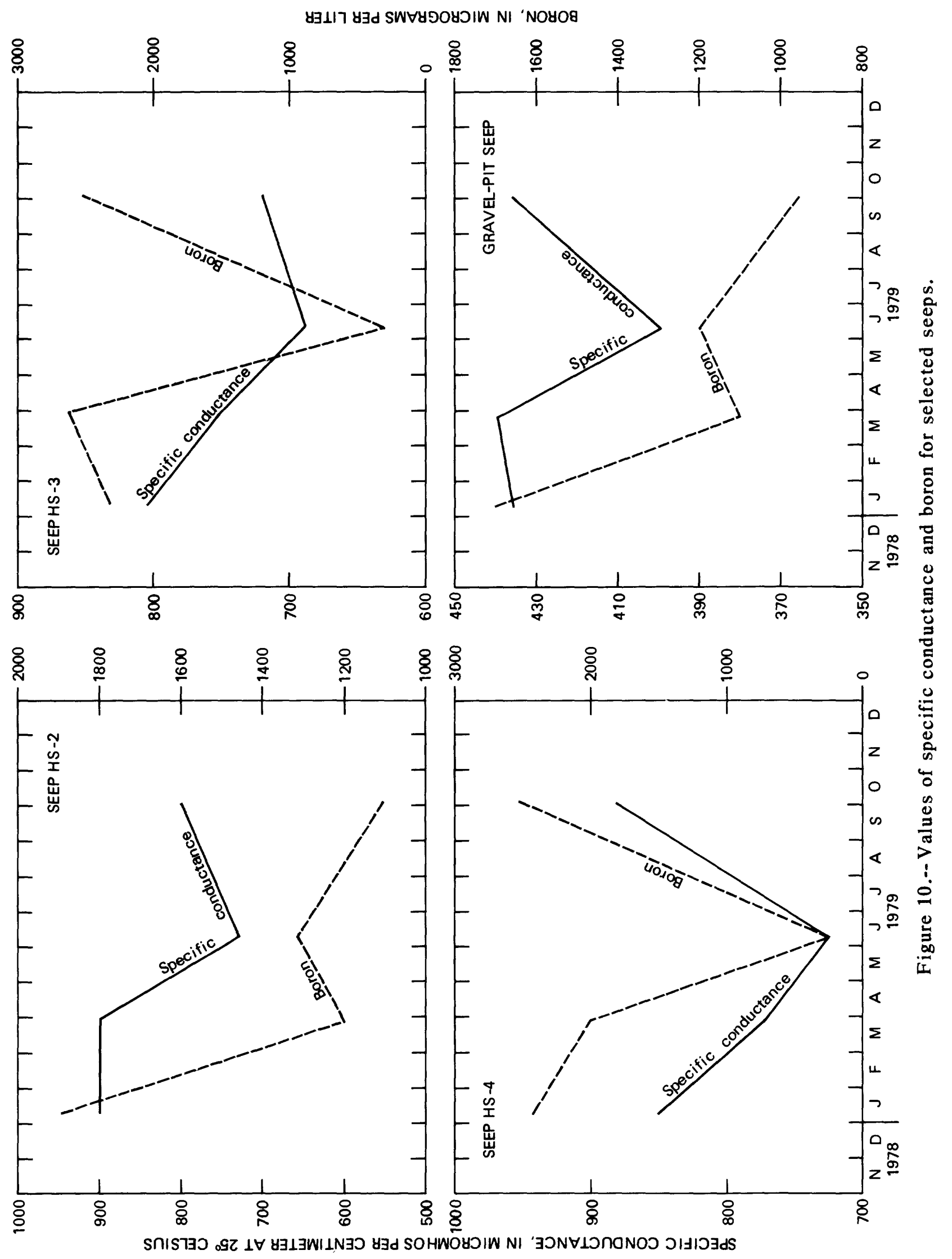


higher iron, $120 \mu \mathrm{g} / \mathrm{L}$ versus $70 \mu \mathrm{g} / \mathrm{L}$; and about the same average value of selenium, about $60 \mathrm{\mu g} / \mathrm{L}$. The March samples contained the highest concentrations of selenium collected at both sites on Sage Creek, $120 \mu \mathrm{g} / \mathrm{L}$ at the upper site and $110 \mu \mathrm{g} / \mathrm{L}$ at the lower site. These concentrations are about 11 to 12 times the standard for a water supply and 5 to 6 times the standard for agricultural use (Colorado Department of Health, 1977b). The selenium probably is not coming from the Hayden powerplant, but from some upstream source.

Water discharged from the Hayden powerplant affected Sage Creek by lowering the specific conductance and concentrations of iron and manganese; increasing the concentration of boron; and leaving the concentration of selenium essentially unchanged. Effluents from the powerplant entering Sage Creek had little effect on the Yampa River because the flow of Sage Creek averaged only about 0.2 percent of the Yampa River flow.

Four samples were collected at the streamflow-gaging station, Yampa River near Hayden, and one low-flow sample was collected for the Yampa River at Hayden. The Yampa River was sampled to determine the effects of the effluent from the Hayden powerplant on the river. The values of selected water-quality constituents at both sites were equal, within the error of analysis and sampling. Since lowflow conditions are the "worst case" in respect to the effect of effluents, at the present (1980), effluents from the Hayden powerplant are having no discernible effect on the Yampa River.

\section{GROUND-WATER MOVEMENT AND QUANTITY}

The direction of movement of the ambient ground water is not known but probably is about normal to the bedrock contours. The movement near the ponds can be depicted by drawing flow lines normal to the water-table contours. Groundwater flow lines in the immediate area of the Hayden powerplant for March 1979 are depicted on plate 6 . The flow lines are, in general, normal to the downgradient sides of the ponds.

Empirical methods for estimating hydraulic conductivity, $K$, were used because boundary conditions near the observation wells precluded the use of aquifer testing by direct means. The method described by Robson (1978), which used an empirical correlation of particle grain size and sorting data obtained from core samples to estimate $K$, was applied to samples of the aquifer. The derived value of $K$ was $6 \mathrm{ft} / \mathrm{d}$. The value of $K$ is about one-seventh the average value of $K$ for sand and gravel aquifers (McWhorter and Sunada, 1977) but was within the range of values given for sand and gravel aquifers.

Two additional methods were applied to estimate $K$--the slug method and visual estimation by experienced personnel. In the slug method, a quantity of water is introduced into the well, the rate of decline of the water level in the well is measured, and $K$ is estimated. The values of $K$ obtained by these two methods ranged from 4 to $60 \mathrm{ft} / \mathrm{d}$. The apparent difficulties in application of the slug and visual-estimation methods are the small diameter of the wells in relation to their depth, the wide range of particle sizes in the aquifer, and the horizontal layering of clay. 
Because estimates of the $K$ values ranged widely using these three techniques, the leakage rate from the evaporation pond could not be calculated. A chemical mass-balance equation was then used to estimate the proportion of ground-water flow downgradient from the evaporation pond that might originate as leakage from the pond. The data from March 1979 were chosen for the mass-balance equation because the local hydrologic conditions were relatively stable, and the water quality in the evaporation pond and downgradient wells were reasonably constant. The saturated thickness map was drawn (pl. 7) to verify the apparent stability of the ground-water flow downgradient from the evaporation pond, and the map showed no apparent flow discontinuities.

The following mass-balance equations were applied to estimate the leakage from the evaporation pond:

$$
\begin{gathered}
q_{e p}+q_{u g}=q_{p}, \\
\text { and } \\
B_{e p} \times q_{e p}+B_{u g} \times q_{u g}=B_{p} \times q_{p},
\end{gathered}
$$

where:

$q_{e p}=$ leakage from the evaporation pond, in cubic feet per second;

$q_{u g}=$ ambient ground-water flow, in cubic feet per second; $q_{p}=$ flow past the downgradient face of the evaporation pond, in cubic feet

$B_{e p}=$ boron concentration in the evaporation pond, in $\mu \mathrm{g} / \mathrm{L}$;

$B_{u g}=$ boron concentration in the ambient ground water, in $\mu \mathrm{g} / \mathrm{L}$; and

$B_{p}=$ boron concentration in the ground water passing the downgradient face of the evaporation pond (the average of analyses from wells HS-3 and $\mathrm{HS}-4)$, in $\mu \mathrm{g} / \mathrm{L}$.

The following knowns:

$$
\begin{aligned}
& B_{e p}=3,900 \mu \mathrm{g} / \mathrm{L}, \\
& B_{u g}=190 \mu \mathrm{g} / \mathrm{L}, \text { and } \\
& B_{p}=1,150 \mu \mathrm{g} / \mathrm{L}
\end{aligned}
$$

are substituted in equations 1 and 2 , which are then solved to yield:

$$
q_{u g} \simeq 2.5 q e p
$$

Substituting into equation 1 yields:

$$
\begin{aligned}
q_{e p}+2.5 q_{e p} & =q_{p}, \\
3.5 q_{e p} & =q_{p}, \\
q_{e p} & =0.29 q_{p} .
\end{aligned}
$$


According to the above results, the leakage from the evaporation pond is about one-fourth of the ground-water flow past the downgradient face of the evaporation pond. This calculation of leakage is subject to the following assumptions:

1. In the mass-balance equations:

a. Boron is a conservative tracer, and

b. The concentrations of boron in the water samples from the pond and well are the average concentrations present in the pond and aquifer.

2. The only source of boron higher in concention than the ambient concentratration is the pond upgradient from the flow section.

3. The Lewis Shale is not a source of boron because it is not an aquifer in this area.

The same method and assumptions were used to estimate what percent of groundwater flow past a section along the north and west faces of the intermediatequality, the oil-skimmer, and the high-quality ponds is leakage from the ponds. Calculations using the equations indicate that during the same period--March 1979 --the entire flow through the section was leakage from the ponds. The concentration of boron in the March sample from the intermediate-quality pond (the largest pond) was the lowest of all the samples. The concentration of boron may have been low only for a short time when conditions were not average or stable. If the average concentration of boron was used in the calculations, then about threefourths of the flow past the section would be leakage from the intermediatequality, oil-skimmer, and high-quality ponds. To verify the results, October 1979 conditions were analyzed, and about three-fourths of the flow was calculated to be leakage from the ponds. Based on these data and calculations, the best estimate is that about three-fourths or more of the flow through the section is leakage from the ponds.

\section{CONCLUSIONS}

Water-quality data from the evaporation pond, the effluent inflow, and the bottom material indicate that the specific conductance and the concentration of boron in the evaporation pond probably will continue to increase and that the values of these parameters will fluctuate seasonally due to precipitation and evaporation. The only sample of the effluent disposed of in the evaporation pond contained a selenium concentration of about $220 \mathrm{\mu g} / \mathrm{L}$. By comparison, the concentrations of selenium in the pond water, the bottom materials, or the downgradient ground water were less than $20 \mu \mathrm{g} / \mathrm{L}$. Further study is needed to determine why these concentrations were drastically lower. The intermediate-quality, the oilskimmer, and the high-quality ponds were relatively stable with respect to water quality and will probably remain so unless the inflows are changed chemically. The raw-water storage ponds reflect the water quality of the Yampa River, which is their source, and provide water low in boron concentration and low in specific conductance to the local ground water. 
Analyses of the quality of water from the observation wells downgradient from the Hayden powerplant indicate that concentrations of boron in the ground water downgradient from the effluent ponds have increased to an average concentration that exceeds the Colorado Department of Health (1977b) standards for agricultural use of water. The boron concentration in water from wells HS-1 through HS-13 and FC-1 through FC-4 probably will not decrease below these standards in the near future.

Data from wells HS-15, HS-16, and HS-18 indicate the raw-water storage ponds are leaking. This leakage is resulting in boron concentrations of less than $500 \mathrm{\mu g} / \mathrm{L}$, except in well HS-16 where less than $4 \mathrm{ft}$ of the aquifer is saturated, and the water movement apparently is slower than at the other monitor wells. The trend for these concentrations is to decrease as the boron is leached from the unsaturated zone below the ponds.

Water from nine sampled seeps are the best indicators of the quality of the ground water downgradient from the Hayden powerplant. The average concentration of boron in the water from these seeps was $1,500 \mu \mathrm{g} / \mathrm{L}$, about two times the Colorado Department of Health (1977b) standard for agricultural use of water. Concentrations of boron in the seeps vary seasonally, being lowest during the spring (highest recharge), and highest during the fall and winter (lowest recharge).

The discharge weir, which was in use until 1976 as part of a system to dispose of effluents, is now discharging ground water that is recovering from the effects of the effluents. The concentrations of selected trace elements in the water generally declined during the study. This decrease in the concentration of trace elements probably will continue, because the raw-water storage ponds are the major source of recharge to the ground water discharging over the weir. The discharge weir is also the largest single ground-water discharge point downgradient from the Hayden powerplant. The average flow over the weir is about $0.40 \mathrm{ft}^{3} / \mathrm{s}$.

The effect on Sage Creek of the effluents from the Hayden powerplant was to lower the specific conductance and the concentrations of iron and manganese, to increase the concentration of boron, and to leave unchanged the concentration of selenium, as compared to the upstream water quality of Sage Creek. Sage Creek above the Hayden powerplant contained a high concentration of selenium during the March sampling- $-120 \mu \mathrm{g} / \mathrm{L}, 12$ times the standard for a water supply and 6 times the standard for agricultural use (Colorado Department of Health, 1977b). This selenium probably is not coming from the Hayden powerplant, but from some upstream source.

The Yampa River near Hayden (above the powerplant) and Yampa River at Hayden (below the powerplant) were sampled in October during low flow. Analysis of the samples indicates that effluents from the Hayden powerplant had no discernible effect on the Yampa River, due to the large volume of the Yampa River in relation to the volume of effluents from the Hayden powerplant. 
Two theories may be used to explain the high boron content and the high specific conductance of the water from wells and seeps downgradient from the evaporation, the intermediate-quality, the oil-skimmer, and the high-quality ponds. One theory is that all of the ponds are leaking; the second theory, suggested by the Hayden powerplant personnel (oral and written commun., 1980), is that a plume of contaminants has resulted from leakage of raw-water storage pond no. 2 when it was used for fly-ash disposal. The second theory also explains the high boron content and low specific conductance of the water from wells HS-15 and HS-18.

The concept of the leaking ponds or the plume theory can both be supported by water-quality data from wells downgradient from the evaporation, the intermediatequality, the oil-skimmer, and the high-quality ponds. The water-level contours near these ponds tend to conform to the shape downgradient from the ponds, with a higher ground-water level nearest the ponds. Therefore, those water-level contours tend to support the concept that the ponds are leaking. The specific conductance in water samples from wells HS-15 and HS-18, which are downgradient from the rawwater storage ponds, declined during the study to a value near the specific conductance of the water in the raw-water storage ponds and to about one-half the value in the ambient ground water, which indicates that the raw-water storage ponds are leaking. The raw-water storage ponds and the evaporation, the intermediate-quality, the oil-skimmer, and the high-quality ponds are lined with the same type of locally obtained clay and are of similar construction. The raw-water storage ponds are lined with $5 \mathrm{ft}$ of clay, and the evaporation, intermediate-quality, oil-skimmer, and high-quality ponds are lined with $2 \mathrm{ft}$ of clay. If the raw-water storage ponds are leaking, the conclusion is that all ponds probably are leaking.

Data from wells HS-15 and HS-18 indicated decreasing values of specific conductance and concentrations of boron in the ground water downgradient from the raw-water storage ponds. This tends to support the concept of a remnant plume of water high in specific conductance and high in boron concentrations moving downgradient from the raw-water storage ponds. That is, if the raw-water storage ponds were leaking during 1978 and 1979, they were probably leaking when raw-water storage pond no. 2 was used for fly-ash disposal, resulting in a plume with high specific-conductance values and high boron concentrations.

Seep HS-8 was dry in October 1979 which was interpreted by Hayden powerplant personnel as an indication of minimal leakage from the intermediate-quality pond. Seeps HS-3 and HS-4, also downgradient from the intermediate-quality pond, were not dry during October 1979 and had concentrations of boron of 2,500 $\mu \mathrm{g} / \mathrm{L}$. The October flows and high concentrations of boron of seeps HS-3 and HS-4 indicate that the leakage from the intermediate-quality pond may be significant. The data for seeps HS-3, HS-4, and HS-8 during October 1979 is, however, inconclusive to quantitatively define leakage from the intermediate-quality pond.

Flow rates were calculated using a mass-balance equation to obtain the percent of the ground water leaking from the ponds. Calculations using the massbalance equations were based on the assumption that the ponds were the only source of water containing high concentrations of boron. About one-fourth of the flow past a section downgradient from the evaporation pond was computed to be leakage from the pond. About three-fourths of the flow past a section downgradient from the intermediate-quality, the oil-skimmer, and the high-quality ponds was computed to be leakage from the ponds. 
Although both theories can be used to explain the high concentrations of boron and the high values of specific conductance, the available data tend to support the leaking-ponds theory or a combination of the leaking-ponds and plume theories. To completely isolate the effects of the pond leakage from the plume would require further study, which would require the drilling of additional wells upgradient of the powerplant and wells between the raw-water storage ponds and the other ponds. In addition, hydraulic conductivity and porosity of the alluvium must be determined to facilitate reliable estimates of leakage rates from the ponds and the rate of movement of the plume.

\section{REFERENCES}

Colorado Department of Health, 1977a, Primary drinking water regulations for the State of Colorado: Denver, Water Quality Control Division, $60 \mathrm{p}$.

1977b, Proposed water quality standards for Colorado (draft no. 9; November 17, 1977): Denver, Colorado Department of Health, 51 p.

Gough, L.P., Shacklette, H.T., and Case, A. A., 1979, Element concentrations toxic to plants, animals, and man: U.S. Geological Survey Bulletin 1466, $65 \mathrm{p}$.

Hem, J. D., 1970, Study and interpretation of chemical characteristics of natural water (2d ed.): U.S. Geological Survey Water-Supply Paper 1473, 363 p.

Holland, W. F., and Jones, B. F., 1978, Potential for ground water contamination by trace elements in ponded ash and scrubber sludge, in American Society of Civil Engineers Spring Convention and Exhibit, Pittsburgh, April 24-28, 1978, Proceedings: $24 \mathrm{p}$.

McWhorter, D. B., and Sunada, D. K., 1977, Ground-water hydrology and hydraulics: Fort Collins, Colo., Water Resources Publications, 258 p.

National Academy of Sciences and National Academy of Engineering, 1973 [1974], Water quality criteria, 1972: Washington, D.C., U.S. Government Printing Office, $594 \mathrm{p}$.

Phung, H. T., Lund, L. J., Page, A. L., and Bradford, G. R., 1979, Trace elements in fly ash and their release in water and treated soils: Journal of Environmental Quality, v. 8, no. 2, p. 171-175.

Robson, S. G., 1978, Application of digital profile modeling techniques to ground water solute transport at Barstow, California: U.S. Geological Survey WaterSupply Paper 2050, 26 p.

U.S. Department of Agriculture, 1954, Saline and alkali soils, Agriculture handbook no. 60: Washington, D.C., U.S. Government Printing Office, $256 \mathrm{p}$.

1957, Soils, the year book of agriculture, 1957: Washington, D.C., U.S. Government Printing office, $745 \mathrm{p}$.

U.S. Environmental Protection Agency, 1976a, National interim primary drinking water regulations: U.S. Environmental Protection Agency 570/9-76-003, $159 \mathrm{p}$. 1976b, Interim primary drinking water regulations--Promulgation of regulations on radionuclides: Federal Register, v. 41, no. 133, Friday, July 9 , 1976, Part 11, p. 28402-29409.

1977, National secondary drinking water regulations: Federal Register, v. 42 , no. 62, Thursday, March 31, 1977, Part 1, p. 17143-17147.

Wentz, D. A., and Steele, T. D., 1980, Analysis of stream quality in the Yampa River basin, Colorado and Wyoming: U.S. Geological Survey Vater-Resources Investigations 80-8, 161 p.; available only from U.S. Department of Commerce, National Technical Information Service, Springfield, VA 22161, as report PB-81 108 904. Paper copy $\$ 14$; microfiche $\$ 3.50$. 


\section{SYSTEMS OF LOCATING AND NUMBERING WELLS AND SPRINGS}

Two systems are used to locate and number wells and springs. One system (fig. 11) uses the 14-character code of the U.S. Bureau of Land Management's landsubdivision system. The first character is an S, which indicates that the well or spring is located in the area covered by the Sixth Principal Meridian. The next letter denotes the quadrant formed by the intersection of the base line (parallel) with the principal meridian. The quadrants are designated $A, B, C$, or $D$ in a counterclockwise manner with the northeast quadrant being $A$. The first three numbers designate the township, the next three designate the range, and the last two designate the section. Each section is then divided into quarters designated $A, B$, $C$, or $D$ in a counterclockwise rotation, with the northeast quarter being $A$. This is done again for the quarter-quarter section and the quarter-quarter-quarter section. The three letters following the number designation of township, range, and section indicate the well or spring position first in the quarter section, then in the quarter-quarter section, and then in the quarter-quarter-quarter section. The final number is the order in which the well or spring in the designated quarterquarter-quarter section was inventoried. A well or spring numbered SB00608717BAA1 would be the first one located in the NWt $\frac{1}{4}$ EE $\frac{1}{4} N E \frac{1}{4}$ sec. $17, T .6 \mathrm{~N}, \mathrm{R} .87 \mathrm{~W}$.

The second system is a 15-digit number derived from latitude and longitude. The first six digits represent degrees, minutes, and seconds of latitude, and the next seven digits represent degrees, minutes, and seconds of longitude. The remaining two digits indicate the sequence in which wells or springs with the same latitude-longitude designations were inventoried. 


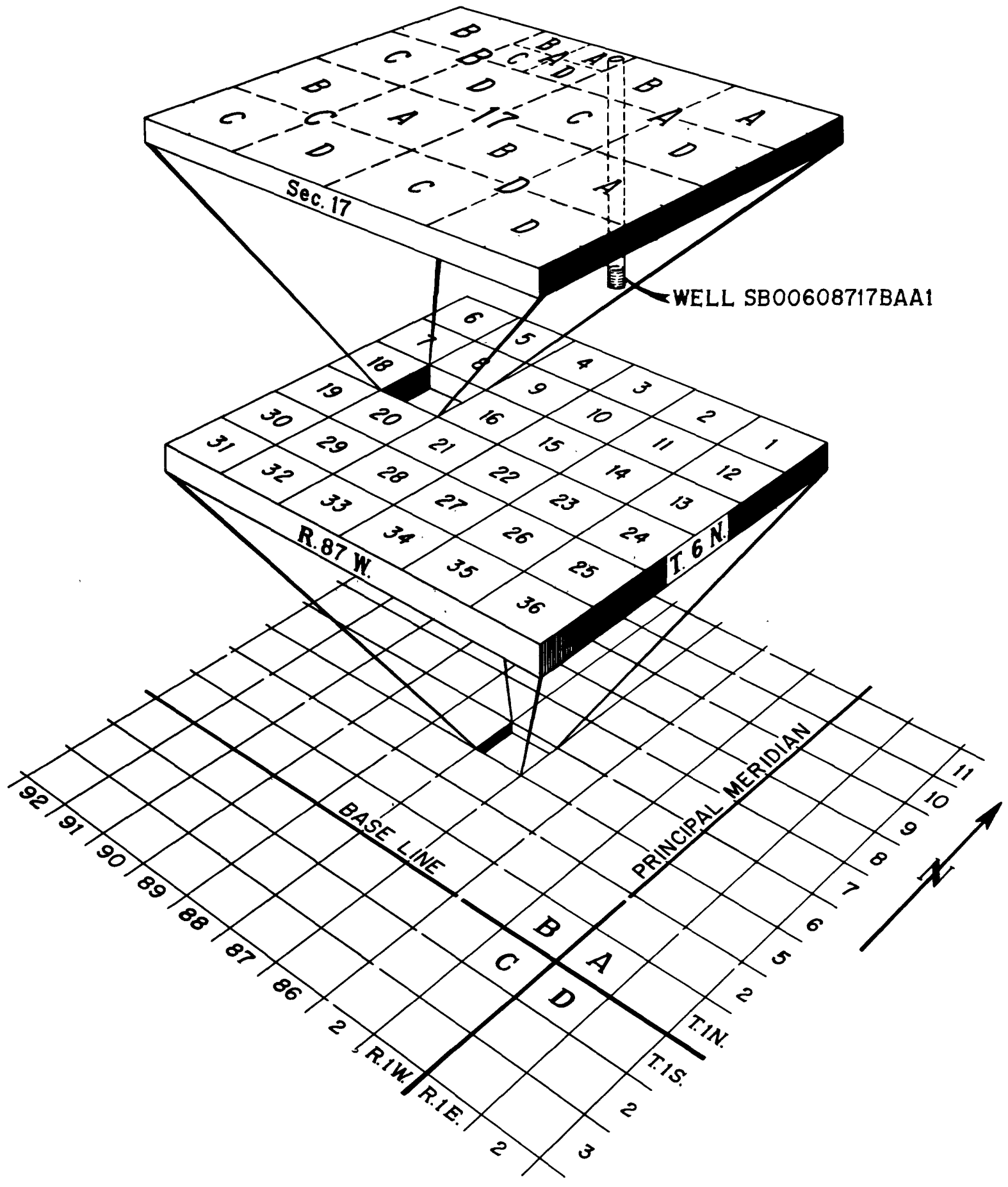

Figure 11.- Diagram showing system of locating and numbering wells and springs. 
WATER-QUALITY DATA

Next jayje a yis 


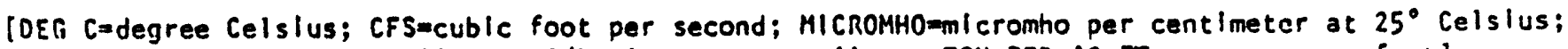
MG/L-milligram per liter; UG/L-microgram per liter; TON PER AC-fT=ton per acre-foot]

DATE

PI UE

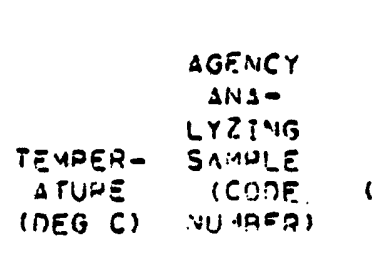

SDE-

CIF!C

M!CT-

Aine
(aicolos

जUDS)

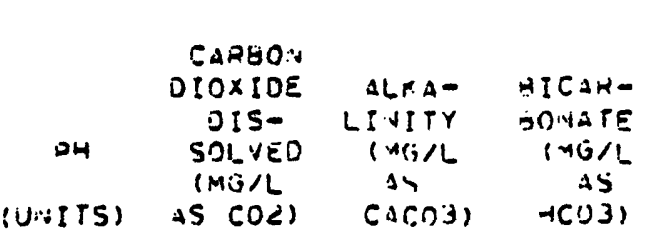

NITRO-

GEN,

$\therefore U ?+N i 1\}$ Dर $\{-i j$,

(1) IS- Dis-

SHIVEA SULVEO

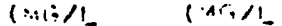

म5 तो 45 I)

JAN $1 \ngtr 79$

\begin{tabular}{|c|c|c|c|c|c|c|c|c|c|}
\hline$\underset{A A R}{11} \cdots$ & 0900 & $\infty$ & 800211 & 940 & 7.3 & -- & 330 & $-\infty$ & 18 \\
\hline $25 \ldots$ & 1325 & 10.0 & 500211 & 350 & 7.7 & $\infty$ & 330 & - & 13 \\
\hline $\begin{array}{l}\text { JUN } \\
12 \ldots . . \\
\text { or.T }\end{array}$ & 1535 & 14.0 & 80020 & 1000 & 7.6 & 13 & 260 & 320 & 20 \\
\hline $03 \ldots$ & 1130 & 11.0 & d0020 & 92.5 & 7.5 & $\infty$ & 360 & $-\infty$ & \\
\hline
\end{tabular}

\begin{tabular}{|c|c|c|c|c|c|c|c|c|c|c|}
\hline DATE & $\begin{array}{l}\text { PUOS- } \\
\text { PHIMISS, } \\
\text { OIS- } \\
\text { SULVEO } \\
\text { inG/L } \\
\text { AS PI }\end{array}$ & $\begin{array}{l}\text { PMOS- } \\
\text { PMURUS, } \\
\text { DQPIHI), } \\
\text { OIS- } \\
\text { SULVFI } \\
\text { (MG/L } \\
\text { ASPI }\end{array}$ & $\begin{array}{l}\text { MARn- } \\
\text { NESS } \\
\text { IMG/L } \\
\text { AS } \\
\text { CACOB) }\end{array}$ & 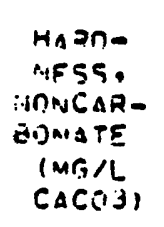 & $\begin{array}{l}\text { CALELIJA } \\
\text { PIS- } \\
\text { SOLVED } \\
\text { (HACIAL } \\
\text { AS CA) }\end{array}$ & 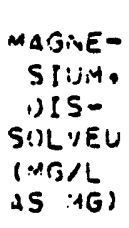 & 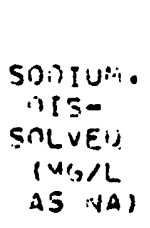 & 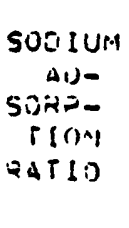 & 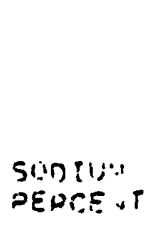 & 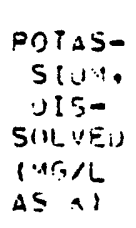 \\
\hline 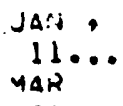 & $+79 \quad .10<0$ & .01 & $32 !$ & 0 & 64 & 40 & 90 & 2.2 & 37 & 3.0 \\
\hline ?א.... & .010 & .01 & $36 "$ & 29 & 13 & 43 & 90 & 2.1 & ذا. & 3.7 \\
\hline $\begin{array}{c}12 . \\
\text { OCT } \\
03 .\end{array}$ & -- & - & -- & - & -- & - & - & $\infty$ & - & \\
\hline
\end{tabular}

\begin{tabular}{|c|c|c|c|c|c|c|c|c|c|c|}
\hline DaTe & 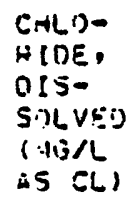 & $\begin{array}{l}\text { SILFATE } \\
\text { UISE } \\
\text { SOLVEO } \\
\text { IYG/L } \\
\text { AS SOUI }\end{array}$ & $\begin{array}{l}\text { FLUn- } \\
\text { DII:E: } \\
\text { nIS- } \\
\text { SHLVE? } \\
\text { (ArTLL } \\
\text { A.S F) }\end{array}$ & $\begin{array}{c}\text { STi.iCA, } \\
\text { CIS- } \\
\text { SnLVEn } \\
\text { r+1G/L } \\
\Delta 5 \\
\text { SIJ?I }\end{array}$ & $\begin{array}{l}\text { ADSENIC } \\
\text { JIS- } \\
\text { SULVEO } \\
\text { IUG/L } \\
\text { AS ASI }\end{array}$ & 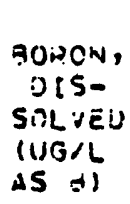 & 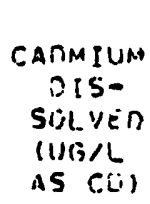 & $\begin{array}{l}\text { (HQU)- } \\
\text { HUU, } \\
U(S- \\
\text { SULVFO } \\
(1 G / ! \\
\Delta S \text { (R) }\end{array}$ & $\begin{array}{l}\text { CUPOE: } \\
\text { U!SE } \\
\text { SCLVE: } \\
\text { (IIIS! } \\
\text { NS Ci:I }\end{array}$ & 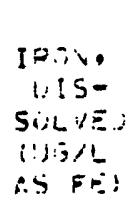 \\
\hline \multicolumn{11}{|c|}{$1 \ngtr 79$} \\
\hline 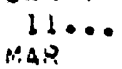 & 22 & 90 & .7 & 16 & 1 & 190 & 2 & i & 3 & 20 \\
\hline JuN... & 23 & 180 & .8 & 15 & - & 190 & - & 0 & - & 170 \\
\hline $12 \ldots$ & $\cdots$ & - & -- & 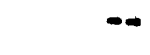 & $\cdots$ & 160 & $-\infty$ & -- & -- & 10 \\
\hline $03 \ldots$ & $-\infty$ & -- & - & - & - & 170 & - & 10 & -- & -- \\
\hline
\end{tabular}

JAN 1479

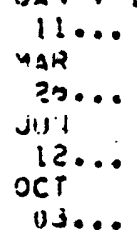

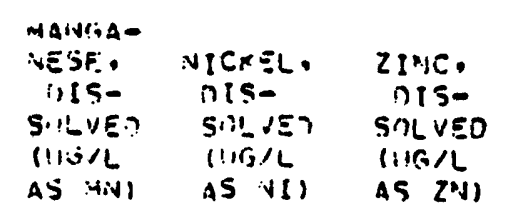

SELE-

Siluin.

ก. (5-

$\sin (\vee \tilde{E} !)$

lilis/le

AS SE)
SELE-

PII:je:

TOTIL

luG/L

AS SE)
SOL TOS, JUM OF CUNSTITHE:TS, ก!: Silt. V $\leq$ ? (MIS/) sol. I: DIS- METCURV SO1. IED मIS(ri):S SILVER PEN $\triangle C-F(1)$
.00 .43

- 
WATER-QUALITY DATA FOR BARNES WELL, HAYDEN POWERPLANT, HAYDEN, COLO.

\begin{tabular}{|c|c|c|c|c|c|c|c|c|c|c|}
\hline & TIME & $\begin{array}{l}\text { TEMPER- } \\
\text { ATURE }\end{array}$ & $\begin{array}{l}\text { SPE- } \\
\text { CIFIC } \\
\text { CONE } \\
\text { OUCT- } \\
\text { ANCE } \\
\text { IHICHO- }\end{array}$ & DH & $\begin{array}{l}\text { ALKA- } \\
\text { LINTTY } \\
\text { IIHIJ/L } \\
A S\end{array}$ & $\begin{array}{l}\text { PHOS- } \\
\text { PHURUS. } \\
\text { OTS- } \\
\text { SULVEU } \\
\text { IMG/L }\end{array}$ & $\begin{array}{l}\text { HARI) } \\
\text { INESS } \\
(A G / L \\
A S\end{array}$ & $\begin{array}{l}\text { HAHU- } \\
\text { NESS } \\
\text { NOHCAR- } \\
\text { HONATE } \\
\text { IMIJ/L }\end{array}$ & $\begin{array}{l}\text { CALCIHII } \\
\text { I)IS- } \\
\text { SULVFU } \\
\text { IMCAIL }\end{array}$ & $\begin{array}{l}\text { MAGNE- } \\
\text { SIUII. } \\
\text { HIS- } \\
\text { SULVEO } \\
\text { MG/L }\end{array}$ \\
\hline DATE & & (DEG C) & MHOSI & (UPIIS) & $\operatorname{cacos} 31$ & $\Delta S P I$ & $\operatorname{coc}(03)$ & $(\mathrm{CACO} 3)$ & $4 S C A 1$ & $\Delta S \quad H(j)$ \\
\hline JUN • & & & & & & & & & & \\
\hline${ }_{\text {oct }}^{13} \cdots$ & 1345 & 12.11 & 1461 & 9.3 & 290 & .0 .30 & 630 & 340 & 140 & 07 \\
\hline $03 \ldots$ & 1710 & 15.0 & 1000 & 7.6 & 250 & $-\infty$ & $-\infty$ & $-\infty$ & $-\infty$ & - \\
\hline
\end{tabular}

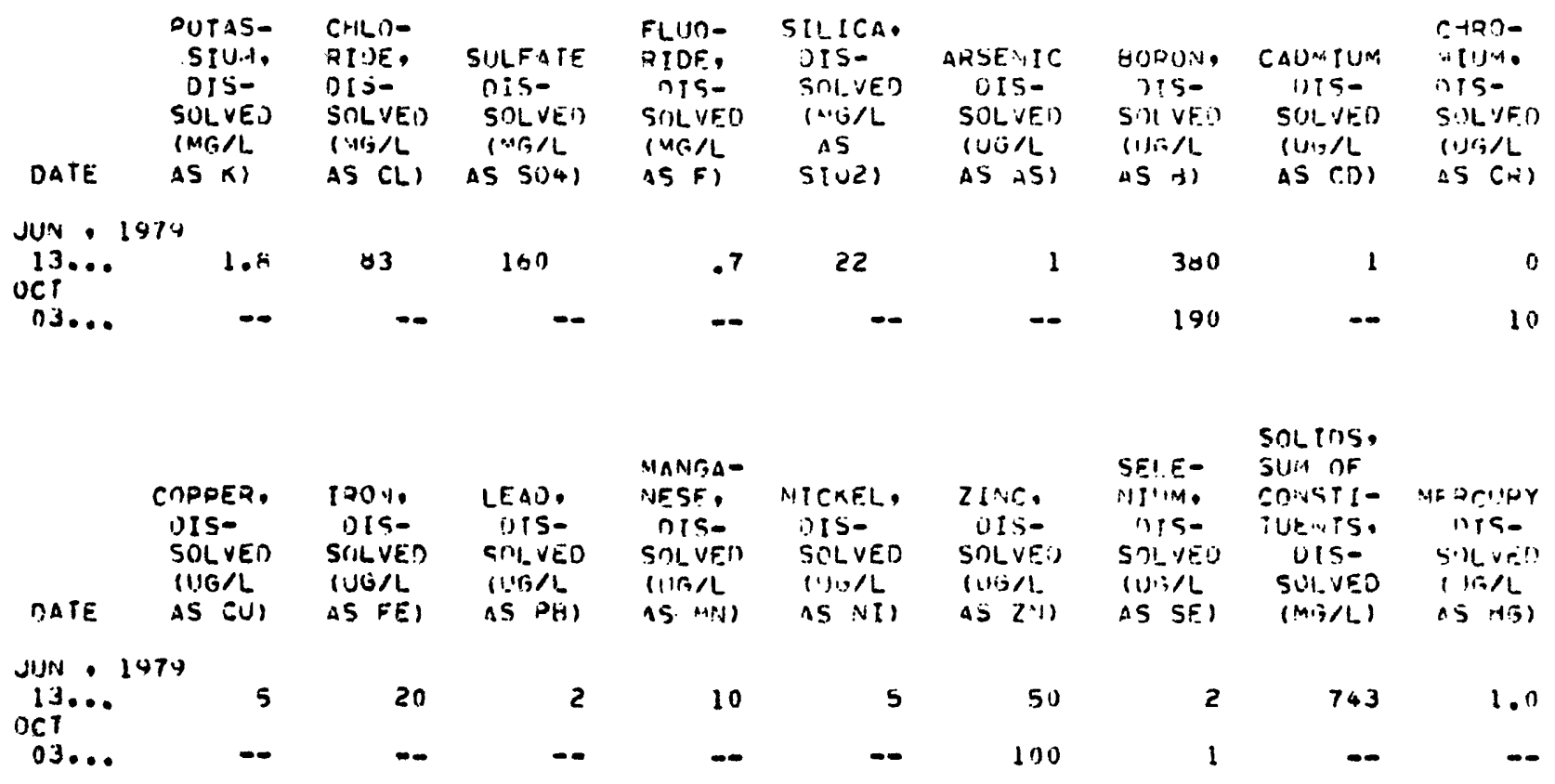


WATER-QUAEITY DATA FOR EVAPORATION POND, KAYDEN POWERPLANT, HAYDEN, COLO.

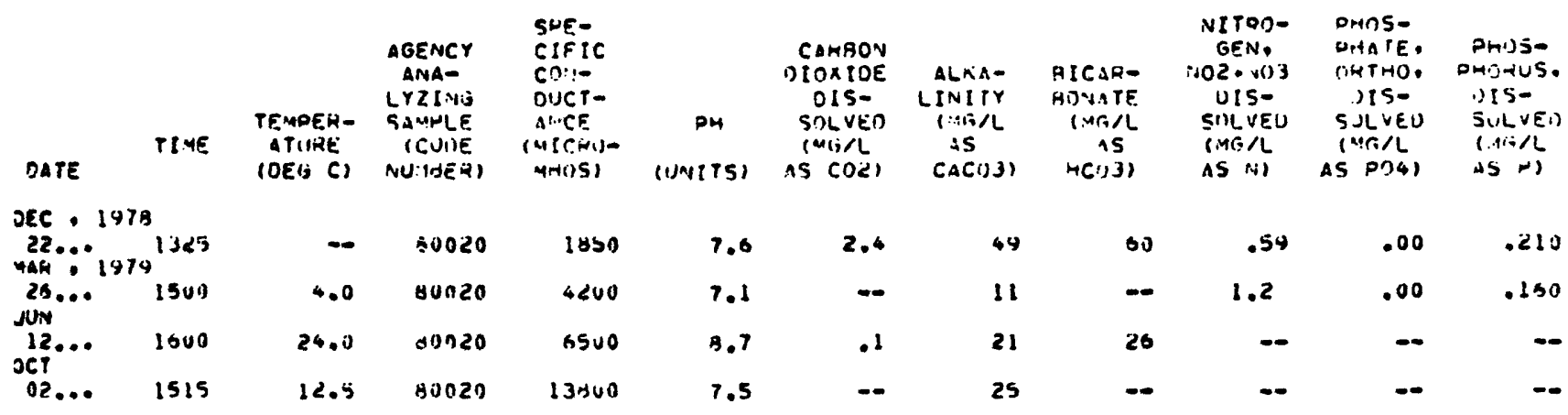

\begin{tabular}{|c|c|c|c|c|c|c|c|c|c|c|}
\hline UATE & $\begin{array}{l}\text { PHOS- } \\
\text { PHONIIS, } \\
\text { OQTHI) } \\
\text { OIS- } \\
\text { SOLVEO } \\
\text { I:ALAL } \\
\text { AS PI }\end{array}$ & $\begin{array}{l}\text { HARI)- } \\
\text { VESS } \\
\text { (MSAL } \\
\text { AS } \\
\text { CACO3) }\end{array}$ & 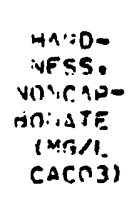 & $\begin{array}{l}\text { CALCIIJA } \\
\text { OPSE } \\
\text { SNLVER } \\
\text { (MG/L } \\
\text { AS CA) }\end{array}$ & 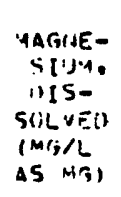 & 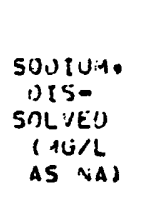 & 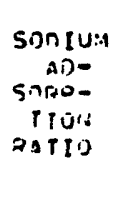 & $\begin{array}{l}\text { SOUIUM } \\
\text { PEACENT }\end{array}$ & 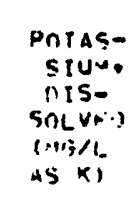 & $\begin{array}{l}\text { CMICO- } \\
\text { RII)E. } \\
\text { TIS- } \\
\text { SIUVEU } \\
\text { (V:OLL } \\
\text { AS CL) }\end{array}$ \\
\hline $\begin{array}{l}D E C \bullet \\
2 C . \cdots \\
\text { MAR }\end{array}$ & is & 690 & $64 n$ & 180 & 58 & 120 & 2.11 & 27 & 14 & 43 \\
\hline & .00 & 14010 & 1400 & 240 & 140 & 450 & 5.3 & 41 & 42 & 310 \\
\hline & - & $-\infty$ & - & - & $\infty$ & -- & $\infty$ & $-\infty$ & -- & -- \\
\hline $02 \ldots$. & - & $-\infty$ & -- & $-\infty$ & - & $-\infty$ & $\infty$ & - & -- & - \\
\hline DATE & $\begin{array}{l}\text { SULFATE } \\
\text { OIS- } \\
\text { SNLVF,U } \\
(4 G / L \\
\text { AS Sil4) }\end{array}$ & 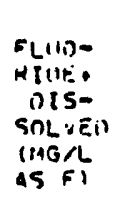 & 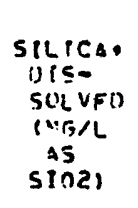 & $\begin{array}{c}\text { APSFNATC } \\
\text { nis- } \\
\text { SULVFn } \\
\text { (IIOA } \\
\text { AS ASI }\end{array}$ & 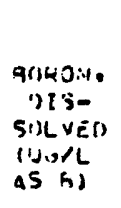 & 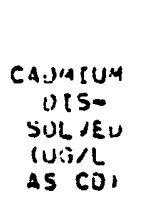 & 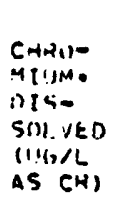 & $\begin{array}{l}\text { CNUjER, } \\
\text { nIS- } \\
\text { SIL VEI) } \\
\text { (1)ij/L } \\
\text { AS CU) }\end{array}$ & 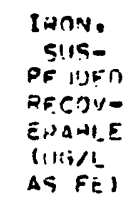 & 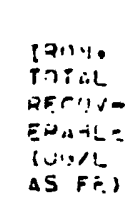 \\
\hline 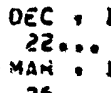 & 17870 & 1.3 & 27 & 4 & 1700 & 1 & 10 & 3 & $-\infty$ & - \\
\hline $\operatorname{Jin}_{\lim }^{25 . . .}$ & 1900 & $3 . \pi$ & 25 & - & 3900 & -- & 0 & - & $7 \div 0$ & d4u \\
\hline טद्र & $-\infty$ & $-\infty$ & $-\infty$ & -- & $\$ 30$ & -- & $-\infty$ & -- & -- & $-\infty$ \\
\hline $02 \ldots$ & 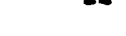 & $\cdots$ & $-\infty$ & - & 13000 & $\cdots$ & 20 & -- & -- & - \\
\hline DATE & $\begin{array}{l}\text { IDON } \\
\text { Als- } \\
\text { SinLVEU) } \\
(116 / L \\
\text { AS Ft.) }\end{array}$ & $\begin{array}{l}\text { LEAn. } \\
\text { BIS- } \\
\text { SnLVE.1) } \\
(111 \text { is/. } \\
\text { AS POSI }\end{array}$ & 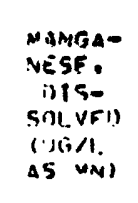 & 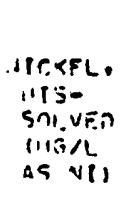 & 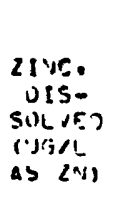 & 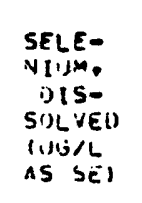 & 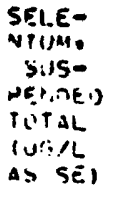 & $\begin{array}{l}\text { SELE- } \\
\text { IUUUA, } \\
\text { POITAL } \\
\text { (IUU/L } \\
\text { AS SE) }\end{array}$ & 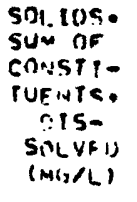 & 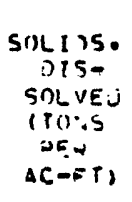 \\
\hline $\begin{array}{l}\text { UEC } 11 \\
22 . . .1 \\
\text { MAN } \because 1\end{array}$ & 0 & 2 & 210 & 5 & 39 & $\downarrow$ & $\infty$ & -- & 1300 & 1.71 \\
\hline ".... & 30 & -- & inno & -- & 511 & 14 & - & -- & 31411 & 4.32 \\
\hline $\begin{array}{c}12 \ldots . . \\
\text { oc } \\
\text { de... }\end{array}$ & 40 & - & 4.1 & $\cdots$ & -- & $\rightarrow$ & - & -- & $-\infty$ & $-\quad-\infty$ \\
\hline & 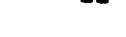 & 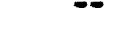 & - & $\cdots$ & คn & 3 & $v$ & 3 & $\cdots$ & $\cdots$ \\
\hline
\end{tabular}


WATER-QOACITY DATA FOR INTERMEDTATE-QOALITY POND, RAYDEN POWERPLANT, HAYDEN, COLO.

\begin{tabular}{|c|c|c|c|c|c|c|c|c|c|c|c|}
\hline DATE & TIME & $\begin{array}{l}\text { TEMPER- } \\
\text { ATIME } \\
\text { (NEG C) }\end{array}$ & $\begin{array}{l}\text { AGENCY } \\
\text { ANAD } \\
\text { LYZTVE } \\
\text { SAY:PLE } \\
\text { (C'JOE } \\
\text { AUYAEWI }\end{array}$ & $\begin{array}{l}\text { SPE- } \\
\text { CIFIC } \\
\text { CI)N- } \\
\text { NUCT- } \\
\text { AUCE } \\
\text { (MICNU- } \\
\text { MHIIS) }\end{array}$ & $\begin{array}{c}\text { PH } \\
\text { (UNITS) }\end{array}$ & $\begin{array}{l}\text { CAABON } \\
\text { OIOXIUE } \\
\text { DIS- } \\
\text { SOLVEO } \\
\text { (YG/L } \\
\text { AS COLL }\end{array}$ & $\begin{array}{l}\text { ALKA- } \\
\text { LIVITY } \\
\text { PNG/L } \\
\text { AS } \\
\text { CACOS) }\end{array}$ & $\begin{array}{c}\text { HICUA- } \\
\text { RINATE } \\
\text { (MI:AL } \\
\text { AS } \\
\text { men3) }\end{array}$ & $\begin{array}{l}\text { CADD } \\
\text { OONATE } \\
\text { (MG/L } \\
\text { AS Cn3) }\end{array}$ & 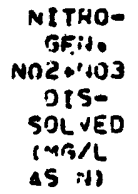 & 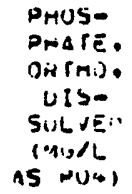 \\
\hline
\end{tabular}
DEC + 1978

\begin{tabular}{|c|c|c|c|c|c|c|c|c|c|c|c|}
\hline & 1335 & $\infty$ & 00020 & 3200 & 0.1 & 1.0 & 90 & 110 & 0 & .07 & $-\infty$ \\
\hline $26 \ldots$ & 1530 & 5.5 & $5190<0$ & 2500 & 9.1 & $\infty$ & 6s & $-\infty$ & - & .82 & 1.4 \\
\hline $12 \cdot 0$ & 150.3 & 20.0 & \$0.120 & 3250 & 9.4 & .0 & 68 & 33 & $-\infty$ & $\infty$ & \\
\hline $03 \ldots$ & 1405 & 10.0 & 90020 & 35.00 & 9.3 & $-\infty$ & 640 & $\infty$ & $-\infty$ & $-\infty$ & - \\
\hline & $\begin{array}{l}\text { PMOS- } \\
\text { PHONIJS, } \\
\text { OIS- } \\
\text { SOLVFD } \\
\text { IMG/L }\end{array}$ & 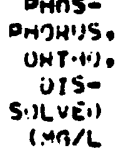 & $\begin{array}{l}\text { MANI)- } \\
\text { NESS } \\
\text { (YIS/L } \\
\text { AS }\end{array}$ & $\begin{array}{l}\text { HAHDO } \\
\text { YESS } \\
\text { NOVCANO } \\
\text { gOivATE } \\
\text { INri/L }\end{array}$ & $\begin{array}{l}\text { CAI.CIUA } \\
\text { Dis- } \\
\text { SPLVEn } \\
\text { I4C/L }\end{array}$ & $\begin{array}{l}\text { MAGNE- } \\
\text { SIU:A. } \\
\text { TIS- } \\
\text { SOLVEO } \\
\text { I UIOLL }\end{array}$ & $\begin{array}{l}\text { SOUI:IM, } \\
\text { DISE } \\
\text { SOLVED } \\
\text { IME/L }\end{array}$ & 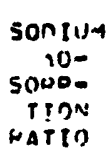 & & $\begin{array}{l}\text { DOTAS- } \\
\text { SIUM. } \\
\text { DIS- } \\
\text { SOLVED } \\
\text { PME/L }\end{array}$ & 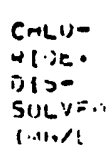 \\
\hline Dal & as Pा & AS P) & $(\operatorname{sic} 3)$ & CACUSI & AS (A) & AS M(S) & AS tAl & & ENT & $45 \times 1$ & is (L) \\
\hline
\end{tabular}

OEC - 1979

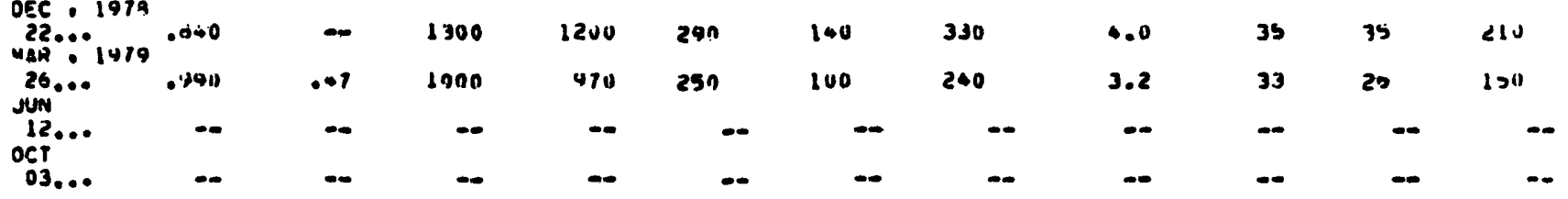

\begin{tabular}{|c|c|c|c|c|c|c|c|c|c|c|}
\hline & $\begin{array}{l}\text { SULFATE } \\
\text { UIS- } \\
\text { SOLVES } \\
\text { SMFS }\end{array}$ & 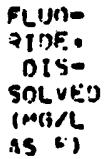 & 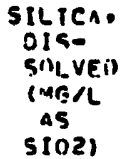 & $\begin{array}{c}\text { ARSEYIC } \\
\text { nIS- } \\
\text { SnLYEn } \\
\text { (115/L } \\
\text { AS ASI }\end{array}$ & $\begin{array}{l}\text { bUWRA. } \\
\text { IIS- } \\
\text { SULVER } \\
\text { (WERL } \\
\text { AS A) }\end{array}$ & $\begin{array}{c}\text { CA:IAIUM } \\
\text { UIS- } \\
\text { SOLVEU) } \\
\text { (IJIS/L } \\
\text { AS COI }\end{array}$ & 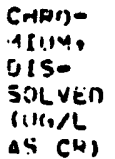 & $\begin{array}{l}\text { CODLER, } \\
\text { IISE } \\
\text { SULVFO } \\
\text { (UIJ/L } \\
\text { AS CUS }\end{array}$ & 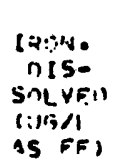 & 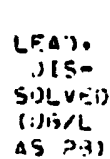 \\
\hline & & & & & & & & & & \\
\hline
\end{tabular}

DEC. $141 \mathrm{H}$

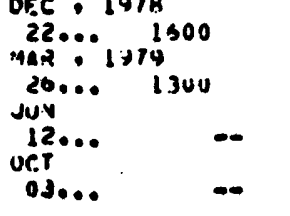

$\begin{array}{cr}2.2 & 26 \\ 2.0 & 37 \\ \cdots & -\end{array}$

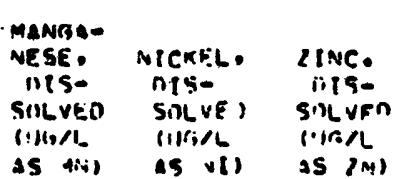

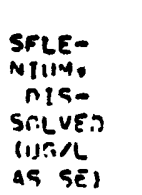

S\& LeNivis. Suspriyne? TAPAL (IIi)l. AS SE,

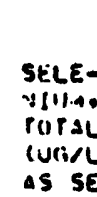

solins.

sin of soltus.

Cinsti- WIS- MERCINA

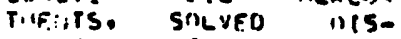

its- iflens sulve:) sample

BIILVEO HEK Rij/

$(: A F / L) \quad A C-f(T) \quad$ AS H(i)

SOIYOCE
DFC - 147A

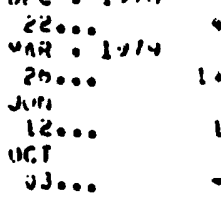

$\begin{array}{ccc}00 & 0 & 70 \\ 100 & \ldots & 40 \\ 10 & \ldots & \ldots \\ \ldots & \ldots & 41\end{array}$

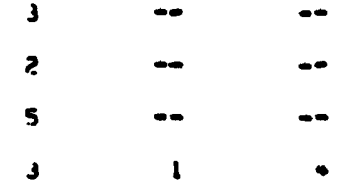

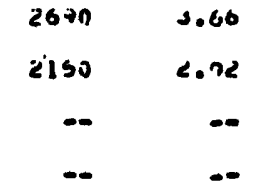


MMERmgOALITY DATA FOR OTI-SKIMMER POND, HAYDEN POWERPLANT, HAYDEN, COLO.

\begin{tabular}{|c|c|c|c|c|c|c|c|c|c|c|c|}
\hline Date & TINE & $\begin{array}{l}\text { TFMPER- } \\
\text { ATUHE } \\
\text { (UEG C) }\end{array}$ & $\begin{array}{l}\text { AGENCY } \\
\text { AMAO } \\
\text { LYZI UG } \\
\text { SAPALLF. } \\
\text { (COOE } \\
\text { NUMHEN) }\end{array}$ & $\begin{array}{l}\text { SPE- } \\
\text { CIFIC } \\
\text { CUNE } \\
\text { nUCT- } \\
\text { AICE } \\
\text { (AICLU- } \\
\text { MAOSI }\end{array}$ & $\begin{array}{c}P H \\
\left.(1) N_{4} I T S\right)\end{array}$ & $\begin{array}{c}\text { CARAON } \\
\text { OTOXIUE } \\
\text { OIS- } \\
\text { SOLVEO } \\
\text { PME/L } \\
\text { AS LUZI }\end{array}$ & $\begin{array}{l}\text { ALKA- } \\
\text { LINITY } \\
\text { IMG/L } \\
\text { AS } \\
\text { CACUJI) }\end{array}$ & $\begin{array}{c}\text { BIC:M- } \\
\text { HOMNITE } \\
\text { (MFI/L } \\
\text { AS } \\
\text { MCI) 3) }\end{array}$ & $\begin{array}{l}\text { CAP- } \\
\text { TONITE } \\
\text { (MTS } \\
\text { AS COJ) }\end{array}$ & $\begin{array}{l}\text { WITRU- } \\
\text { GEN } \\
\text { NOENUJ } \\
\text { DIS- } \\
\text { SUEVEO } \\
\text { (1S/L } \\
\text { AS VI) }\end{array}$ & $\begin{array}{l}\text { UMOS- } \\
\text { PMAIE. } \\
\text { OATAI. } \\
\text { OIS- } \\
\text { SULVEN } \\
\text { IM(jAI. } \\
\text { AS POA) }\end{array}$ \\
\hline \multirow{4}{*}{ 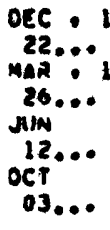 } & 1350 & - & 80020 & 1500 & 7.6 & 4.3 & 55 & 67 & 0 & .82 & $=$ \\
\hline & $15+5$ & 24.0 & 30020 & 2050 & 1.2 & - & 30 & $-\infty$ & - & 3.1 & .un \\
\hline & 1505 & 11.0 & 80020 & 975 & 9.5 & .0 & 38 & 46 & - & $\cdots$ & $\cdots$ \\
\hline & 1355 & 17.0 & s0nzo & 1700 & 3.0 & $\cdots$ & 1 & - & $-\infty$ & - & - \\
\hline DATE & $\begin{array}{l}\text { PMOS- } \\
\text { PHnAUS. } \\
\text { OIS- } \\
\text { SOL VE!! } \\
\text { (MGSL } \\
\text { AS NI) }\end{array}$ & $\begin{array}{l}\text { DHOS- } \\
\text { PHURUS. } \\
\text { OHTHU. } \\
\text { UIS- } \\
\text { SUVE) } \\
\text { (MG/L } \\
\text { AS P) }\end{array}$ & $\begin{array}{l}\text { Madn- } \\
\text { iJESS } \\
\text { (WHOLL } \\
\text { AS } \\
\text { CACU3) }\end{array}$ & 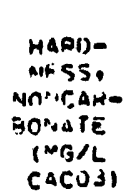 & $\begin{array}{l}\text { CALCliJM } \\
\text { OISE } \\
\text { SOLVFO } \\
\text { (MGEL } \\
\text { AS CA) }\end{array}$ & 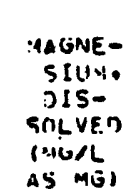 & 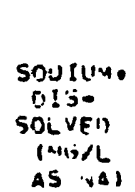 & $\begin{array}{c}\text { Soniua } \\
\text { An- } \\
\text { Shas- } \\
\text { Trond } \\
\text { WaTlo }\end{array}$ & $\begin{array}{l}\text { SOUTUM } \\
\text { NEWCE IT }\end{array}$ & 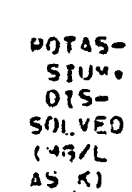 & 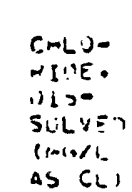 \\
\hline
\end{tabular}

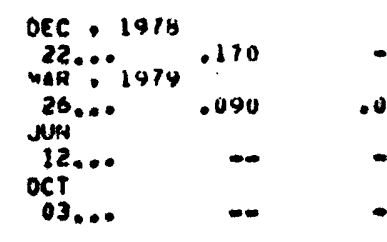

\begin{tabular}{|c|c|c|c|c|c|c|}
\hline & $\begin{array}{l}\text { SULFATE } \\
\text { DIS- } \\
\text { SOLVED } \\
\text { IAG/L }\end{array}$ & $\begin{array}{l}\text { FLUO- } \\
\text { PIDE. } \\
\text { OIS- } \\
\text { SOLVEO } \\
\text { IMG/L }\end{array}$ & $\begin{array}{c}\text { SILTCA. } \\
\text { 1)IS- } \\
\text { SOI.VEI! } \\
\text { P4r.lL } \\
45\end{array}$ & $\begin{array}{c}\text { ANSFFNIC } \\
\text { nIE- } \\
\text { SnLVEn } \\
\text { IIII/L }\end{array}$ & $\begin{array}{l}\text { Ananel, } \\
\text { ors- } \\
\text { Si)lven } \\
\text { (usit }\end{array}$ & 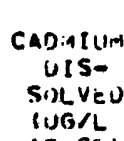 \\
\hline DATE & as somi & $\Delta 5 F$ & $5(02)$ & AS ASI & AS $H$ ) & AS CUI \\
\hline
\end{tabular}

CHAO-

Allim

11 ! -

SDI.VEI)

( JTIL

AS $\mathrm{CH}$ )
1.7
2.5
--
-

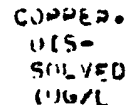

as (i)

$\begin{array}{lll}25 & 13 & 05 \\ 30 & 13 & 01 \\ -- & -\infty & \ldots\end{array}$

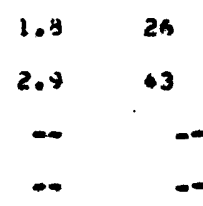

1400
2100
1500

$<1$
--
--

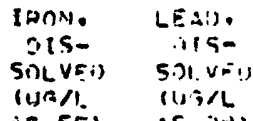

is F(F) as int
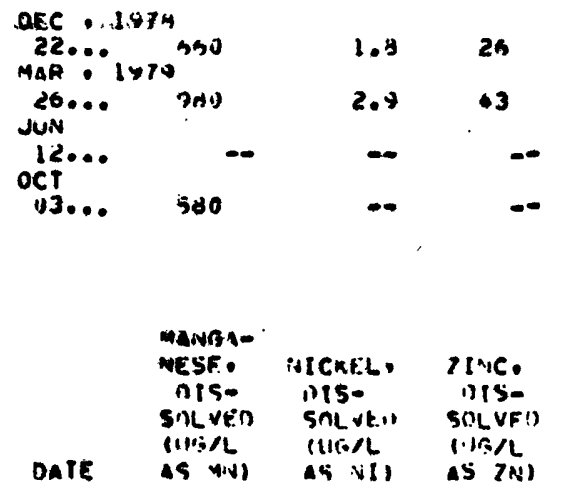

$$
\begin{aligned}
& \text { SELF- } \\
& \text { NiIIU. } \\
& \text { NIS- } \\
& \text { SOLVEN } \\
& \text { IIIGIL }
\end{aligned}
$$

SELE-

Nivin.

of.vi)fo

i Jij/L

AS SEI

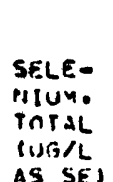

AS SE)
SOLIOS. Sum no

(i) UST 1PIE:TS. nis-

S.U. $(v t$.

(NG/L)
SilLLiSS.

UIS- NEUCHIS

SUI.VEI) TIS-

(1)jis SIlLVEN SATDLE

DF.H (1\%:/I. SOHFCE

$A C-F$ TI AS M(S)

OEC - 14/4

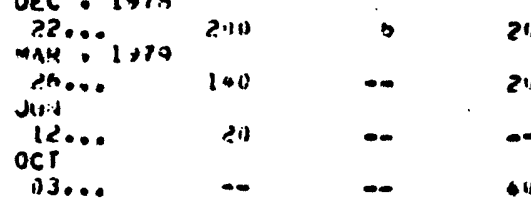

211

$$
\begin{array}{cc}
5 & \cdots \\
i 1 & \cdots \\
4 & 0
\end{array}
$$$$
\begin{array}{rr}
-0 & 1120 \\
- & 1530 \\
- & - \\
- & \ldots
\end{array}
$$

1.52
2.22
$\ldots$
$\ldots$

$\begin{array}{ll}\therefore 1 & 40 \\ - & -- \\ \ldots & -- \\ \ldots & \ldots\end{array}$


WATER-QOALITY DATA FOR EIGH-QUALITX POND, HAYDEN POWERPLANT, HAYDEN, COLO.

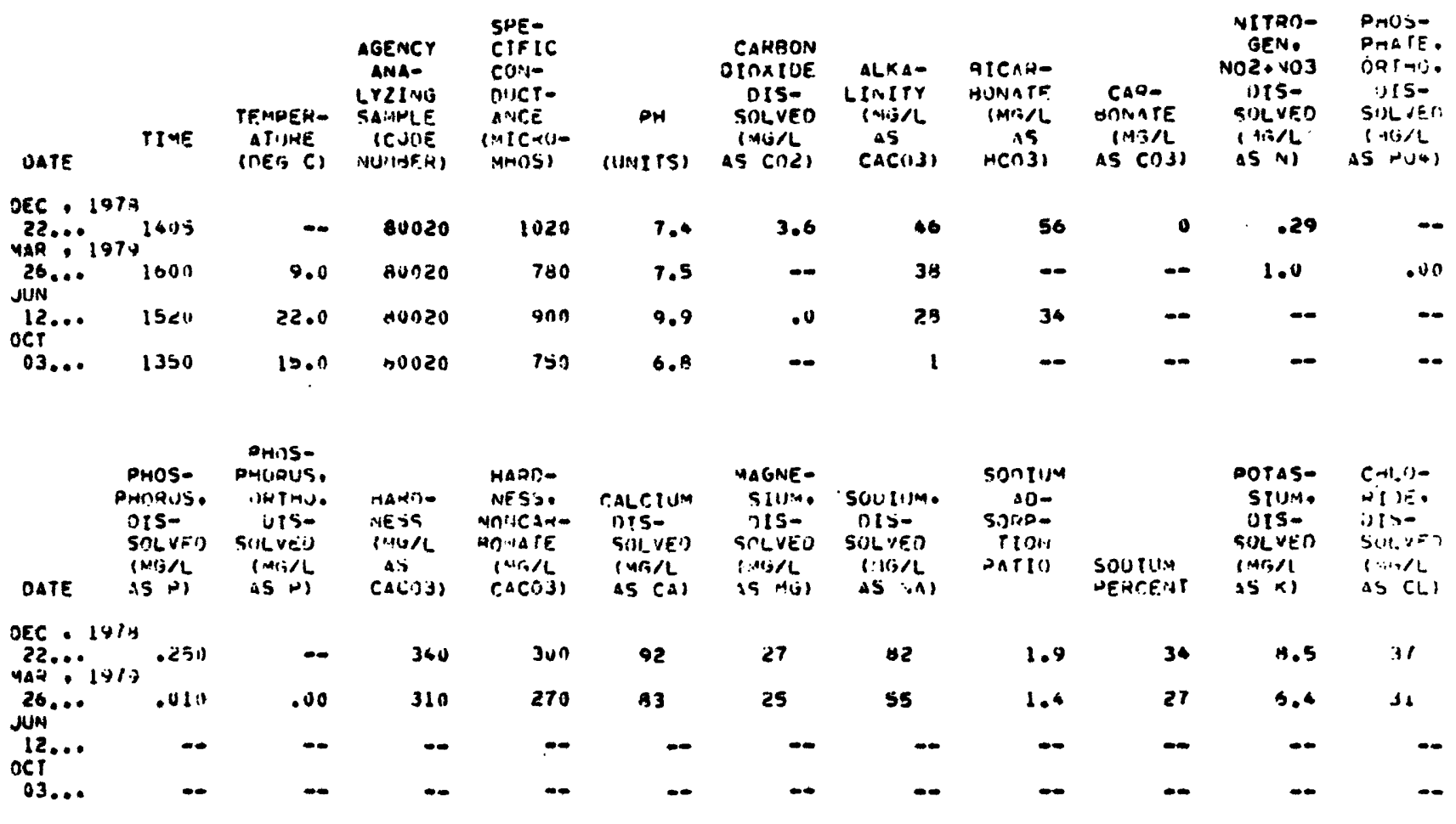

DATE AS

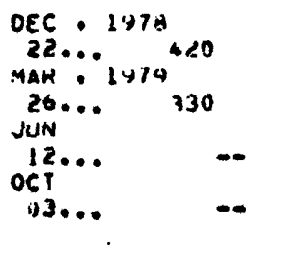

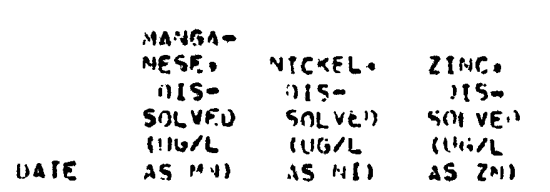

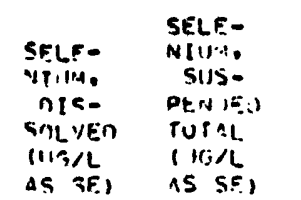

CHPO-

vive

0 is-

SILVED

(Ui:L

.45.(त)

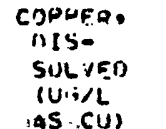

เนกข

1)I $5-$

Siluveu

(1) $1 / 1$.

LF : is

SOLVE.

(u)

AS P 1

DEC I IYIA

\begin{tabular}{|c|c|c|}
\hline $\begin{array}{l}220 \cdots 1+10 \\
M A H \cdots 1 Y 10\end{array}$ & 130 & 6 \\
\hline PO०... & 40 & $-\infty$ \\
\hline 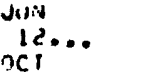 & !1) & $-\infty$ \\
\hline (1) & $-\infty$ & $-\infty$ \\
\hline
\end{tabular}

\section{0 \\ 1s.10 \\ 1500}

$-$

$$
-
$$

$+\infty$

$$
\text { - }
$$
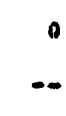

10

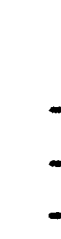

8
$-\infty$
$-\infty$

solins.

Sul of solidus.

CDAStI- UTS- hencyot

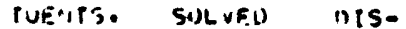

DIS- PUMPS SOLVER SAnPLE

SIILVE:

$(N G / L)$ oty

$A C \sim(1)$
(UTSLL,

SOI:ACE

AS SE)
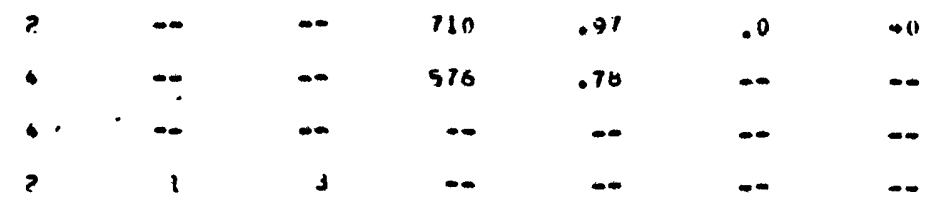
WATER-QUALITY DATA FOR RAN WATER STORAGE POND NO. 1, HAYDEN POWERPLANT, HAYDEN, COLO.

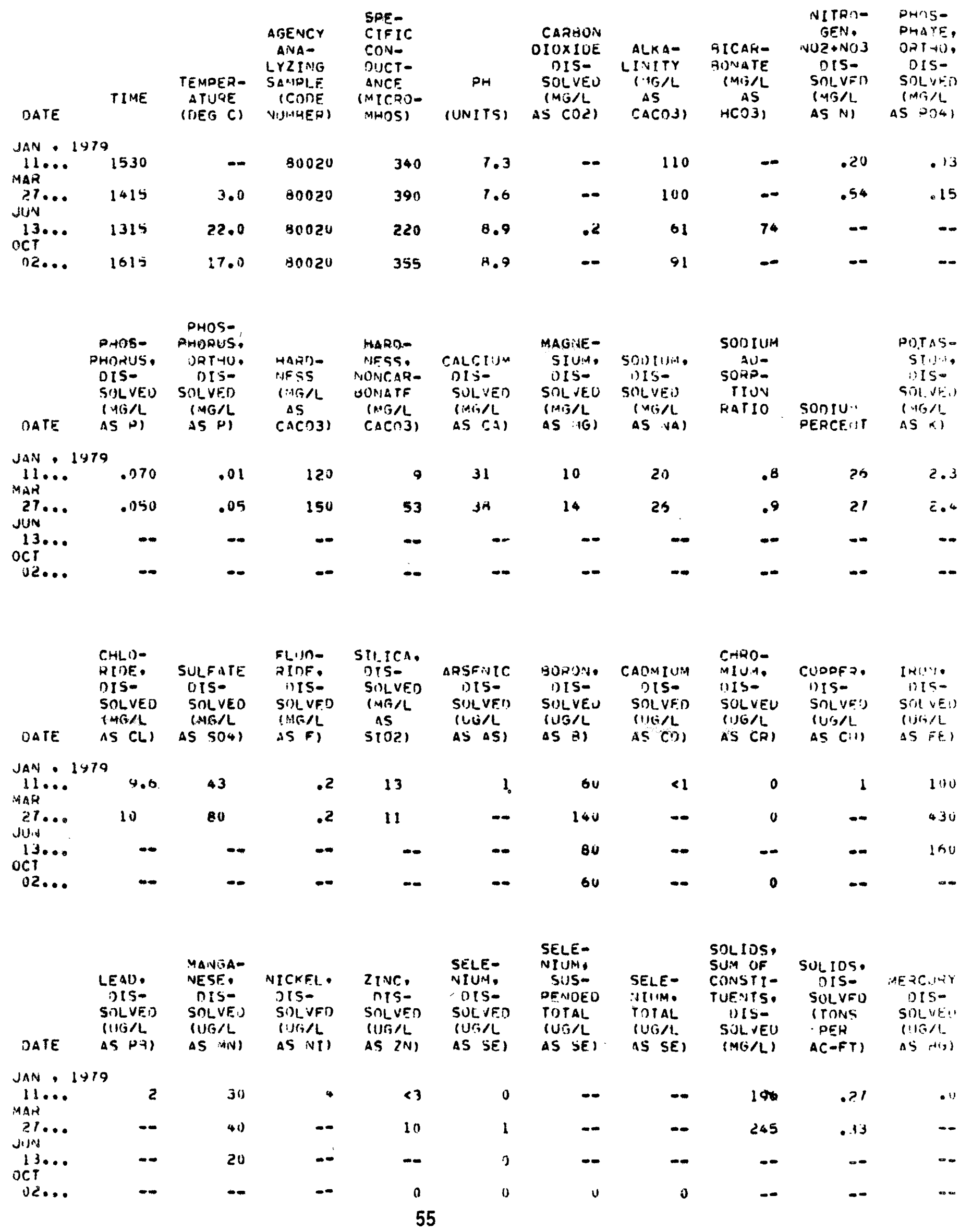


WATER-QOAREITY DATA FOR WELE HS-1, HAYDEN PONERPLANT, HAYDEN, COLO,

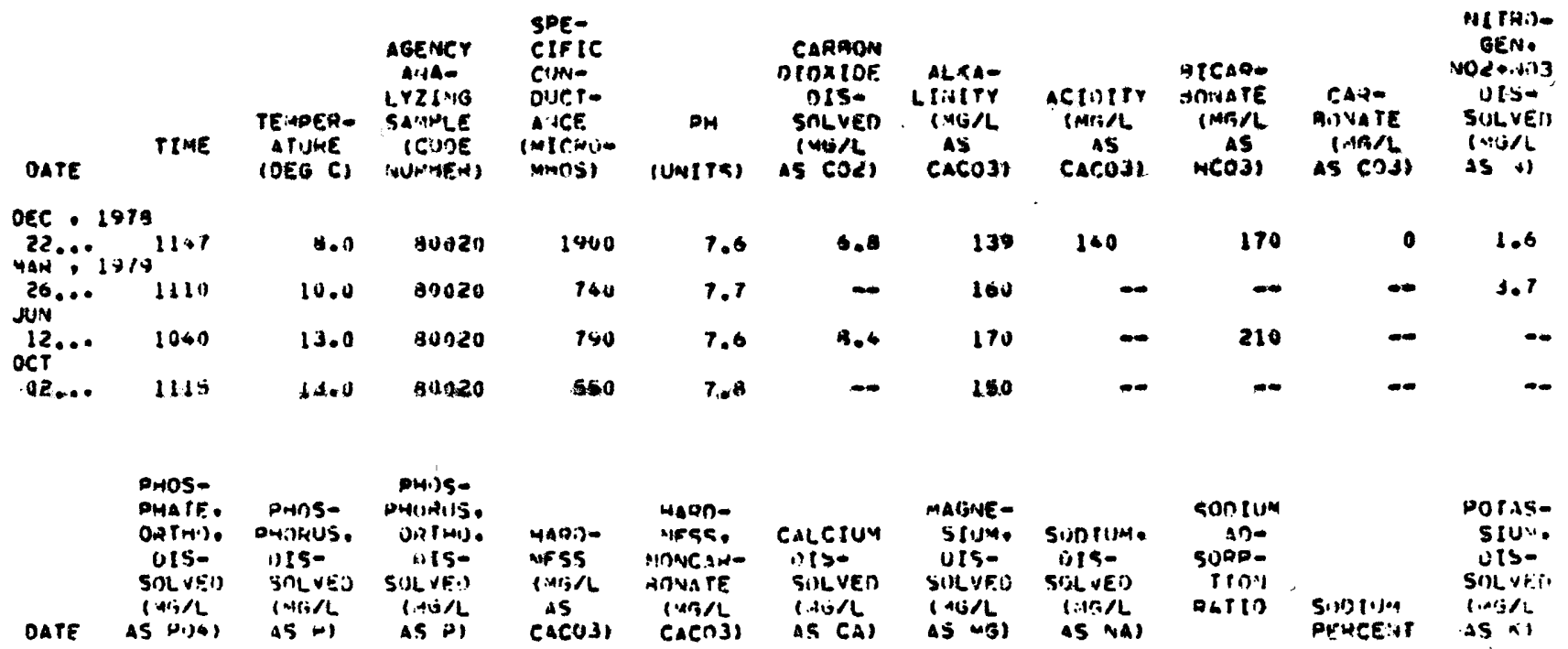

\begin{tabular}{|c|c|c|c|c|c|c|c|c|c|c|c|}
\hline DEC 21973 & $\ldots$ & . uso & $\cdots$ & 850 & 110 & 140 & 90 & 150 & 2.2 & 28 & 3.4 \\
\hline $26 . .$. & .179 & .050 & .03 & 230 & 09 & 52 & 24 & 70 & 2.0 & 40 & 3.7 \\
\hline $12 . .$. & $\cdots$ & - & - & $\infty$ & - & - & -- & - & - & $\infty$ & - \\
\hline 1 & - & 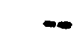 & $\omega$ & - & - & - & -. & $\cdots$ & - & -. & .- \\
\hline
\end{tabular}

\begin{tabular}{|c|c|c|c|c|c|c|c|c|c|c|}
\hline & $\begin{array}{l}\text { CHLO- } \\
\text { OTDE. } \\
\text { OIS- } \\
\text { SILVEU } \\
\text { 1'45/6 }\end{array}$ & $\begin{array}{l}\text { SULFate } \\
\text { DISA } \\
\text { SnLVE") } \\
\text { (WH'Ll }\end{array}$ & 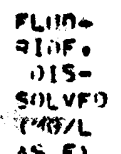 & $\begin{array}{l}\text { SILICE. } \\
\text { "ISS- } \\
\text { SnLVED } \\
\text { I YG/ } \\
\text { As }\end{array}$ & 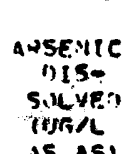 & $\begin{array}{l}\text { HOWDA, } \\
\text { UIS- } \\
\text { SOLVEU } \\
\text { WOT/L }\end{array}$ & 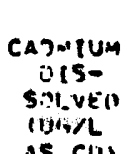 & 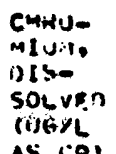 & $\begin{array}{l}\text { coones, } \\
\text { urse } \\
\text { SnLyei) } \\
\text { (ifrelt }\end{array}$ & 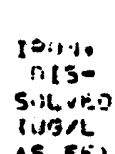 \\
\hline & As $(L)$ & as 5041 & AS Fi & $5(n 2)$ & 25 (5) & AS 31 & & & & \\
\hline
\end{tabular}

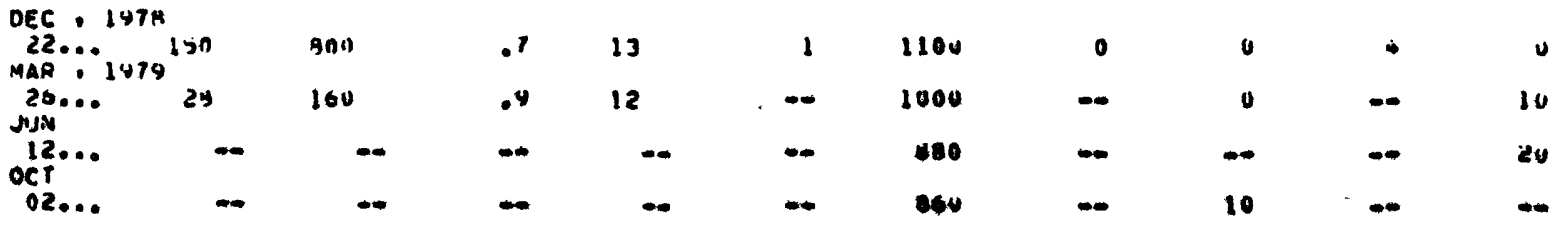

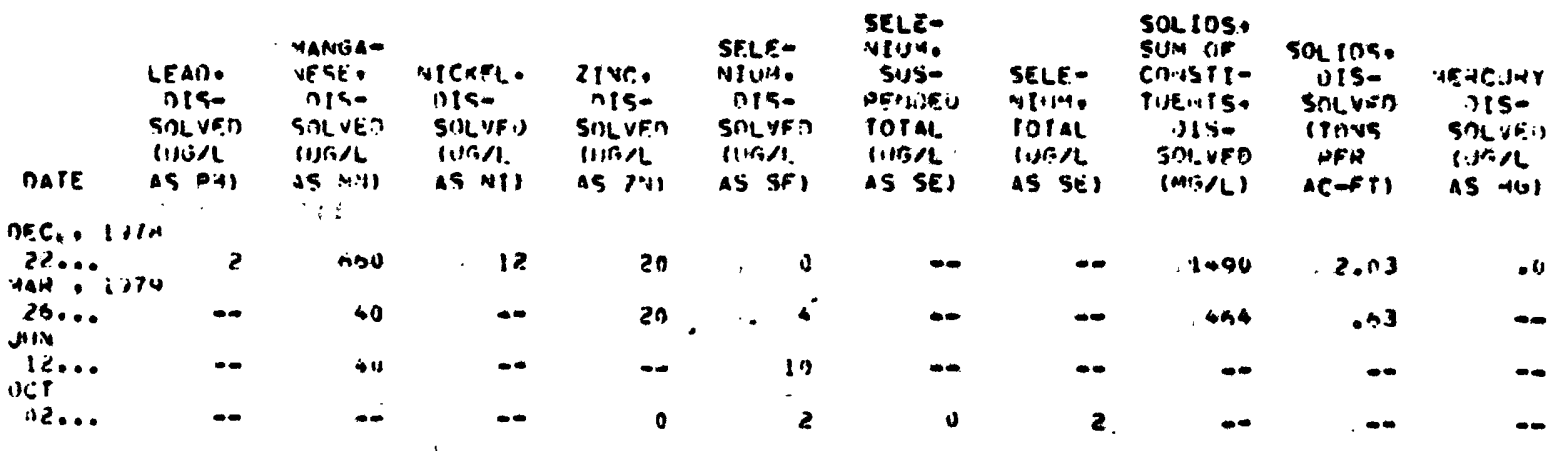


WATER-QOALITY DATA FOR WELL RS-2, HAYDEA POWERPLANT, HAYDEN, COLO.

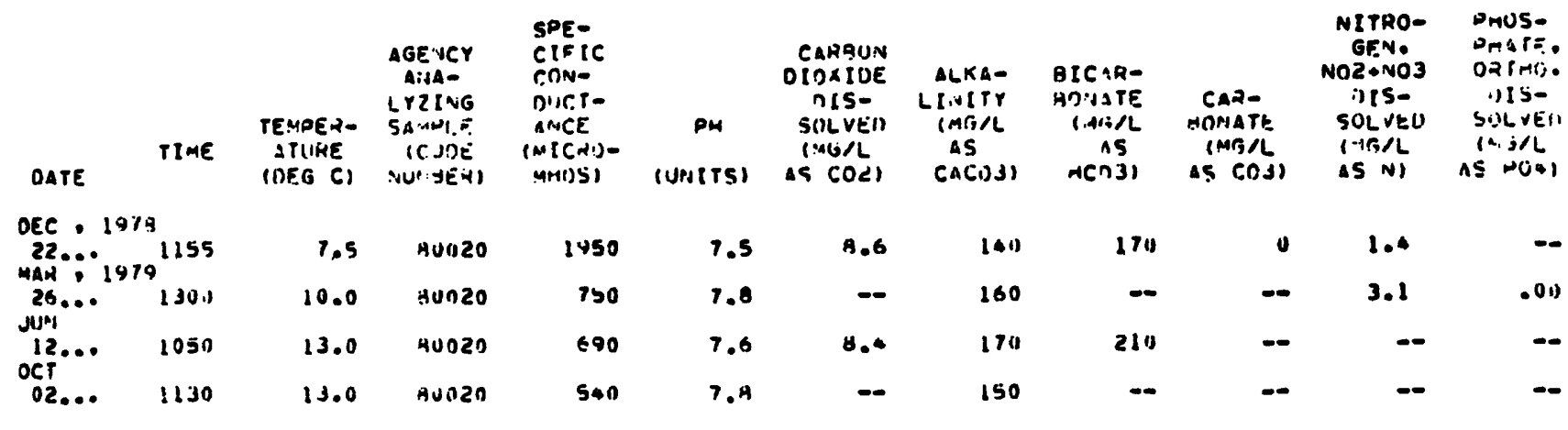

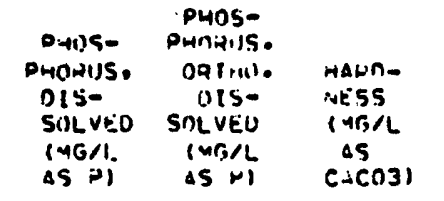

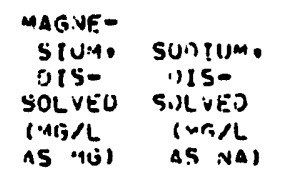

AS NA)

SOIIIUid
WI!-
SiJMW-
TIOAi.
WAPIO

a.s Cis

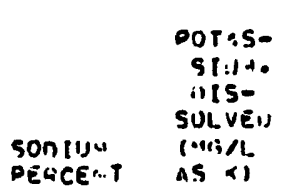

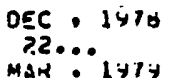

\section{.050}

- 870

$73 n$

201)

99

150

26 ...

.0 .10

$.0 n$

210

5)

43

2s

87

2.2

PEACEN.. T

A. $\times 1$

Jifing.

a2...

\begin{tabular}{|c|c|c|c|c|c|c|c|}
\hline & $\begin{array}{l}\text { CHLD- } \\
\text { AIUE. } \\
\text { OIS- } \\
\text { SNLVEU } \\
\text { I:1G/L }\end{array}$ & $\begin{array}{l}\text { SII.FAIE } \\
\text { UIS- } \\
\text { SALVE!) } \\
\text { (MG/L }\end{array}$ & 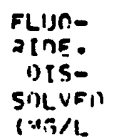 & $\begin{array}{l}\text { SIt.TEA. } \\
\text { nis- } \\
\text { SnLVEn } \\
\text { I MG/I. } \\
\text { IS }\end{array}$ & $\begin{array}{c}\text { AQSEYIC } \\
\text { OISE } \\
\text { SH, VF! } \\
\text { IUS/L }\end{array}$ & $\begin{array}{l}\text { AOZINN. } \\
\text { OISO } \\
\text { SOLVED } \\
\text { WUILL }\end{array}$ & $\begin{array}{c}\text { CAINIUA } \\
\text { IIS- } \\
\text { SIIVEO } \\
\text { WUT/L }\end{array}$ \\
\hline te & AS CLI & as $50+1$ & AS Fi & SI(1)) & $\triangle 5$ aSI & $45 \mathrm{dI}$ & AS CUI \\
\hline
\end{tabular}

Cnmo-

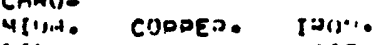

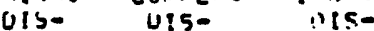

SillvFu SAlVES SIILVEU (uij/l life/l is (Q) as C.il as E! DEC - 1\%79

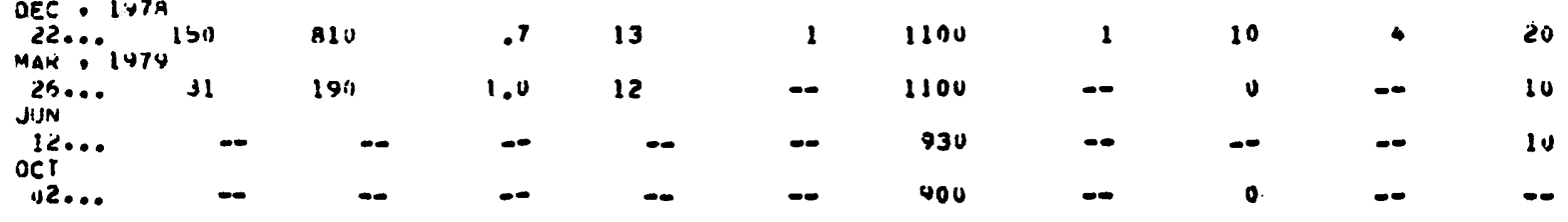
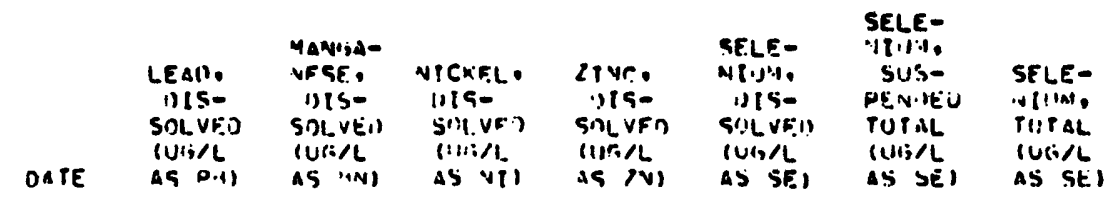

Sol ins:

Sol ins

SU:4 UF SOl ins.

elinsti- IIT- Mencliar

rije..is, sniveil ilise

DIS- (TIINA SUIVE,)

SULVD SER (UTRL

UEC. 1414

\begin{tabular}{|c|c|c|c|c|}
\hline $22 \ldots$ & 2 & 1300 & 12 & $2 n$ \\
\hline $\begin{array}{l}414,19 / 3 \\
20 . \ldots .\end{array}$ & -- & 1111 & $-\infty$ & 10 \\
\hline$J(V .2$ & & & & \\
\hline$x^{1} \div \cdots$ & $-\infty$ & (U) & - & \\
\hline $2<\ldots$ & $\infty$ & $\infty$ & $-\infty$ & \\
\hline
\end{tabular}




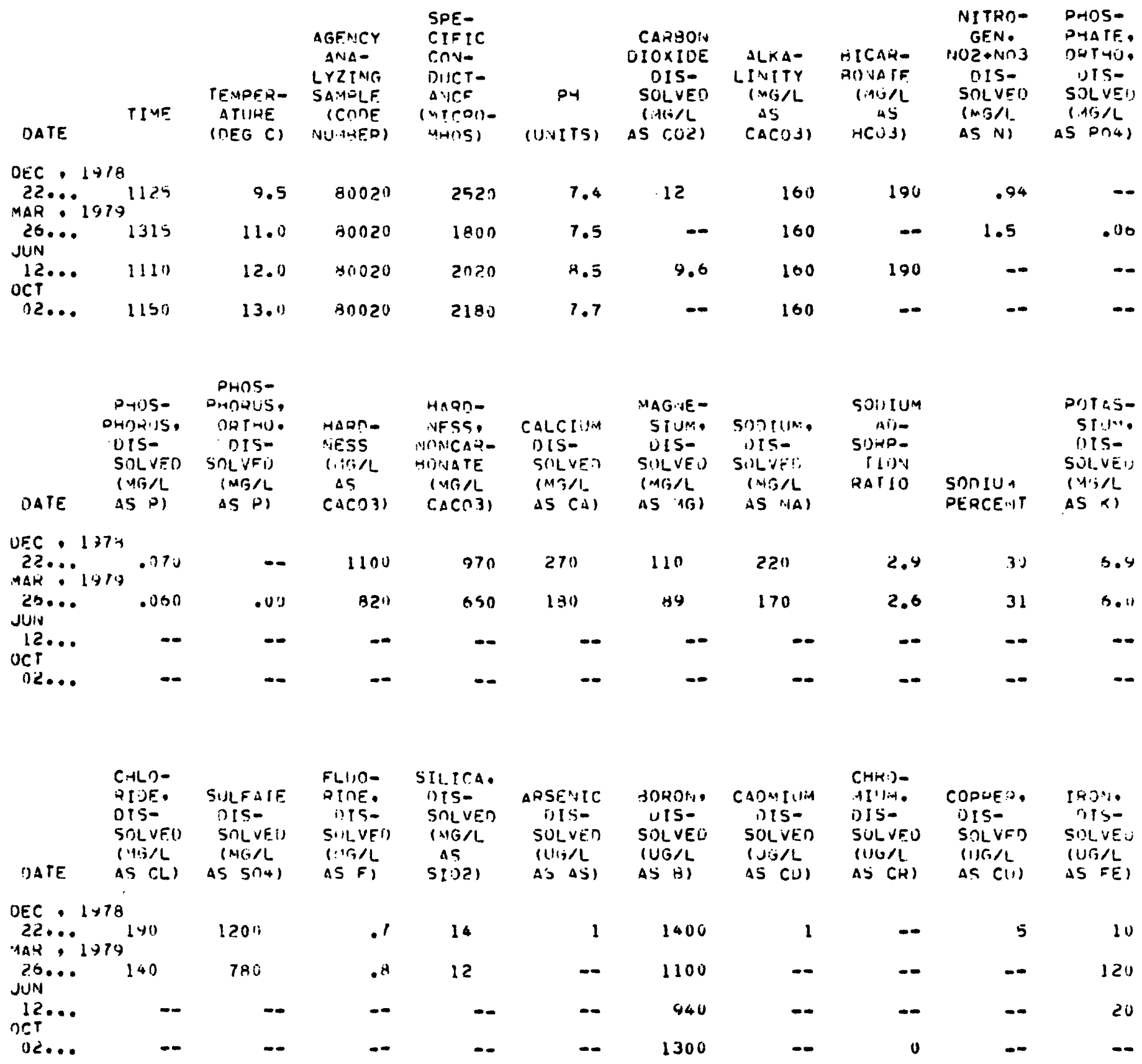

\begin{tabular}{|c|c|c|c|c|c|c|c|c|c|}
\hline DATE & $\begin{array}{l}\text { LEAD, } \\
\text { UIS- } \\
\text { SUL VED } \\
\text { (USA } \\
\text { AS } P+B)\end{array}$ & $\begin{array}{l}\text { MA VISA- } \\
\text { NESE. } \\
\text { I) IS- } \\
\text { SOI-VED } \\
\text { (IJiSL } \\
\text { AS 'IVI) }\end{array}$ & $\begin{array}{l}\text { UICKEL. } \\
\text { OIS- } \\
\text { SUI.vEn } \\
\text { (I!(i)L } \\
\text { AS II) }\end{array}$ & 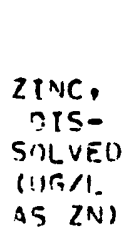 & $\begin{array}{l}\text { SELE- } \\
\text { VIUM, } \\
\text { OIS- } \\
\text { SNLVED } \\
\text { (:IU/L } \\
\text { AS SE) }\end{array}$ & $\begin{array}{l}\text { SELE- } \\
\text { NIUM, } \\
\text { SUS- } \\
\text { PE'VIE.) } \\
\text { TUTGL } \\
\text { (US,L } \\
\text { AS SEI }\end{array}$ & $\begin{array}{l}\text { SEIE- } \\
\text { UTiBA: } \\
\text { TOTAL } \\
\text { IURAL } \\
\text { GS SES }\end{array}$ & 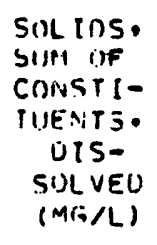 & 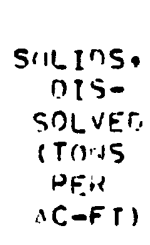 \\
\hline 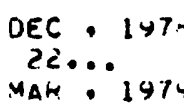 & 4 & 2100 & 11 & 40 & $-\infty$ & - & - & 2110 & 2.87 \\
\hline$\underset{J I N}{20 \ldots}$ & - & 40 & -- & 20 & 2 & -- & -- & 1440 & 2.111 \\
\hline${ }_{x \rightarrow T}^{12} \ldots$ & - & 41) & - & - & 1 & - & - & -- & - \\
\hline 112 & -- & - & - & 1,0 & 1 & 1 & 2 & -. & -- \\
\hline
\end{tabular}


WATER-QUALITY DATA FOR NELL HS-4, HAYDEN POWERPLANT, HAYDEN, COLO.

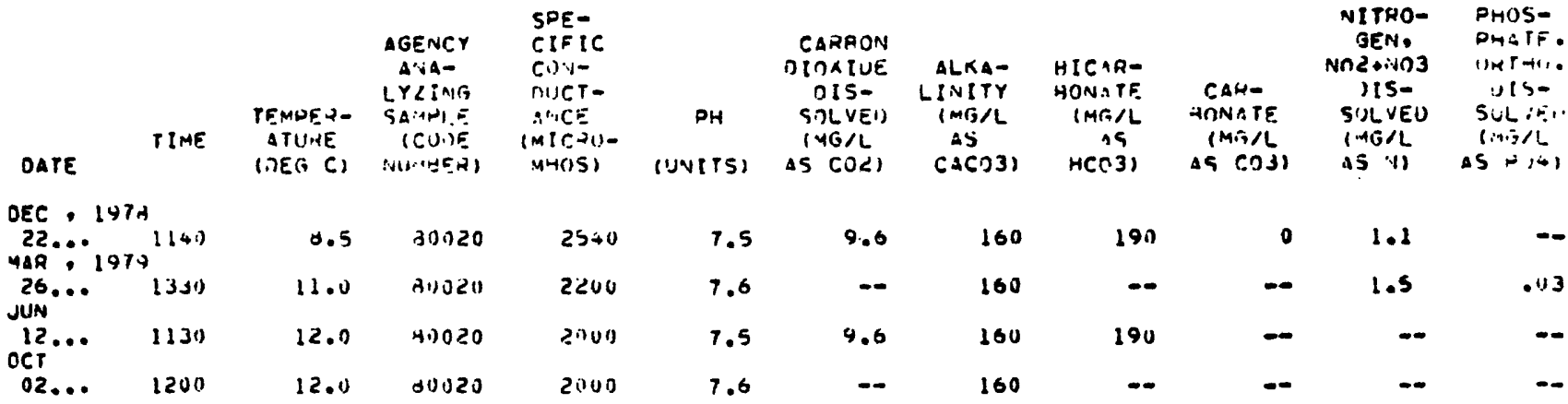

\begin{tabular}{|c|c|c|c|c|c|c|c|c|c|c|}
\hline $\begin{array}{r}P \\
P H \\
0 \\
5 \\
1 \\
1\end{array}$ & $\begin{array}{l}\text { PHDS- } \\
\text { PHIRRIIS, } \\
\text { OIS- } \\
\text { SOLVEU } \\
\text { (4G/L } \\
\text { ASPI P) }\end{array}$ & 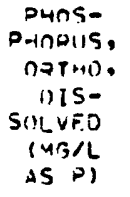 & $\begin{array}{l}4 n 2 n- \\
\text { IfSS } \\
(M 1 ; / 2 \\
19 \\
C+C O 3)\end{array}$ & 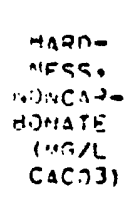 & 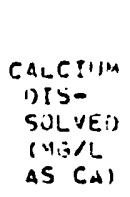 & $\begin{array}{l}\text { MAGIIE- } \\
\text { SIJAA, } \\
\text { UIS- } \\
\text { SOLVED) } \\
\text { (UR, MG } \\
\text { AS MG) }\end{array}$ & 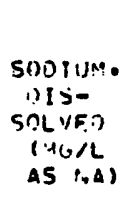 & 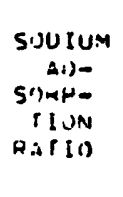 & $\begin{array}{l}\text { SOHIU.' } \\
\text { DEPCER.T }\end{array}$ & 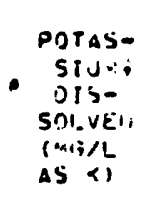 \\
\hline $\begin{array}{l}c .1973 \\
\therefore{ }_{1979}\end{array}$ & .nso & $\cdots$ & 1100 & 970 & 2713 & 110 & 230 & 3.0 & 31 & 6 \\
\hline Jun $20 . .$. & $.0+1)$ & .01 & $83 n$ & (570 & (1) & 75 & 200 & 3.0 & 34 & Q.S \\
\hline 2.... & $\cdots$ & - & $\cdots$ & -- & - & $\cdots$ & $-\infty$ & - & $\cdots$ & . \\
\hline & - & $\cdots$ & - & -- & -- & -- & - & $\cdots$ & - & \\
\hline
\end{tabular}

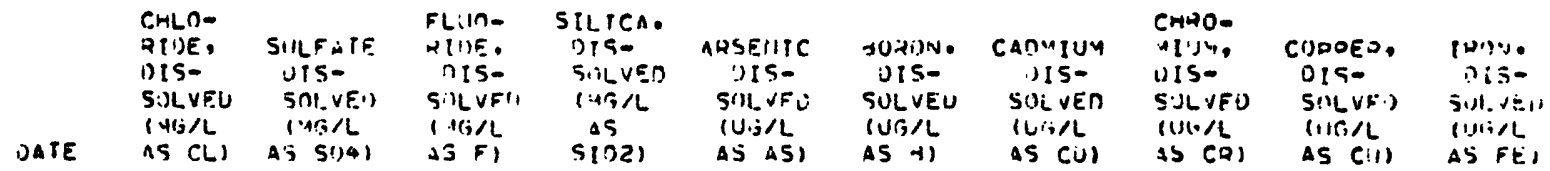

OEC, 137 H

\begin{tabular}{|c|c|c|c|c|c|c|c|c|c|}
\hline $\begin{array}{ll}22 \ldots \\
\text { MAR }\end{array}$ & & 1100 & .7 & 14 & 1 & 1400 & 2 & $v$ & 4 \\
\hline Jifin & 140 & $90 n$ & ${ }^{B}$ & 13 & -- & 1200 & - & 0 & $\cdots$ \\
\hline${ }_{\text {ocr }}^{12 . . .}$ & $\cdots$ & -- & -- & $\cdots$ & -- & 750 & -- & $\cdots$ & -. \\
\hline & - & -- & -- & -- &.$\cdots$ & 1200 & $\cdots$ & 10 & - \\
\hline
\end{tabular}

\begin{tabular}{|c|c|c|c|c|c|c|c|c|c|c|}
\hline L! & 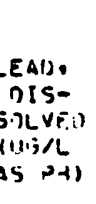 & 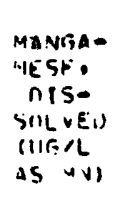 & 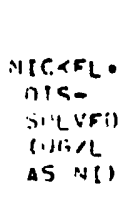 & 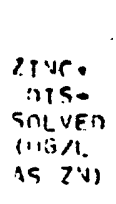 & 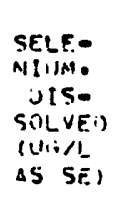 & $\begin{array}{l}\text { SELE- } \\
\text { NIUAS } \\
\text { SHS- } \\
\text { PENIEU } \\
\text { TUTAL } \\
\text { (UINAL } \\
\text { AS SE) }\end{array}$ & 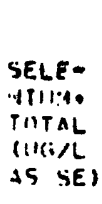 & 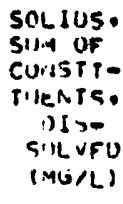 & 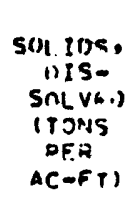 & $\begin{array}{l}\text { NEHCJWY } \\
\text { OISE } \\
\text { SOLVE! } \\
\text { (UG, } \\
\text { IS H(j) }\end{array}$ \\
\hline $\begin{array}{l}E C \cdot 1414 \\
22 \ldots: .1480\end{array}$ & 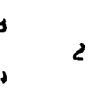 & (اذذه & in & 41) & 0 & -- & $-\infty$ & (U) 31) & 2.76 & " \\
\hline$\cdots$ & $\cdots$ & 310 & - & $2 n$ & -- & -- & 2 & 1650 & $\ddot{z} \cdot P^{4}$ & $\cdots$ \\
\hline & -- & 120 & - & - & 1 & - & - & -- & $\therefore$ & - \\
\hline & $\cdots$ & -- & -- & 10 & 1 & 1 & 2 & -- & -- & - \\
\hline
\end{tabular}




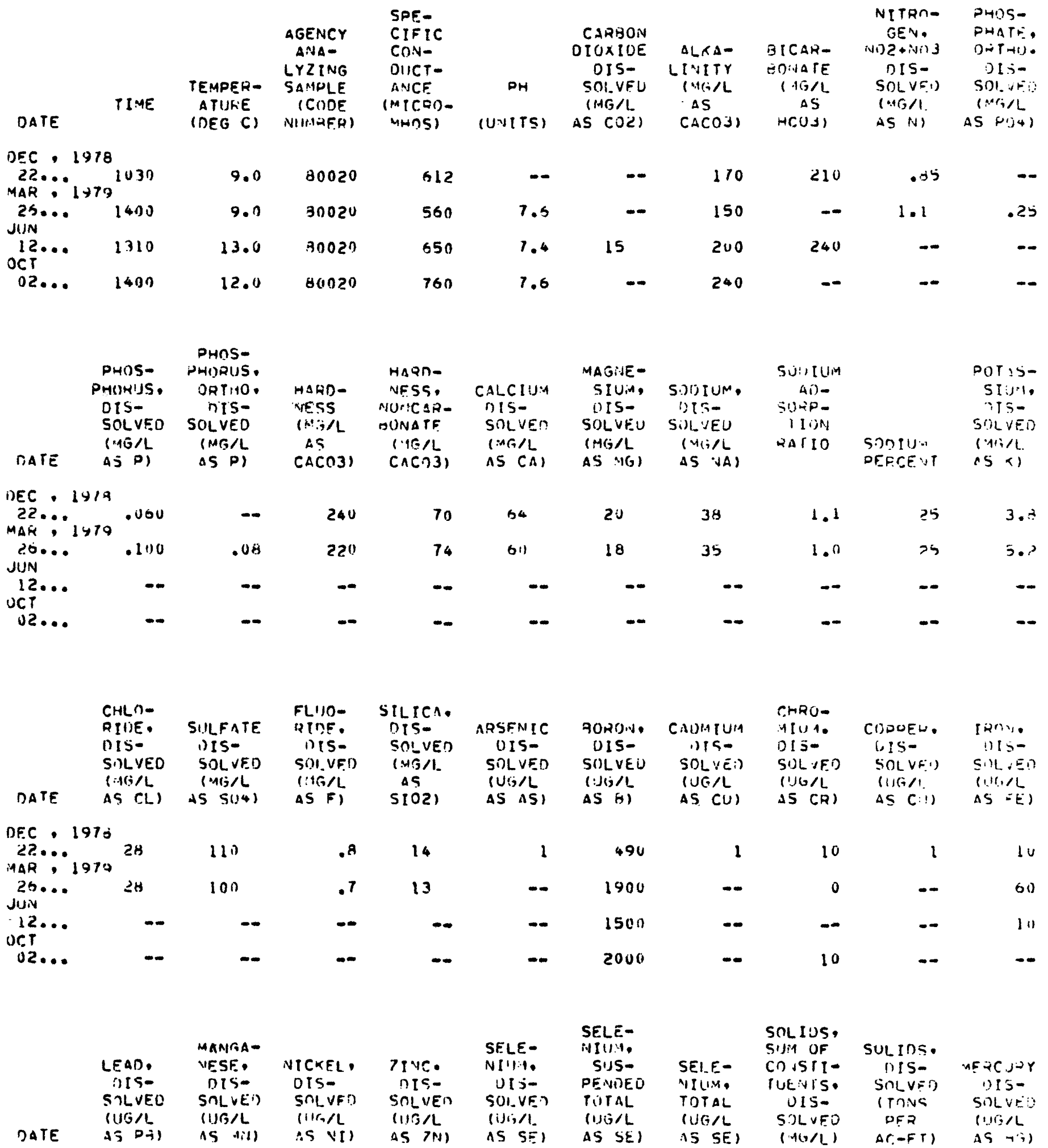

DF.C. 1474

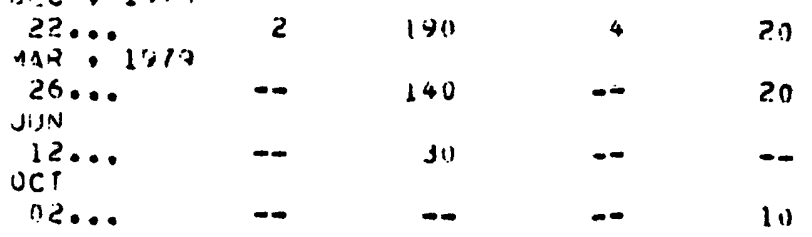


WATER-QUALITY DATA FOR WEIL KS-6, HAYDEN POWERPLANT, HAYDEN, COLO.

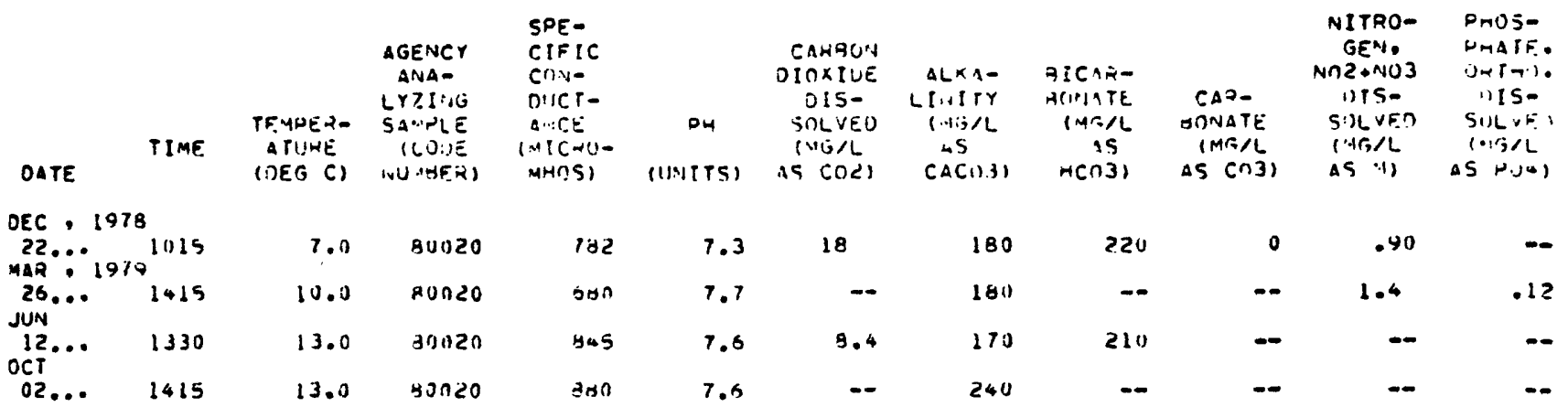

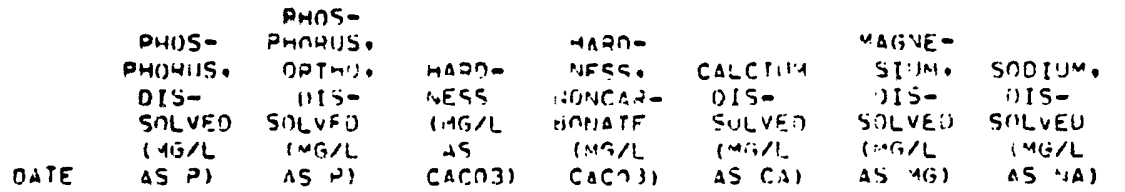

OEC $\cdot 1974$

$32 \ldots$

MAR? 1979

20...

JI:ป

$12 \ldots$

OCT

政

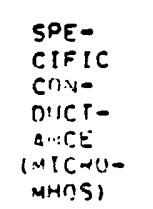

$$
\because
$$

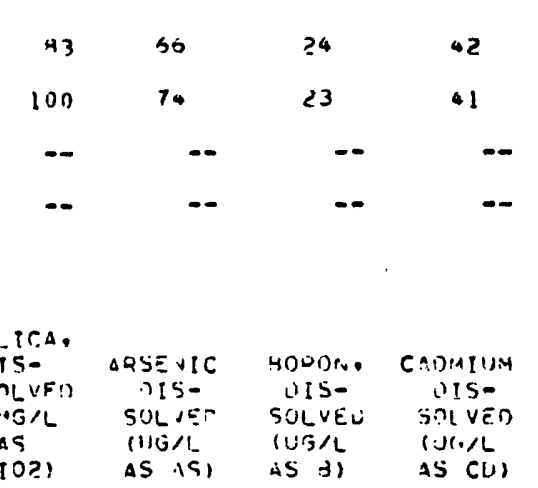

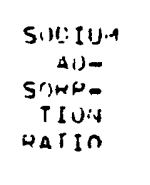

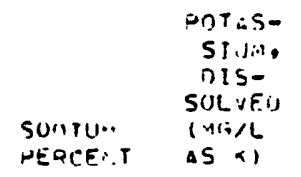
HERCE'T AS KI
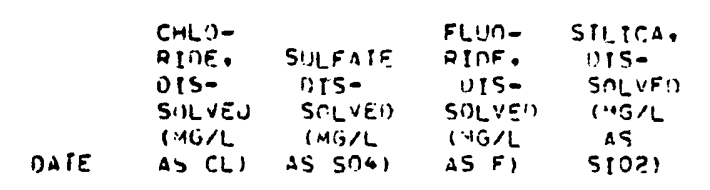
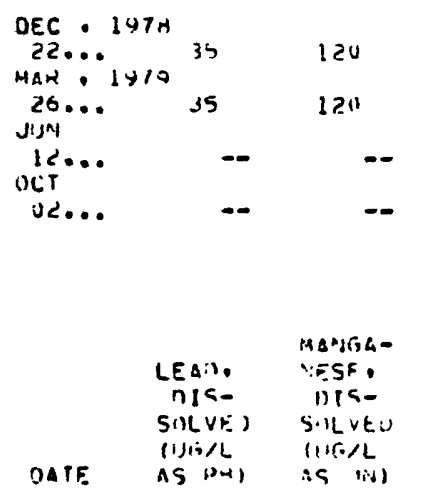

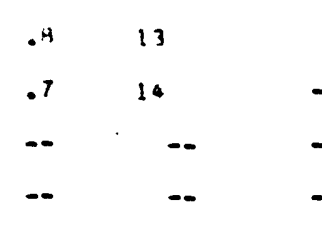

CHUก-

1 I Ui4. 1)1 5 SUL $\checkmark F !$ :116/L QS (R)
CUCOE=. I20". पis- न-ISS(I) Vhu Siblatil (1ii)l luT/L AS (II) AS $F E$ I

DEC - 1915

\begin{tabular}{|c|c|c|c|c|}
\hline ... & 4 & ו:לו & 2 & 20 \\
\hline$\underset{j+\mid A_{1}}{20} \ldots$ & - & 210 & - & 10 \\
\hline IICr. & - & 30 & - & \\
\hline 12. & $-\infty$ & $=-$ & $-\infty$ & 111 \\
\hline
\end{tabular}


WATER-QUALITY DATA FOR WELL HS-7, GAYDEN POWERPLANT, HAYDEN, COLO.

\begin{tabular}{|c|c|c|c|c|c|c|c|c|c|c|c|}
\hline DATE & TIAAE & $\begin{array}{l}\text { TF MPEH- } \\
\text { ATUKE } \\
\text { (DER C) }\end{array}$ & $\begin{array}{l}\text { AGEIVCY } \\
\text { APAD } \\
\text { LYLINIG } \\
\text { SANLLE } \\
\text { (CUIE } \\
\text { NU'AOER) }\end{array}$ & $\begin{array}{l}\text { SPE- } \\
\text { CIFIC } \\
\text { CNR:- } \\
\text { nIICT- } \\
\text { A.VCE } \\
\text { (MICHU- } \\
\text { MUNSI) }\end{array}$ & $\begin{array}{c}\text { PH } \\
\text { (UPITS) }\end{array}$ & $\begin{array}{c}\text { CARBON } \\
\text { DIOXIDE } \\
\text { DIS- } \\
\text { SOLVEI) } \\
\text { (MG/L } \\
\text { AS COL) }\end{array}$ & $\begin{array}{l}\text { ALKA- } \\
\text { LIVITY } \\
\text { (A,G/L } \\
\text { AS } \\
\text { CAC.O3) }\end{array}$ & $\begin{array}{c}\text { AICAR- } \\
\text { HOVATE } \\
\text { (MIN/L } \\
\text { AS } \\
\text { MCR3) }\end{array}$ & $\begin{array}{l}\text { CAR- } \\
\text { DONATE } \\
\text { (MT, } \\
\text { AS CNB) }\end{array}$ & 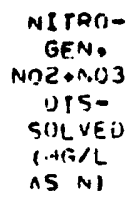 & 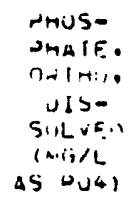 \\
\hline $\begin{array}{l}\text { DEC } \\
22 \ldots \\
\text { MAD }\end{array}$ & $9^{9} 1315$ & $\cdots$ & คunzo & 1350 & 7.6 & 9.6 & 200 & 240 & 0 & 1.1 & $\cdots$ \\
\hline JUN $20 .$. & 1515 & 10.0 & yuilzo & 1110 & 7.5 & - & 220 & - & $-\infty$ & 1.7 & . on \\
\hline${ }_{\text {oct }}^{12} \ldots$ & $(3411)$ & 13.0 & 511020 & 1100 & 7.4 & 13 & 170 & 210 & $-\infty$ & -- & $\cdots$ \\
\hline 02. & 1445 & 14.5 & $84 n 20$ & 1060 & 7.3 & - & 290 & - & -- & $\cdots$ & 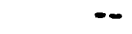 \\
\hline
\end{tabular}

\begin{tabular}{|c|c|c|c|c|c|c|c|c|c|c|}
\hline $\begin{array}{r}D \\
P H \\
D \\
5 \\
1 \\
4\end{array}$ & $\begin{array}{l}\text { PHOS- } \\
\text { HORUS, } \\
\text { OIS- } \\
\text { SOLVEN } \\
\text { (4ij/L } \\
\text { AS DI }\end{array}$ & 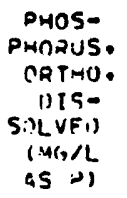 & $\begin{array}{l}\text { HAWD- } \\
\text { AESS } \\
\text { (WriLL } \\
\text { AS } \\
\text { CACn3) }\end{array}$ & 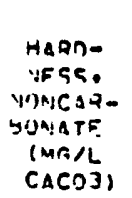 & $\begin{array}{l}\text { CALCTIM } \\
\text { DIS- } \\
\text { SULVEI) } \\
\text { (AHAI. } \\
\text { AS CAI }\end{array}$ & $\begin{array}{l}\text { MASINE- } \\
\text { SIUM. } \\
\text { UIS- } \\
\text { SOLVEU } \\
\text { (M(J/L } \\
\text { AS MG) }\end{array}$ & $\begin{array}{l}\text { SONIU'A. } \\
\text { i)IS- } \\
\text { SOLVEN } \\
\text { (WIE/L } \\
\text { AS AAI) }\end{array}$ & $\begin{array}{l}\text { SUIIIJM } \\
\text { AIJ- } \\
\text { SUIND- } \\
\text { rION } \\
\text { HATIO }\end{array}$ & $\begin{array}{l}\text { SONIU: } \\
\text { Pr:RCE }\end{array}$ & 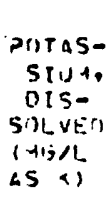 \\
\hline $\begin{array}{l}\text { CEC } 1978 \\
22 . \cdots 1977 \\
\text { MAH } 147\end{array}$ & . 11rv & -- & 511 & 410 & $15 \mathrm{~J}$ & 50 & 41 & 1.5 & 25 & 4.3 \\
\hline Ju!v... & .030 & 00 & 390 & 170 & 100 & 35 & 97 & 2.1 & 35 & $\infty .3$ \\
\hline $\begin{array}{l}12 \ldots . . . \\
\text { oct }\end{array}$ & $\cdots$ & - & - & $-\infty$ & - & -- & - & -- & -- & $\because$ \\
\hline $02 \ldots$ & $-\infty$ & $-\infty$ & $-\infty$ & -- & - & -- & - & $-\infty$ & $\infty$ & - \\
\hline
\end{tabular}

\begin{tabular}{|c|c|c|c|c|c|c|c|c|c|c|}
\hline & $\begin{array}{l}\text { CHLOD- } \\
\text { RIDE. } \\
\text { OIS- } \\
\text { SOLVEU } \\
\text { IWG L }\end{array}$ & $\begin{array}{l}\text { SULF A IE } \\
\text { nIS- } \\
\text { SULVEO } \\
\text { SNG/L }\end{array}$ & 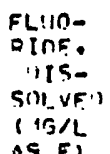 & $\begin{array}{l}\text { SIIICA, } \\
\text { OIS- } \\
\text { SnLVFA } \\
\text { SHGSIL } \\
\text { AS }\end{array}$ & $\begin{array}{c}\text { ARSEATC } \\
\text { ') (S- } \\
\text { SILVEI) } \\
\text { (UGAI. }\end{array}$ & $\begin{array}{l}\text { MINUUI. } \\
\text { UIS- } \\
\text { SULVEL } \\
\text { IUIJLL }\end{array}$ & $\begin{array}{c}\text { CAOMIUM } \\
\text { DIS- } \\
\text { SOLVEO } \\
\text { I!UM }\end{array}$ & 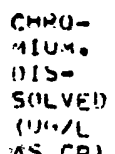 & 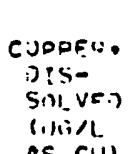 & 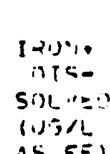 \\
\hline & & & & & & & & & & \\
\hline
\end{tabular}

\begin{tabular}{|c|c|c|c|c|c|c|c|c|c|c|}
\hline $\begin{array}{l}\text { UEC : 1978 } \\
\text { E2. ‥ } \\
\text { MAR } 1479\end{array}$ & Ho & 450 & .6 & 19 & J & 400 & $l$ & 10 & 4 & 10 \\
\hline $\begin{array}{l}26 \ldots \\
\text { JUN }\end{array}$ & 53 & $28 n$ & - h & 19 & $\infty$ & 2000 & - & u & $\cdots$ & 0 \\
\hline $\operatorname{oct}^{12} \cdots$ & - & $\cdots$ & - & - & -- & 230 & $\cdots$ & - & -- & \\
\hline $02 \ldots$ & $\infty$ & $\infty$ & $\ldots$ & - & -- & 1800 & - & $u$ & $=-$ & \\
\hline
\end{tabular}

\begin{tabular}{|c|c|c|c|c|c|c|c|c|c|c|}
\hline nATE. & 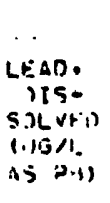 & 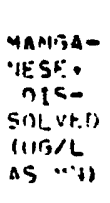 & 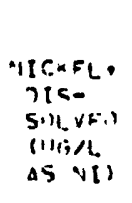 & 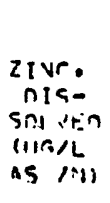 & $\begin{array}{l}\text { SFLE- } \\
\text { NiIN" } \\
\text { (IIS- } \\
\text { SIULE!) } \\
\text { (UISAL. } \\
\text { AS SF.) }\end{array}$ & 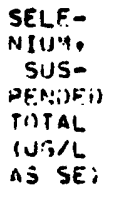 & 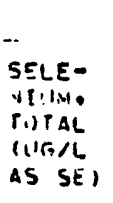 & 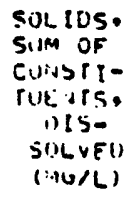 & 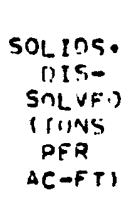 & 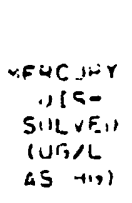 \\
\hline $\begin{array}{l}\text { DEC . } \\
\text { ¿2. } \\
\text { :AK }\end{array}$ & 2 & 210 & 5 & 311 & 4 & $-\infty$ & - & 974 & 1.32 & $"$ \\
\hline $\begin{array}{lll}2 n . & \\
\text { Jul } & \end{array}$ & - & 10 & $-\infty$ & 20 & 3 & $-\infty$ & $\cdots$ & 730 & .90 & -- \\
\hline $\begin{array}{l}12 \ldots \\
.18\end{array}$ & $\cdots$ & 20 & -- & $\cdots$ & 3 & $-\infty$ & $\cdots$ & - & $\cdots$ & \\
\hline 1) $2 \ldots$ & $\cdots$ & $\cdots$ & $\cdots$ & 11 & 5 & $v$ & 5 & -- & $-\infty$ & - \\
\hline
\end{tabular}




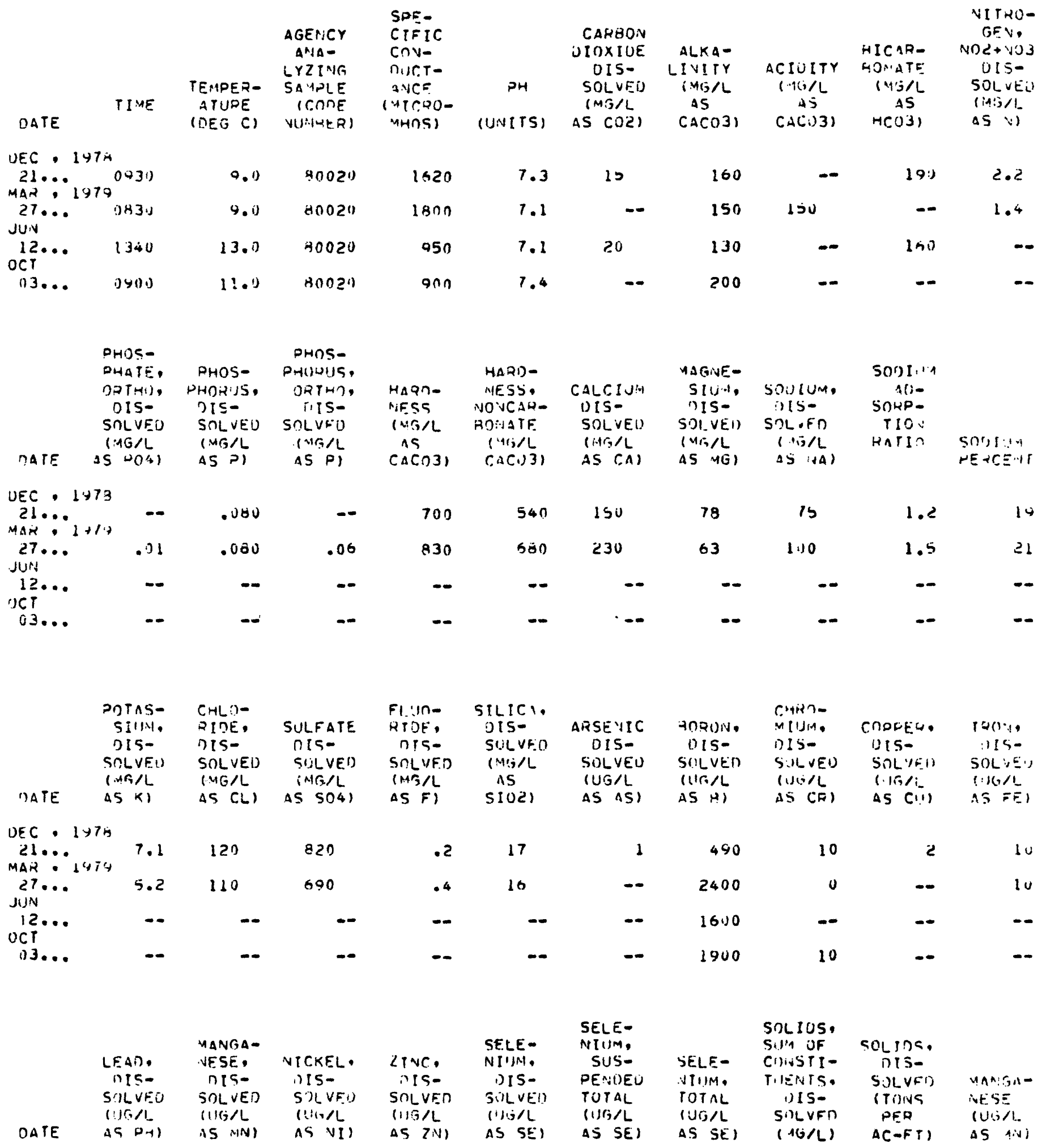


WATER-QCALITY DATA EOR WELL HS-9, HAYDEN POWERPLANT, MAYDEN, COLO.

\begin{tabular}{|c|c|c|c|c|c|c|c|c|c|c|c|}
\hline DATE & TIHE & $\begin{array}{l}\text { TEYDEN- } \\
\text { ATUHF } \\
\text { (UEG C) }\end{array}$ & $\begin{array}{l}\text { AGENCY } \\
\text { ANA- } \\
\text { LYZINGG } \\
\text { SA ARLE } \\
\text { ICIJIE } \\
\text { NUAAEAI }\end{array}$ & $\begin{array}{l}\text { SPE- } \\
\text { CIFIC } \\
\text { CONE } \\
\text { NIICT- } \\
\text { A ICE } \\
\text { (NICY)- } \\
\text { MHOS) }\end{array}$ & $\begin{array}{c}D H \\
\text { (UVITS) }\end{array}$ & $\begin{array}{c}\text { CAHAUN } \\
\text { OIOXIOE } \\
\text { OIS- } \\
\text { SOLVES } \\
\text { 1'AG/L } \\
\text { AS COLI }\end{array}$ & $\begin{array}{l}\text { ALKA- } \\
\text { LMITY } \\
(M U / L \\
\text { IS } \\
\text { CACI) } 3)\end{array}$ & $\begin{array}{c}\text { QICADE } \\
\text { OUVATE } \\
\text { IMCAL } \\
\text { AS } \\
\text { HCi13) }\end{array}$ & $\begin{array}{l}\text { CADE } \\
\text { WOIVATE } \\
\text { (AAr, } \\
\text { AS COS) }\end{array}$ & $\begin{array}{l}\text { NITRO- } \\
\text { GE"N, } \\
\text { NOLANO3 } \\
\text { JIS- } \\
\text { SULVED } \\
\text { IASML } \\
\text { AS WI }\end{array}$ & 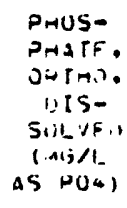 \\
\hline $\begin{array}{l}\text { JEC }, \\
21 . \cdots\end{array}$ & $9^{3} 1110$ & $5 . n$ & Ho020 & 1070 & 7.6 & 11 & 2311 & 200 & 0 & 2.1 & - \\
\hline JUN & 0४ט० & 10.0 & sunzo & 1150 & 7.8 & -- & 240 & -- & - & 3.6 & .03 \\
\hline${ }_{\text {oct }}^{12} \ldots$ & I350 & 13.0 & BU(1) & 1410 & 7.6 & 12 & 250 & 300 & - & -- & - \\
\hline $03 \ldots$ & 0945 & 11.0 & $\because n 020$ & $14 \cup 0$ & 7.6 & -- & $3 n n$ & $\cdots$ & -- & -- & - \\
\hline
\end{tabular}

\begin{tabular}{|c|c|c|c|c|c|c|c|c|c|c|}
\hline DATE & $\begin{array}{l}\text { PHUS- } \\
\text { PHANIIS, } \\
\text { DIS- } \\
\text { SOLVEO } \\
\text { (WT/L } \\
\text { AS } 12)\end{array}$ & 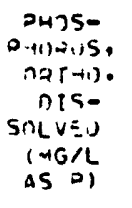 & 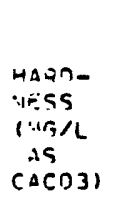 & 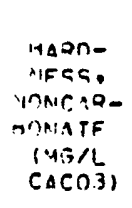 & $\begin{array}{l}\text { CALCTIMA } \\
\text { nIS- } \\
\text { SOLVFO } \\
\text { IMrAII } \\
\text { AS CA) }\end{array}$ & $\begin{array}{l}\text { MQSNEE- } \\
\text { STUM, } \\
\text { UIS- } \\
\text { SULVEU } \\
\text { (NG/L } \\
\text { AS IMG) }\end{array}$ & 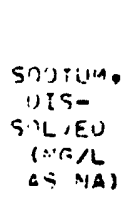 & $\begin{array}{l}\text { SU'?TUM } \\
\text { AIX- } \\
\text { S.JMP- } \\
\text { TIUN } \\
\text { RAIIO }\end{array}$ & $\begin{array}{l}\text { SOOIU: } \\
\text { OF.RCE:ST }\end{array}$ & $\begin{array}{l}\text { POTAS- } \\
\text { SI!:A, } \\
\text { DIS- } \\
\text { STLVE, } \\
\text { IAE/l. } \\
\text { AS (I) }\end{array}$ \\
\hline $\begin{array}{c}\text { DEC } \\
21 \ldots \\
M A R\end{array}$ & $174.0 \div 6$ & $-\infty$ & 440 & 250 & 95 & 60 & 17 & 1.5 & 25 & 3 \\
\hline $\begin{array}{l}27 . . \\
\sin \end{array}$ & . 1) 30 & .01 & 550 & 310 & 110 & 37 & 78 & 1.4 & 23 & 4 \\
\hline${ }_{\text {OCT }}^{12} \cdots$ & $\cdots$ & $\cdots$ & -- & -- & -- & $\infty$ & $\cdots$ & -- & -- & \\
\hline 43. & - & -- & -- & -- & - & -- & -- & -- & - & - \\
\hline
\end{tabular}

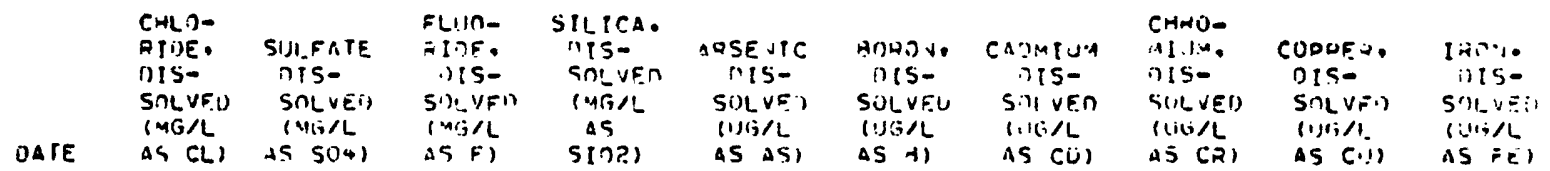

\begin{tabular}{|c|c|c|c|c|c|c|c|c|c|c|}
\hline $21 \ldots 901+19$ & 49 & 35i) & .9 & 17 & 1 & 1600 & 1 & 10 & 3 & $2 v$ \\
\hline jum $27 \ldots$ & 57 & 350 & .9 & 13 & -- & 1700 & $\ldots$ & 10 & $-\infty$ & 20 \\
\hline$\underset{n c r}{12} \cdots$ & -- & $\cdots$ & -- & - & - & 1900 & $-\infty$ & -- & -- & 0 \\
\hline 03... & - & -- & $\cdots$ & - & -- & 1400 & -- & 10 & - & \\
\hline
\end{tabular}

\begin{tabular}{|c|c|c|c|c|c|c|c|c|c|c|}
\hline DAIE & $\begin{array}{l}\text { LFAD, } \\
\text { OIIS- } \\
\text { SILVEL } \\
(11,1) \\
+5 P \cdot 3)\end{array}$ & 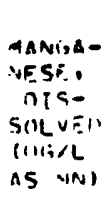 & 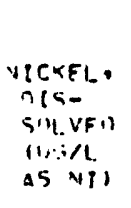 & 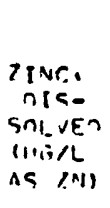 & 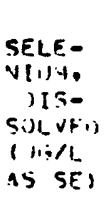 & 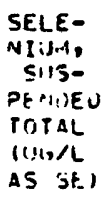 & $\begin{array}{l}\text { SELE- } \\
\text { NPINA } \\
\text { PUTAL } \\
\text { IULIL } \\
\text { AS SES }\end{array}$ & 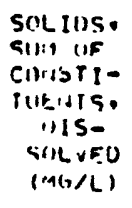 & $\begin{array}{c}\text { SOL InA. } \\
\text { DIS- } \\
\text { SOLVE.' } \\
\text { (TONS } \\
\text { GFZ } \\
\text { AC-FT) }\end{array}$ & 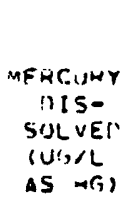 \\
\hline $\begin{array}{l}\text { OEC . } \\
21 . \cdots \\
\operatorname{mat}\end{array}$ & 4 & 71 & 2 & $3 n$ & 4 & - & - & nח & 1.99 & . \\
\hline 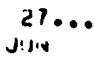 & -- & 11:1 & -- & $2 n$ & $\epsilon$ & - & $\cdots$ & HAS & 1.15 & - \\
\hline 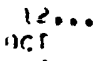 & - & +11 & $-\infty$ & - & 4 & -. & $-\infty$ & - & -- & -- \\
\hline ט.... & -- & -- & -- & 0 & 4 & v & 4 & -- & - & - \\
\hline
\end{tabular}


WATER-QUALITY DATA FOR WELL HS-10, HAYDEN POWERPLANT, HAYDEN, COLO.

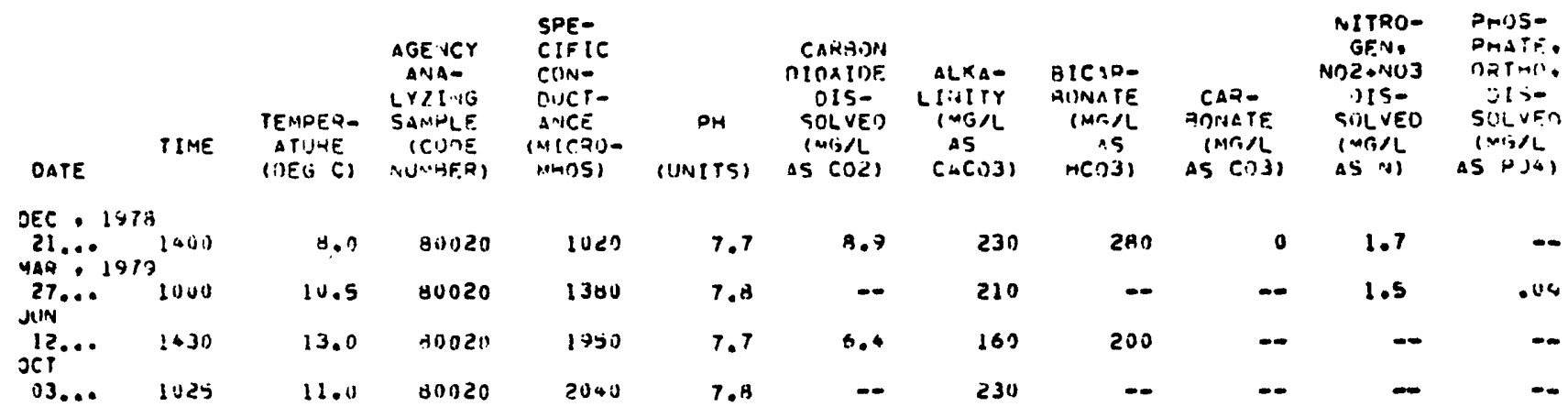

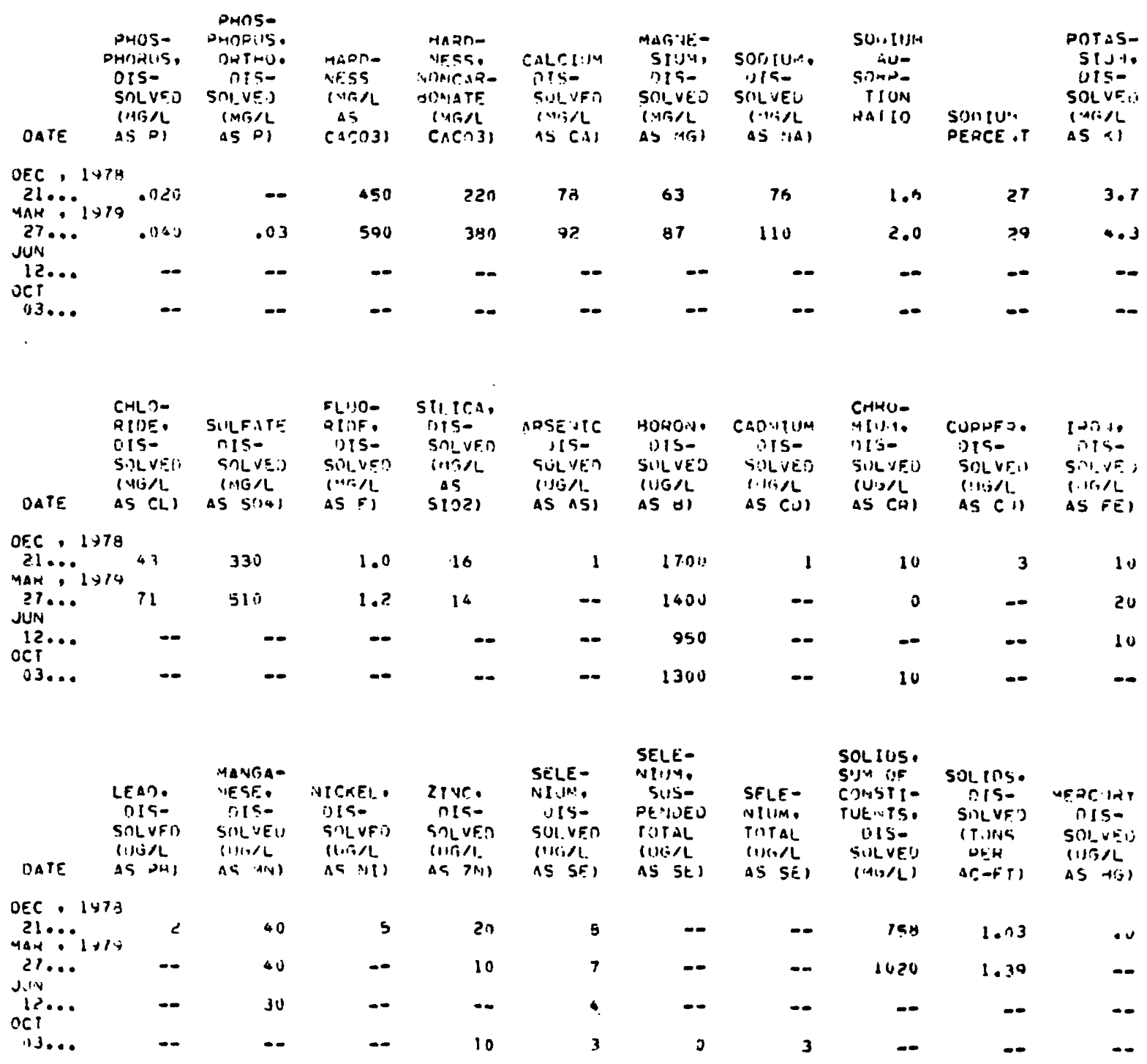


WATER-QUALITY DATA FOR WELL HS-11, HAYDEN POWERPLANT, HAYDEN, COLO.

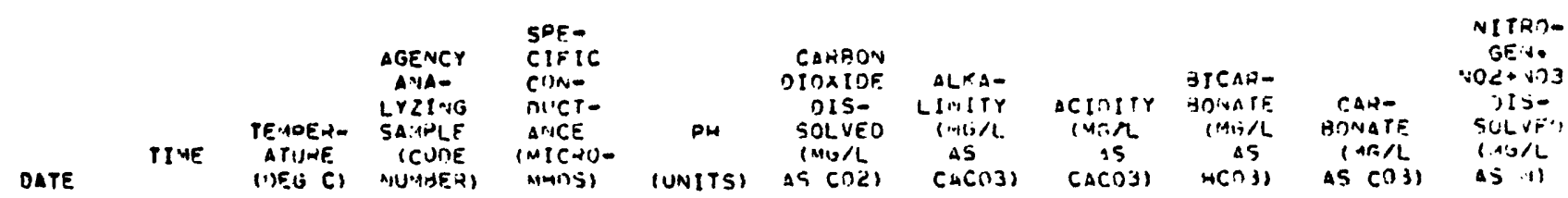

JEC $\cdot 1978$

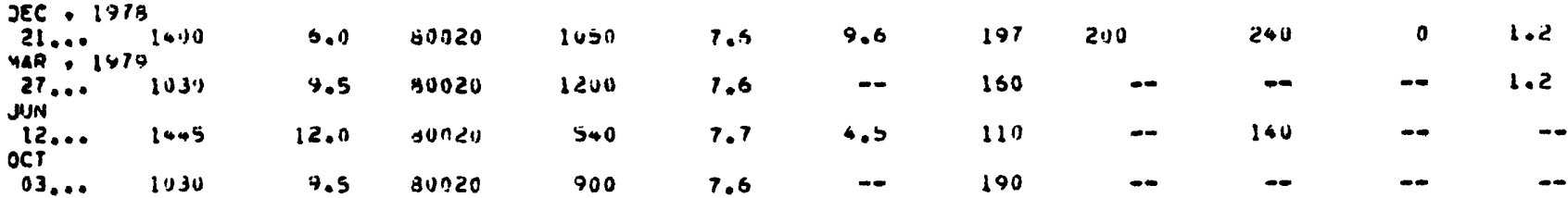

\begin{tabular}{|c|c|c|c|c|c|c|c|c|c|c|c|}
\hline & $\begin{array}{l}\text { PHOS- } \\
\text { PHATE, } \\
\text { OQIAN. } \\
\text { DIS- } \\
\text { SOLVED } \\
\text { IMUNL }\end{array}$ & 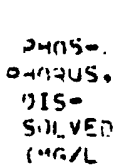 & 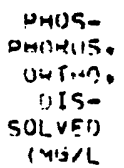 & $\begin{array}{l}4 A D)= \\
A 15 S 5 \\
1 \times 5 / L \\
A 5\end{array}$ & 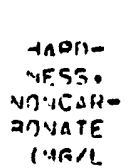 & $\begin{array}{l}\text { CALCIUIA } \\
\text { IIS- } \\
\text { SOLYEO } \\
\text { IUISLL }\end{array}$ & 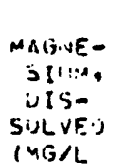 & 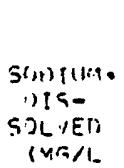 & $\begin{array}{c}\text { Sorilum } \\
\text { aU- } \\
\text { SIIñ- } \\
\text { T(1).V } \\
\text { QATIO }\end{array}$ & & 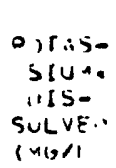 \\
\hline & AS Pval & as 15 & AS PI & $(n(0) 3)$ & Cacn 31 & AS CAl & as $\mid[j \mid$ & AS NAI & & FACEVT & $65 \times 1$ \\
\hline
\end{tabular}

\begin{tabular}{|c|c|c|c|c|c|c|c|c|c|c|c|}
\hline $\begin{array}{l}\text { OEC } 1973 \\
21 \cdots \cdots \\
\text { 4Aं2 } 1473\end{array}$ & -- & .090 & - & 430 & 240 & 98 & 46 & 76 & 1.6 & 27 & 4.9 \\
\hline$\underset{j i, N}{27} \bullet \cdots$ & I I & . uso & .06 & 510 & 350 & $1<U$ & 51 & 97 & 1.7 & 27 & S.n \\
\hline $\mathrm{OCT}^{12} \cdots$ & $-\infty$ & - & - & - & $-\infty$ & & & & - & - & - \\
\hline a3... & $-\infty$ & $=-$ & $-\infty$ & $-\infty$ & -- & & & & - & - & \\
\hline
\end{tabular}

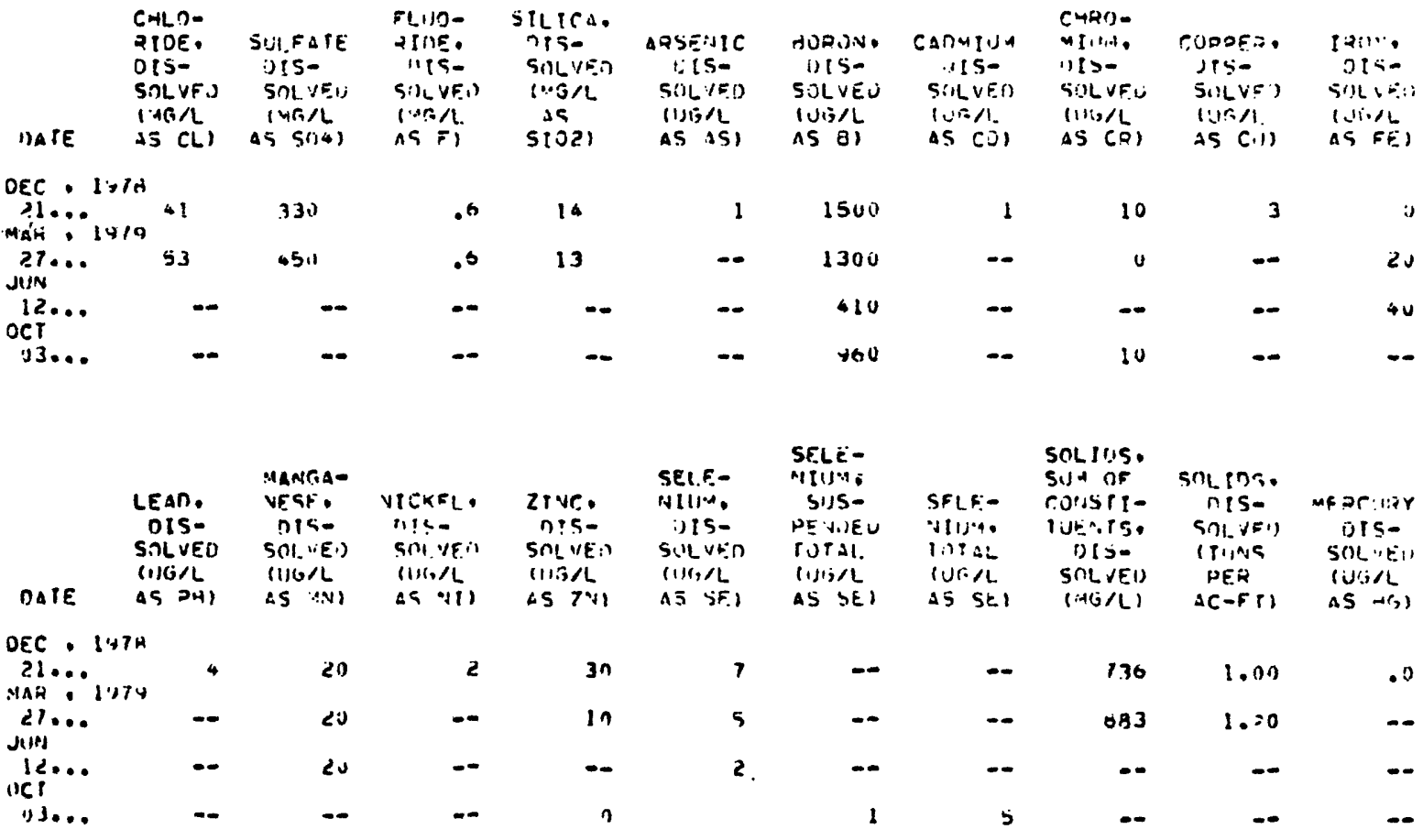


WATER-QUALITY DATA FOR WELI HS-12, HAYDEN POWERPLANT, HAYDEN, COLO.

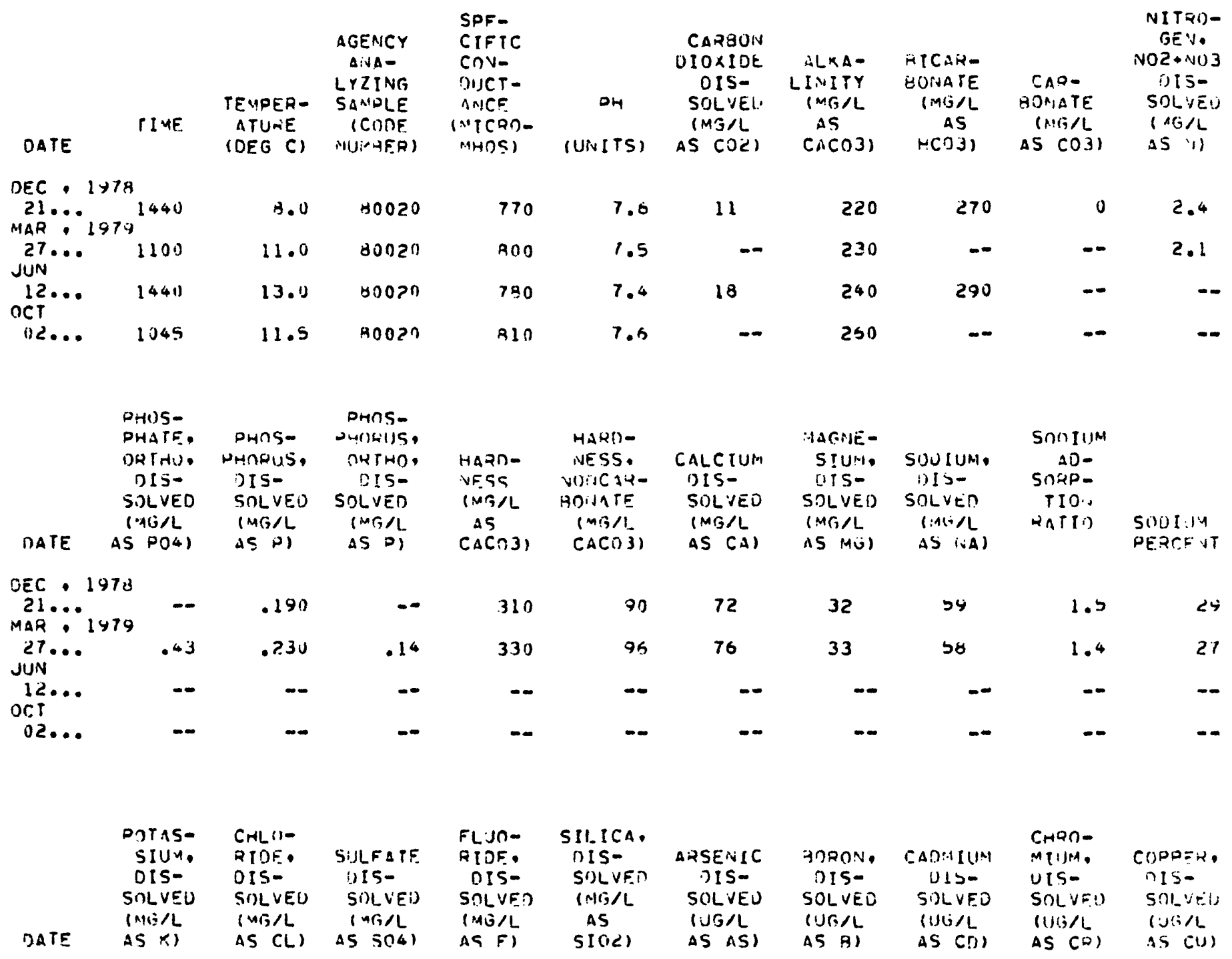

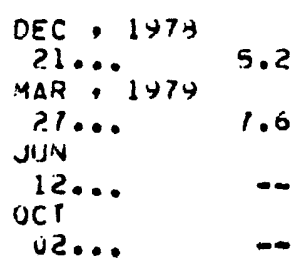

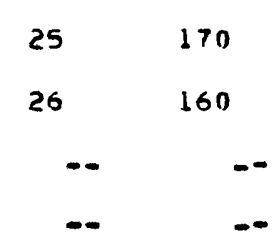

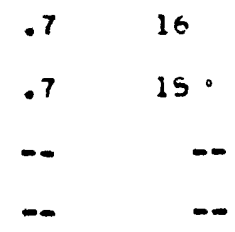

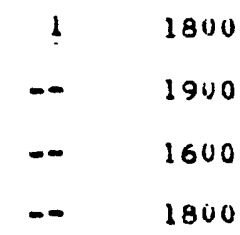

SELE-

i) 1 (I.M.

กIS-

SOLVEU

(I!)
SELF-

illiM,

TOTAL

BURAL AS VI) AS (UI) AS SE) IS SE) (HG/L) AC-FT) AS T(I) AS VI) AS (UI) AS SE) IS SE) (HG/L) AC-FT) AS T(I)

SOLIOS, SUA OF CONSTTTUENTS. UISSOLVEU AS VI) AS (UI) AS SE) IS SE) (HG/L) AC-FT) AS T(I)

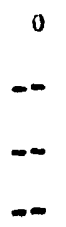

$-$
10

10

10

DEC , 147म

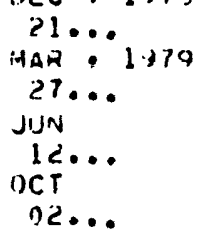

$\begin{array}{lll}0 & 2 & 80 \\ 50 & \ldots & 70 \\ 20 & \ldots & 51 \\ -- & \ldots & -0\end{array}$

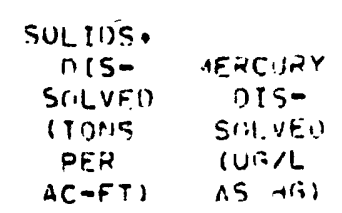

SULIIŚS. त(STIONIS AS VIS AS (VI) AS SE) IS SE) (HG/L) AC-FT) AS A(I)
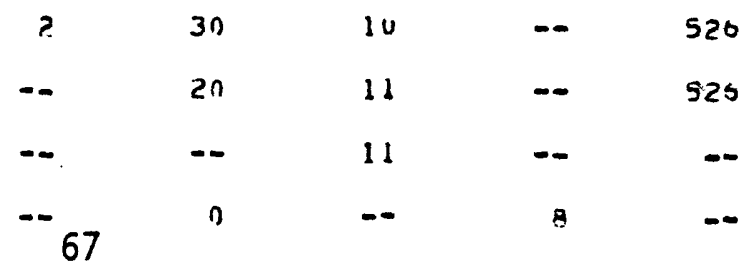
WATER-QUALITY DATA FOR NELL HS-13, HAYDEN POWERPLANT, HAYDEN, COLO.

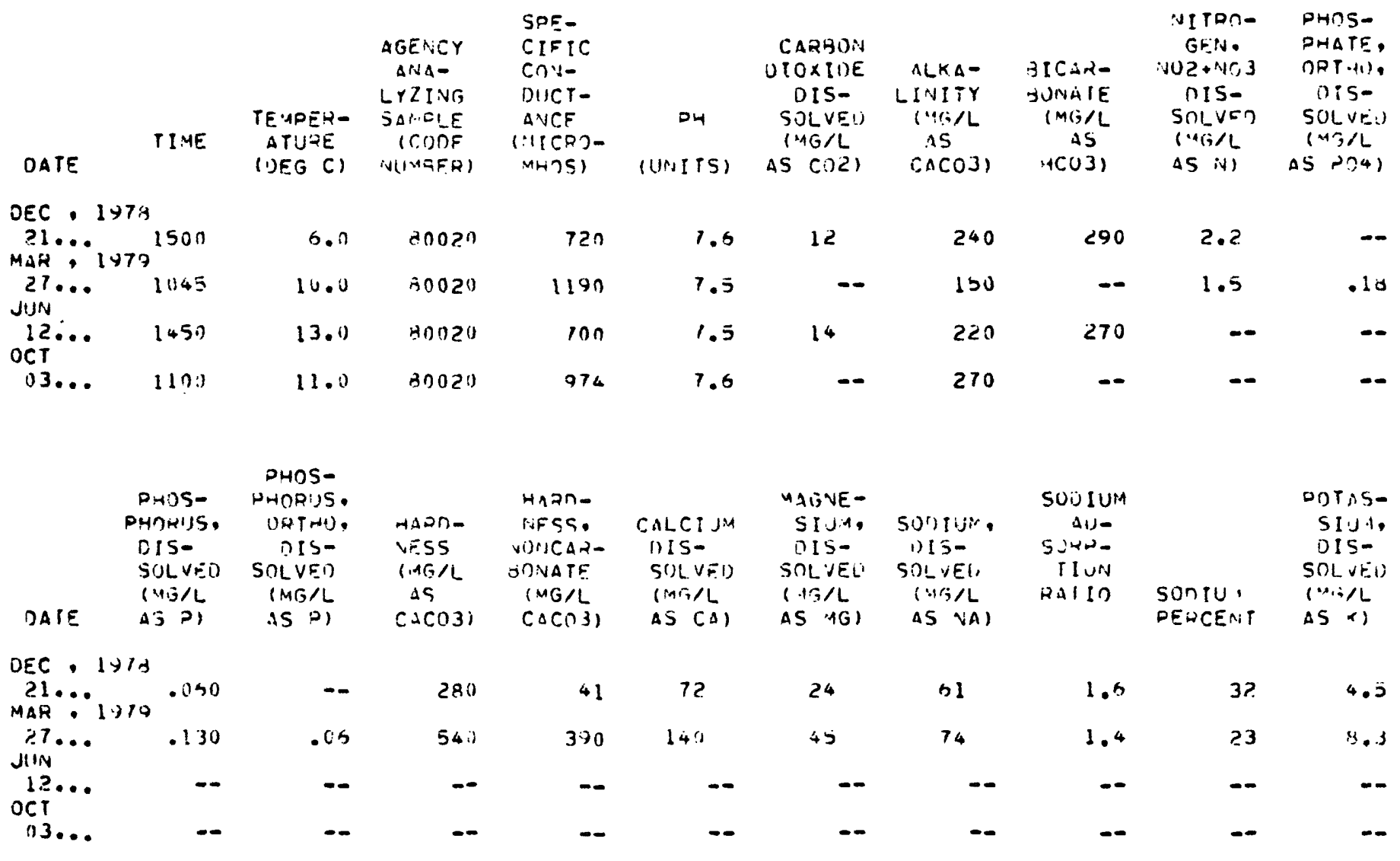

\begin{tabular}{|c|c|c|c|c|c|c|c|c|c|}
\hline & $\begin{array}{l}\text { CHLOO- } \\
\text { PIDE }\end{array}$ & JLF $\triangle T F$ & $\begin{array}{l}\text { ELUUE- } \\
\text { RIDF., }\end{array}$ & $\begin{array}{l}\text { SIIIICA. } \\
\text { DIS- }\end{array}$ & & & & $\begin{array}{l}\text { Cripn- } \\
\text { MIIN", }\end{array}$ & \\
\hline & SOLVED & Sul & ofs- & $\begin{array}{l}\text { SnLVER } \\
\text { IMG/L }\end{array}$ & 50 & su & & E(I) & En \\
\hline & $\cap S(L)$ & $\begin{array}{r}\text { (M) } \\
\text { AS SO14! }\end{array}$ & $\begin{array}{l}(1 / i / L \\
\Delta S-F)\end{array}$ & $\begin{array}{l}15 \\
\sin (0)\end{array}$ & $\begin{array}{l}(1)(1 / 2 \\
\text { is } A S)\end{array}$ & $\begin{array}{l}\text { (UIM/L } \\
\text { AS A) }\end{array}$ & $\begin{array}{l}(U r i / L \\
\text { AS (D) }\end{array}$ & $\begin{array}{l}(i J R / L \\
\text { AS } C K)\end{array}$ & $\begin{array}{l}1.16 / 1 \\
\text { is cist }\end{array}$ \\
\hline
\end{tabular}

\begin{tabular}{|c|c|c|c|c|c|c|c|c|c|}
\hline $21 \cdots$ & 21 & 150 & .6 & 16 & 1 & $140 n$ & 1 & 10 & 2 \\
\hline JUN 27 & 50 & 430 & .5 & 14 & -- & 20011 & $\cdots$ & 10 & \\
\hline${ }_{0<T}^{12} \cdots$ & -- & $-\infty$ & -- & -- & -- & 110.3 & -- & -- & \\
\hline $03 \ldots$ & - & $=$ & -- & - & - & 1400 & $-\infty$ & 10 & \\
\hline
\end{tabular}

\begin{tabular}{|c|c|c|c|c|c|c|c|c|c|}
\hline & & & MANGA- & & & SELE- & & $\begin{array}{l}\text { SOLIINS, } \\
\text { SUM OF }\end{array}$ & SOLIDS, \\
\hline & $\begin{array}{l}\text { IRON, } \\
\text { OIS- }\end{array}$ & $\begin{array}{l}\text { LEAII, } \\
\text { UIS- }\end{array}$ & $\begin{array}{l}\text { MESE, } \\
\text { JIS- }\end{array}$ & $\begin{array}{l}\text { "ICKFL. } \\
\text { DIS- }\end{array}$ & $\begin{array}{l}7 \text { live, } \\
\text { nis- }\end{array}$ & $\begin{array}{l}\text { NIINM, } \\
\text { UIS- }\end{array}$ & $\begin{array}{l}\text { SELE- } \\
\text { IYILM. }\end{array}$ & CONSTI- & DIS- \\
\hline & SOLVED & $S \cap L D E O$ & SOLVEN & SOLVE? & SOLVED & SULVFn & Toral. & ols- & (T):55 \\
\hline & IUG/L & $(11) / L$ & $\{U i / L$ & CUSA & UU⿴囗L & (uij/ & $(11: 2)$ & SOLVEÍ) & NEK \\
\hline & AS FEI & 25241 & $\left.A^{5} 5: 1,4\right)$ & 45 III & 15 (id) & AS SE) & AS SEI & $(N G / L)$ & $(C-F()$ \\
\hline
\end{tabular}

DEC - 1भात

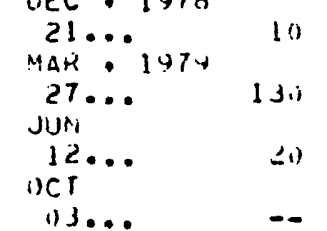

$\begin{array}{rrrr}2 & 40 & 2 & 10 \\ -- & 30 & -- & 20 \\ -- & 140 & -- & - \\ -- & -- & -- & 10\end{array}$

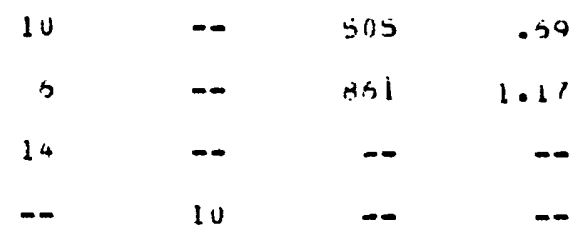


WATER-QUALITY DATA FOR WELL HS-15, HAYDEN POWERPLANT, HAYDEN, COLO.

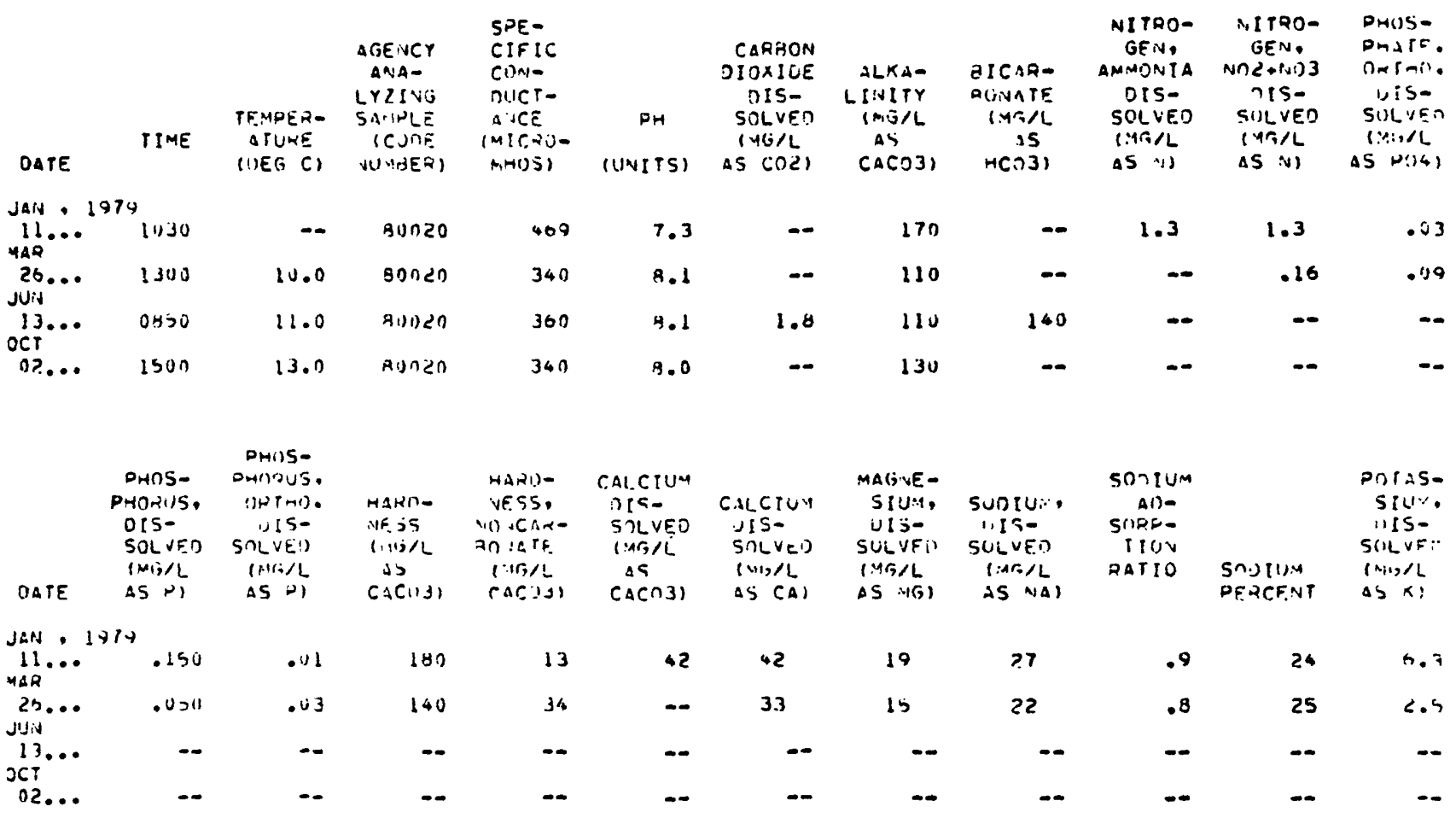

\begin{tabular}{|c|c|c|c|c|c|c|c|c|c|c|c|}
\hline & 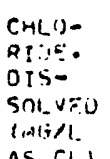 & $\begin{array}{l}\text { SUF॥IE } \\
\text { US- } \\
\text { SULVE.) } \\
1 \text { "U, }\end{array}$ & 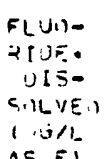 & 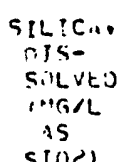 & 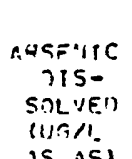 & 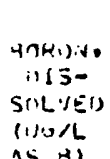 & $\begin{array}{c}\text { CAIMLIIM } \\
\text { UIS- } \\
\text { SULAL, } \\
\text { IUG/L } \\
\text { AS (D) }\end{array}$ & 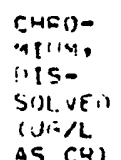 & 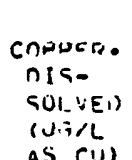 & 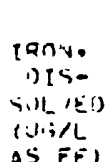 & 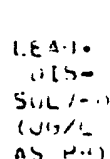 \\
\hline ATE & AS CLI & AS $\$ 0+1$ & $45 F I$ & SIOLI & (5 $(5)$ & प5 मा & as (i) & $\Delta S(4)$ & AS (U) & is FE. & n) \\
\hline
\end{tabular}

\begin{tabular}{|c|c|c|c|c|c|c|c|c|c|c|c|}
\hline${ }_{\text {MAR }} 11 .$. & 13 & $4 \pi$ & .7 & 11 & 2 & 1100 & 1 & 0 & b & 300 & 2 \\
\hline$\underset{j ! N}{25 . . .}$ & 4.4 & o & .8 & +.2 & -- & $\$ 80$ & -- & 0 & - & 20 & -- \\
\hline 13... & $\cdots$ & $\cdots$ & $\cdots$ & $\cdots$ & $\infty$ & 610 & - & -- & -- & 120 & - \\
\hline $02 \ldots$ & $\cdots$ & $\cdots$ & - & $\cdots$ & -- & 300 & -- & 10 & $\cdots$ & $\ldots$ & \\
\hline
\end{tabular}

\begin{tabular}{|c|c|c|c|c|c|c|c|c|c|c|}
\hline DATE & $\begin{array}{l}\text { MAIVGA- } \\
\text { NESF. } \\
\text { OIS- } \\
\text { SILVEU } \\
\text { IIISAL } \\
\text { Aj IS }\end{array}$ & $\begin{array}{l}\text { NICKFL. } \\
\text { i)IS- } \\
\text { SOLJE } \\
\text { (1ISAL } \\
\text { IS II) }\end{array}$ & 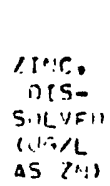 & 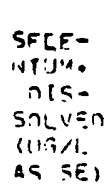 & 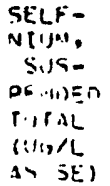 & $\begin{array}{l}\text { SELE- } \\
\text { NIUNA } \\
T \text { TOLL } \\
\text { (UIBLL } \\
\text { AS SE) }\end{array}$ & $\begin{array}{l}\text { SOLIDS. } \\
\text { SUY UF } \\
\text { CNVSTI- } \\
\text { TUE. IS. } \\
\text { i) IS- } \\
\text { SUVEI) } \\
\text { (MG/L) }\end{array}$ & 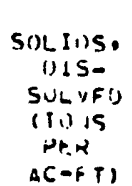 & 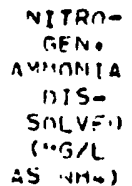 & 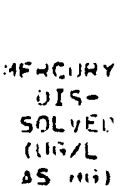 \\
\hline Jav. & & & & & & & & & 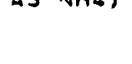 & \\
\hline $\operatorname{MAn}_{41} \cdots$ & 121 & j & $3 n$ & $\circ$ & -. & -- & 277 & . 3H & 1.7 & .0 \\
\hline $\begin{array}{l}20 . \cdots \\
\text { juv }\end{array}$ & 1) & $\cdots$ & 10 & 2 & - & - & 205 & Bج?. & - & -. \\
\hline$\left.{ }_{\text {oc }}^{13}\right\}^{3} \cdots$ & $v$ & $-\cdot$ & -- & 1 & - & -- & -- & $-\infty$ & - & $-\infty$ \\
\hline ve... & $\cdots$ & $\cdots$ & 1 & ! & 1 & $<$ & - & $-\infty$ & - & - \\
\hline
\end{tabular}




\begin{tabular}{|c|c|c|c|c|c|c|c|c|c|c|}
\hline DATE & TIME & $\begin{array}{l}\text { TEMPER- } \\
\text { ATURE } \\
\text { (DEG C) }\end{array}$ & $\begin{array}{l}\text { AGEMCY } \\
\text { ANA- } \\
\text { LYZIVG } \\
\text { SAMPLF } \\
\text { (COINE } \\
\text { M(I:ALED) }\end{array}$ & $\begin{array}{l}\text { SPE- } \\
\text { CIFIC } \\
\text { CON- } \\
\text { DUICT- } \\
\text { ANCFF } \\
\text { (MIC:ON- } \\
\text { (HHIS) }\end{array}$ & $\begin{array}{c}P H \\
\text { (IJijITS) }\end{array}$ & $\begin{array}{c}\text { CAUHON } \\
\text { OIOXIDE } \\
\text { OIS- } \\
\text { SULVED } \\
(M(M / L \\
\text { AS COLS }\end{array}$ & $\begin{array}{c}\text { HLKA- } \\
\text { LITTY } \\
\text { I:AF/L } \\
\Delta S \\
\text { CAC,OB) }\end{array}$ & $\begin{array}{c}\text { AICAR- } \\
\text { MUINATE } \\
\text { R:AG/L } \\
\text { AS } \\
\text { HCUS\} }\end{array}$ & 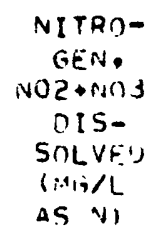 & $\begin{array}{c}\text { PHOS- } \\
\text { PHATE, } \\
\text { ORTHI), } \\
\text { OIS- } \\
\text { S(IIVEL } \\
(M(I / L \\
\text { AS PO4) }\end{array}$ \\
\hline \multicolumn{11}{|c|}{ JAN, 1919} \\
\hline $\begin{array}{l}12 \ldots . . \\
M \Delta R\end{array}$ & 1155 & -- & 800210 & $117 n$ & 7.3 & -- & 530 & - & 2.5 & -- \\
\hline$\underset{\text { JUN }}{27} \cdots$ & 1350 & 10.0 & 80020 & 520 & 7.1 & $-\infty$ & 180 & - & 1.2 & .00 \\
\hline oct & 0901) & 13.0 & $\left.9002^{0}\right)$ & 580 & 7.1 & 32 & 210 & 250 & -- & - \\
\hline $02 \ldots$ & 1545 & PHOS- & 90020 & 850 & 7.0 & -- & 330 & - & -- & -- \\
\hline & $\begin{array}{l}\text { PHUS- } \\
\text { PHORISS } \\
\text { OIS- } \\
\text { SOLVED } \\
\text { IMULL }\end{array}$ & $\begin{array}{c}\text { PHORUS, } \\
\text { ORTHO) } \\
\text { OIS- } \\
\text { SOLVFI) } \\
\text { (MFIL }\end{array}$ & $\begin{array}{l}\text { HARN- } \\
. I E S S \\
1+1 F / L \\
\triangle S\end{array}$ & $\begin{array}{l}\text { HARN- } \\
\text { DESS, } \\
\text { INNCAR- } \\
\text { DONATE } \\
\text { IMGLL }\end{array}$ & $\begin{array}{l}\text { CALCTUS } \\
\text { 1)IS- } \\
\text { SOLVEO } \\
\text { CMCAL }\end{array}$ & $\begin{array}{l}\text { MAGNE- } \\
\text { SIIM, } \\
\text { IIS- } \\
\text { SOLVEU } \\
\text { ING/L }\end{array}$ & $\begin{array}{c}\text { Soriun, } \\
\text { OIS- } \\
\text { SOLVE } \\
(\cdot 1, / L\end{array}$ & $\begin{array}{c}\text { SOIIUM } \\
\text { A.I- } \\
\text { SUNP- } \\
\text { TION } \\
\text { WAIIO }\end{array}$ & soniun. & 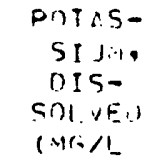 \\
\hline DATE & A5 PI & AS FI & $(4(03)$ & $(A C \cap 3)$ & as $(A)$ & AS M(B) & $A S|A|$ & & DEKCE , $T$ & $A S<1$ \\
\hline $\begin{array}{l}\text { JAN } \\
12 \ldots \\
\text { MAR }\end{array}$ & 179.090 & $\cdots$ & 500 & 0 & $9 \pi$ & 63 & 72 & 1.4 & 23 & 9.1 \\
\hline $\begin{array}{l}27 \ldots \\
\text { JUiv }\end{array}$ & .010 & .00 & 230 & 53 & 52 & 25 & 33 & .4 & 2.3 & $3 . v$ \\
\hline $\begin{array}{l}13 \ldots \\
\mathrm{OCT} \\
02 .\end{array}$ & $-\infty$ & $=-$ & - & $-\infty$ & -- & $-\infty$ & $-\infty$ & $-\infty$ & $-\infty$ & - \\
\hline & $\begin{array}{l}\text { CHLOE } \\
\text { PIDE. } \\
\text { UIS- } \\
\text { SOLVEO } \\
\text { CMCOLL }\end{array}$ & $\begin{array}{l}\text { SULLATE } \\
\text { OISS- } \\
\text { SOLVEI) } \\
\text { (MSOL }\end{array}$ & $\begin{array}{l}\text { FLUO- } \\
\text { PINF, } \\
\text { OIS- } \\
\text { SOLVEN } \\
1.16 / L\end{array}$ & $\begin{array}{l}\text { SILICA. } \\
\text { DISE } \\
\text { SOLVEN } \\
\text { I.AG/L } \\
\text { AS }\end{array}$ & $\begin{array}{c}\text { ARSF -jIC } \\
\text { IIS- } \\
\text { SOL.JEU } \\
1 U ; / L\end{array}$ & $\begin{array}{l}\text { 31)RON! } \\
\text { IIS- } \\
\text { SOLVEU } \\
\text { (UG/L }\end{array}$ & $\begin{array}{c}\text { CAD:ALUA } \\
\text { DIS- } \\
\text { SULVEA } \\
\text { (IIG/L }\end{array}$ & $\begin{array}{l}C H: X]- \\
H I U i-1, \\
\text { JIS- } \\
\text { SULVES) } \\
(1)(6 / L\end{array}$ & $\begin{array}{l}\text { CUUPED, } \\
\text { UIS- } \\
\text { SULV=i1 } \\
\text { l1IGA. }\end{array}$ & 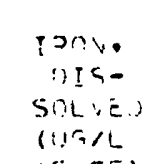 \\
\hline i) ATE & $\Delta S C L)$ & 15 $50+1$ & $\Delta S F I$ & Sโ0Z1 & AS ISI & AS BI & $\Delta S(i)$ & $A S(Q)$ & AS $C(1)$ & $\left.\Delta S \quad F F_{.}\right)$ \\
\hline $\begin{array}{l}\text { JAN } \\
\begin{array}{c}12 . . \\
\text { MAR }\end{array}\end{array}$ & 179 & 87 & .5 & 23 & 1 & 4700 & $<1$ & 0 & 8 & 40 \\
\hline$\underset{J U^{\prime N}}{27} \cdots$ & 16 & 36 & .6 & 16 & -- & 2500 & -- & 0 & - & 230 \\
\hline${ }_{\mathrm{OCT}}^{13} \ldots$ & -- & -- & - & -- & -- & 300 & $\ldots$ & - & $-\infty$ & 10 \\
\hline $02 \ldots$ & -- & -- & $-\infty$ & -- & -- & 3300 & $-\infty$ & 10 & $-\infty$ & - \\
\hline & $\begin{array}{l}\text { LEAN, } \\
\text { JIS- } \\
\text { SULVEO } \\
\text { IJU/L }\end{array}$ & $\begin{array}{l}\text { MANGA- } \\
\text { NESE: } \\
\text { NIS- } \\
\text { SOLVEI) } \\
(I I G / L\end{array}$ & $\begin{array}{l}\text { VICKEL } \\
\text { OIS- } \\
\text { SCI VE, } \\
\text { (UI, }\end{array}$ & $\begin{array}{l}\text { RYV. } \\
\text { iIG- } \\
\text { SกLVFO } \\
(11 G / L\end{array}$ & 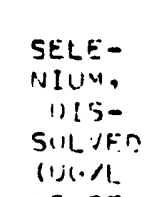 & $\begin{array}{l}\text { SFLE- } \\
\text { VIINA. } \\
\text { SUS- } \\
\text { PF VDE } \\
\text { TOTAL } \\
\text { IUIJ/L }\end{array}$ & 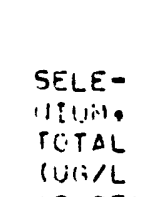 & 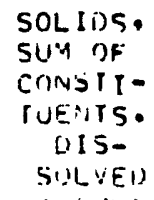 & $\begin{array}{c}\text { SULIDS. } \\
\text { OIS- } \\
\text { SULVF') } \\
\text { (TINAS } \\
\text { DER }\end{array}$ & 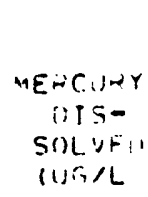 \\
\hline NATE & AS D.31 & IS mivs & $\Delta G N(T)$ & AS 201 & AS SEI & $\triangle S S E I$ & AS SEI & $(\omega G / 1)$. & $A C-F()$ & AS \\
\hline
\end{tabular}

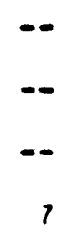

$13 .$.

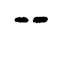

UCF

1) $2 \ldots$
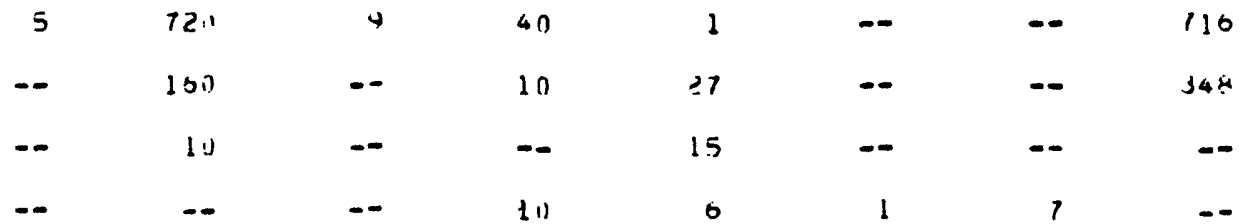
WATER-QUALITY DATA FOR WELL HS-17, HAYDEN POWERPLANT, HAYDEN, COLO.

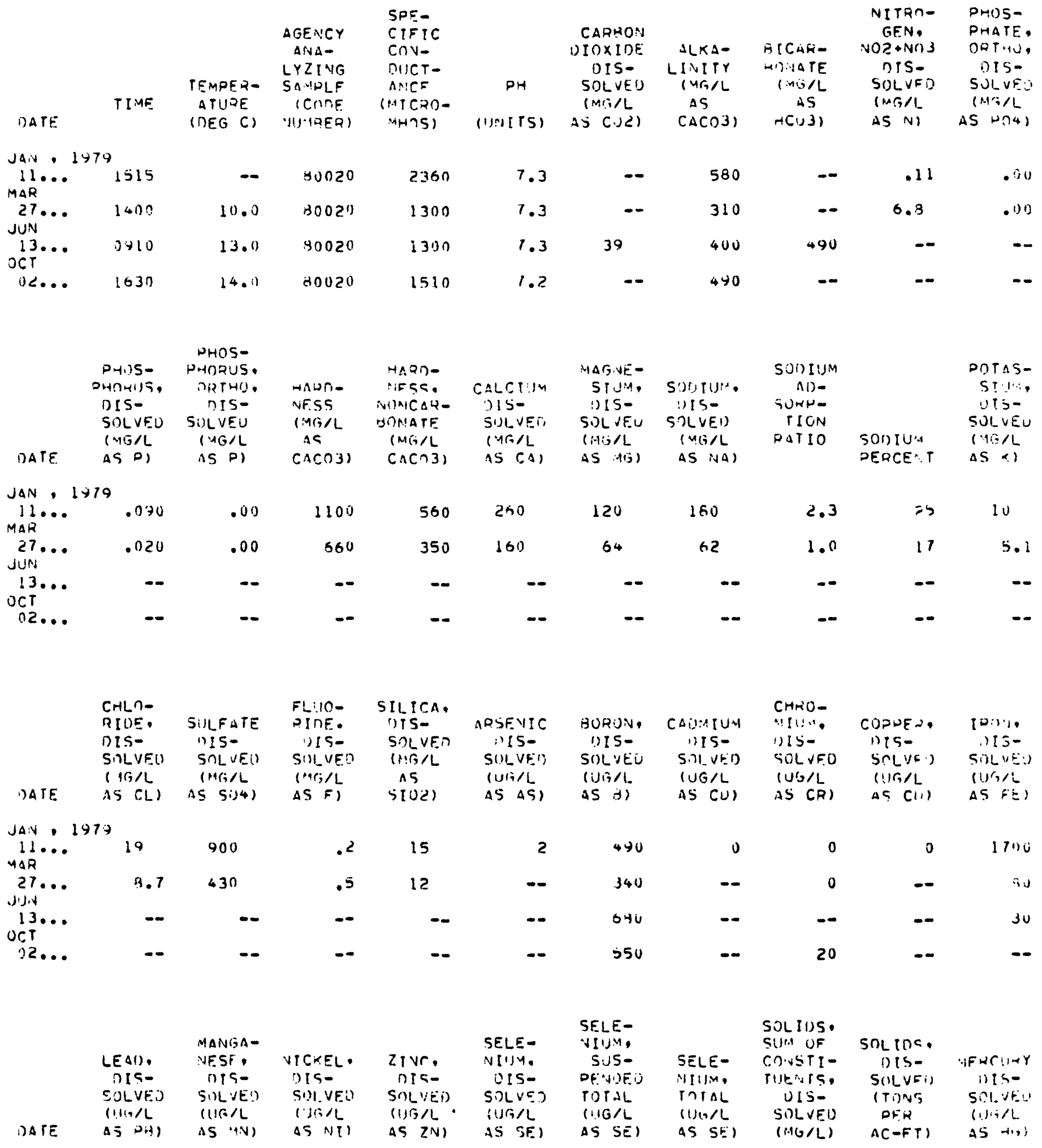


WATER-QOALITY DATA FOR WELL HS-18, HAYDEN POWERPLANT, HAYDEN, COLO.

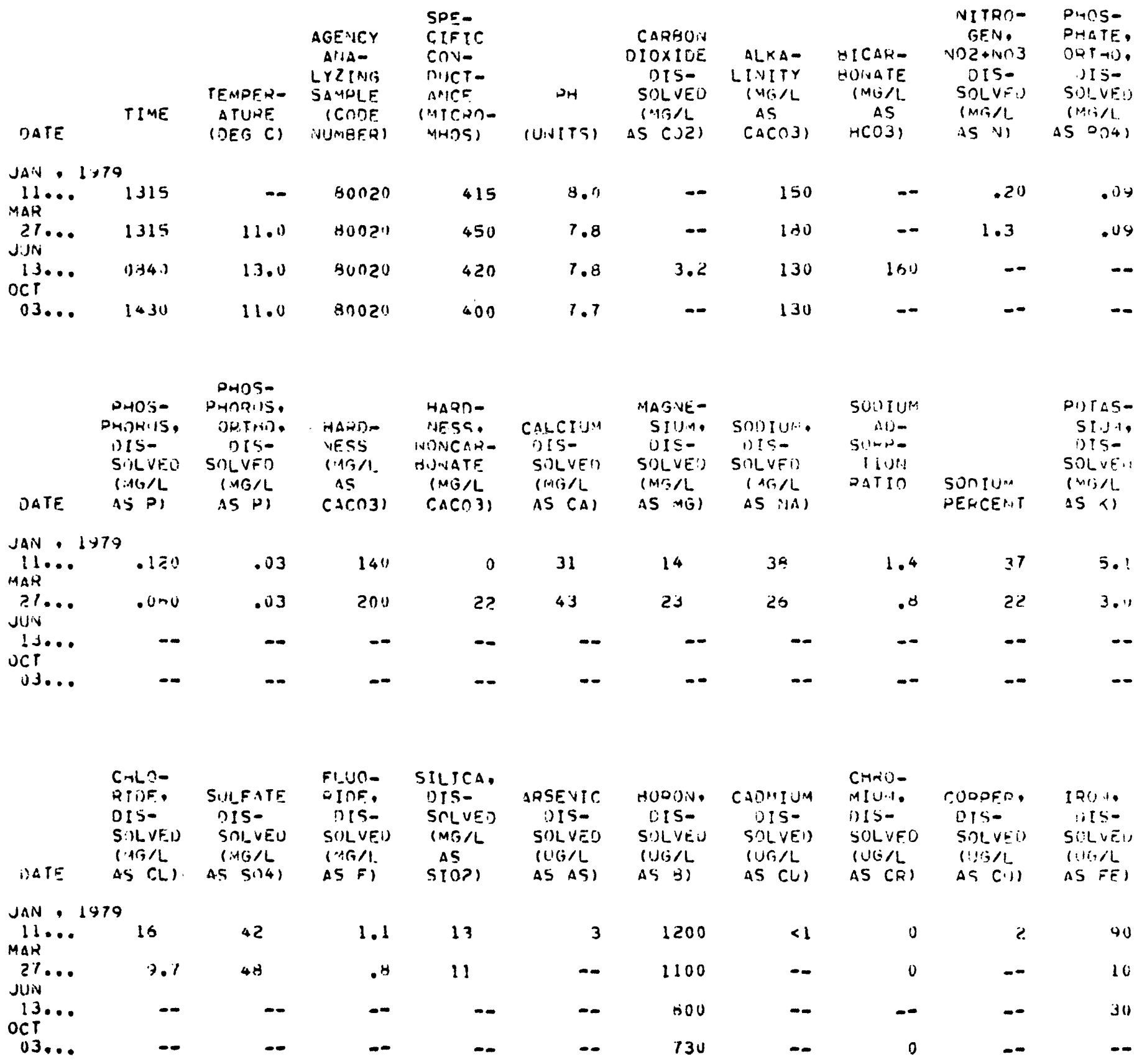

\begin{tabular}{|c|c|c|c|c|c|c|c|c|c|c|}
\hline DATE & $\begin{array}{l}\text { LEND, } \\
D(S- \\
\text { SกLVEO } \\
(: J(G / L \\
\text { AS } D: 1)\end{array}$ & $\begin{array}{l}\text { MANRA- } \\
\text { NESE. } \\
\text { DIS- } \\
\text { S.)LVEO } \\
\text { (UG/L } \\
\text { AS W(W) }\end{array}$ & $\begin{array}{l}\text { NICKELL } \\
\text { OIS- } \\
\text { SIULVE) } \\
\text { (US:L } \\
\text { AS NII }\end{array}$ & $\begin{array}{l}\text { LTVE, } \\
\text { OIS- } \\
\text { SOLVEN } \\
\text { (IIC/L } \\
\text { AS ZV) }\end{array}$ & $\begin{array}{l}\text { SELE- } \\
\text { A IUIA. } \\
\text { OISS- } \\
\text { SILLVEO } \\
\text { (UG/L } \\
\triangle S \text { SE.) }\end{array}$ & $\begin{array}{l}\text { SELE- } \\
\text { NIUM, } \\
\text { SUS- } \\
\text { PEIIIEU } \\
\text { TOTAL } \\
\text { (UG/L } \\
\text { AS SE.) }\end{array}$ & $\begin{array}{l}\text { SELE- } \\
\text { HIUHA-A } \\
\text { TOTAL } \\
\text { (UG/L } \\
\text { AS SE) }\end{array}$ & $\begin{array}{l}\text { SULIUS, } \\
\text { SUIA UF } \\
\text { CUIIII- } \\
\text { TUE ITS, } \\
\text { UIS- } \\
\text { SULVEU } \\
\text { (ALOLI) }\end{array}$ & $\begin{array}{c}\text { SOLIDS- } \\
\text { OIS- } \\
\text { SOLVEI) } \\
\text { (TONS } \\
\text { PER } \\
\text { AC-FT) }\end{array}$ & $\begin{array}{c}\text { WERCJNY } \\
\text { DIS- } \\
\text { SOLVEU } \\
\text { (UGLL } \\
\text { AS MII) }\end{array}$ \\
\hline JAn & & & & & & & & & & \\
\hline $11 \ldots$ & $\theta$ & 500 & 5 & 10 & 2 & - & - & 253 & .34 & .11 \\
\hline $27 \cdots$ & - & ) & -- & 10 & h & $\ldots$ & - & 280 & .78 & $-\infty$ \\
\hline${ }_{a C}^{13} \cdots$ & - & $:+1)$ & - & -- & 3 & $-\infty$ & -- & - & - & - \\
\hline $03 \ldots$ & $\cdots$ & - & - & 0 & 3 & v & 3 & -- & - & - \\
\hline
\end{tabular}


WATER-QUALITY DATA FOR WELL EC-1, HAYDEN POWERPLANT, HAYDEN, COLO.

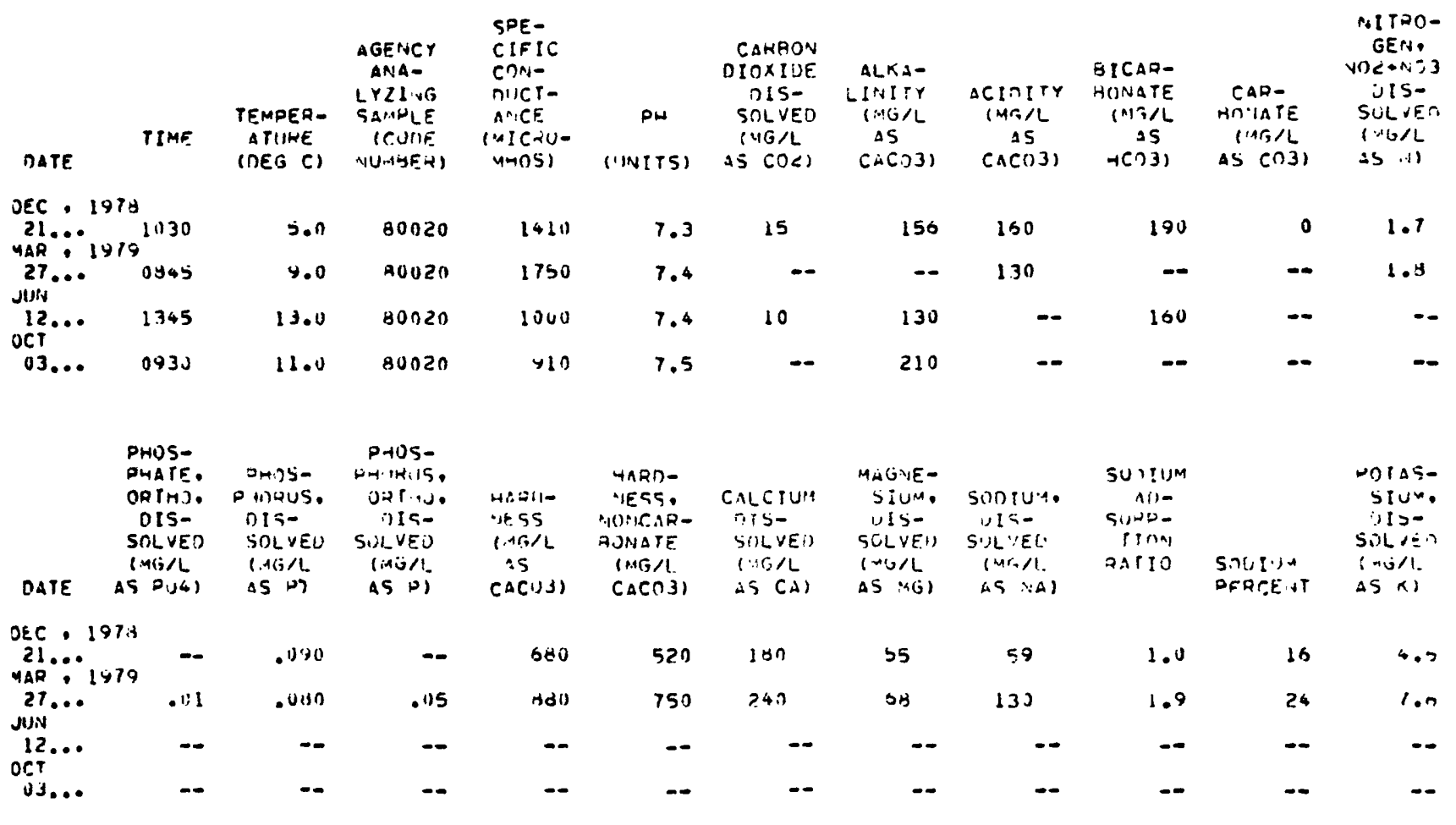

\begin{tabular}{|c|c|c|c|c|c|c|c|c|c|c|}
\hline & $\begin{array}{l}\text { CHLON- } \\
R[\text { IDE, } \\
\text { OIS- } \\
\text { SNLVFI) } \\
\text { (ATSL }\end{array}$ & $\begin{array}{l}\text { SILFATF. } \\
\text { IISS- } \\
\text { SULVEIT } \\
\text { IMTSLL }\end{array}$ & 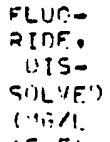 & 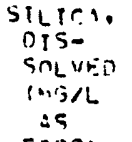 & $\begin{array}{l}\text { ADSE UTC } \\
\text { UIS- } \\
\text { SOLVFI) } \\
\text { (UUAL }\end{array}$ & $\begin{array}{l}\text { HOWIIN, } \\
\text { JIS- } \\
\text { SILVEL } \\
\text { (ULi,L }\end{array}$ & 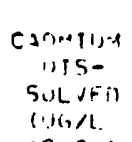 & 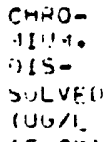 & $\begin{array}{l}\text { CUDSEO. } \\
\text { OIS- } \\
\text { SOLVEI) } \\
(1,1) .\end{array}$ & 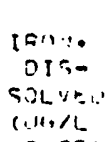 \\
\hline IE & AS (L) & $\Delta S$ SOA) & $45 \mathrm{Fi}$ & $5(02)$ & $\triangle S$ ASI & as a) & AS Cul & AS (i) & 25 (ii) & AS $=E$ : \\
\hline
\end{tabular}

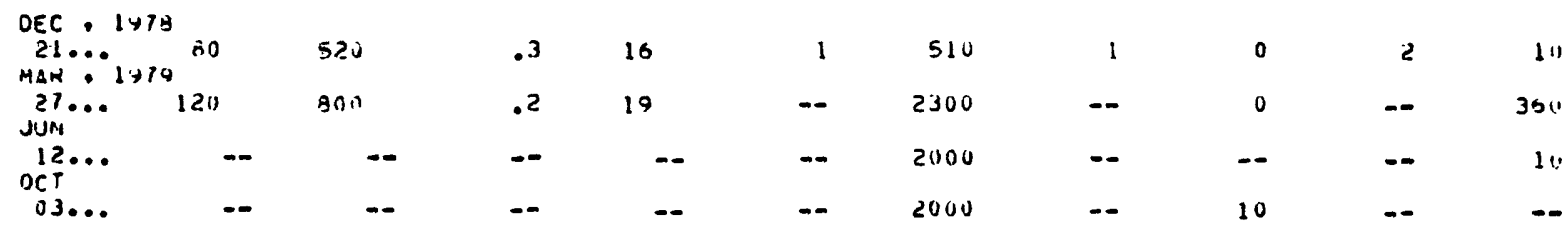

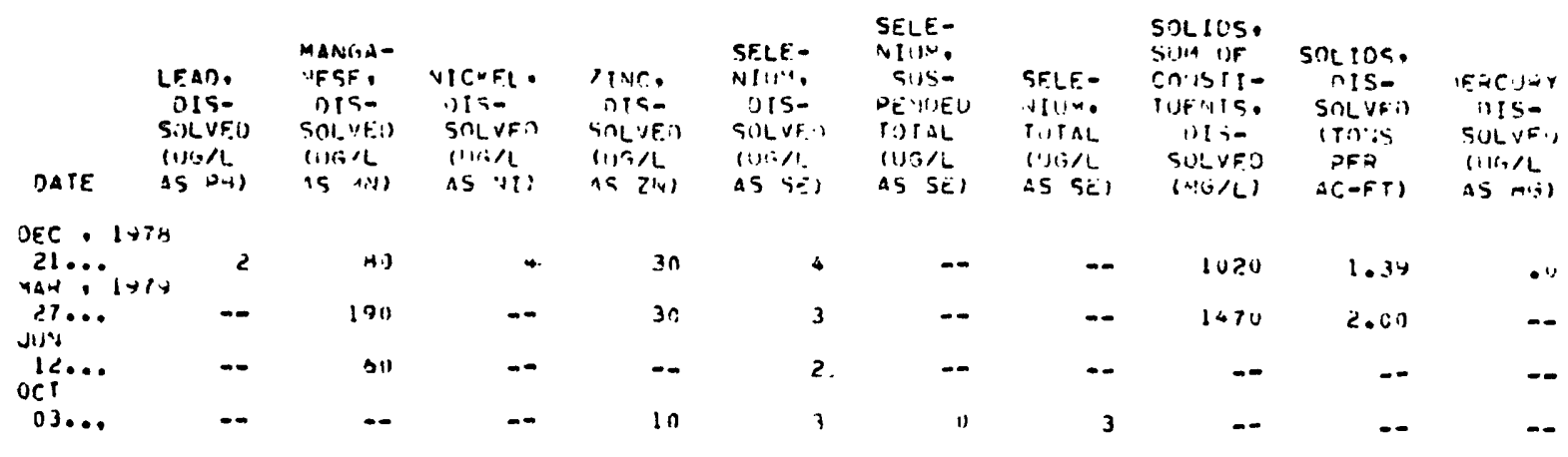


WATER-QUALITY DATA FOR WELL EC-2, HAYDEN POWERPLANT, HAYDEN, COLO.

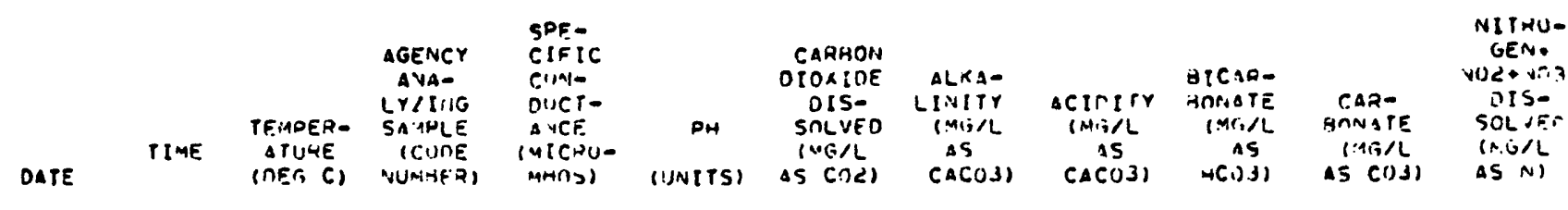
OEC, 1479

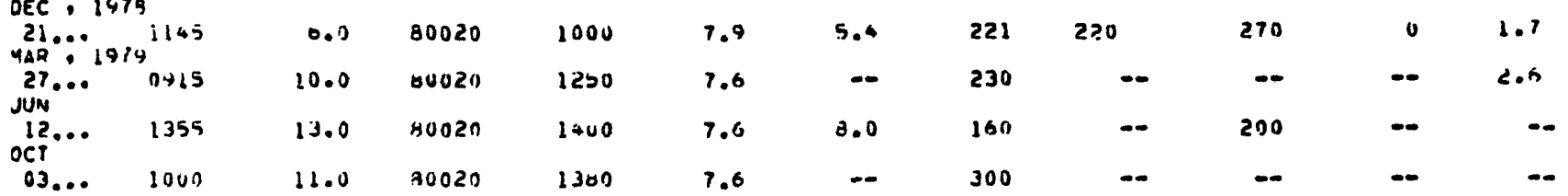

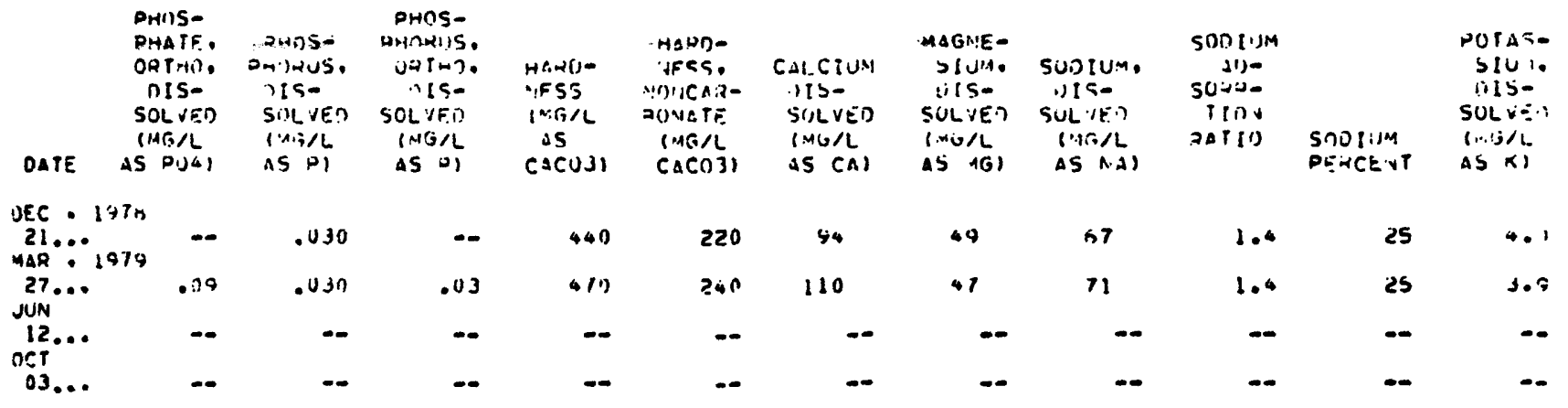

\begin{tabular}{|c|c|c|c|c|c|c|c|c|c|c|}
\hline DATE & $\begin{array}{l}\text { CHLO- } \\
\text { PIDE, } \\
\text { OIS- } \\
\text { SNLVED } \\
\text { ('EL/L } \\
\text { AS CL) }\end{array}$ & $\begin{array}{l}\text { SIJlFATF. } \\
\text { JIS- } \\
\text { SOLVE? } \\
\text { (HISAL } \\
\text { AS SUA) }\end{array}$ & 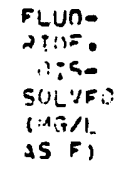 & 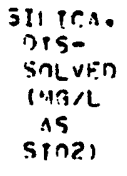 & $\begin{array}{l}\text { ADSE.JTC } \\
\text { UIS- } \\
\text { SULVFn } \\
\text { (WOLL } \\
\text { AS AS) }\end{array}$ & 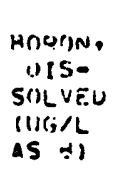 & 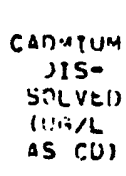 & 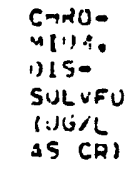 & $\begin{array}{l}\text { COPDED. } \\
\text { U[S- } \\
\text { S(1'VE) } \\
\text { (11(i/l. } \\
\text { AS CIJ) }\end{array}$ & 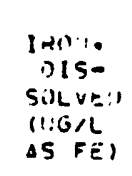 \\
\hline \multicolumn{2}{|c|}{ 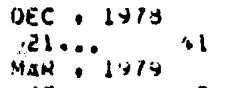 } & 310 & .3 & 17 & 1 & 1.100 & 2 & $\dot{v}$ & 4 & 10 \\
\hline JiNN & 49 & 330 & .8 & 17 & $-\infty$ & 1400 & - & 0 & $\rightarrow$ & 3v \\
\hline $12 \ldots$ & -- & -- & $\cdots$ & - & $\cdots$ & 1900 & $\infty$ & - & $\cdots$ & 10 \\
\hline $03 .$. & $\cdots$ & $\cdots$ & $-\infty$ & $\cdots$ & $-\infty$ & 1500 & -- & 0 & - & $\cdots$ \\
\hline nITE & $\begin{array}{l}\text { LEAn, } \\
\text { iIIS- } \\
\text { S.)LVE:1) } \\
(1)(3 / 1 \\
\text { AS } 2+1)\end{array}$ & 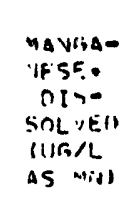 & 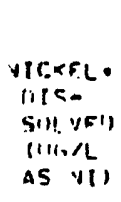 & 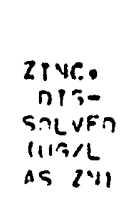 & 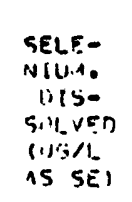 & 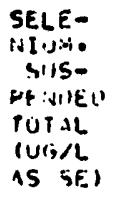 & $\begin{array}{l}\text { SFLE- } \\
\text { NIUMA } \\
\text { PITTAL } \\
\text { (U'ARL } \\
\text { AS SE) }\end{array}$ & $\begin{array}{l}\text { SUL IUS, } \\
\text { SUM iIF } \\
\text { CIUSTI- } \\
\text { PUE'SIS. } \\
\text { IJIS- } \\
\text { SOLVEO } \\
\text { IVISLI) }\end{array}$ & $\begin{array}{c}\text { SOLINS. } \\
\text { nIS- } \\
\text { SCI.VEO } \\
\text { IT NIS } \\
\text { NER } \\
\text { AC-FTI }\end{array}$ & $\begin{array}{l}\text { "FRC JWY } \\
\text { WIS- } \\
\text { SOLVFil } \\
\text { (URAL } \\
\text { AS ti) }\end{array}$ \\
\hline $\begin{array}{l}\text { DEC } \\
21 \ldots \\
\text { पsH }\end{array}$ & 7月 & 00 & 5 & 20 & 7 & -- & $-\infty$ & 725 & .119 & $\bullet$ \\
\hline •יטנינ? & $\cdots$ & 61) & $\cdots$ & 10 & 7 & $\cdots$ & $\cdots$ & 179 & 1..16 & $\cdots$ \\
\hline${ }_{\text {vel }}^{12 \ldots}$ & $\cdots$ & 111 & $-\infty$ & -- & 4 & $-\infty$ & $\cdots$ & $\cdots$ & $\cdots$ & -- \\
\hline 133.0 & $\cdots$ & $\cdots$ & -- & (1) & 4 & v & 4 & $\cdots$ & $\infty$ & $\cdots$ \\
\hline
\end{tabular}


WATER-QUALITY DATA FOR WELL FC-3, HAYDEN POWERPLANT, RAYDEN, COLO.

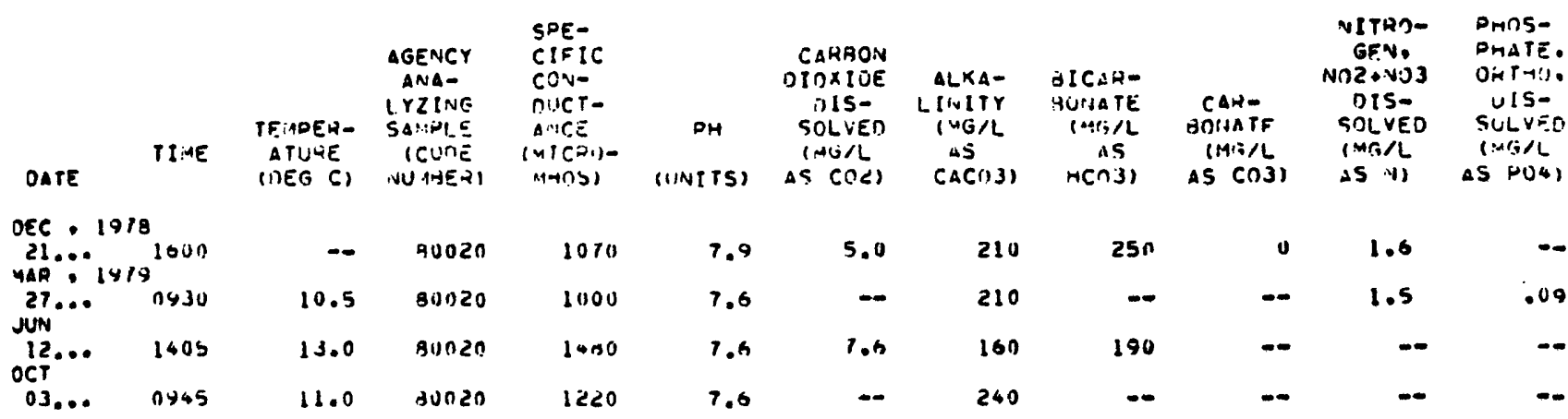
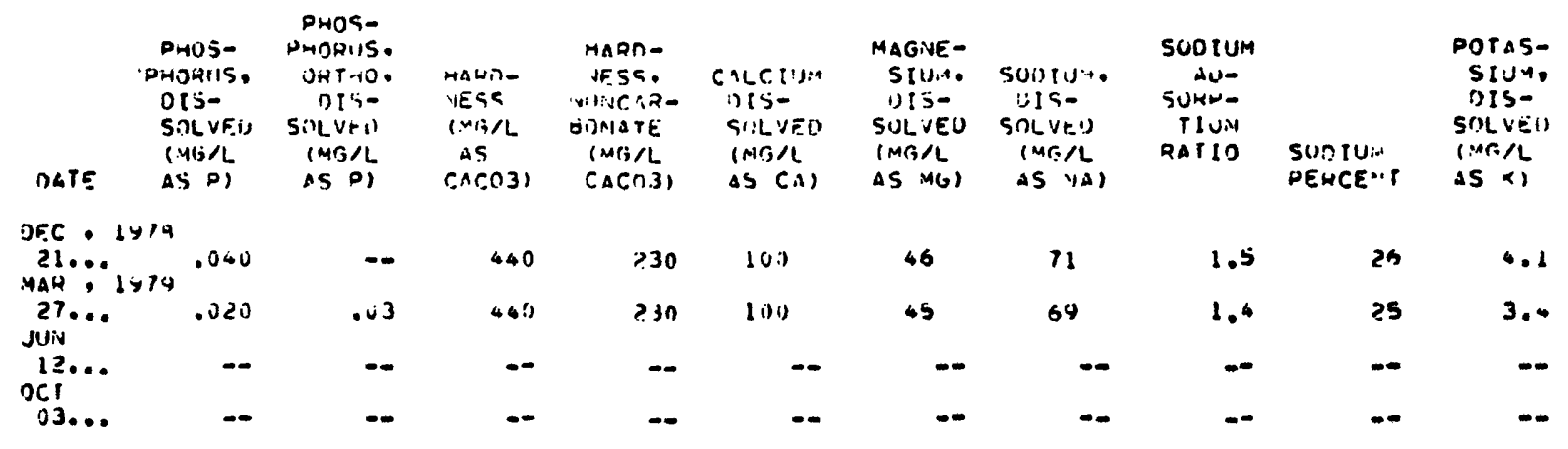

(1)

$$
\text { CACn.3) as (A) }
$$

$$
\text { as ing) as vid }
$$

PEHCE + P

a $<1$

$\begin{array}{rrr}440 & 3.30 & 100 \\ 440) & ? 3 n & 100 \\ - & \ldots & \ldots \\ - & \ldots & \ldots\end{array}$

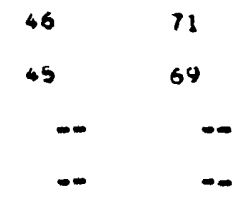

\section{5}

$26 \quad 4.1$

1.4

25

3.0

$+$

25

$-\infty$

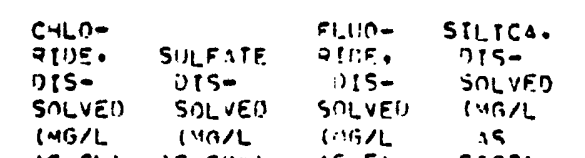

argevic

1) IS-
SULVFก

HORON.

DIS-

STLVEV

(uis)

AS A 51

AS मो

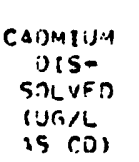

(MNA) -

MIJM, CIJOOED, IUN:!

UIS- DIS- DIS-

SISLVE SOLVFI) SRI."EI

(UG/L IURAI (1)TIL

\begin{tabular}{|c|c|c|c|c|c|c|}
\hline $\operatorname{MAR}, 1+19$ & 45 & 320 & .6 & 16 & 1 & 1000 \\
\hline JUiv $27 . .$. & 44 & 290 & .7 & 16 & - & 1800 \\
\hline ocT $12 \ldots$ & - & $-\infty$ & -- & - & -- & 1700 \\
\hline 03. & - & $\infty$ & $-\infty$ & - & - & 1000 \\
\hline
\end{tabular}

DATE AS

aS (R)

As (II)

AS FE.
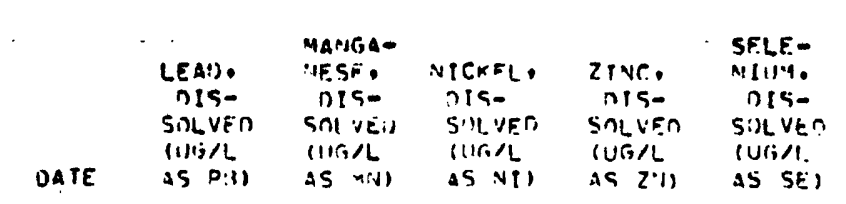

SELE-

5.15-

DENDEI

TOTAL

(UIJ/L

AS SE)

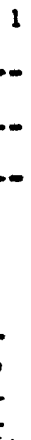

(1)

SOL Ii)S.

Su'd of

S(x) II)s.

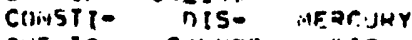

TUE'VIS.

UIS-

SOLVEO

Sil $V=0$

(T) DWS IS-

lid

AS SE)

(YU/L)

\begin{tabular}{|c|c|c|c|c|}
\hline $\begin{array}{rl}21 & 1\end{array}$ & 4 & רו9? & 5 & $3 n$ \\
\hline Juit $27 \ldots$ & $-\infty$ & 40 & $-\infty$ & 10 \\
\hline${ }_{121}$ & $-\infty$ & v & - & $\infty$ \\
\hline . . & $-\infty$ & - & $-\infty$ & 10 \\
\hline
\end{tabular}

AC-FT) AS A(j) 
WATER-QUALITY DATA FOR WELL FC-4, RAYDEN POWERPLANT, HAYDEN, COLO.

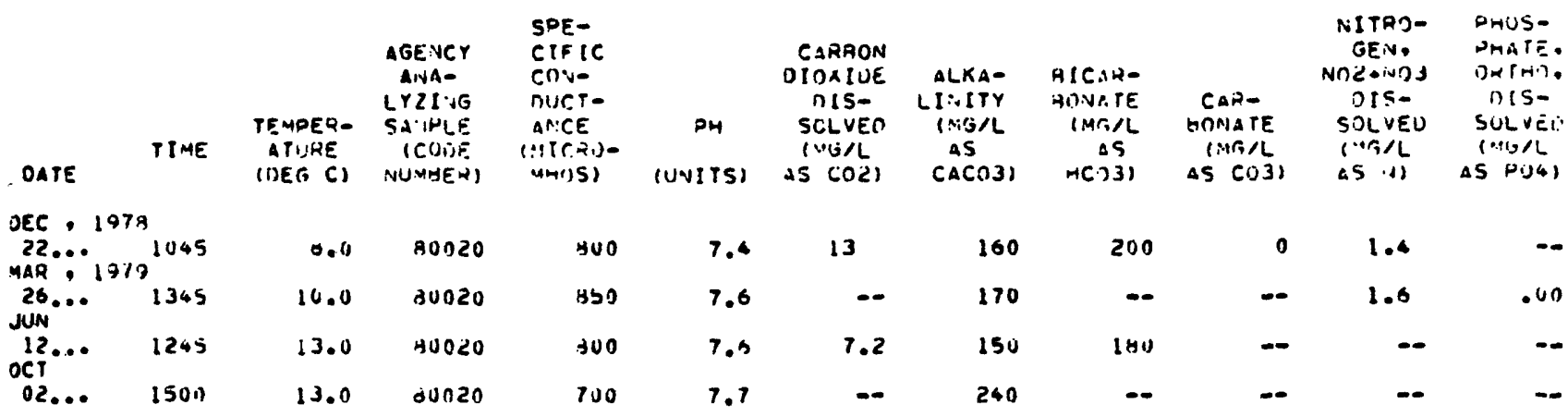

\begin{tabular}{|c|c|c|c|c|c|c|c|c|c|c|}
\hline DATE & $\begin{array}{l}\text { PHOS- } \\
\text { P-1.)HISS. } \\
\text { OIS- } \\
\text { SULVES } \\
\text { IWLLL } \\
\text { AS DI }\end{array}$ & 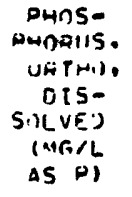 & $\begin{array}{l}\text { rasn- } \\
\text { NESSS } \\
\text { (UR:AL } \\
\text { AS } \\
\text { CACOB) }\end{array}$ & 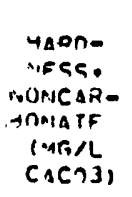 & $\begin{array}{l}\text { CALCIUM } \\
\text { OIS- } \\
\text { SUL }+L) \\
\text { (MGSL } \\
\text { AS CA) }\end{array}$ & $\begin{array}{l}\text { MAGPIE- } \\
\text { SI:JM. } \\
\text { JIS- } \\
\text { SOLVEL } \\
\text { ( IS/LL } \\
\text { AS "AG) }\end{array}$ & 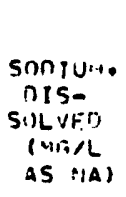 & 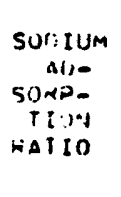 & $\begin{array}{l}\text { SOEIUN" } \\
\text { PEHCE IT }\end{array}$ & $\begin{array}{l}\text { POTAS- } \\
\text { St:1:A, } \\
\text { DIS- } \\
\text { SnLVei) } \\
\text { (Yi, } \\
\text { AS K) }\end{array}$ \\
\hline $\begin{array}{l}\text { OFC. } \\
22 .: \\
\text { RAP?: }\end{array}$ & $\begin{array}{l}\rightarrow 78 \\
y 79\end{array}$ & $\ldots$ & 360 & 200 & ist & 35 & 50 & 1.1 & ? & 4 \\
\hline$\underset{\text { JIN }}{26.0}$ & .020 & .00 & 380 & ?.1n & 92 & 36 & 50 & 1.1 & 22 & 5.11 \\
\hline${ }_{\text {ocr }}^{12 .}$ & - & -- & -- & - & -- & $-\infty$ & - & $-\infty$ & - & $\cdots$ \\
\hline $02 \ldots$ & - & $\cdots$ & - & - & $\cdots$ & -- & - & $-\infty$ & -- & $\cdots$ \\
\hline
\end{tabular}

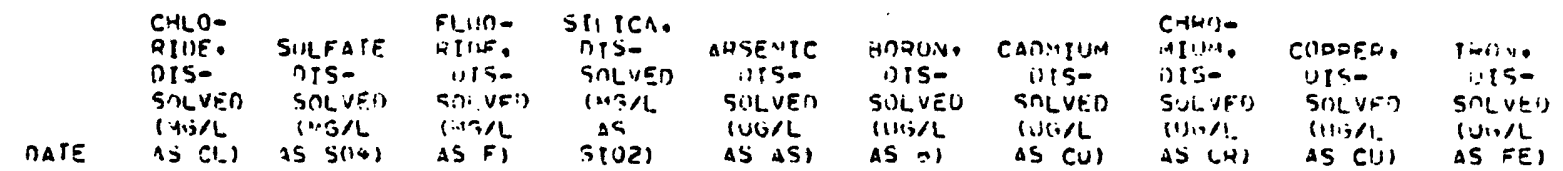

OF.C. 2978

\begin{tabular}{|c|c|c|c|c|c|c|c|c|c|c|}
\hline $\begin{array}{l}\text { OFC. } 1978 \\
\text { MAR } 22 . \cdots 1970\end{array}$ & 45 & 230 & 1.0 & 14 & 1 & 440 & 1 & 0 & 3 & 0 \\
\hline JUN $26 . .$. & 41 & 230 & $1 . n$ & 14 & - & 2300 & $\ldots$ & 0 & $\ldots$ & 40 \\
\hline${ }_{\text {OCT }}^{12} \cdots$ & - & $\cdots$ & - & $\cdots$ & $-\infty$ & 220 & - & - & $\cdots$ & 10 \\
\hline 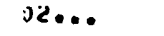 & $\cdots$ & $\cdots$ & $\cdots$ & $\cdots$ & - & 1900 & $-\infty$ & 0 & - & - \\
\hline
\end{tabular}

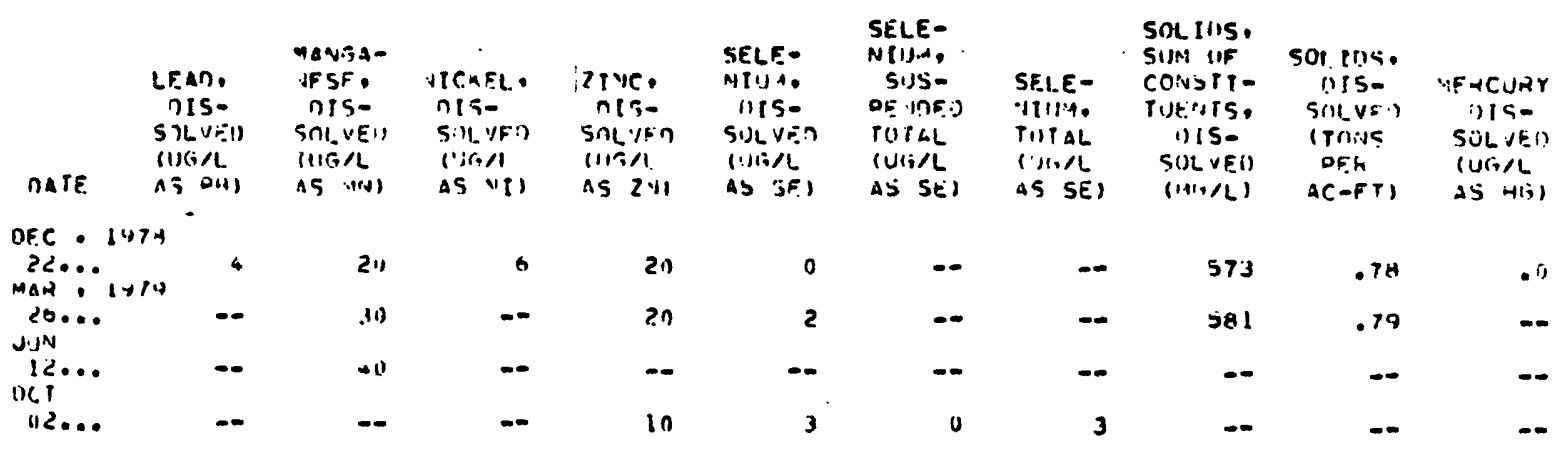


WATER-QUALITY DATA EOR HS SEEP 1, HAYDEN POWERPLALT, HAYDEN, COLO.

\begin{tabular}{|c|c|c|c|c|c|c|c|c|c|c|c|}
\hline OATE & TIME & $\begin{array}{l}\text { TEMPER- } \\
\text { ATUKE } \\
\text { (DEG C) }\end{array}$ & 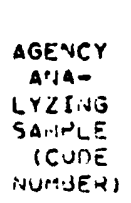 & 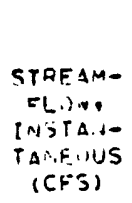 & $\begin{array}{l}\text { SPF- } \\
\text { CIFIC } \\
\text { CNI- } \\
\text { DCT- } \\
\text { AVCF } \\
\text { (-TICPO- } \\
\text { AHOS) }\end{array}$ & $\begin{array}{c}P H \\
\text { (II:NITS) }\end{array}$ & $\begin{array}{l}\text { CARIRON } \\
\text { DIUXIDE } \\
\text { DIS- } \\
\text { SULVED } \\
\text { (1+FI/L } \\
\text { AS CJZ) }\end{array}$ & $\begin{array}{l}\text { ALKA- } \\
\text { LNYTY } \\
\text { (MTAL } \\
\text { AS } \\
\text { CACO3) }\end{array}$ & $\begin{array}{c}\text { HICAY- } \\
\text { BOVATE } \\
\text { IMTALL } \\
\text { AS } \\
\text { HCOß) }\end{array}$ & 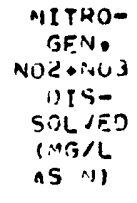 & 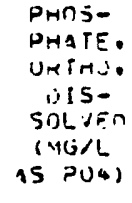 \\
\hline \multicolumn{12}{|c|}{ JAN $\cdot 1979$} \\
\hline & 1520 & 6.0 & 80020 & E. 10 & 1040 & 8.0 & -- & 150 & - & .91 & .06 \\
\hline $\begin{array}{l}\text { Jun } \\
13 \ldots . . . \\
\text { oCt }\end{array}$ & 1010 & 14.0 & 90020 & $\langle .01$ & 650 & 8.3 & 1.1 & 170 & 210 & $-\infty$ & - \\
\hline $03 . \ldots$ & 1445 & $12.1)$ & 40020 & E.ul & 550 & 7.5 & -- & 170 & -- & $\cdots$ & -- \\
\hline & $\begin{array}{l}\text { PHUS- } \\
\text { PrDWiUS. } \\
\text { OIS- } \\
\text { SNL VEI) } \\
\text { (MG/L }\end{array}$ & $\begin{array}{l}\text { OHIIS- } \\
\text { PUORUS. } \\
\text { ITTMU. } \\
\text { OISS- } \\
\text { SOLVES } \\
\text { IMRLL }\end{array}$ & $\begin{array}{l}\text { HCHII- } \\
\text { YESA } \\
\text { 1.16/L } \\
\text { AS }\end{array}$ & 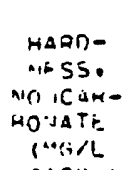 & $\begin{array}{l}\text { CALCIJA } \\
\text { OIS- } \\
\text { SOLVFO } \\
\text { IMCOL }\end{array}$ & $\begin{array}{l}\text { MAGNE- } \\
\text { SIUV. } \\
\text { IIS- } \\
\text { SOLVET } \\
\text { IAG/L }\end{array}$ & $\begin{array}{l}\text { SUULUA, } \\
\text { ')IS- } \\
\text { SULVED } \\
1: 1, / L\end{array}$ & 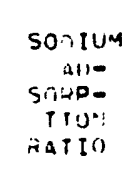 & Soviu' & $\begin{array}{l}\text { DOTAS- } \\
\text { SIUII, } \\
\text { JIS- } \\
\text { SHEVED } \\
\text { IHAL }\end{array}$ & 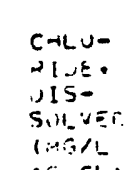 \\
\hline ATE & $45 \mathrm{N1}$ & is $\mathrm{w}$ & CaCu3) & (AC:S) & AS $(\Delta)$ & $15 \quad 1(j)$ & $A S$ IAI & & HERCENT & $A S<1$ & $\triangle S C L I$ \\
\hline
\end{tabular}

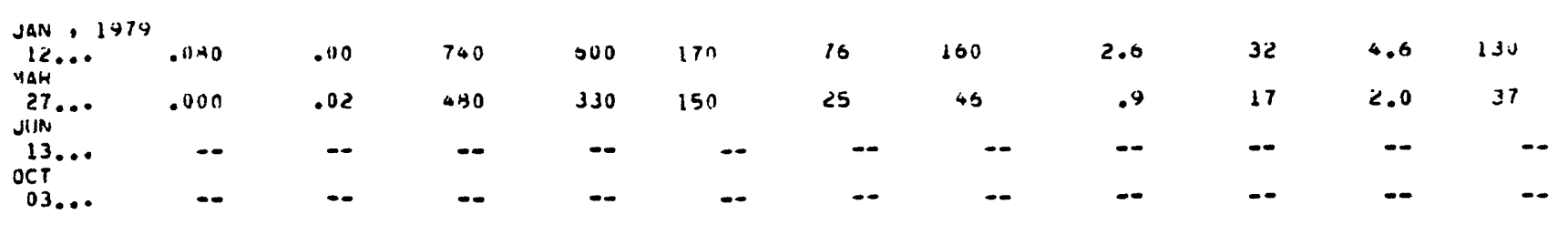

\begin{tabular}{|c|c|c|c|c|c|c|c|c|c|c|}
\hline & $\begin{array}{l}\text { SULFATE } \\
\text { OIS- } \\
\text { SnLVE. } \\
1: 11 ; / L\end{array}$ & 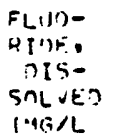 & 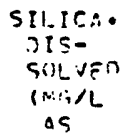 & $\begin{array}{c}\text { AHE=UIC } \\
\text { nISE } \\
\text { SNLVEN } \\
\text { IIG/I. }\end{array}$ & $\begin{array}{l}\text { quAn: } \\
\text { UlS- } \\
\text { SULVFn } \\
\text { (11) }\end{array}$ & $\begin{array}{c}\text { CAOAIUY } \\
\text { iJISO } \\
\text { SILVEU } \\
\text { (U);/L }\end{array}$ & 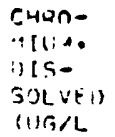 & $\begin{array}{l}\text { CIPNER. } \\
\text { iIIS- } \\
\text { SULVFU } \\
\text { (INU/1. }\end{array}$ & 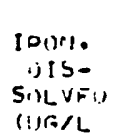 & 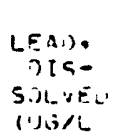 \\
\hline DATE & AS Sin 41 & $\Delta S$ FI & $5 ! 02)$ & $\Delta S \Delta S)$ & A. $5 \mathrm{HI}$ & AS (I) & $\Delta S(2)$ & as (U) & AS FF) & AS $2 n 1$ \\
\hline
\end{tabular}

\begin{tabular}{|c|c|c|c|c|c|c|c|c|c|c|}
\hline $\begin{array}{l}12 \\
42 R\end{array}$ & 130 & .7 & 14 & 1 & 1200 & 4 & 0 & 4 & 60 & $s$ \\
\hline$\underset{\text { JuN }}{27} \cdots$ & 310 & .0 & 9.4 & - & 1700 & $-\infty$ & 0 & $-\infty$ & 10 & - \\
\hline${ }_{\text {OCT }}^{13} \cdots$ & $\cdots$ & $-\infty$ & -- & - & $12 i 10$ & $-\infty$ & - & $-\infty$ & 240 & - \\
\hline 03... & $=$ & $-\infty$ & $-\infty$ & - & 1100 & - & 10 & $-\infty$ & $-\infty$ & -- \\
\hline
\end{tabular}

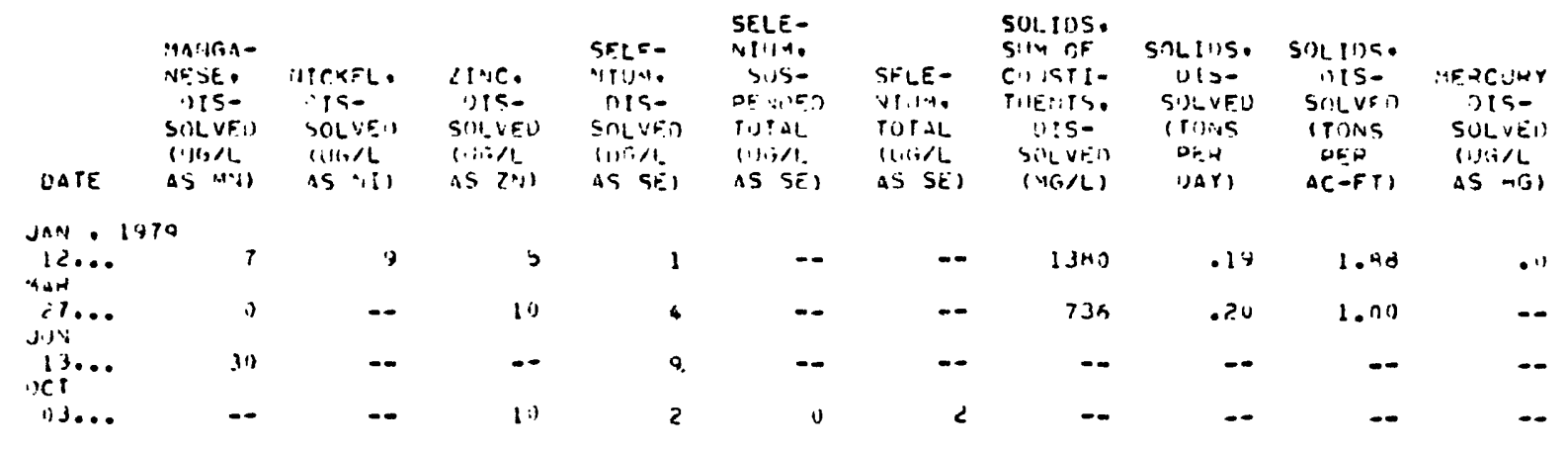


WATER-QUALITY DATA FOR AS SEEP 2, HAYDEN POWERPLANT, HAYDEN, COLO.

\begin{tabular}{|c|c|c|c|c|c|c|c|c|c|c|c|}
\hline DATE & TIME & $\begin{array}{l}\text { TEMPEP- } \\
\text { DTUHE } \\
\text { (I)E(; C) }\end{array}$ & 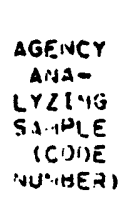 & 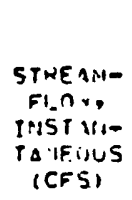 & $\begin{array}{l}\text { SDE- } \\
\text { CIFIC } \\
\text { CNH- } \\
\text { OUCT- } \\
\text { ANCE } \\
\text { (UICKN- } \\
\text { MHOS) }\end{array}$ & $\begin{array}{c}P H \\
(1 ! \cdot 1) \text { TS }\end{array}$ & $\begin{array}{c}\text { CARROII } \\
\text { OIOXIDE } \\
\text { UISE } \\
\text { SOLVEN } \\
\text { (M:I/L } \\
\text { AS C:JLI }\end{array}$ & $\begin{array}{l}\text { ALrA- } \\
\text { LINITY } \\
\text { (WT/L } \\
\text { AS } \\
\text { CACD 3) }\end{array}$ & $\begin{array}{c}\text { AICAR- } \\
\text { HITATE } \\
\text { (MrAL } \\
\text { AS } \\
\text { HCOJ) }\end{array}$ & $\begin{array}{c}\text { "ITRN- } \\
\text { GFN. } \\
\text { MNR+NO3 } \\
\text { OIS- } \\
\text { SILVED } \\
\text { (ME/L } \\
\text { AS NII }\end{array}$ & 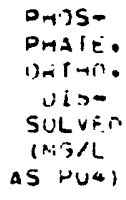 \\
\hline JAN - & 9 & & & & & & & & & 51 & n? \\
\hline WAH & $111<0$ & 0.0 & $200<0$ & 80 & 900 & 0.2 & 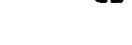 & 100 & - & O & . \\
\hline$\underset{\operatorname{LUN}}{27} \cdots$ & $1>3$ & 9.0 & 80020 & E.UI & 900 & 6.2 & - & 150 & -- & 2.7 & .12 \\
\hline${ }_{\text {oct }}^{13} \cdots$ & 1111 & 14.0 & AnO2n & .02 & 725 & 8.2 & 2.1 & 171 & 210 & - & - \\
\hline 03.... & 1515 & 12.0 & 80020 & $\langle. u|$ & ก00 & 7.3 & - & 1817 & - & $\cdots$ & - \\
\hline
\end{tabular}

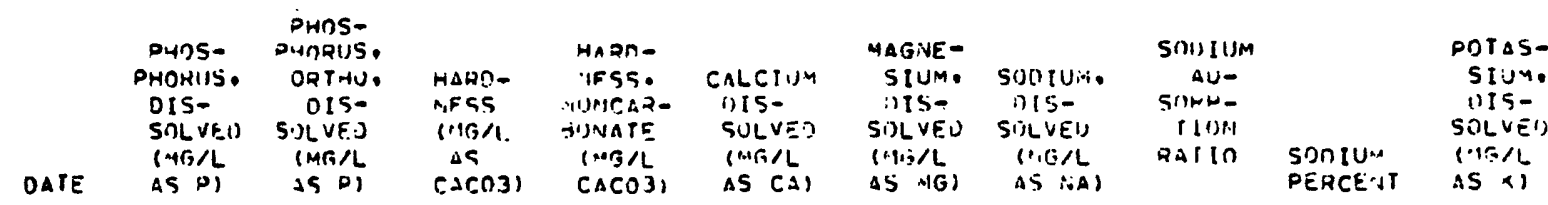

\begin{tabular}{|c|c|c|c|c|c|c|c|c|c|c|}
\hline $\begin{array}{l}\text { JAN } 12 \ldots 79 \\
\text { MAR }\end{array}$ & - n?u & .00 & 411 & $25 n$ & 120 & 26 & 42 & .9 & 19 & 2.4 \\
\hline $\operatorname{JUN}_{\text {JU }}^{27 \ldots . .}$ & .0310 & .04 & 300 & $15 n$ & 64 & 31 & คВ & 2.2 & yy & 2.7 \\
\hline $\operatorname{oct}^{13} \cdots$ & -- & -- & -- & -- & -- & $-\infty$ & - & -- & - & \\
\hline $03 \ldots$ & -- & -- & -- & - & -- & -- & -- & -- & - & \\
\hline
\end{tabular}

\begin{tabular}{|c|c|c|c|c|c|c|c|c|c|c|}
\hline IE & $\begin{array}{l}\text { CHLOD- } \\
\text { OIUE. } \\
\text { OIS- } \\
\text { STLVEO } \\
\text { IIGA } \\
\text { AS CL.) }\end{array}$ & $\begin{array}{c}\text { SULFATE } \\
\text { OIS- } \\
\text { SOLVEU } \\
\text { IMG/L } \\
\text { AS SU4) }\end{array}$ & 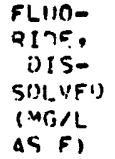 & $\begin{array}{l}\text { SIIICA. } \\
\text { DIS- } \\
\text { SnIVF. } \\
\text { IVG/L } \\
\text { As } \\
\text { sioz, }\end{array}$ & $\begin{array}{l}\text { ARSE:IIC } \\
\text { UIS- } \\
\text { SULUF, } \\
\text { (UG/L } \\
\triangle S \wedge S I\end{array}$ & $\begin{array}{l}\text { AURUN } \\
\text { "SIS- } \\
\text { SOLVEU } \\
\text { (1)G/L } \\
\text { AS } H)\end{array}$ & 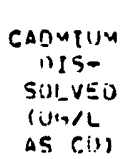 & $\begin{array}{l}\text { CHRO- } \\
\text { "IIIAP } \\
\text { UIS- } \\
\text { SULVFU } \\
\text { (IIG/L } \\
\text { AS CF) }\end{array}$ & 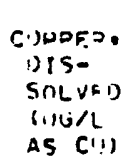 & 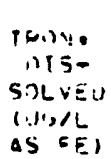 \\
\hline
\end{tabular}

\begin{tabular}{|c|c|c|c|c|c|c|c|c|c|c|}
\hline$\prod_{M \Delta R}^{12 \ldots}$ & 45 & 250 & . $\mathrm{B}$ & 14 & 1 & 1900 & 2 & 0 & 2 & 440 \\
\hline $\operatorname{JuN}^{27 \ldots}$ & 42 & 250 & 1.0 & 11 & $-\infty$ & 1200 & - & $u$ & - & 10 \\
\hline $\operatorname{oct}^{13} \cdots$ & -- & $\infty$ & - & $-\infty$ & $-\infty$ & 1300 & -- & -- & - & +0 \\
\hline 03... & $\cdots$ & $-\infty$ & -- & - & -- & 1100 & $\cdots$ & 10 & - & - \\
\hline
\end{tabular}

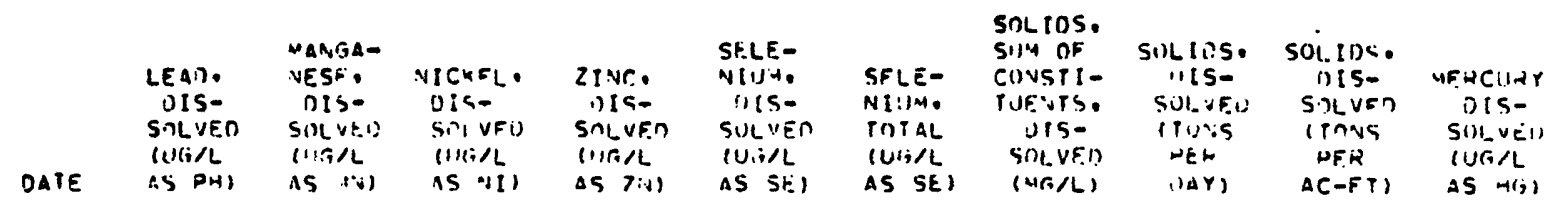

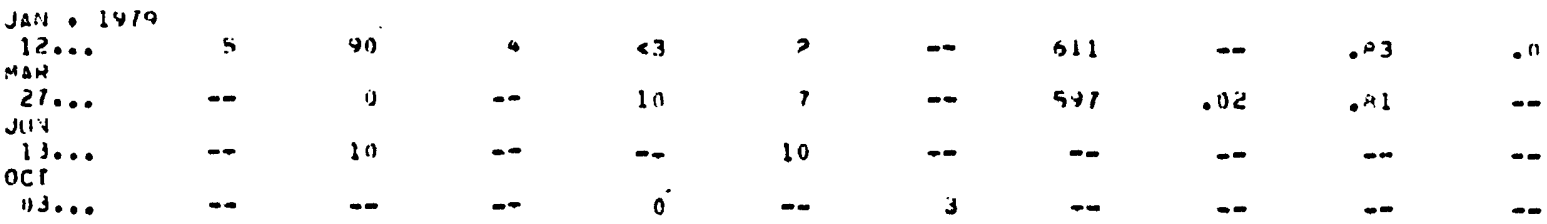


WATER-QUALITY DATA FOR HS SEEP 3, RAYDEN POWERPLANT, HAYDEN, COLO.

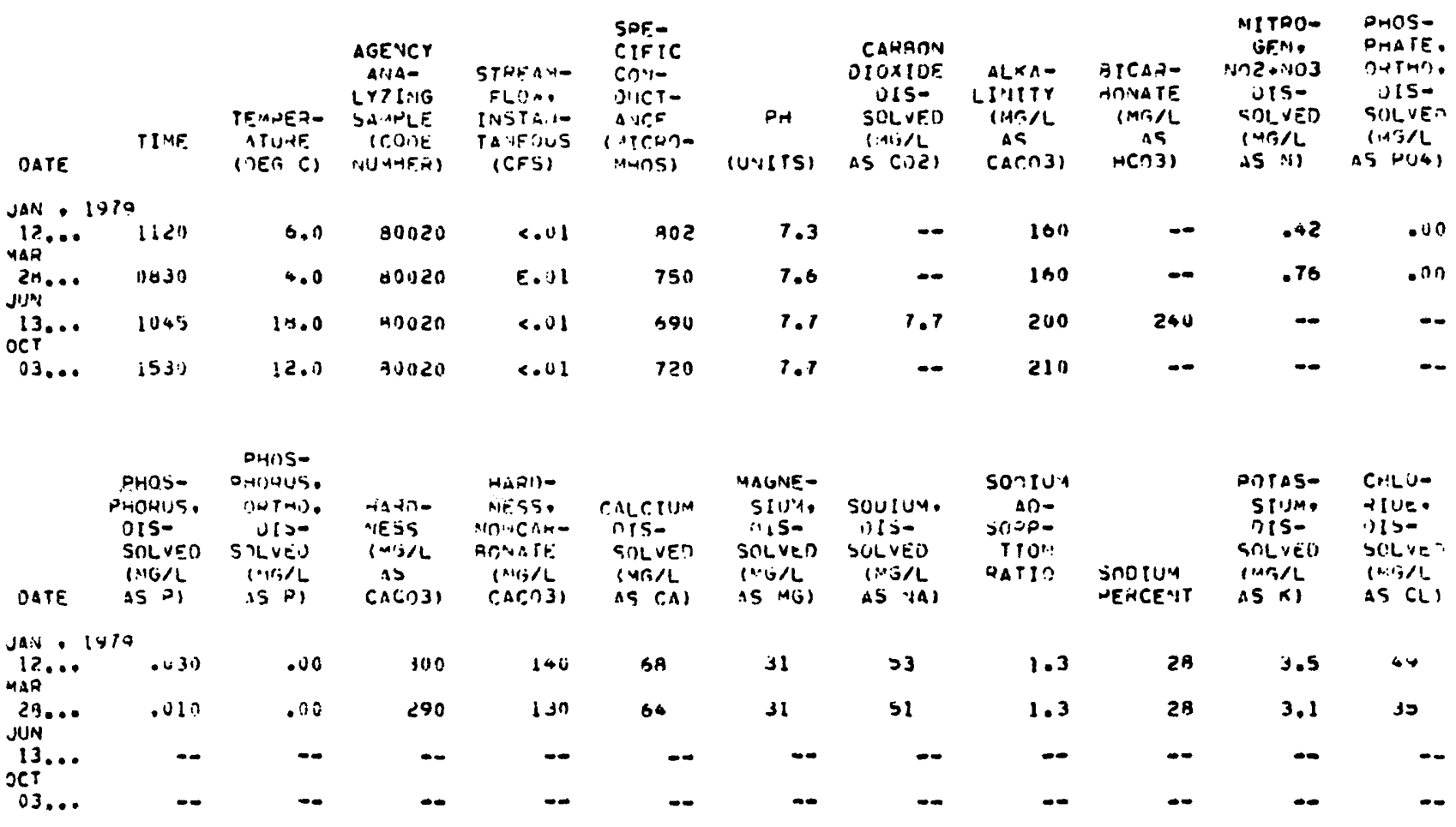

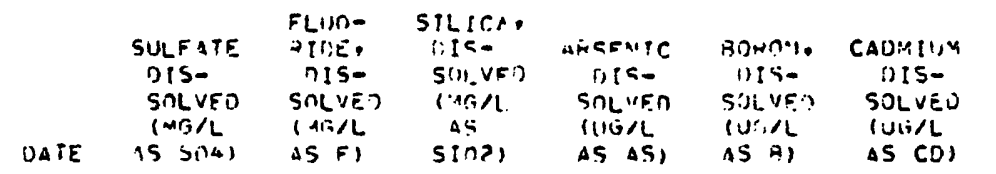
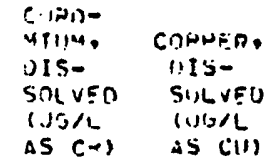

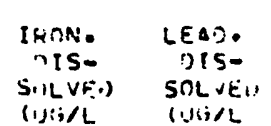

is (iI) ASFE, ISPT)

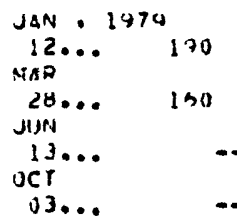

$\begin{array}{lll}.6 & 15 \\ .6 & 11 & - \\ \ldots & \ldots & - \\ -- & \ldots & -\end{array}$

$\begin{array}{rrr}1 & 2300 & 3 \\ -- & 2601 & -- \\ -- & 300 & - \\ -- & 2500 & -\end{array}$

-
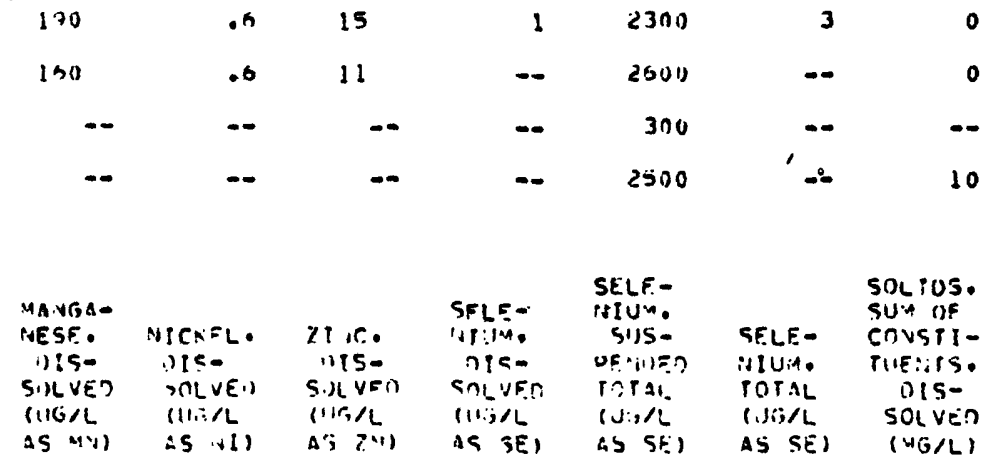

SOLiUS Sut nf

CnvstiTHE:irs olssolven

(WG/L)

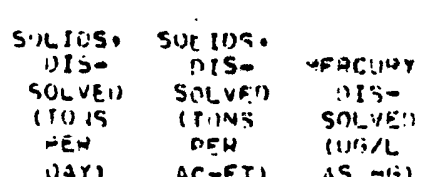

JAN $1+190$

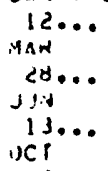

\begin{tabular}{|c|c|c|}
\hline >ง & $\dot{4}$ & $n$ \\
\hline 20 & $-\infty$ & 10 \\
\hline su & $-\infty$ & 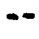 \\
\hline- & -- & $v$ \\
\hline
\end{tabular}

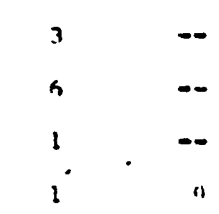


WATER-QUALITY DATA SOR HS SEEP 4, HAYDEN POWERPLANT, HAYDEN, COLO.

\begin{tabular}{|c|c|c|c|c|c|c|c|c|c|c|c|}
\hline DATE & TIME & $\begin{array}{l}\text { TEMDEH- } \\
\text { ATURE } \\
\text { (DET C) }\end{array}$ & $\begin{array}{l}\text { AGENCY } \\
\text { AVA- } \\
\text { LYZING } \\
\text { SATALE } \\
\text { (CUIIE } \\
\text { NUMHEN) }\end{array}$ & 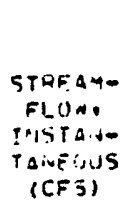 & $\begin{array}{l}\text { SPE- } \\
\text { CIFIC } \\
\text { CDNE } \\
\text { OUSCT- } \\
\text { ANCE } \\
\text { (YICEO- } \\
\text { MHOSI }\end{array}$ & $\begin{array}{c}\text { PH } \\
\text { (:NPIIS) }\end{array}$ & $\begin{array}{c}\text { CAKHON } \\
\text { DIUXIOF } \\
\text { UIS- } \\
\text { SOLVEII } \\
\text { i.1G/L } \\
\text { AS CULI }\end{array}$ & $\begin{array}{l}\text { ALKA- } \\
\text { LINITY } \\
\text { (MT.NL } \\
\text { AS } \\
\text { CACUS) }\end{array}$ & $\begin{array}{c}\text { HICAR- } \\
\text { OONATE } \\
\text { (HONL } \\
\text { AS } \\
\text { HCN3) }\end{array}$ & 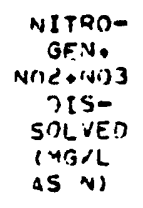 & 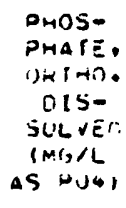 \\
\hline $\begin{array}{l}\text { JAN . I } \\
12 \ldots . .\end{array}$ & $\begin{array}{l}479_{1045} \\
\end{array}$ & 1.0 & $\$ 0020$ & E.10 & 850 & 7.7 & - & 180 & - & 2.1 & .0 .3 \\
\hline $\begin{array}{c}\operatorname{MAR} \\
28 . . .\end{array}$ & 0845 & 3.0 & ENo20 & E.U1 & 770 & 7.5 & -- & 130 & -- & 1.5 & -- \\
\hline ocr $13 .$. & $(1 \cup 3)$ & 17.0 & 40020 & $<.01$ & 725 & 7.8 & 5.8 & 190 & 230 & - & -- \\
\hline $03 \ldots$ & 1525 & 12.0 & BuDZO & E.Ul & 980 & 7.8 & - & 220 & - & -- & $-\infty$ \\
\hline DATE & $\begin{array}{l}\text { PHOS- } \\
\text { PHORUS. } \\
\text { OIS- } \\
\text { SOLVED } \\
\text { (NG/L } \\
\text { AS HI }\end{array}$ & 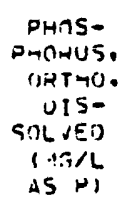 & 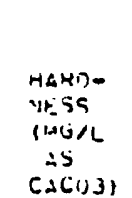 & 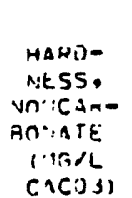 & $\begin{array}{l}\text { CAI.CIUM } \\
\text { 'IS- } \\
\text { SOIVEL } \\
\text { ('AC/L } \\
\text { AS CA) }\end{array}$ & 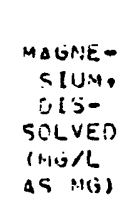 & 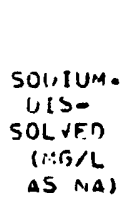 & $\begin{array}{l}\text { SONIUA } \\
\text { AD- } \\
\text { SOCD- } \\
\text { TION: } \\
\text { RATIO }\end{array}$ & $\begin{array}{l}\text { SODIUN } \\
\text { HEHCEVT }\end{array}$ & 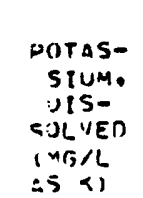 & $\begin{array}{l}\text { CHLUE } \\
\text { HIUE. } \\
\text { HIS- } \\
\text { SULYFA } \\
1: 10 / 6 \\
\text { IS GI. }\end{array}$ \\
\hline
\end{tabular}

\begin{tabular}{|c|c|c|c|c|c|c|c|c|c|c|c|}
\hline $\begin{array}{l}\text { JAN } 1477 \\
12 \ldots\end{array}$ & . Uan & .01 & 290 & 110 & 65 & 31 & 67 & 1.7 & 33 & 2.0 & 35 \\
\hline $\operatorname{JIN}_{\operatorname{liN}}^{28 . .}$ & . 000 & - & 290 & 130 & 67 & 30 & bi & 1.6 & 31 & 2.0 & \$o \\
\hline${ }_{0 r, T}^{13} \ldots$ & - & -- & -- & -- & - & -- & $\cdots$ & $-\infty$ & $-\infty$ & -- & $\cdots$ \\
\hline $03 \ldots$ & $\cdots$ & $-\infty$ & - & - & - & - & $\cdots$ & $\cdots$ & - & - & $\cdots$ \\
\hline
\end{tabular}

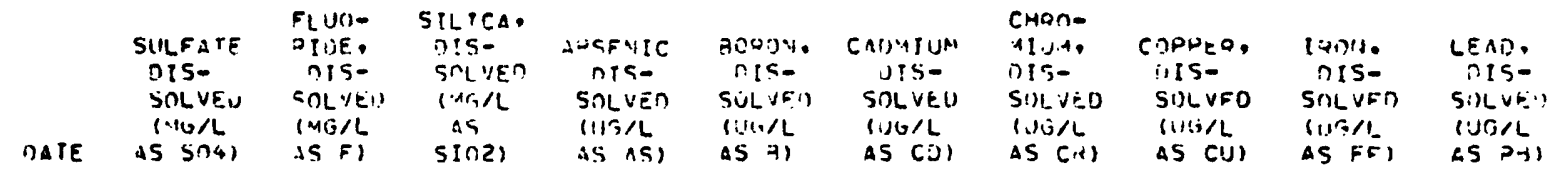

JaY, 1970

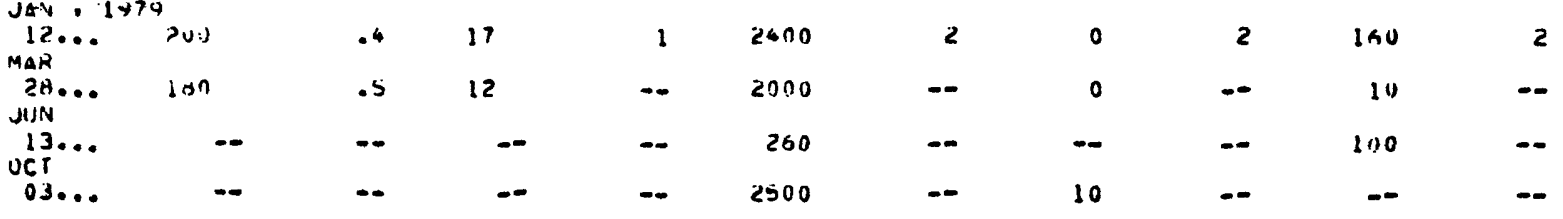

\begin{tabular}{|c|c|c|c|c|c|c|c|c|c|c|}
\hline VATE & $\begin{array}{l}\text { MAVBA- } \\
\text { AESE. } \\
\text { OIS- } \\
\text { SN1.VFi) } \\
\text { (1)(B/L. } \\
\text { AS Hid) }\end{array}$ & $\begin{array}{l}\text { NICKFL, } \\
\text { NIS- } \\
\text { SIULVEU } \\
\text { IISOLL } \\
\text { AS NII }\end{array}$ & 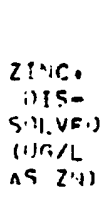 & 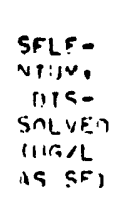 & 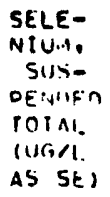 & $\begin{array}{l}\text { SELE- } \\
\text { N(IMM, } \\
\text { POTAL } \\
\text { (UE/L } \\
\text { AS SE) }\end{array}$ & 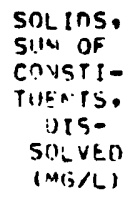 & 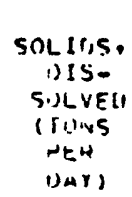 & $\begin{array}{c}\text { SOI. InS } \\
\text { IIS- } \\
\text { SULVFU } \\
\text { ITINS } \\
\text { OEQ } \\
\text { AC-FTI }\end{array}$ & $\begin{array}{l}\text { MECCJAY } \\
\text { IIIS- } \\
\text { SOLVEU } \\
\text { PUTLL } \\
\text { AS RG) }\end{array}$ \\
\hline 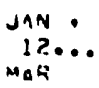 & -0 & 4 & 9 & 0 & $\cdots$ & $\cdots$ & 541 & .15 & .74 & u \\
\hline$\underset{J U N}{2 H} \ldots$ & 10 & - & (1) & 7 & -- & -- & $4 \cos$ & .01 & . nl & $\cdots$ \\
\hline ncis & 40 & - & - & 4 & $\cdots$ & -. & - & - & - & $\cdots$ \\
\hline ..... & -- & - & (1) & 4 & 1 & כ & - & -- & - & $\ldots$ \\
\hline
\end{tabular}


WATER-QUALTTY DATA EOR HS SEEP 5, HAYDEN POWERPLANT, HAYDEN, COLO.

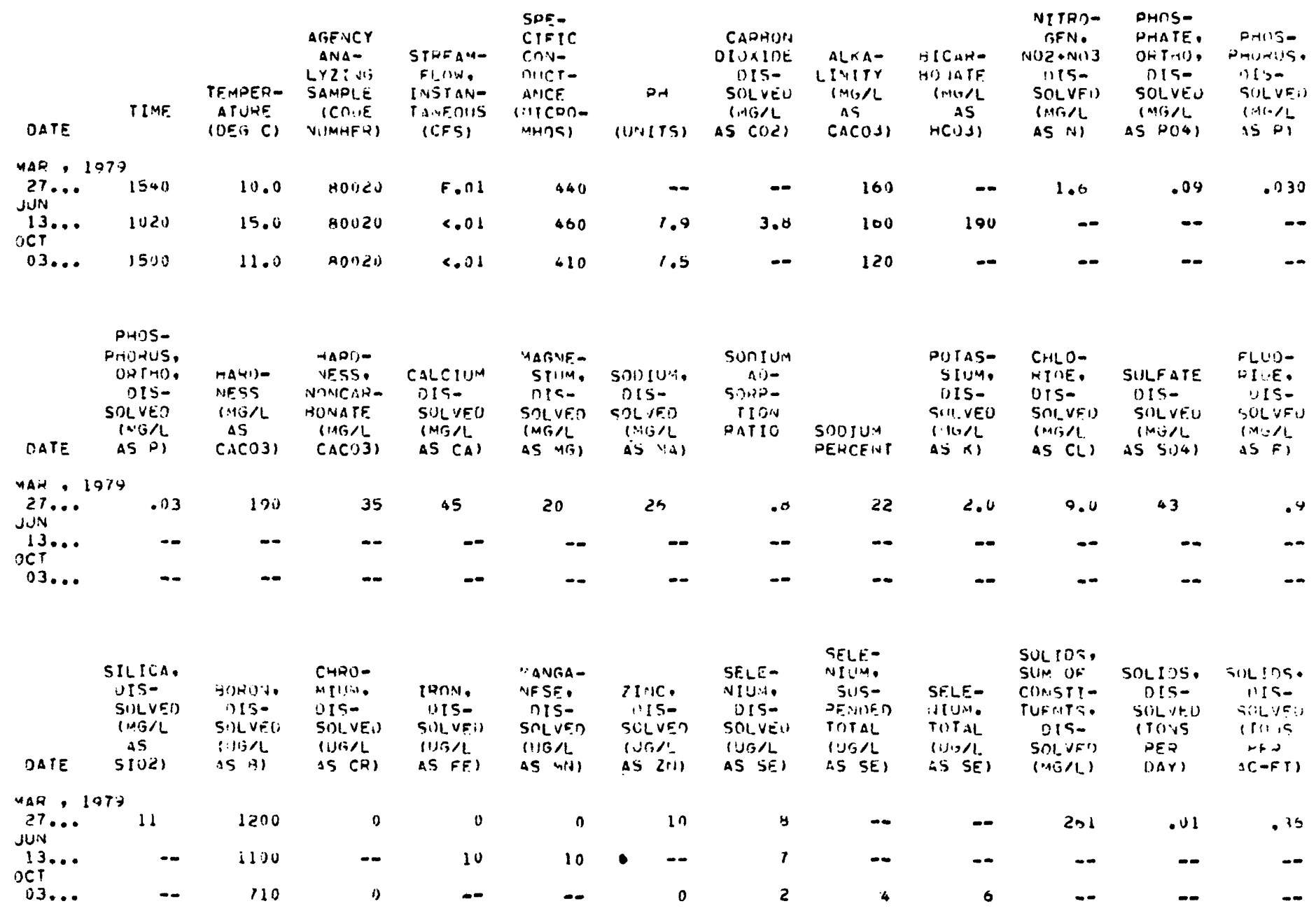


WATER-QUALITY DATA FOR HS SEEP 6, HAYDEN ROWERPLANT, HAYDEN, COLO.

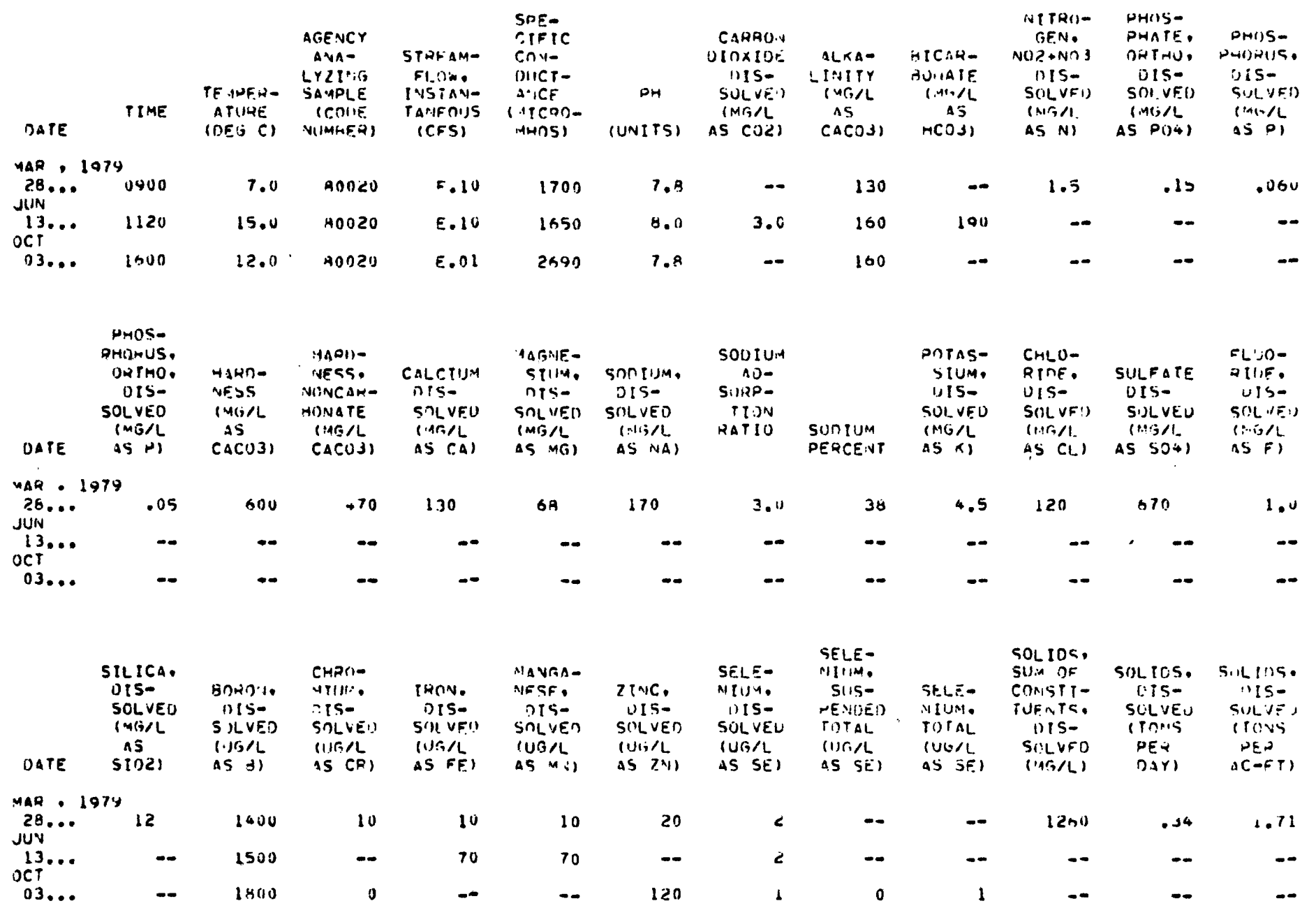


MATER-QUALITY DATA FOR HS SEEP 7, HAYDEN POWERPLANT, HAYDEN, COLO.

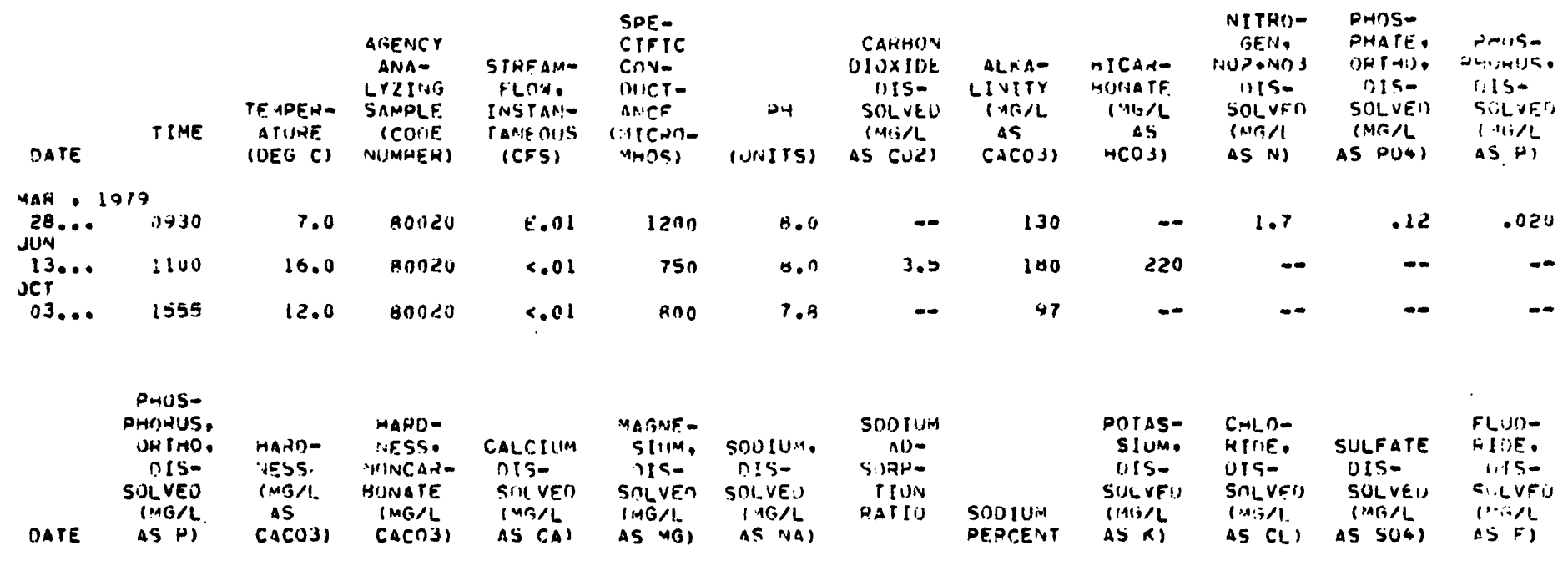

\begin{tabular}{|c|c|c|c|c|c|c|c|c|c|c|c|c|}
\hline${ }_{\text {JUN }}^{28} \ldots$ & .04 & 510 & 380 & 120 & 5? & 58 & 1.3 & 22 & 3.5 & 75 & 410 & 1. \\
\hline${ }_{x<1}^{13 . . .}$ & $-\infty$ & - & - & - & - & - & - & 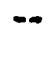 & -- & -- & -- & - \\
\hline $03 \ldots$ & - & - & -- & $-\infty$ & - & - & -- & $\cdots$ & $\infty$ & -- & $\cdots$ & - \\
\hline
\end{tabular}

\begin{tabular}{|c|c|c|c|c|c|c|c|c|c|c|c|}
\hline DATE & $\begin{array}{l}\text { SILICA, } \\
\text { DIS- } \\
\text { SCLVEI) } \\
\text { (MESL } \\
\text { AS } \\
\text { SIOZ) }\end{array}$ & $\begin{array}{l}\text { SORON. } \\
\text { UIS- } \\
\text { SOLVED } \\
\text { (1JG/L } \\
\text { AS D) }\end{array}$ & $\begin{array}{l}\text { EHAN- } \\
\text { AIUHA } \\
\text { UIS- } \\
\text { SNLVEN } \\
\text { (USLL } \\
\text { AS CH) }\end{array}$ & $\begin{array}{l}\text { IRON. } \\
\text { OIS- } \\
\text { SOLVEO } \\
\text { IUTSLL } \\
\text { AS FES }\end{array}$ & $\begin{array}{l}\text { MANFA- } \\
\text { NESSF. } \\
\text { NIS- } \\
\text { SOL VEN } \\
\text { (11G/L } \\
\text { AS VIN) }\end{array}$ & $\begin{array}{l}\text { ZIIC, } \\
\text { OIS- } \\
\text { SOLVE) } \\
\text { (UNAL } \\
\text { AS ZN) }\end{array}$ & $\begin{array}{l}\text { SELF- } \\
\text { IUIU:A. } \\
\text { UIS- } \\
\text { SULVE) } \\
\text { (UU/L } \\
\text { AS SE) }\end{array}$ & $\begin{array}{l}\text { SELE- } \\
\text { PILPMA } \\
\text { POTAL } \\
\text { (WTOLL } \\
\text { AS SE) }\end{array}$ & 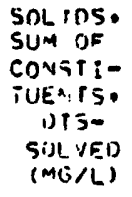 & $\begin{array}{c}\text { SHLIUS. } \\
\text { OIS- } \\
\text { SOIVEO } \\
\text { ITOVS } \\
\text { NER } \\
\text { WAYS }\end{array}$ & $\begin{array}{c}\text { SOLIUS, } \\
\text { JIS- } \\
\text { SULVEN } \\
\text { ITE.S } \\
\text { SER } \\
\text { ACAFII }\end{array}$ \\
\hline $\begin{array}{r}\text { YAR } \\
28 . .\end{array}$ & 79 & 20100 & 0 & 10 & 10 & 20 & 1 & -- & 431 & 02 & 1.17 \\
\hline $\begin{array}{c}\text { JUN } \\
13 \ldots \ldots \\
\text { OCT } \\
03 \ldots \ldots\end{array}$ & -- & 251) & $-\infty$ & 70 & $\begin{array}{l}20 \\
\ldots-\end{array}$ & 70 & -- & -- & - & $-\infty$ & -- \\
\hline
\end{tabular}


WATER-QUALITY DATA FOR HS SEEP 8, HAYDEN POWERPLANT, HAYDEN, COLO.

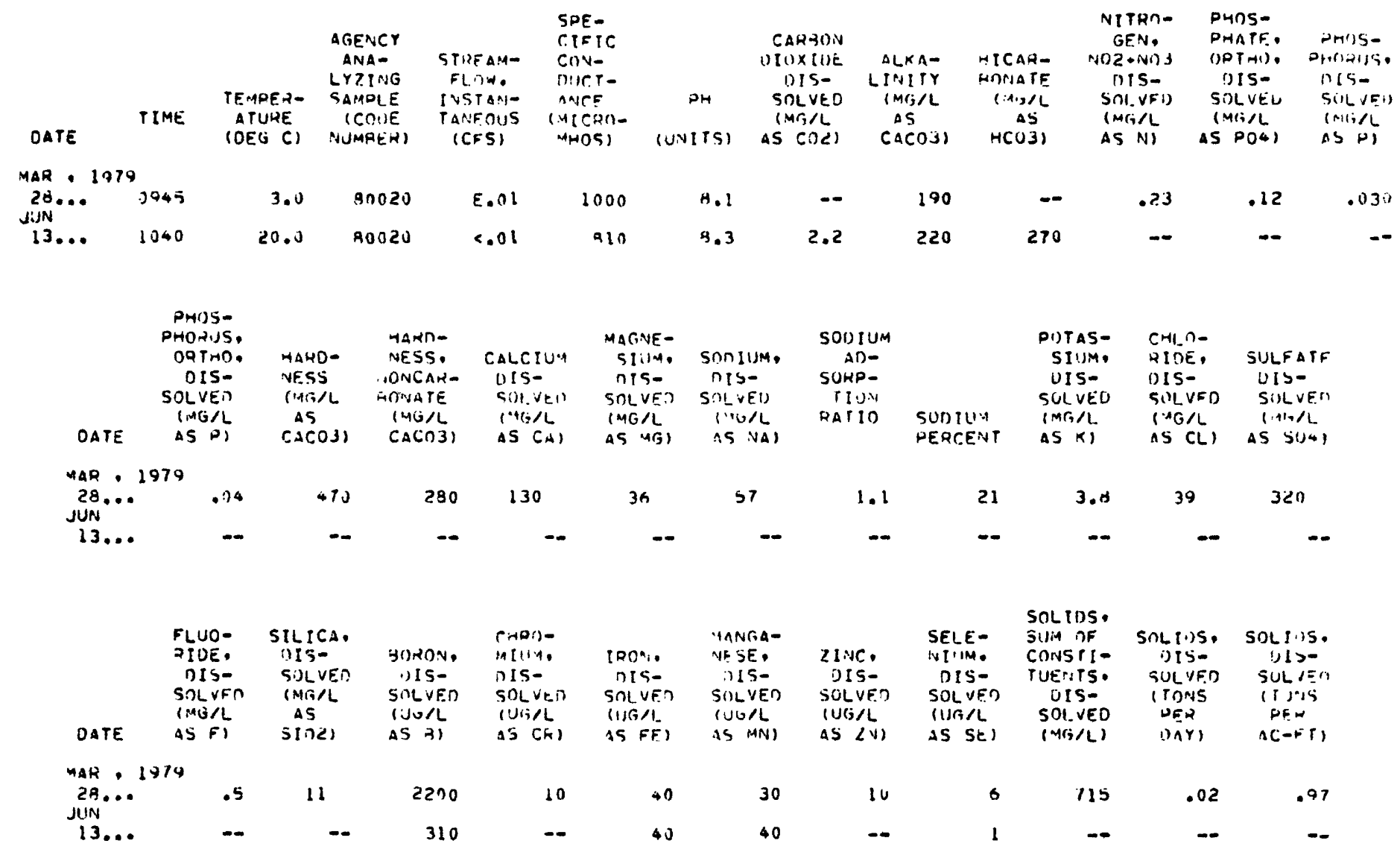


WATER-QUALITY DATA FOR GRAVEL PIT SEEP, HAYDEN POWERPLANT, HAYDEN, COLO.

\begin{tabular}{|c|c|c|c|c|c|c|c|c|c|c|c|}
\hline DATE & TIME & $\begin{array}{l}\text { TENPEH- } \\
\text { ATURE } \\
\text { (DEG C) }\end{array}$ & $\begin{array}{l}\text { AGENCY } \\
\text { ANAD } \\
\text { LYZI IG } \\
\text { SAMLLE } \\
\text { ICUNE } \\
\text { HUMSEHI }\end{array}$ & 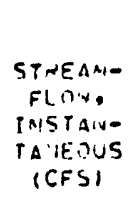 & $\begin{array}{l}\text { SPE- } \\
\text { CIFIC } \\
\text { CON- } \\
\text { NUCT- } \\
\text { ANCE } \\
\text { (MICUO- } \\
\text { MHOS) }\end{array}$ & $\begin{array}{c}P H \\
(1) \cdot(r S)\end{array}$ & $\begin{array}{l}\text { CARAON } \\
\text { DIUXIDE } \\
\text { UIS- } \\
\text { SULVEU } \\
\text { (MSRL } \\
\text { AS COL) }\end{array}$ & $\begin{array}{l}\text { ALRA- } \\
\text { LUVTYY } \\
\text { IAASIL } \\
\text { AE } \\
\text { CACOS) }\end{array}$ & 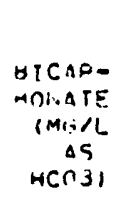 & 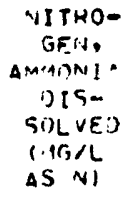 & 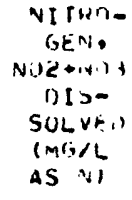 \\
\hline \multicolumn{12}{|c|}{ JAN , 1774} \\
\hline YAR $11 .$. & 1445 & - & $80 n 20$ & -- & 436 & 6.9 & $-\infty$ & 150 & - & .05 & - ns \\
\hline $\operatorname{JUN}_{\text {JUN }}^{27 . .}$ & 1431 & 11.0 & 80020 & -- & 440 & 8.0 & - & 150 & -- & $\cdots$ & .13 \\
\hline${ }_{\text {oC }}^{33} \cdots$ & 0920 & 10.0 & Bunzo & S.US & 400 & 7.6 & 7.2 & 150 & 180 & $\cdots$ & - \\
\hline $02 \ldots$ & 15311 & 11.0 & Hov20 & E.US & 436 & 7.5 & -- & 100 & - & -- & $\cdots$ \\
\hline OATE & $\begin{array}{l}\text { PHOS- } \\
\text { PHATF, } \\
\text { URTHS, } \\
\text { OIS- } \\
\text { SNLVFI } \\
\text { (M'SAL } \\
\text { AS PIS+) }\end{array}$ & $\begin{array}{l}\text { PAOSO- } \\
\text { PHIINUS. } \\
\text { OIS- } \\
\text { SULVED } \\
\text { (*SGL } \\
\text { AS P) }\end{array}$ & 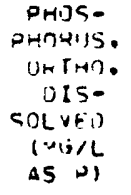 & $\begin{array}{l}\text { HAOD- } \\
\text { NESS } \\
\text { (M(A)L } \\
\triangle S S \\
C A C(1) 3)\end{array}$ & 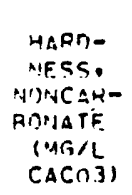 & $\begin{array}{l}\text { CALCIUM } \\
\text { OIS- } \\
\text { SOLVEN } \\
\text { IYG/L } \\
\text { AS } \\
\text { CALOSI }\end{array}$ & $\begin{array}{l}\text { CALCIUA } \\
\text { UIS- } \\
\text { SULVED } \\
\text { (:ATIII } \\
\text { AS CA) }\end{array}$ & $\begin{array}{l}\text { MARNE- } \\
\text { SIUND. } \\
\text { DIS- } \\
\text { SI)!VEO } \\
\text { (MR/L } \\
\text { AS M(i) }\end{array}$ & 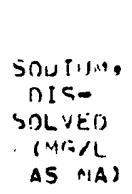 & $\begin{array}{c}\text { SONTUM } \\
\text { An- } \\
\text { GONO- } \\
\text { TEON } \\
\text { WATIOS }\end{array}$ & $\begin{array}{l}\text { SUIIU. } \\
\text { PEHCE 'T }\end{array}$ \\
\hline$\underset{\operatorname{JAN}}{\operatorname{JAR} \ldots 1}$ & .74 & $\cdot 3 \nrightarrow 0$ & .24 & (61) & 13 & 44 & 94 & 13 & 22 & •A & $2 \bar{z}$ \\
\hline $\operatorname{JUN}_{\text {JUN }}^{27 . .}$ & .03 & .010 & .01 & 190 & 37 & - & su & 15 & 22 & .7 & 2.1 \\
\hline • & $\cdots$ & -- & -- & $\cdots$ & -- & $\cdots$ & $\cdots$ & - & - & - & - \\
\hline $02 \ldots$ & -- & $\cdots$ & $=$ & $\cdots$ & $\cdots$ & $\cdots$ & $\cdots$ & -- & - & - & - \\
\hline
\end{tabular}

\begin{tabular}{|c|c|c|c|c|c|c|c|c|c|c|c|}
\hline & $\begin{array}{l}\text { POTAS- } \\
\text { SIUM, } \\
\text { OIS- } \\
\text { SOLVEA } \\
\text { IMGIL }\end{array}$ & $\begin{array}{l}\text { CHIOO } \\
\text { PIUE. } \\
\text { PIS- } \\
\text { SOLVEO } \\
\text { IMIVIL }\end{array}$ & $\begin{array}{l}\text { SULFATF } \\
\text { OIj- } \\
\text { SULVEO } \\
\text { (ACIL }\end{array}$ & $\begin{array}{l}\text { FLUU- } \\
\text { OIDE, } \\
\text { OIS- } \\
\text { SIUL\%ES } \\
\text { (IARAL }\end{array}$ & $\begin{array}{c}\text { SILICA, } \\
\text { OIS- } \\
\text { SOLVEO } \\
\text { IUFAL } \\
\text { AS }\end{array}$ & $\begin{array}{c}\text { ARSENIC } \\
\text { UIS- } \\
\text { SILVEU } \\
\text { UUU/L }\end{array}$ & $\begin{array}{l}\text { BUHON, } \\
\text { UIS- } \\
\text { SUL JES } \\
\text { IUG/L }\end{array}$ & $\begin{array}{c}\text { CAnALUA } \\
\text { nIS- } \\
\text { SOLJEO } \\
\text { (11:AL }\end{array}$ & 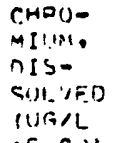 & $\begin{array}{l}\text { CIPPFR, } \\
\text { TIS- } \\
\text { SIULEOI } \\
\text { IUS/L }\end{array}$ & 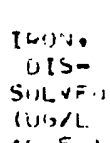 \\
\hline ITE & $\Delta S K I$ & AS (L) & as $S(14)$ & $\triangle S F I$ & $5[021$ & AS ASI & As dा & $\triangle S C O l$ & AS (R) & as Cul & As Fr.l \\
\hline
\end{tabular}
Jair 1979

\begin{tabular}{|c|c|c|c|c|c|c|c|c|c|c|}
\hline MAK $11 .$. & 3.0 & 9.1 & 46 & .5 & 15 & 1 & 1700 & 3 & 0 & 0 \\
\hline $27 \ldots$ & 3.1 & 17 & SB & .5 & 6.3 & $-\infty$ & 1100 & -- & 0 & -- \\
\hline OCT & -- & $=$ & - & $-\infty$ & $-\infty$ & - & 1200 & $\cdots$ & $\cdots$ & - \\
\hline $02 \ldots$ & -- & $\cdots$ & -- & -- & - & -- & 950 & -- & 10 & $\cdots$ \\
\hline
\end{tabular}

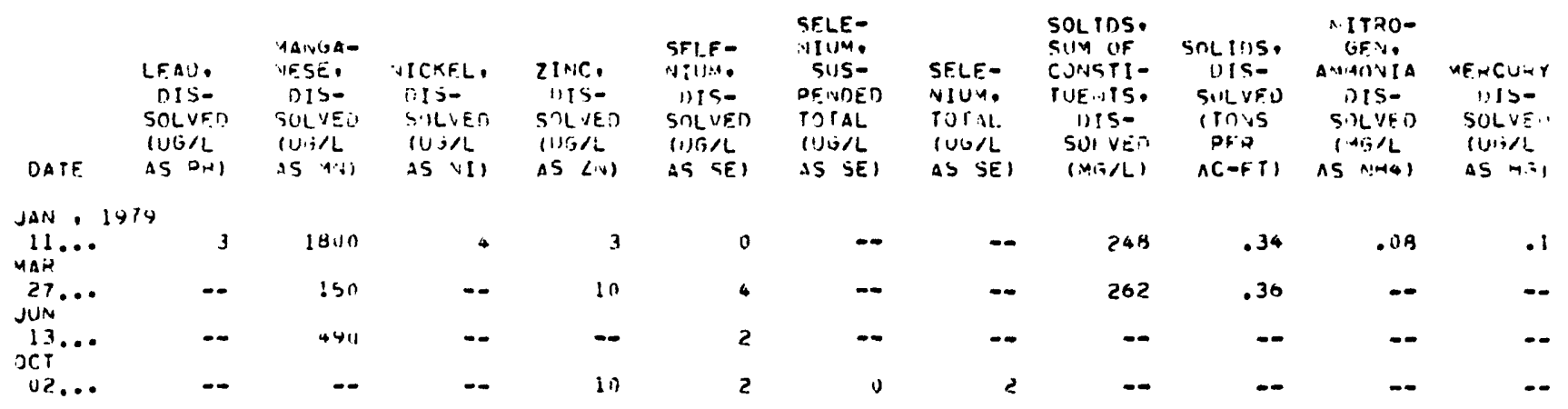




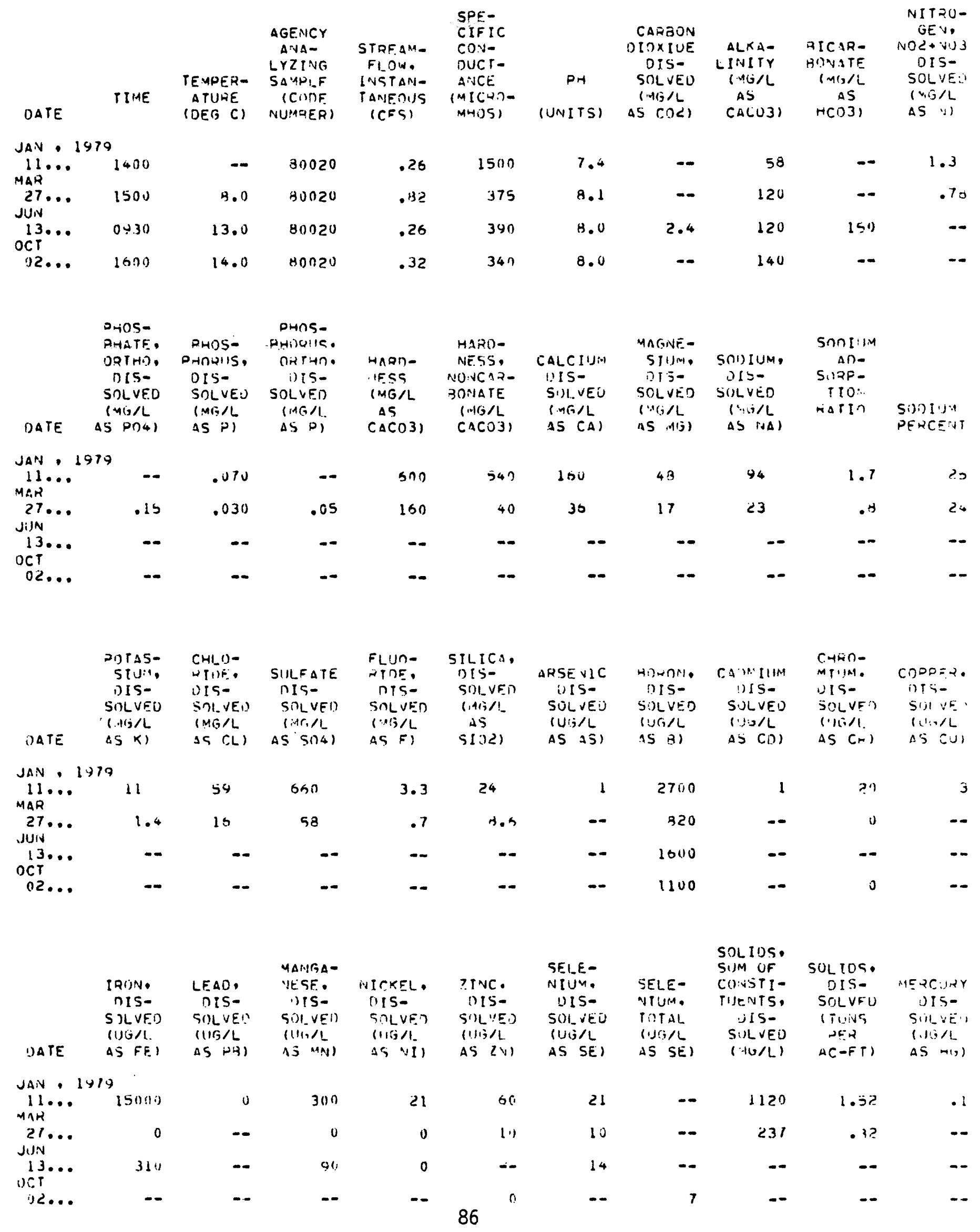


WATER-QUALITY DATA FOR SAGE CREEK ABOVE HAYDEN POWERPLANT, HAYDEN, COLO.

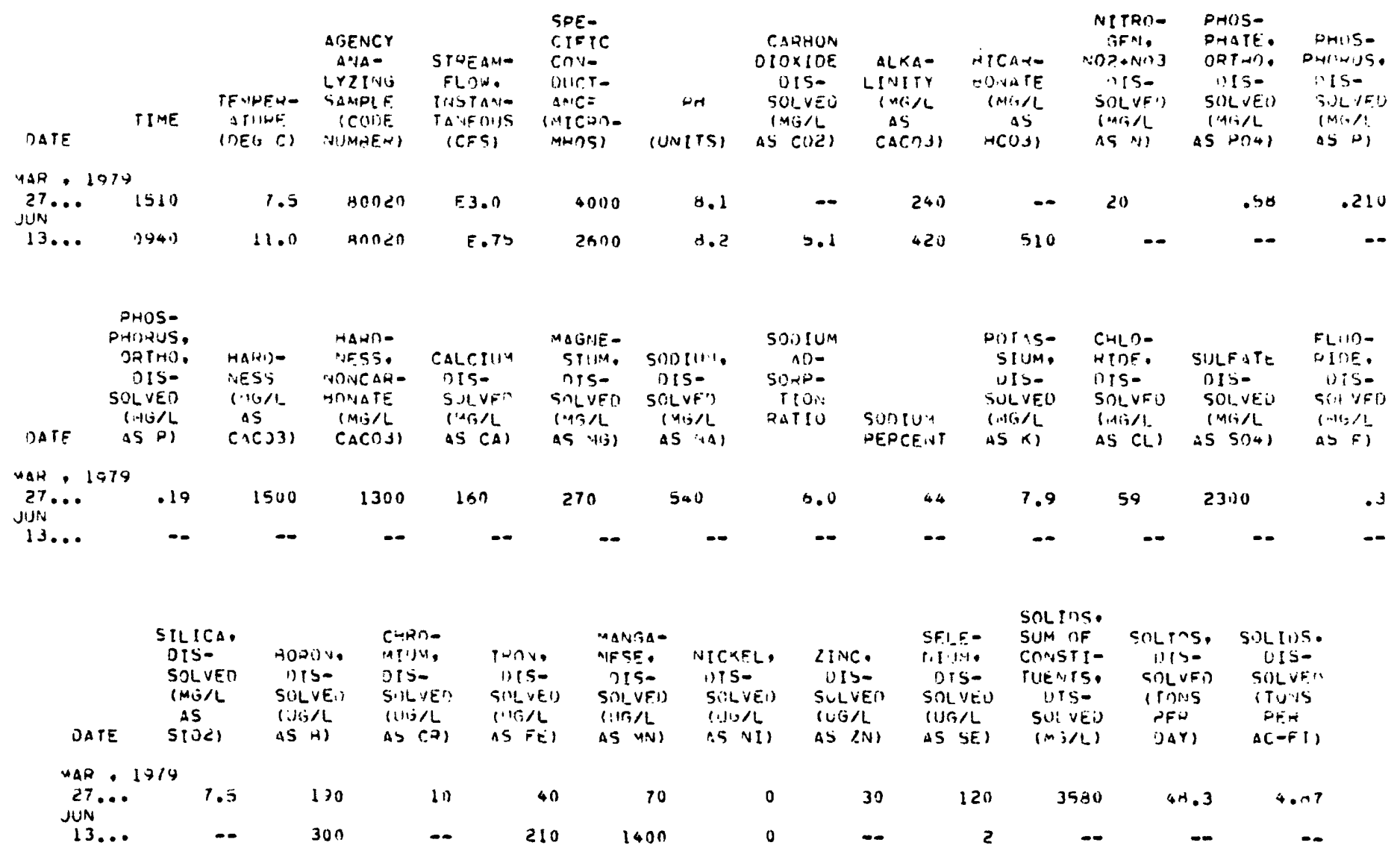


WATER-QUALITY DATA FOR SAGE CREEK AT O.S. HIGHWAY 40, HAYDEN, COLO.

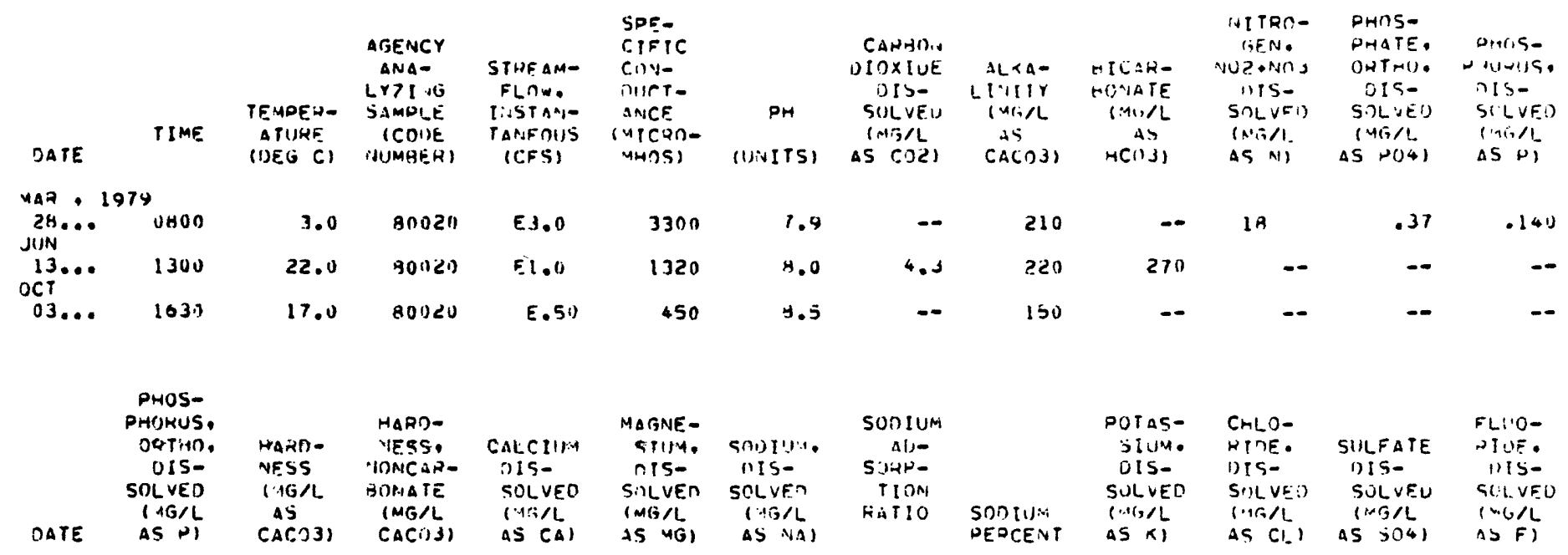

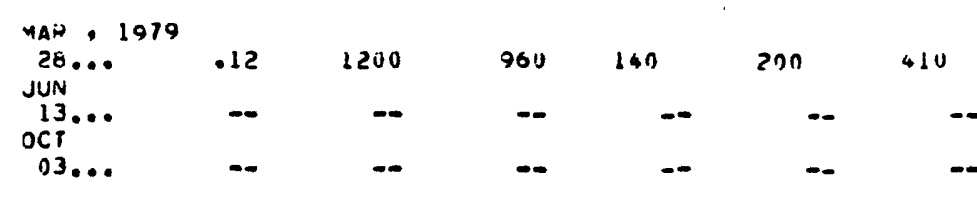

\begin{tabular}{|c|c|c|c|c|c|c|c|c|c|c|c|}
\hline DATE & $\begin{array}{l}\text { SILICA, } \\
\text { OIS- } \\
\text { SOLVEO } \\
\text { (MG/L } \\
\text { AS } \\
\text { SIOC) }\end{array}$ & $\begin{array}{l}\text { HURDV. } \\
\text { DIS- } \\
\text { SULVEO } \\
\text { (UT,/L } \\
\text { IS d) }\end{array}$ & $\begin{array}{l}\text { CHWO- } \\
\text { YIJM, } \\
U ! S- \\
\text { SOLVFI) } \\
(1 J(j / L \\
\text { AS CRI }\end{array}$ & $\begin{array}{l}\text { PRIN } \\
\text { IIS- } \\
\text { SULVEO } \\
\text { (IIG/L } \\
\text { AS FE) }\end{array}$ & $\begin{array}{l}\text { YANGA- } \\
\text { NFSE. } \\
\text { OIS- } \\
\text { SOLVFD } \\
\text { CJG/I. } \\
\text { AS YNII }\end{array}$ & $\begin{array}{l}\text { IICKEL, } \\
\text { DIS- } \\
\text { SIULVES } \\
\text { (1U/L } \\
\text { HS VII }\end{array}$ & $\begin{array}{l}\text { ZIVCE, } \\
\text { JIS- } \\
\text { SOLVED } \\
\text { (UIS/L } \\
\text { AS } L: V)\end{array}$ & 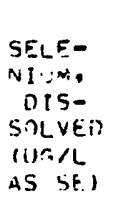 & 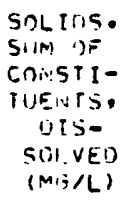 & 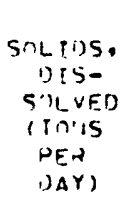 & 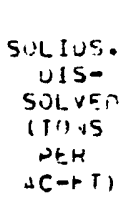 \\
\hline$\underset{\text { JUN }}{2 R} \cdot \underset{1}{M A R}$ & 6.9 & 200 & 10 & 40 & 60 & 0 & 20 & 110 & $2+20$ & 22.8 & 3.74 \\
\hline oct $13 \ldots$ & -- & 570 & -- & 100 & 210 & - & - & 4 & -- & -- & -- \\
\hline $03 \ldots$ & $\therefore$ & 130 & D & - & - & - & 70 & - & 90 & -- & .12 \\
\hline
\end{tabular}


WATER-QUALITY DATA FOR YAMPA RIVER NEAR HAYDEN, COLO.

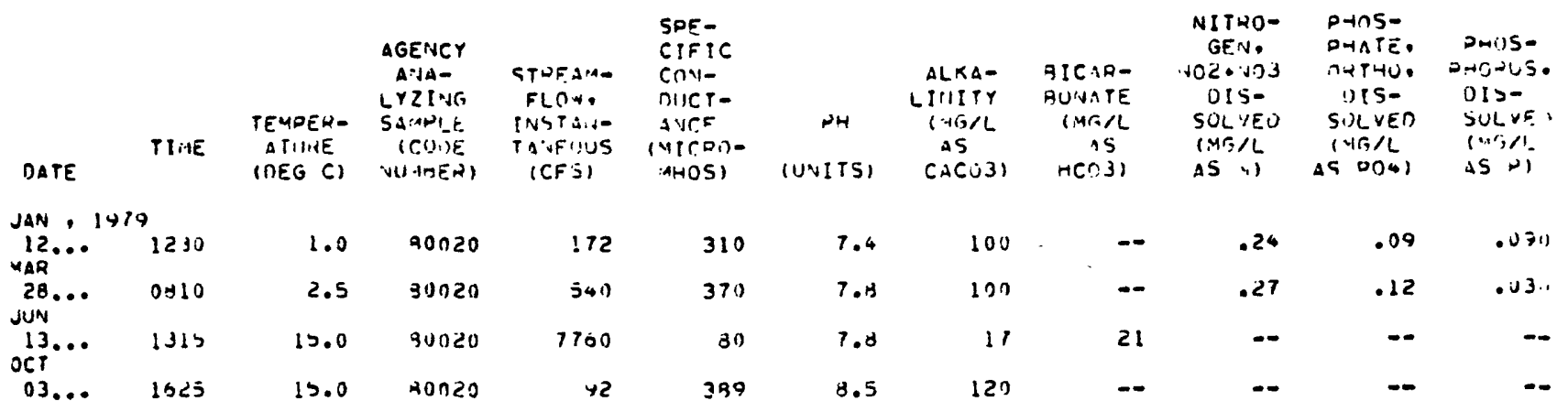
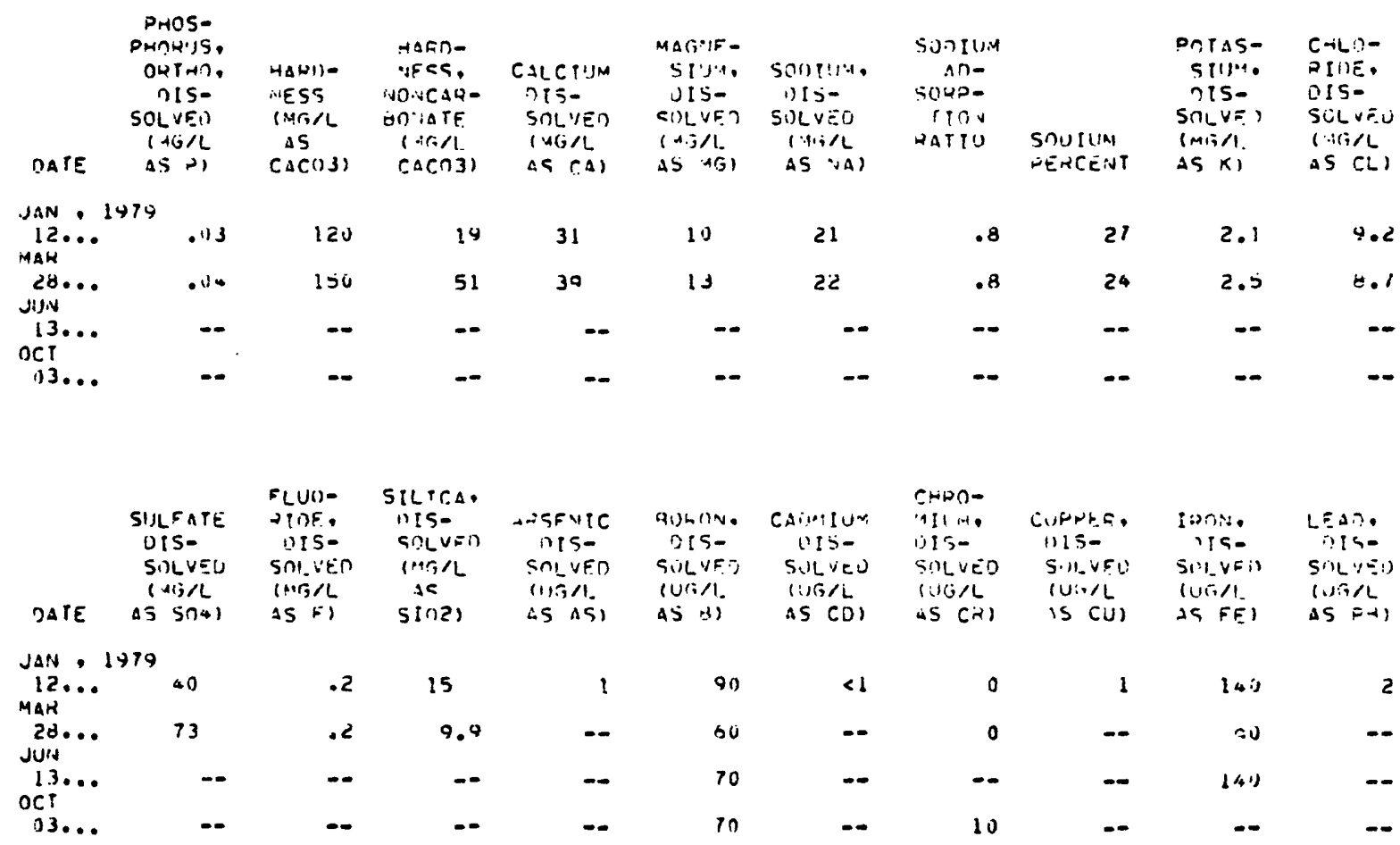

0
0
10
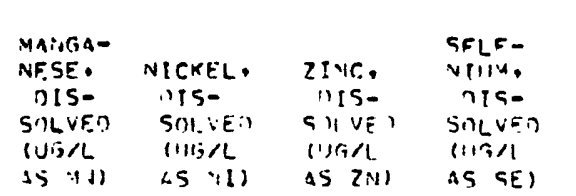

SELE-

जIII.

orintifon

TOIAL

(1), 1 ,

AS TEI

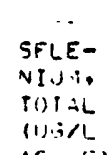

SFLE-

NI, in

AS $D E$.
SOLIOS.

Silin ist

c) ivit -

TUF.VTS,

ils-

STLVE:

$(M, j / L)$
SILINE. SUL. IDS

ilis- it

SLLVEL SOLVEI)

Sth (tidive SOLVE.

(IIC,

Jav. 1,10

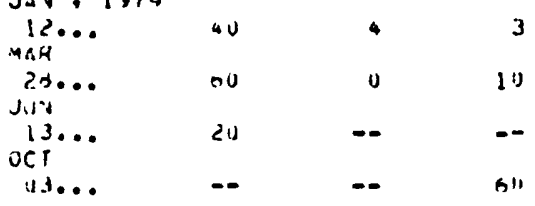


WATER-QUALITY DATA FOR YAMPA RIVER AT HAYDEN, COLO.

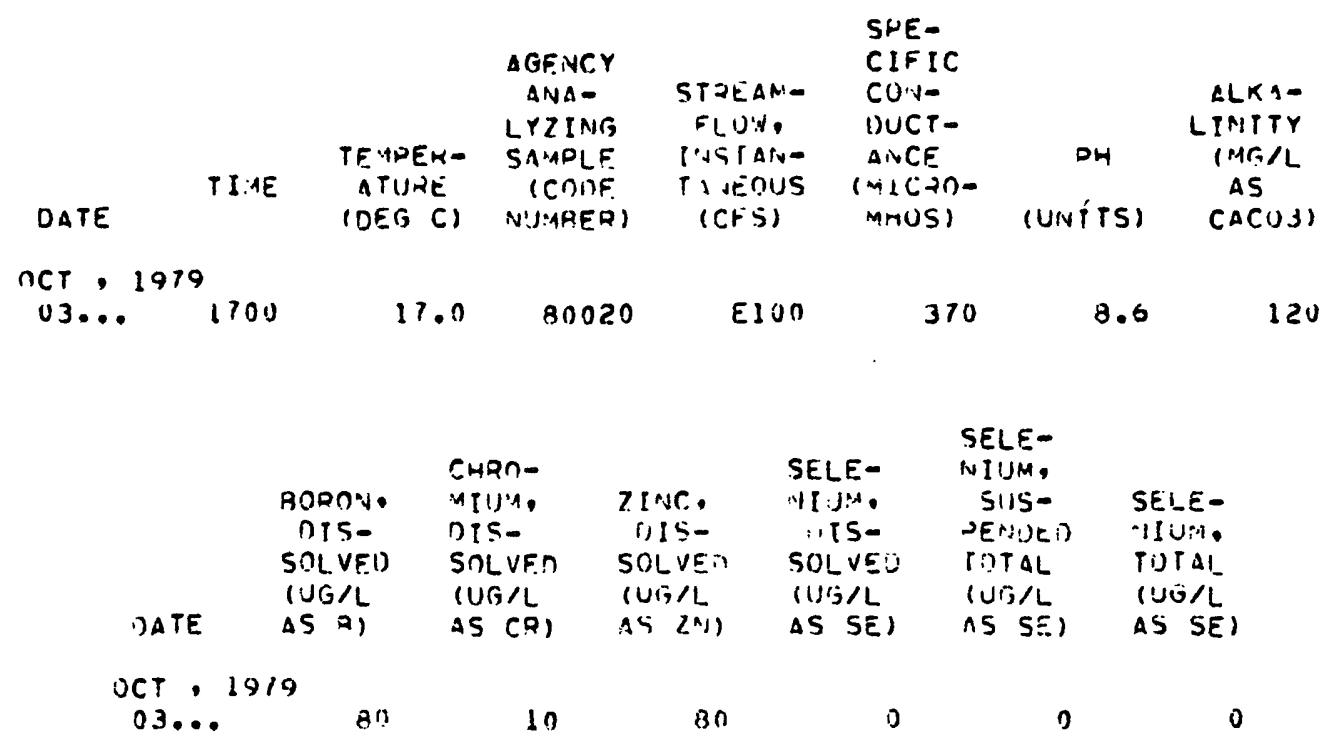

* U. S. GOVERMEENT PRINTING OFFICE 1982 - r 